\title{
NGNP Infrastructure Readiness Assessment: Consolidation Report
}

\author{
Brian K. Castle
}

February 2011
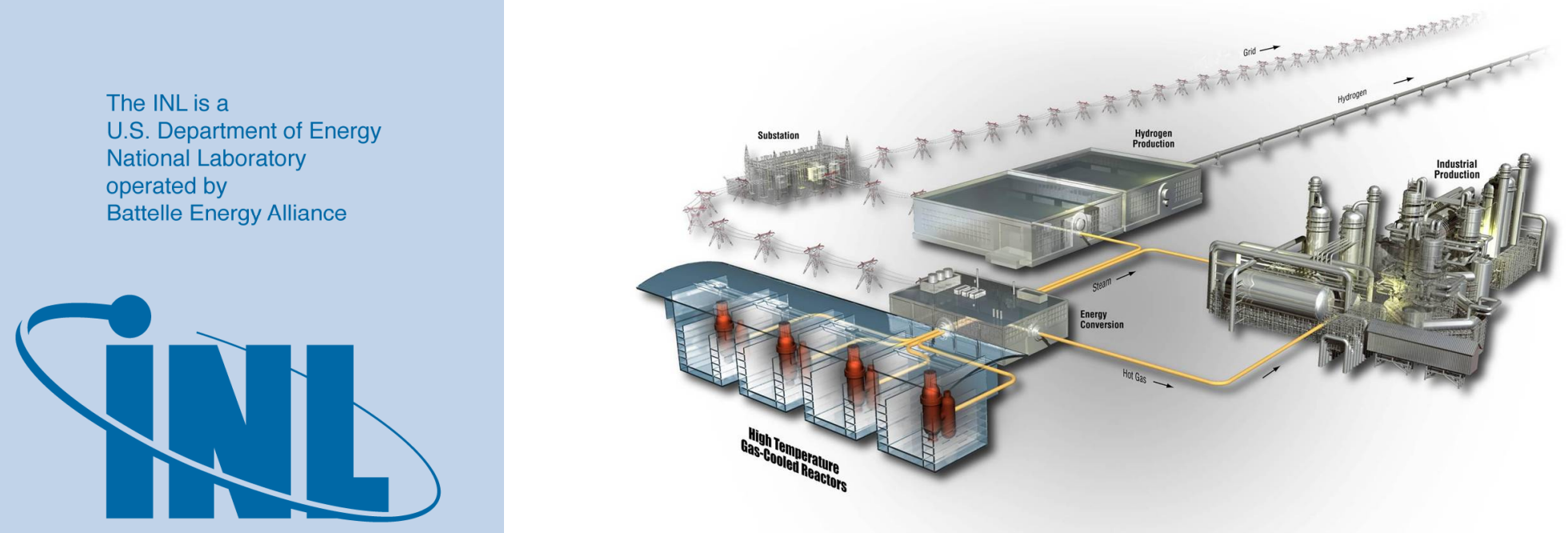

Idaho National Laboratory 


\section{DISCLAIMER}

This information was prepared as an account of work sponsored by an agency of the U.S. Government. Neither the U.S. Government nor any agency thereof, nor any of their employees, makes any warranty, expressed or implied, or assumes any legal liability or responsibility for the accuracy, completeness, or usefulness, of any information, apparatus, product, or process disclosed, or represents that its use would not infringe privately owned rights. References herein to any specific commercial product, process, or service by trade name, trade mark, manufacturer, or otherwise, does not necessarily constitute or imply its endorsement, recommendation, or favoring by the U.S. Government or any agency thereof. The views and opinions of authors expressed herein do not necessarily state or reflect those of the U.S. Government or any agency thereof. 


\title{
NGNP Infrastructure Readiness Assessment: Consolidation Report
}

\author{
Brian K. Castle
}

February 2011

Idaho National Laboratory Next Generation Nuclear Plant Project Idaho Falls, Idaho 83415

Prepared for the

U.S. Department of Energy

Office of Nuclear Energy

Under DOE Idaho Operations Office

Contract DE-AC07-05ID14517 



\title{
Next Generation Nuclear Plant Project
}

\section{NGNP Infrastructure Readiness Assessment: Consolidation Report}

\author{
INL/EXT-11-20973
}

February 2011
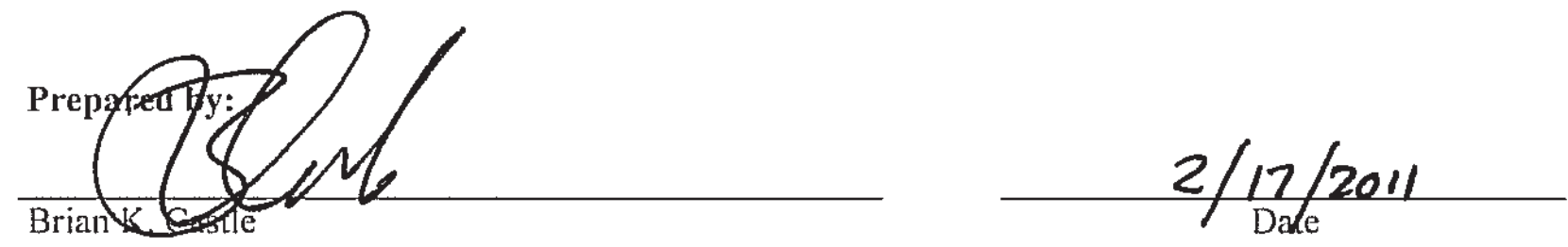

Author

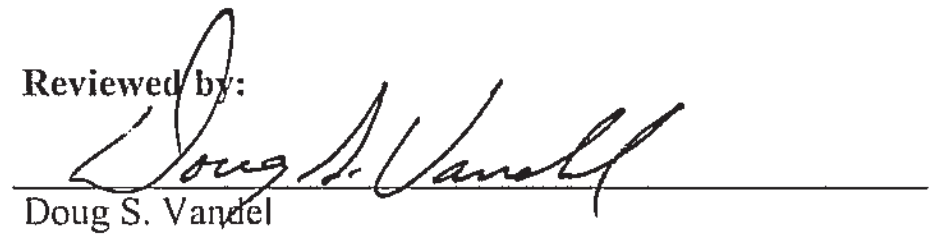

NGNP Engineering Lead
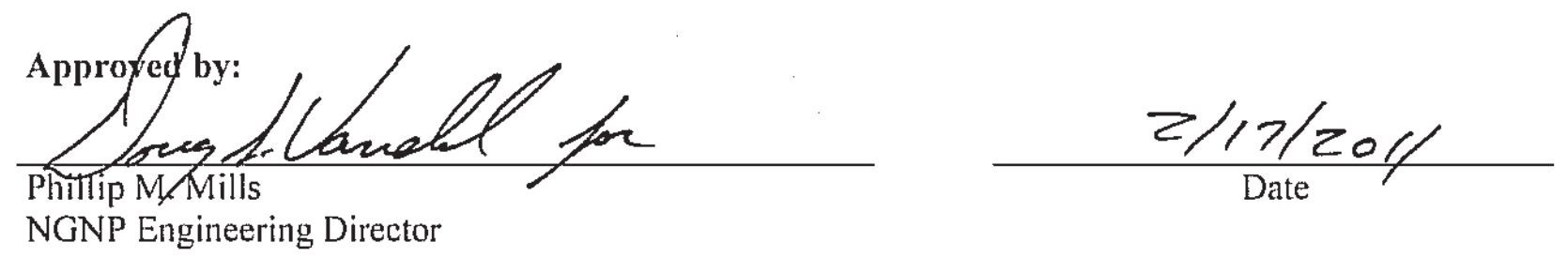



\section{SUMMARY}

Current industry capability was assessed to support deployment of the firstof-a-kind (FOAK) high temperature gas-cooled reactor (HTGR) to be developed and demonstrated by the Next Generation Nuclear Plant (NGNP) Project, assuming an operational date of +2020 timeframe. The goals of this infrastructure readiness assessment were to assess current infrastructure capabilities, identify development needs, and recommend improvements to support the deployment of the FOAK plant, with an understanding that the same infrastructure could be brought to bear on follow-on HTGR deployment. AREVA and Westinghouse were chosen to perform independent assessments of industry's capabilities because of their experience with nuclear supply chains supporting the EPR and AP-1000 reactors. Both suppliers produced infrastructure readiness assessment reports that identified key components and capabilities and categorized them into three groups based on industry's ability to produce the necessary components or possess the required skills to produce a FOAK plant. The NGNP Project also provided input for those areas where project-led programs, such as fuel and graphite qualification programs, have applicable information concerning industrial capabilities.

Most of the components and topics were determined to either have no significant issues preventing deployment in the FOAK plant or to be obtainable with advanced planning. Two components identified as requiring significant technical and-or qualification development were the hot gas duct and the tristructural-isotropic (TRISO) fuel.

AREVA did not comment on the readiness of the TRISO fuel because they relied on the Advance Gas Reactor (AGR) Fuel Development and Qualification Program, which is being addressed by the NGNP Project. Westinghouse previously had relied on a fuels program led by the Pebble Bed Modular Reactor (PBMR) project, which is not currently viable, and commented on the availability of fuel in the infrastructure readiness assessment to ensure that pebble bed fuel was addressed. Westinghouse specifically identified two separate areas they believe need development: completing the fuel qualification program, and addressing fuel manufacturing capabilities. The NGNP Project concurs with Westinghouse's assessment and has a program in place that specifically addresses these and other areas.

A discrepancy exists between suppliers' and the NGNP Project's assessments of core ceramic structures. The two suppliers state that producing nuclear grade graphite would not present any significant problems that would prohibit or delay deployment in the FOAK plant. The NGNP Project believes that significant development is needed before the production of nuclear grade graphite is mature enough to meet the FOAK plant requirements. The NGNP Project has identified several areas of nuclear grade graphite production that need a dedicated program to facilitate the required development. There is a significant competition for high purity isotropic cokes that will require advanced planning to ensure a timely delivery. Fuel and reflector blocks will also need significant machining in a facility qualified by the American Society of Mechanical Engineers (ASME). The NGNP Graphite Development and Qualification Program is expecting responsibility for the qualification program to certify graphite vendors may be an issue. 
The final conclusion of this consolidation report is that there is sufficient infrastructure in place with advanced planning to deploy the FOAK plant. It has been determined that the NGNP design must be matured in order to place advanced orders for long-lead-time components. Many of these components are large forgings and this industry has limited capacity for producing very large forgings. There is a risk that unless orders for FOAK components are placed early, upcoming LWR construction projects could cause backlogs in delivery schedules, resulting in schedule delays. 


\section{CONTENTS}

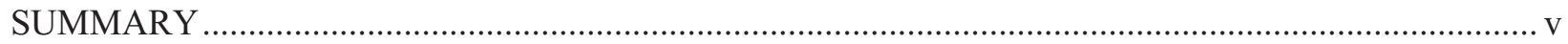

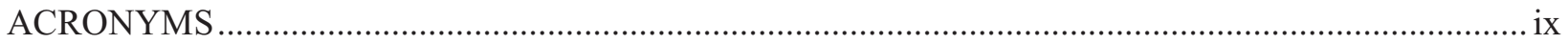

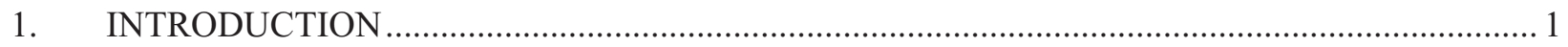

2. INFRASTRUCTURE READINESS FOR FOAK PLANT COMPONENTS …........................... 2

2.1 Infrastructure Component Descriptions and Categorizations .............................................. 2

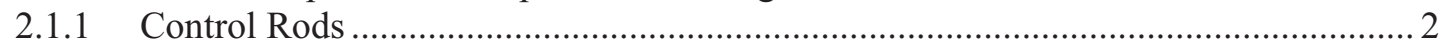

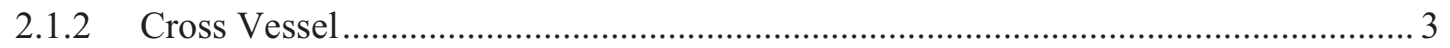

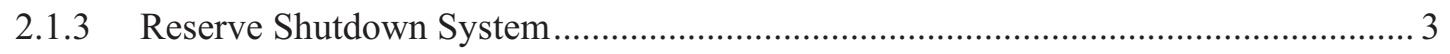

2.1.4 Rankine Cycle Power Conversion System.............................................................. 3

2.1.5 Core Ceramic Structures - Graphite Blocks ....................................................... 4

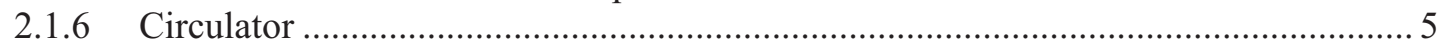

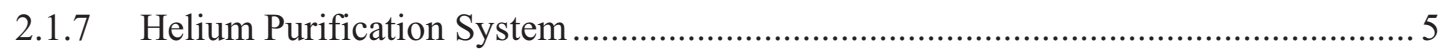

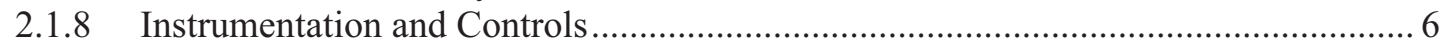

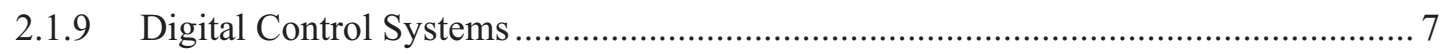

2.1.10 Composite Materials - Core Structures …............................................................ 7

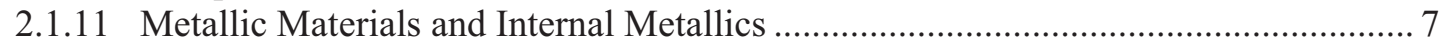

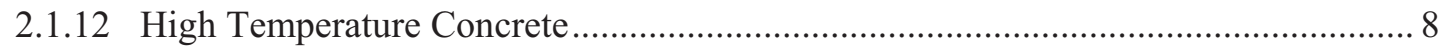

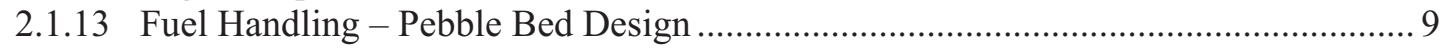

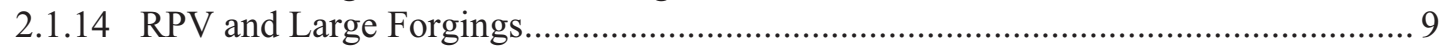

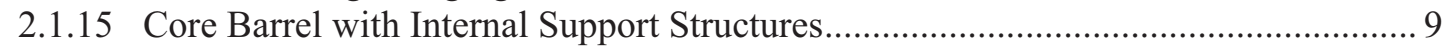

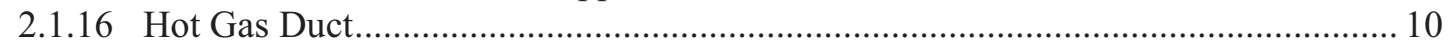

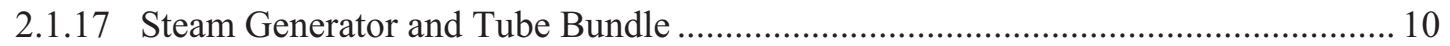

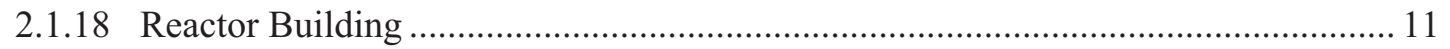

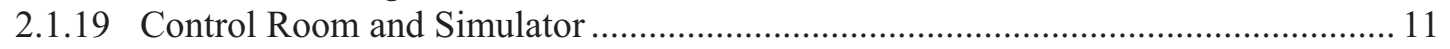

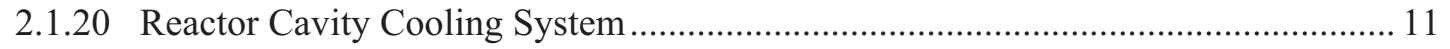

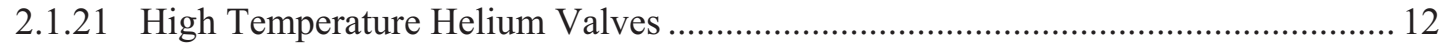

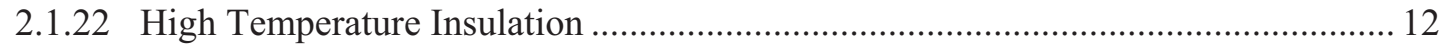

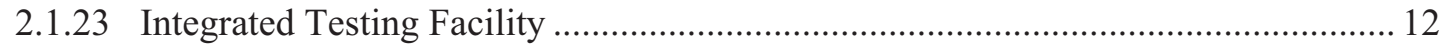

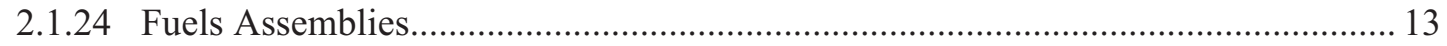

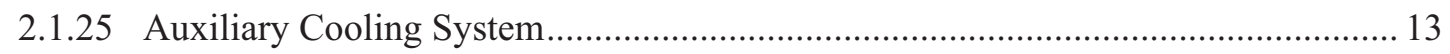

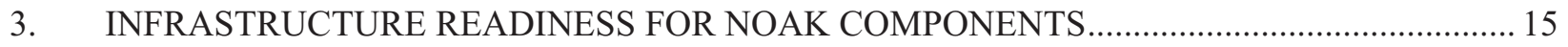

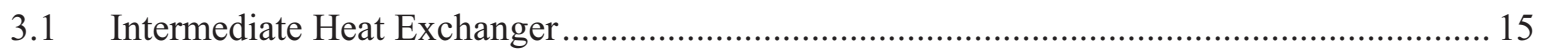

3.2 High Temperature Helium Valves .................................................................................. 15

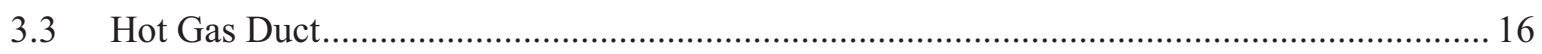

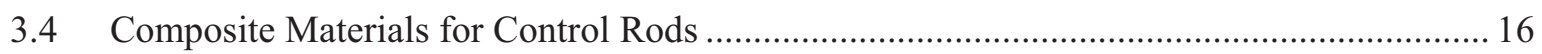

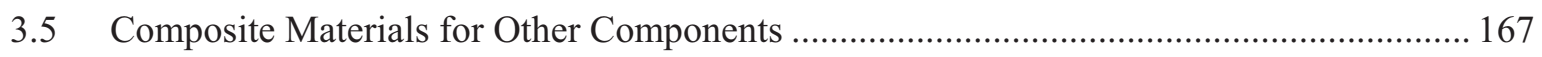

4. ADDITIONAL ASSESSMENT CRITIERIA FOR INFRASTRUCTURE READINESS .............. 18

4.1 Quality Assurance and Quality Control ...................................................................... 18

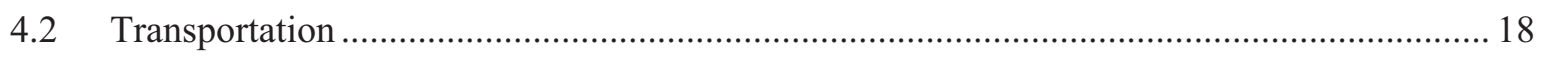

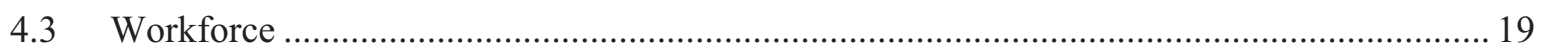




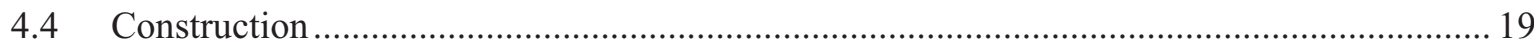

5. COMBINED INFRASTRUCTURE READINESS TABLE FOR AREVA AND

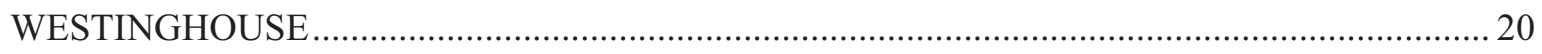

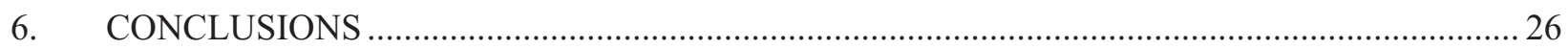

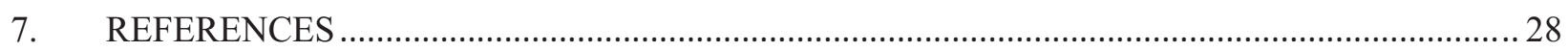

Attachment 1-Infrastructure Readiness Assessment for Next Generation Nuclear Plant, Westinghouse Electric Company LLC, Report Number NGNP-PRG-GEN-RPT-G-000301... ATT-1

Attachment 2-Infrastructure Readiness Assessment for the NGNP, AREVA, Document Number: 12-9142633-02 ATT-2 


\section{ACRONYMS}

AGR Advanced Gas Reactor

AP-1000 Advanced Passive -1000 MWt Reactor

ASME American Society of Mechanical Engineers

ASTM American Society of Testing and Materials

ATR Advanced Test Reactor

B\&W Babcock and Wilcox

DOE Department of Energy

FOAK first-of-a-kind

Gen III/III+ Generation III or III+

EPR Evolutionary Power Reactor

HPS helium purification system

HTGR high temperature gas-cooled reactor

ITF Integrated Testing Facility

NEAC Nuclear Energy Advisory Council

NGNP Next Generation Nuclear Plant

NOAK nth-of-a-kind

NRC Nuclear Regulatory Commission

QA/QC Quality Assurance and Quality Control

RCCS reactor cavity cooling system

RPV reactor pressure vessel

RSS reserve shutdown system

SAS Small absorber spheres

TRISO Tristructural-isotropic 


\section{NGNP Infrastructure Readiness Assessment: Consolidation Report}

\section{INTRODUCTION}

This report presents the results of an infrastructure readiness assessment performed by AREVA and Westinghouse for the Next Generation Nuclear Plant (NGNP) Project in support of the deployment of the first-of-a-kind (FOAK) high temperature gas-cooled reactor (HTGR). Areas assessed include industrial capabilities and capacities to produce components, meet quality assurance requirements, transport components, have a skilled workforce in place, and have the necessary fabrication and construction capabilities. The NGNP Project has a development and deployment timeframe of +2020 . The supplier's infrastructure readiness assessment reports met the Project's goals, which were to assess current infrastructure capabilities, identify development needs, and recommend improvements to support the deployment of the FOAK plant, with an understanding that the same infrastructure could be brought to bear on follow-on HTGRs.

The supplier's reports categorized various key infrastructure components into groups that described the level of infrastructure readiness that exists for each component. An overview of components and topics discussed in the infrastructure readiness assessment reports provided by AREVA and Westinghouse are provided in Sections 2 and 3 along with a brief NGNP Project evaluation of their input, with emphasis on those topics for which development programs are already in place. The FOAK plant components are discussed in Section 2 and the components specific to the Nth-of-a-kind (NOAK) plant are discussed in Section 3. Section 4 contains a comparison of assigned category ratings for each component.

Along with industry's ability to produce components, other essential factors vital in assessing industrial capabilities are: quality programs, ability to transport components, available skilled workforce, and adequate construction techniques. These important infrastructure capabilities are discussed in Section 5. The final conclusions are provided in Section 6. Westinghouse's and AREVA's infrastructure readiness assessment reports are included as attachments to this document. 


\section{INFRASTRUCTURE READINESS FOR FOAK PLANT COMPONENTS}

The NGNP Project will use this infrastructure readiness assessment to determine if the FOAK plant can be built within the +2020 timeframe and to ascertain what components can be sources of potential problems and schedule delays, in order to specifically address these issues. Independent suppliers, AREVA and Westinghouse, were contracted to perform this assessment because of their experience with commercial nuclear supply chains and the Evolutionary Power Reactor (EPR) and Advanced Passive 1000 MWt (AP-1000) reactor. The NGNP Project has several technical development programs for key components and the NGNP Project has provided additional input for these areas.

The supplier's reports categorized various key infrastructure components into groups that described the level of infrastructure readiness existed for each component or topical areas. The category rating of Readiness Level A, B, or C is assigned the following meaning:

- Readiness Level A means there are no significant issues that should prevent the component or topical area from being ready for deployment in the FOAK plant.

- Readiness Level B means the component or topical area could be ready for use in the FOAK plant if advanced planning is implemented soon. This added effort may be the result of long lead times or because some technical development is needed or qualification requirements need to be met.

- Readiness Level C means there are significant development and-or qualification needs that need to be addressed prior to deployment.

\subsection{Infrastructure Component Descriptions and Categorizations}

This section describes the infrastructure components assessed by AREVA and Westinghouse, gives the contractors component rating, and presents the NGNP Projects' concurrence or objection to the contractor's assessment. Statements provided below were taken from the Assessment Reports prepared and submitted by Westinghouse and AREVA to the NGNP Project.

\subsubsection{Control Rods}

Control rods are inserted into the outer reflector blocks to control and shape reactivity within the reactor core. Control rods are also inserted to shut down the reactor to cold conditions.

Westinghouse estimated a lead time of 3 years for producing metallic control rods and categorized the metallic control rods as Readiness Level A, which means there are no significant issues preventing them from being deployed in the FOAK plant.

AREVA stated that since control rods are replaceable components, the most conservative approach is to start using metallic control rods until the ceramic composite control rods are ready. AREVA categorized the metallic control rods as Readiness Level A.

The NGNP Project concurs with this component rating. Both Westinghouse and AREVA expressed interest in using ceramic composites in place of metallic control rods because composites would offer superior resistance to temperature and radiation induced degradation, but this technology is not ready for deployment in the FOAK plant. The use of composite materials in the NOAK plant is discussed in Section 3.4. 


\subsubsection{Cross Vessel}

The cross vessel is a large-diameter pressure vessel that has a substantial wall thickness, which connects the reactor pressure vessel (RPV) and the steam generator. The cross vessel is located external and concentric to the hot gas duct. The reactor inlet coolant returns to the core in the annulus located between the outer side of the hot gas duct and the inner wall of the cross vessel. The cross vessel is made of the same material as the RPV (SA 508/533). It is expected that an international supplier, such as Japan Steel Works, will be needed to manufacture the large forgings for this component.

Westinghouse estimated a 7-year lead time for cross vessels because of limited manufacturing capacity in this industry. However, they indicated that, with an early order, there should be no significant problems with deploying this component in the FOAK plant. Westinghouse categorized the cross vessel as Readiness Level A.

AREVA has indicated that ordering the cross vessel early reduces some schedule risks, and categorizes the cross vessel is a Readiness Level A.

The NGNP Project concurs with this component ratings and agrees that it is essential to schedule orders early to prevent long delays, especially if new orders for RPVs or other large components for domestic and international light water reactors (LWRs) being planned for construction are placed ahead of orders for FOAK plant components. A discussion about large forgings is presented in Section 2.1.14.

\subsubsection{Reserve Shutdown System}

The reserve shutdown system (RSS) is used to shut the reactor down to cold conditions. Shutdown occurs by having several bins of Small Absorber Spheres (SAS), located above the core, inserted into graphite channels. The SAS are made of $10 \mathrm{~mm}$ graphite spheres that contain $10 \%$ by weight of natural $\mathrm{B}_{4} \mathrm{C}$. When reactor operators are finished with the SAS they are extracted from the graphite channels and pneumatically transported back to the holding bins above the reactor core.

Westinghouse estimated a 3 year lead time to construct the RSS, stating that there is some basic design work needed. Westinghouse has categorized the RSS as a Readiness Level A.

AREVA did not address this system in their infrastructure readiness assessment report.

The NGNP Project concurs with this component rating, but recognizes that additional design work is needed to mature this system's design.

\subsubsection{Rankine Cycle Power Conversion System}

The FOAK plant will use a Rankine Cycle power conversion system, which involves taking subcooled feed water and driving it through a steam generator to produce superheated steam. The superheated steam passes through a steam turbine that converts mechanical work into electricity. There are several suppliers that have the capability to deliver high efficiency steam turbines and related equipment.

Westinghouse estimated it would take less than 3 years to have a suitable vendor manufacture the necessary components. Based on the similarities between the NGNP power conversion system and the power conversion systems used in fossil plants, Westinghouse categorized the Rankine cycle power conversion system as Readiness Level A.

AREVA indicated that there is sufficient industrial and nuclear experience and suitable vendors who can provide the needed equipment for a Rankine cycle power conversion system. AREVA therefore categorized the Rankine cycle power conversion system is a Readiness Level A. 
The NGNP Project concurs with this component rating for the Rankine Cycle power conversion system.

\subsubsection{Core Ceramic Structures - Graphite Blocks}

The reactor core contains fuel and graphite reflector blocks that have channels, guide sockets, and dowels. The graphite reflector blocks have channels cut through the graphite blocks to allow control rods to be inserted deep into the core. The graphite reflector blocks will be stacked on top of each other and will need to be precisely machined to allow for close tolerance fitting. All graphite internal structures need very precise machining.

Westinghouse stated that the estimated lead time to produce the needed graphite is 5 years and that industry's capability to produce the required amount of graphite for fuel and graphite reflectors for the FOAK plant is at a Readiness Level A.

AREVA stated that most graphite vendors do not have NRC approved NQA-1 programs in place, but determined graphite production to be sufficiently developed to be categorized as a Readiness Level A.

Based on its NGNP Graphite Development and Qualification Program experience, the NGNP Project considers the infrastructure readiness level for graphite production for the FOAK plant to be a Readiness Level C.

The NGNP Project identified incongruities with the expectations stated by Westinghouse and AREVA for the NGNP Project's expected scope of work, which was stated in their infrastructure readiness assessment reports. Both Westinghouse and AREVA have stated the expectation that the NGNP graphite program will develop graphite ASTM International standards and establish ASME graphite core component design rules necessary for design of HTGRs. Moreover, they expect the NGNP Project to qualify graphite vendors to supply ASME graphite that has the ASME/NRC pedigree necessary for use in constructing the NGNP.

The NGNP Graphite Development and Qualification Program is not authorized to and has no plans to setup and certify a graphite vendor's NQA-1 Quality Program, nor to obtain an ASME G-certificate to produce ASME nuclear grade graphite for the vendor [4]. Additionally, per ASME code, the plant owner is responsible for obtaining the necessary required ASME graphite design data, based on guidance from ASTM D-7219. The ASTM International standard, along with consultation from the NRC, will guide the plant owner as to the extent of statistical sampling needed for design and licensing acceptance for the FOAK plant. It is clear at this point in the design process that graphite qualification should be addressed in the very near future instead of waiting for a plant owner, but plans are needed that require these tasks and objectives to be identified and met.

The NGNP Graphite Development and Qualification Program is involved in developing the ASME graphite core component rules [4]. The NGNP Graphite Development and Qualification Program will undertake the role of facilitator to support NRC's review of the ASME code and the necessary data evaluation, benchmarking, and code modifications. The NRC review schedule for the ASME graphite core component design rules has not been included in the reactor supplier's infrastructure review. The NGNP Graphite Development and Qualification Program is performing experiments in the Advanced Test Reactor (ATR) right now that are designed to provide initial creep rates for moderate radiation doses and high temperatures of the leading graphite types.

Several aspects of graphite production are not often discussed, but are extremely important and have substantial impact on the NGNP Project. Graphite machining capability must also be considered in assessing the industrial infrastructure. Graphite vendors have not funded development of ASME qualified machining facilities that have the capabilities and throughput necessary to support FOAK during 
operational lifetime. ASME graphite machining facilities are required to have clean room conditions approaching the semiconductor industry requirements. An estimate for an ASME qualified graphite machining facility is based on prior experience in Germany is three years to build, train, and qualify operations at a cost of $\$ 13.7$ million with a $50 \%$ spread on cost.

\subsubsection{Circulator}

The helium circulator for the FOAK plant is designed to circulate the high temperature helium in the primary circuit. The helium circulator has two possible design considerations. The first design consideration is the submerged circulator, meaning the helium circulator is submerged in the primary coolant and that the system will contain electromagnetic bearings, electrical insulations, and many electrical penetrations. The biggest design concerns for this style of circulator are arcing, testing the catcher bearings, and getting the necessary nuclear qualification for subcomponents. The second design consideration is for the external circulator, which could be operated outside of the primary pressure boundary with a drive shaft penetrating the primary circuit to drive the impeller. There will be a need to use dry gas seal and a purge gas system to prevent contaminants from the primary circuit from escaping from the primary pressure boundary. The dry gas seals will need to be tested to ensure that the primary coolant does not escape

Westinghouse estimated that the lead time for a helium circulator for the FOAK plant would be 7 to 9 years, stating in their infrastructure readiness assessment report that additional design work is needed to select an internal or externally mounted circulator. Westinghouse categorized the circulator's impeller is an Readiness Level A, providing the temperature of the primary coolant at the circulator's location is less than $350^{\circ} \mathrm{C}$. If the temperature of the primary coolant were greater than $450^{\circ} \mathrm{C}$, the category would be a Readiness Level B. The current FOAK plant design has a reactor outlet temperature of $750^{\circ} \mathrm{C}$; the reactor inlet temperature is expected to be less than $350^{\circ} \mathrm{C}$.

AREVA categorized the readiness level of the motor design, active magnetic bearings, electrical insulation, electrical penetrations, and dry gas seals as a Readiness Level A. AREVA further stated that circulators in the $4 \mathrm{MW}-6 \mathrm{MW}$ range were within the current capabilities. AREVA categorized the overall helium circulator, including the impeller, at a Readiness Level A.

The NGNP Project concurs with a Readiness Level A component rating.

\subsubsection{Helium Purification System}

The helium purification system for the FOAK plant will be designed to control nonradioactive impurities as well as small amounts of radioactive impurities. Small amounts of the primary gas, approximately $1 \%$ of the total flow, will be continuously siphoned off at several locations in the primary circuit and purified. The purified helium will either be returned to the primary circuit or sent to a helium storage tank. The helium gas itself is readily available and can be supplied at very high purity.

Westinghouse estimated that the lead time for designing and building the HPS is 1 year. Westinghouse believes that the purification systems are commercially available and doesn't foresee any scheduling complications. Westinghouse therefore categorizes the helium purification system at a Readiness Level A.

AREVA stated that the helium purification system vendors do not have an NRC approved quality program and it could be a problem getting vendors to adhere to this program because of the small size of the project and the costs associated with setting up an NRC approved quality program. AREVA believes that early planning, design, and procurement is necessary to avoid negative schedule impacts. AREVA therefore categorizes the helium purification system at a Readiness Level B. 
The NGNP Project concurs with the Readiness Level A assessment because the required equipment and techniques that will be used in a helium purification system are commercially available and the nuclear industry has operational experience with purification systems.

\subsubsection{Instrumentation and Controls}

Instrumentation and controls (I\&C) in the FOAK plant will be used to measure environmental conditions in various locations. Environmental conditions of interest for these locations could include neutron flux, temperature, helium flow rate, pressure, moisture levels, and many others.

Westinghouse identified several instrumentation and sensor types that need to be developed for use in the FOAK plant. I\&C needed for specific NGNP equipment includes: high temperature sensors, helium sensors, pressure sensors, flow sensors, Instrumentation Controls and Human Machine Interface system, Post Accident Measurement Systems, RPV measurement instrumentation, neutron flux, instrumentation to determine temperature distribution in the core, instrumentation to determine stresses and temperatures of the core barrel, burnup measurements, and in service inspection equipment. The estimated lead time for these I\&Cs is estimated to be 4 to 6 years. Based on Westinghouse's assessment of the additional instrumentation needed for the FOAK plant, Westinghouse has categorized I\&C at a Readiness Level B.

AREVA believes the current FOAK plant will not require significant exotic instrumentation and that the current infrastructure should be adequate to meet the anticipated instrumentation needs. AREVA therefore categorized FOAK plant I\&C at a Readiness Level A.

The NGNP Project notes that currently existing instruments should be available for use in lower temperature areas of the plant; however, the following instruments will likely need to be developed: instruments to measure high gas and process fluid temperatures, instruments and techniques to measure three dimensional core power distribution, instruments to evaluate ever-changing core bypass coolant flow rates, instruments and techniques to identify conditions that will consume fatigue life and identify real-time online fatigue life usage and the remaining useful lifetime of components, control schemes to minimize thermal stresses and fatigue life usage of components, automated control systems that allow multiple units to be operated from a single work station, and resilient control systems to ensure the highest reliability. Instrumentation and control systems will be demonstrated and assessed during the initial startup test program and first FOAK plant cycle, as well as throughout the plant's life time.

While Type $\mathrm{N}$ thermocouples might be sufficient for $750^{\circ} \mathrm{C}$ gas temperatures, relatively drift-free and highly accurate temperature instruments will be required to measure gas and process fluids. Additional development will likely be needed to support gas temperatures above $750^{\circ} \mathrm{C}$. Possible instruments include high temperature fiber optics.

The graphite core with its gaps, long holes for coolant and control rods, and long neutron migration length is anticipated to present significant challenges to inferring local nuclear power distributions and produce a 3-D core power distribution. Water cooled reactors can use neutron detectors located in the core to sense local power. The high temperatures in gas cooled reactors might preclude locating detectors in the core. In gas reactors, neutrons from all parts of the core could significantly contribute to the signal at a local detector. The location and design of instruments will require considerable study. Instruments other than neutron detectors might be required, for instance gamma thermocouples might provide better data than neutron detectors. The development of instrumentation and associated core power distribution calculation techniques will be required before the FOAK plant is started up.

The NGNP project concurs with the Readiness Level B. 


\subsubsection{Digital Control Systems}

The nuclear industry is currently using analog control systems because they have been verified to be sufficiently reliable and accurate by the NRC. An effort is underway to upgrade NRC regulations to get digital control systems qualified for use in nuclear power plants. This will involve obtaining NQA-1 qualified data to determine how often digital controls fail and ensuring the accuracy of their readings in numerous scenarios.

Westinghouse indicated that significant work is needed to enable the use of digital control systems in a FOAK plant and to qualify the digital equipment to meet NRC requirements. It is expected that Gen III/III+ LWR plants will accomplish a majority of this task before the FOAK plant is deployed. Westinghouse therefore categorizes digital control systems at a Readiness Level B.

AREVA also expects the Gen III/III+ LWR plants to provide the necessary qualifications to receive NRC approval for digital control systems. AREVA therefore categorizes digital control systems at a Readiness Level B.

The NGNP Project concurs with a Readiness Level B component rating.

\subsubsection{Composite Materials - Core Structures}

Composite materials are currently available in industry, but there currently is no applicable ASME Code or NRC precedent for qualifying composite material for use in the nuclear industry, and there is no program pushing for its development. Composite material has several possible applications in HTGRs, such as: control rod guide tubes, the upper core restraint, and upper plenum shroud. Some of the more popular composite material options are $\mathrm{C}-\mathrm{C}$ and $\mathrm{SiC}-\mathrm{SiC}$. These composite materials have been determined to be specially adept for use in very high temperature and high radiation environments.

Westinghouse stated that they believe composite materials are sufficiently technically developed and adequate infrastructure exists to produce these materials for use in the FOAK plant, but there are qualification concerns that will limit the use of these materials in the nuclear industry. Westinghouse is interested in using composite materials for upper core restraints, lateral restraints, and tie rods, but it is unlikely that composite materials will be used in the FOAK plant in place of the current metallic designs for these components. Despite these qualification concerns, Westinghouse categorized composite materials in core structures at a Readiness Level A.

AREVA stated that composite components could be used in a FOAK plant, assuming advanced planning is used to facilitate their development and the qualification requirements. AREVA has also stated that an infrastructure exists to adequately produce composite materials, but the qualification strategy has not been developed. AREVA therefore categorized composite material for use in the FOAK plant at a Readiness Level B. However, they noted that the qualification of these materials does pose a challenge.

The NGNP Project concurs with a Readiness Level B component rating. There is currently no R\&D plan to actively address the regulator issues regarding the use of composite materials.

\subsubsection{Metallic Materials and Internal Metallics}

The metallic materials and internal metallics are high temperature materials that are specially suited to be used inside of a HTGR. Metallic materials and internal metallics include the upper core restraint and upper plenum shroud. High temperature metals usually contain high levels of nickel because nickel helps maintain the alloys strength at elevated temperatures. Also, these materials often contain significant amounts of chromium, which is used to resist corrosion at high temperatures. In a HTGR environment, 
the chromium material oxidizes and forms a protective oxide layer that prevents environmental impurities from interacting with the base metal surface, thereby reducing the amount of corrosion.

Westinghouse believes that the necessary materials and qualifications will be ready for use in the FOAK plant and that there will be sufficient infrastructure to produce the required materials as needed. The two materials that were specifically mentioned in Westinghouse's report are Alloy $800 \mathrm{H}$ and Alloy 617. Hastelloy X and XR were also mentioned, but there was no rating attached to these materials. Westinghouse stated in their report that Hastelloy X and XR are needed and they recognize that there is no ASME committee addressing these materials for use in the FOAK plant. Westinghouse therefore categorized the NGNP metallic materials at a Readiness Level A.

AREVA stated that there is substantial industrial experience in producing components of Alloy $800 \mathrm{H}$, $316 \mathrm{H}, 2.25 \mathrm{Cr}-1 \mathrm{Mo}$, Grade 91, and Hastelloy X and XR; however, there is limited use in the nuclear industry. The overall infrastructure for these materials is adequate, but material qualification programs are needed. Because of the lengthy issues involved in receiving nuclear qualifications, AREVA categorized metallic materials and internal metallics at a Readiness Level B. Advance planning will be needed to deploy these materials in the FOAK plant.

The NGNP Project concurs with Readiness Level B component rating, which is also based on the status of material codification in ASME. The NGNP Project set up the High Temperature Materials Program, which specifically addressed the materials qualification issues for Alloy $800 \mathrm{H}$ and performed the necessary R\&D work [3]. Based on that work, Alloy $800 \mathrm{H}$ is expected to be the main metallic material for a FOAK plant, because it has the highest operating temperature. The Materials Program is also addressing issues with using Alloy 617 in the NOAK plants. No other qualification work is being done for high temperature metals by the NGNP Project; specifically, Hastelloy X and XR are not being addressed by a formal program.

The NGNP Project is very involved with ASME in getting materials qualified for use in the FOAK plant. In December 2010, ASME approved the proposed Section III, Division 5 for the ASME Boiler and Pressure Vessel (BPV) Code. Section III, Division 5 will now proceed to publication, scheduled to be issued next July 2011 as part of the 2011 ASME BPV Code Addenda. Division 5 provides construction rules for high temperature reactors, including both high temperature gas-cooled reactors and liquid metal reactors. Division 5 also includes the graphite rules approved earlier by ASME. Future revisions of Division 5, mainly based on the results from the various ASME/Department of Energy (DOE) Generation IV Reactor Materials Project tasks, still need to be incorporated, but this initial issuance represents a major step forward for the Next Generation Nuclear Plant (NGNP). Division 5 Code Cases or direct revisions to the Code can now be issued as needed, addressing such topics as extending the current temperature and operating time limits of Alloy $800 \mathrm{H}$ or publishing the elevated temperature material data for Alloy 617.

\subsubsection{High Temperature Concrete}

High temperature concrete maintains its strength and has a significant resistance to cracking at high temperatures. This concrete will be used in the construction of the reactor building and the reactor cavity. The high temperature concrete will need to be produced in large quantities by local suppliers to required specifications.

Westinghouse sees no significant issues with using local concrete suppliers, so categorizes high temperature concrete at a Readiness Level A.

The necessary quantities of concrete produced by local suppliers is believed, by AREVA, to add schedule risks. AREVA has categorized high temperature concrete production at a Readiness Level B. It 
is expected by AREVA that the required quantities of concrete could be obtained with advanced planning, but the possibility exists that there may be a need to expand the local infrastructure.

The NGNP Project concurs with the Readiness Level A component rating.

\subsubsection{Fuel Handling - Pebble Bed Design}

The fuel handling system addressed in this section is for the pebble bed reactor. It consists of a fuel handling device that removes pebbles from the bottom of the pebble bed reactor core and uses a gammaspectrometer to determine the burn-up level of each pebble. The pebble is either discarded as spent fuel or reintroduced at the top of the core.

Westinghouse foresees that the qualification will require substantial lead time, which is estimated to be 3 to 4 years. Westinghouse has stated in their report that there should be no significant problems preventing delivery of this system and assigned a Readiness Level A.

AREVA didn't provide any input for this system.

The NGNP Project concurs with Westinghouse's component rating.

\subsubsection{RPV and Large Forgings}

The RPV for the FOAK plant will have thick walls and be very large in both height and diameter. The RPV for the FOAK plant will be made of SA 508/533, which is the same material used for RPVs for LWRs. The RPV for the FOAK plant is substantially larger than the RPV for LWRs. The large forgings, like the RPVs, can be produced by heavy industries, such as Japan Steel Works. There is sufficient worldwide capability to produce very large forgings, but the availability of this capacity will depend on the potential backlog, which may be caused by a large number of heavy forgings orders placed by new LWR projects.

Westinghouse estimates a current lead time of 10 years for a FOAK plant RPV. This estimate considers a 5 to 6 year advanced reservation period and an additional 3 to 4 year production period. Even though the current infrastructure needed to produce very large pressure vessels does exist, based on the long lead times, Westinghouse categorized RPV and large forgings at a Readiness Level B.

Based on the long lead time and the limited capacity of the large forgings industry, AREVA categorized RPV and large forgings at a Readiness Level B. AREVA stated that ordering large forgings early, within the next few years, greatly reduces the schedule risks.

The NGNP Project concurs with the Readiness Level B component rating, and believes that advancing the design enough to allow for advanced ordering is crucial to reducing schedule risks. There are several potential large forging vendors that were not identified in Westinghouse's and AREVA's reports, such as those listed in references 1 through 3. The NGNP project believes that development of specifications and placing orders early is still necessary to ensure a timely delivery.

\subsubsection{Core Barrel with Internal Support Structures}

The core barrel is a tall thin cylinder that encompasses the perimeter of the reactor core. It is open on the top and attached to a massive metallic core support structure at the bottom.

Westinghouse indicated in their report that fabrication development would be needed. Additionally, Westinghouse stated that there were no nuclear qualified vendors that are currently fabricating structures similar to the core barrel. It has been concluded by Westinghouse that vendors will need to be developed 
and there is an estimated lead time of 5 years. Westinghouse has categorized the core barrel at a Readiness Level B.

AREVA stated that advanced planning was needed for the deployment of the core barrel in the FOAK plant, and therefore categorized the core barrel with internal support structures at a Readiness Level B.

The NGNP Project concurs with the Readiness Level B component rating.

\subsubsection{Hot Gas Duct}

The hot gas duct is a multilayered insulated assembly that transports high temperature helium coolant from the reactor to the steam generator or possibly an intermediate heat exchanger (IHX). The hot duct and the cross vessel form concentric cylinders and the hot duct is located inside of the cross vessel.

Westinghouse stated that there currently is not a supplier to produce the hot gas duct and that an estimated 5 years lead time is required to deploy this technology. Westinghouse therefore categorized the hot gas duct component at a Readiness Level C.

AREVA stated that the hot gas duct may require material technology development if the reactor outlet temperature exceeds $750^{\circ} \mathrm{C}$, but at reactor outlet temperatures of $750^{\circ} \mathrm{C}$ or lower, the technology is confirmed to allow its use of a metallic liner such as Alloy $800 \mathrm{H}$. AREVA indicated that the hot duct and duct liner are well within the capabilities of the current industry and therefore categorized the hot gas duct component at a Readiness Level A.

The reason for the discrepancy between AREVA and Westinghouse on the capability to produce and deploy the hot gas duct could be, in part, Westinghouse's lack of experience with hot gas duct technology. Previous Westinghouse HTGR reference designs did not include a hot gas duct. The hot gas duct is considered to be the limiting high temperature duct and insulation application for the FOAK NGNP design, but it has been determined that design issues are currently being successfully solved. Some of the technical challenges that face the hot gas duct are hot to cold leg leak detection, high temperature materials qualification, and mechanical systems problems associated with the use of bellows and the cross vessel.

It is expected that inspections can be done during outages and there is growing confidence that thermal imaging can be used to detect hot leaks into the cold channel that surrounds the hot gas duct. It is expected that the outer material layer for the cross vessel will be made of SA 508/533, whereas the inner material that will be in contact with the high temperature helium could be Alloy $800 \mathrm{H}$. The insulation that will likely be used between the reactor outlet and the inlet is a conventional high temperature insulation. The mechanical systems that will be required to accommodate large temperature changes and significant thermally induced tensile loads are within the expected material limits, as well.

The NGNP Project concurs with Readiness Level A component rating.

\subsubsection{Steam Generator and Tube Bundle}

The steam generator for the FOAK plant is designed to produce superheated steam by pumping water vertically through tube bundles, while high temperature helium flows over the tube bundles. The current design for this steam generator is a once through helical coil steam generator that contains an economizer, evaporator, and primary superheater section made of $2.25 \mathrm{Cr}-1 \mathrm{Mo}$ and a finishing superheater section made of Alloy $800 \mathrm{H}$ [8]. The primary superheater and the finishing superheater tube sections will be joined by a bimetallic weld.

Westinghouse stated that there are numerous design and fabrication challenges associated with producing the steam generator tube bundles. Westinghouse estimates that a 5 year lead time is needed to 
produce the FOAK plant steam generator. Based on the technical development needed to fabricate the steam generator, Westinghouse categorized steam generator and tube bundle components at a Readiness Level B.

AREVA stated that modern fabrication techniques need to be developed to produce the helical coil design. It also has concerns about the willingness of companies to adopt the necessary qualification programs to produce nuclear components because of the significant cost required to establish quality programs. AREVA categorized steam generator and tube bundle components at a Readiness Level B.

Some HTGR steam generator designs, such as the HTR-Module plant, use $800 \mathrm{H}$ fully along the length of the tubes, thus avoiding the bimetallic weld.

The NGNP Project concurs with the Readiness Level B component rating.

\subsubsection{Reactor Building}

The reactor building design is strongly dependent on the design of the reactor module and the geographical location. The reactor building will either be a fully or partially embedded structure, which will be based on construction cost, operability, plant maintenance, external hazards, and location. The reactor building will be fortified and capable of surviving an airplane crash.

Westinghouse did not offer input for the reactor building.

AREVA stated that additional design information is needed before final design specifications can be made. Based on their assessment, they categorized the FOAK reactor building component at a Readiness Level A.

The NGNP Project concurs with the Readiness Level A component rating.

\subsubsection{Control Room and Simulator}

The control room is the central location for information dissemination to operators and reactor controls for the plant. The simulator is an independent demonstration and training capability designed to exactly simulate the control room, providing a test bed for the software.

Westinghouse stated that these FOAK plant components are required to obtain NRC approval. Westinghouse has indicated that the lead time on these components is 5 to 9 years. Westinghouse therefore categorized control room and simulator component production at a Readiness Level B.

AREVA didn't comment on the control room or the simulator.

The NGNP Project concurs with the Readiness Level B component rating.

\subsubsection{Reactor Cavity Cooling System}

The reactor cavity cooling system (RCCS) is unique to the HTGR. Its primary functions are to protect the reactor cavity concrete and RPV supports during normal operations and to prevent long-term degradation of the concrete. The RCCS also provides an additional means of heat removal for the reactor when neither the main heat transport system nor the shutdown cooling system is available.

Westinghouse indicated that the RCCS is available with advanced planning and therefore categorized it at a Readiness Level B.

AREVA designers are considering RCCS concepts and planning to use very conventional components and structures. AREVA categorized RCCS components at a Readiness Level B. 
The NGNP Project concurs with the Readiness Level B component rating, but believes the RCCS requires additional work to qualify accident scenarios, which is being addressed by Argonne National Laboratory.

\subsubsection{High Temperature Helium Valves}

Westinghouse and AREVA discussed different types of valves in their reports. Westinghouse discussed numerous flow control valves for the FOAK plant, whereas AREVA discussed only the isolation valves for the NOAK plant.

Westinghouse identified several types of valves expected to be used in the FOAK plant including: hand valves, check valves, control valves, instrument root valves, and safety relief valves. Westinghouse has indicated that some additional planning is needed before current valves are ready for deployment in the FOAK plant. Some problems foreseen with current valves are leak tightness and development for temperatures above $610^{\circ} \mathrm{C}$. Westinghouse therefore categorized helium valves for the FOAK plant at a Readiness Level B.

AREVA didn't provide any input for FOAK plant helium values. AREVA did provide input for NOAK plant helium valves, which are discussed in Section 3.2.

The NGNP Project concurs with the Readiness Level B component rating.

\subsubsection{High Temperature Insulation}

Insulation used in high temperature environments has been shown to have bonding problems over extended periods of time at elevated temperatures. It is expected that the insulation will not stay bonded to its intended surface for the life of the components. Additional research and development is therefore needed.

Westinghouse recommends performing high temperature insulation testing of various ceramic fibers, specifically, $\mathrm{Al}_{2} \mathrm{O}_{3}$ and $\mathrm{SiO}_{2}$. The most significant problem with the insulation is achieving long term adhesion to the bonding surfaces, such as the hot gas duct. It is expected that the capability to bond these materials to surfaces is obtainable with advance planning. Westinghouse expects that a successful development of an integrated design would take approximately 3 years. It therefore categorizes the high temperature insulation component at a Readiness Level B.

AREVA did not address the high temperature insulation component.

The NGNP Project concurs with the Readiness Level B component rating.

\subsubsection{Integrated Testing Facility}

The use of a large-scale, integrated high temperature testing facility for the purposes of demonstrating the development and performance of heat transport system related components such as heat exchangers, circulators, and valves was proposed during the preconceptual design phase. The concept for such a facility as a new element of INL and DOE infrastructure was developed during subsequent studies as the component test capability. Use of such a facility was factored into many of the Technology Development Roadmaps and associated test plans for those components for which development was considered to be on the critical path for deployment of the FOAK plant. Pursuit of the component test capability was ultimately canceled by DOE in FY 2010 in favor of pursuing alternate paths-forward for component development, including testing by the component vendors. 
An Integrated Testing Facility (ITF) for FOAK plant components was identified by Westinghouse as an important infrastructure element. Westinghouse stated that the ITF was necessary to reduce FOAK uncertainties. It has been estimated that it would take 4 years to design, build, and commission the facility and 3 years to complete component testing. The facility was determined to be obtainable with advanced planning, so Westinghouse categorized the capability to produce the ITF component at a Readiness Level B.

AREVA did not address the ITF.

The NGNP Project concurs with Westinghouse's rating of B. The Project, however, is continuing to move towards identification of alternate paths-forward as discussed above.

\subsubsection{Fuels Assemblies}

The TRISO fuel is made up of several different protective layers. The fuel kernel will be either UCO or $\mathrm{UO}_{2}$. The fuel kernel is coated by a porous carbon buffer encased in an inner pyrolytic carbon. A layer of silicon carbide covers the inner carbon layer. The outer layer of a TRISO particle consists of outer pyrolytic carbon. These TRISO particles, pressed with graphite into compacts or pebbles, undergo additional processing that results in a final fuel product, either a compact or a fuel pebble.

Westinghouse estimated a 5 year lead time for sustained pebble bed fuel production for the FOAK plant. It also identified that the AGR Fuel Development and Qualification Program needs to complete their fuel qualification program and develop a manufacturing capability that can sustain the FOAK plant and possibly follow-on HTGRs. Westinghouse categorized the current infrastructure readiness level of fuel production at a Readiness Level C.

AREVA did not discuss prismatic fuel because it was being adequately addressed by the AGR Fuel Development and Qualification Program.

The NGNP Project concurs with the Readiness Level C component rating. The latest acquisition strategy for the AGR Fuel Development and Qualification Program is to start addressing pebble bed fuel. The NGNP Project is currently performing the second of five experiments to verify and qualify the fuel [6]. The current experiment is to demonstrate large scale fuel performance, which is expected to remain in the ATR at INL until March-April 2013, timeframe. There is an upcoming B\&W demonstration that will show the throughput for one fuel producing line. Based on that, an actual production requirement will be made to determine the size of the manufacturing process that will be needed to produce fuel for the FOAK plant. The initial demonstration of a single production line is planned for March 2011 and a final demonstration is planned for September 2011 [6].

\subsubsection{Auxiliary Cooling System}

The auxiliary heat exchanger for the FOAK plant is expected to be much smaller than the steam generator because it will have a smaller heat duty and should not need to have nearly the thermal effectiveness as the steam generator. It is expected that high temperature materials may be needed for this system because of the wide variety to inlet gas temperatures and conditions that the system may experience.

Westinghouse did not address the auxiliary cooling system.

A possible design strategy that AREVA may incorporate in developing this heat exchanger is to minimize manufacturing challenges rather than designing the heat exchanger to maximize thermal efficiency. The other auxiliary cooling system component that AREVA formally addressed in their infrastructure report was the auxiliary cooling system circulator. The required capacity for the auxiliary 
cooling system circulator is expected to be much smaller than that of the main helium circulator in the primary circuit. The circulator will be designed to operate in a wide variety of conditions, including fully pressurized and fully depressurized; the motor will need to be designed to accommodate these and other operational challenges. Based on recent advances in synchronous motors and solid-state power electronics, industry is expected to be able to produce the auxiliary cooling system circulator for the FOAK plant.

AREVA's auxiliary cooling system is also known as the core conditioning system and the shutdown cooling system in other designs. AREVA offered specific information about two major components in the auxiliary cooling system. AREVA has assessed the readiness of the auxiliary cooling system heat exchanger and circulator. The details of these systems will be dependent on the design selected. AREVA stated that some general characteristics are clear, which allows them to make an assessment of the infrastructure readiness to produce this system.

AREVA has indicated that additional design work is needed to select a specific design. Based on the current state of development, AREVA categorized the readiness level of the RSS at a Readiness Level A.

The NGNP Project concurs with the Readiness Level A component rating. 


\section{INFRASTRUCTURE READINESS FOR NOAK COMPONENTS}

The design and configuration uncertainties associated with NOAK plants make it difficult to speculate about components and materials, but some basic assumptions can still be made about NOAK plants. It is expected that the reactor outlet temperature will be higher, which would likely require the use of different materials, different components, and possibly different configurations. Five components from Westinghouse's and AREVA's Reports were evaluated for use in NOAK plants. Both suppliers provided an infrastructure readiness assessment, which has been summarized below in subsequent subsections. The NGNP Project also provided input with an assessment of the infrastructure capabilities to produce and deploy these components.

\subsection{Intermediate Heat Exchanger}

The intermediate heat exchanger (IHX) is expected to operate in a high temperature (up to $950^{\circ} \mathrm{C}$ ) environment for the NOAK plant, but there are so many unknowns that it is difficult to specify IHX properties. Possible options for IHX types include shell and tube and various compact designs. Potential secondary heat transport loop fluids, which may impact the design of the IHX, are helium, water/steam, nanofluids, and molten salts. The NGNP Project is doing preliminary IHX work and the High Temperature Materials Program is working on developing codification data for Alloy $800 \mathrm{H}$ and Alloy 617. Other possible IHX materials are being considered by suppliers, including Alloy 230, Hastelloy X, ceramic material, and foam materials, but these are not currently being addressed by the NGNP Project.

Westinghouse stated that there are difficulties expected with fabrication, joining, corrosion, and life expectancy for NOAK plant IHXs. Westinghouse categorized the ability to produce the IHX component for the NOAK plant at a Readiness Level C. Westinghouse also stated that the materials that could be used in the IHX for the NOAK plant needs significant development before the materials can be deployed.

AREVA assessed the IHX as requiring substantial development to determine the type, working fluids and their characteristics, plant operating temperature, and expected plant power levels. An adequate infrastructure does not exist to support the deployment of the IHX for the NOAK plant. AREVA therefore categorized the IHX component at a Readiness Level C.

The NGNP Project concurs with the Readiness Level C component rating. The necessary codification of materials and joining techniques in Section III of the ASME BPV Code are inadequate for deployment and as a result, fabrication techniques must be developed.

\subsection{High Temperature Helium Valves}

In Section 2.1.21, Westinghouse discussed the use of helium service valves for use in the FOAK plant, but did not provide any additional information about the helium service valves for use in NOAK plants. AREVA did not discuss the use of valves for the FOAK plant, but did provide information about isolation valves for use in the NOAK plants. In this section, a summary of AREVA's assessment has been provided, along with input from the NGNP project.

This section discusses the possible use of helium isolation valves with the intended purpose of deploying them in an NOAK plant. These valves are designed to isolate the primary or secondary heat transport circuits. AREVA has indicated that there could be a need for some specific heat transport configuration that may require high temperature helium valves to isolate the primary or secondary heat transport circuit for the NOAK plant. Work was done on the German HTGR process heat program in the 1980 s that encouraged these types of valves for process heat applications. The technology currently exists to fabricate these valves, but there are no known manufactures. AREVA stated that with advance planning, the development of very high temperature values should be achievable. 
AREVA categorized the infrastructure capabilities to produce high temperature helium isolation valves as having Readiness Level B.

The NGNP Project concurs with the Readiness Level B component rating.

\subsection{Hot Gas Duct}

In Section 2.1.16, the hot gas duct for the FOAK plant was discussed by both Westinghouse and AREVA. This section considers the hot gas duct for an NOAK plant at higher temperatures. The hot gas duct is a structural cylinder that provides a boundary between the reactor outlet gas and the reactor inlet gas and provides a structural support for insulation. The hot gas duct for the NOAK plant may have to endure higher reactor outlet temperatures and possibly be of greater size than the FOAK plant. The changes in the reactor outlet temperature are expected to result in material changes for the hot gas duct.

Westinghouse provided input on the FOAK plant and assessed the infrastructure capabilities as having a Readiness Level C. It is easily inferred that Westinghouse would maintain the Readiness Level of $\mathrm{C}$ for NOAK plants.

AREVA speculated, based on their preconceptual design work, that follow-on HTGRs would likely use ceramic composite liners for the hot duct's inner surface. AREVA stated in their infrastructure readiness assessment report that it is presumed that follow-on plants are far enough in the future that ceramic composite liners could be achievable with advance planning. AREVA therefore categorized the hot gas duct for NOAK plants at a Readiness Level B.

The hot gas duct is a complex mechanical system that will be subject to thermal expansion and possibly significant thermal gradients, which will develop complex loading scenarios for both the RPV and steam generator. In addition to complexities associated with thermally induced loadings on the supporting structures, there are significant material issues associated with operating the hot gas duct at reactor outlet temperatures upwards of $950^{\circ} \mathrm{C}$. The number of materials that can be used at these temperatures is very small. There has been interest in using Alloy 617 and/or composite materials. These materials will need to be qualified in the ASME code for use at these elevated temperatures. The NGNP Material Research and Development program is working to get Alloy 617 added to the code for use at elevated temperatures, but no program exists to get composite materials deployed in the code. Based on the complexities associated with operating at elevated temperatures, the NGNP Project categorizes the hot gas duct component for a NOAK plant to be at a Readiness Level C.

\subsection{Composite Materials for Control Rods}

Metallic control rods evaluated by Westinghouse and AREVA in Section 2.1.1 were determined adequate for use in the FOAK plant, but the outlet temperatures approaching $950^{\circ} \mathrm{C}$ expected in the NOAK plant would be extremely challenging for metallic control rods in the inner core region.

Westinghouse and AREVA expressed interest in using C-C or SiC-SiC composites in place of metallic control rods because composites offer superior resistance to temperature and radiation induced degradation, but this technology is not sufficiently matured for nuclear applications. There is nothing in the ASME Code that addresses the use of composite materials for nuclear applications, therefore, significant qualification work is required. Control rods for nuclear reactors need to be able to move throughout the length of the active core without hindrance. There is a risk that during thermal transients, metallic control rods can warp and have limited mobility through the guide channels.

The core control rods, needed to control and shutdown the reactor, are also exposed to very-high neutron fluence. It is expected that during a depressurized conduction cool down, the maximum temperature of the core should be just above the current short-term allowable temperature limits for high- 
temperature metals. During a pressurized conduction cooldown the temperatures are lower, but still sufficiently high that it excludes the use of most high temperature materials for control rods. C-C or SiC$\mathrm{SiC}$ composites have a much greater allowable temperature and neutron fluence.

The NGNP Project agrees with Westinghouse and AREVA that composite control rods have merit. The NGNP Project recognizes that the use of composite materials in the NOAK plants will require a development program specifically tailored to address material $R \& D$ and the qualification process for this material.

\subsection{Composite Materials for Other Components}

Composite materials have become very attractive considerations for use in high temperature environments. It is expected that NOAK plants will operate at higher reactor outlet temperatures, approaching $950^{\circ} \mathrm{C}$, and there are locations within the core that may require the use of composite materials, such as: control rod guide tubes, the upper core restraint, upper plenum shroud, and possibly the hot gas duct [9]. It is expected that operating reactors at these temperatures will reduce the lives of metallic structures or even eliminate them from consideration.

It is important to belabor the point that composite materials are currently possible options with advanced planning for use in the FOAK plant, but they could very well become requirements for use in NOAK plants, even thought they were not addressed by Westinghouse and AREVA for use in the NOAK plants. 


\section{ADDITIONAL ASSESSMENT CRITIERIA FOR INFRASTRUCTURE READINESS}

Four areas are just as vital to the success of the NGNP Project as industry's ability to manufacture components for the NGNP. These topical areas, which need to be clearly addressed to fully ascertain the capabilities of industry to properly construct a FOAK NGNP, include: quality assessments and quality control programs, transportation of components, available skilled workforce, and adequate construction capabilities and techniques. Inadequacies in any of these areas could result in project complications, delays, or even failure.

\subsection{Quality Assurance and Quality Control}

The NGNP is subject to ASME NQA-1 quality programs, making it necessary to ensure that programs are in place to reduce the chances of project schedule delays. The lead time to acquire an ASME N-Stamp and comply with ASME NQA-1 standards depends on the quality program that each component manufacturer has in place.

The Quality Assessment (QA)/Quality Control (QC) program for the NOAK plant was indicated by Westinghouse to have an 8-year lead time before all the necessary vendors obtain nuclear qualifications. This lead time estimate is dependent on the willingness and speed of the vendors. Westinghouse indicated the development of QA/QC programs for the NGNP is obtainable with advance planning and therefore categorized it at a Readiness Level B. The long lead time and the dependence on the vendor's willingness to get the required nuclear qualifications is the resulting justification for the assessment.

AREVA's assessments of QA/QC programs is dependent on industry's willingness to cooperate with the QA/QC programs. This assessment resulted in their categorization of QA/QC at a Readiness Level B.

The NGNP Project concurs with these Readiness Level B assessments.

\subsection{Transportation}

Land routes to the construction site are expected to necessitate shipping subassemblies instead of the intact forgings. If the subassemblies are shipped by truck there may be significant upgrades required to bridges and roads that could add to the lead time. Very large subassemblies cannot be shipped by rail because of height restrictions. If the construction site is assessable by barge, significantly fewer constraints would be placed on transporting components.

Some of the largest forgings are the RPV and the steam generator, which can be fabricated on site. This option will be more costly and require more time, but is completely within current capabilities. Westinghouse therefore categorizes transporting FOAK plant components at a Readiness Level A.

AREVA believes that delivering some components to the construction site and fabricating them there will increase costs and has the potential to delay the project schedule. AREVA further stated that transporting the larger NGNP components would be slightly more challenging, but does not expect it to be a strong discriminator. AREVA therefore categorized transporting large FOAK plant components as a Readiness Level B.

The NGNP Project concurs with the Readiness Level B rating because even though large components can be shipped in pieces and fabricated on site, advanced planning must be used to prepare for the fabrication of large components. Additionally, the construction site will need to be reached via roads and bridges, which may need to be modified to accommodate the weight and size of the transported parts of the forging assembly. 


\subsection{Workforce}

Westinghouse believes that a local skilled labor force (qualified boilermakers, pipefitters, electricians, and iron workers) will be in short supply, requiring traveling workers from other states and communities. If the NGNP is competing for skilled labor with eight or more LWR domestic units, it is expected that the labor shortage could be severe. Westinghouse therefore categorized the workforce component at a Readiness Level B.

According to AREVA, there are no workforce problems foreseen with developing any of the specified components. AREVA declared that there is no significant issue with the current workforce developing a FOAK NGNP. However, AREVA categorized the workforce component at a Readiness Level B.

The NGNP Project concurs with the Readiness Level B component rating.

\subsection{Construction}

Several qualified construction companies have the capacity and experience to build a full-scale HTGR. It is expected that the capabilities of construction companies will increase as more domestic LWRs are built.

Westinghouse indicated that the construction infrastructure is sufficient to produce the FOAK NGNP with no significant issues. It therefore categorized the construction of a FOAK plant at a Readiness Level A. It is expected that any existing infrastructure limitations will diminish as the LWR plants are constructed prior to the construction of the NGNP.

AREVA stated that the FOAK plant will be constructed slightly after the first wave of new LWRs, and they expect infrastructure limitations to be greatly reduced as the NOAK plant moves toward construction. AREVA therefore categorized Construction of a FOAK plant at a Readiness Level A.

The NGNP Project concurs with these Readiness Level A assessments. 


\section{COMBINED INFRASTRUCTURE READINESS TABLE FOR AREVA AND WESTINGHOUSE}

Westinghouse and AREVA assessed the current capabilities of industry to determine if there is sufficient infrastructure to deploy a FOAK HTGR. Both suppliers identified key components and topical areas for the FOAK plant and they assessed industry's ability to produce the components, meet quality assurance requirements, transport components, have skilled workforce in place, and have the necessary construction capabilities to build the plant. They performed the assessment by grouping the components into Readiness Levels A, B, and C as defined in Section 2.

AREVA's and Westinghouse's assessments of each component and topical area have been combined and placed in Table 1 for comparison purposes. The lead times provided in the table were estimated by Westinghouse. The notes in Table 1 are key excerpts from both AREVA's and Westinghouse's reports.

Table 1. Westinghouse's and AREVA's Infrastructure Category Ratings

\begin{tabular}{|c|c|c|c|c|}
\hline Component & $\begin{array}{c}\text { Westinghouse } \\
\text { Category* }\end{array}$ & $\begin{array}{c}\text { AREVA } \\
\text { Category** }\end{array}$ & Lead Times & Notes \\
\hline Control Rods & A & A & 3 years & $\begin{array}{l}* \text { Successful prototype developed and tested for } \\
\text { ROT } \leq 750^{\circ} \mathrm{C} \\
* \text { Metallic and ceramic control rods were given a } \\
\text { rating of A } \\
* * \text { Since control rods are replaceable } \\
\text { components, the path with least risk for near- } \\
\text { term deployment may involve initial use of } \\
\text { metallic rods with future substitution of } \\
\text { composite or hybrid metallic-composite rods for } \\
\text { improved performance margins }\end{array}$ \\
\hline Cross Vessel $^{\dagger}$ & A & A & $\begin{array}{l}7 \text { years, } \\
\text { dependent on } \\
\text { demand }\end{array}$ & Similar to pressure vessel, but smaller in size \\
\hline $\begin{array}{l}\text { Reserve } \\
\text { Shutdown } \\
\text { System (RSS) }\end{array}$ & A & $\begin{array}{l}\text { Not included in } \\
\text { infrastructure } \\
\text { readiness } \\
\text { assessment }\end{array}$ & 3 years & $\begin{array}{l}\text { *RSS basic design needs additional work, } \\
\text { functional performance confirmed by tests, } \\
\text { qualification tests to be performed }\end{array}$ \\
\hline $\begin{array}{l}\text { Rankine Cycle } \\
\text { Power } \\
\text { Conversion } \\
\text { System }^{\dagger}\end{array}$ & A & A & $<3$ years & $\begin{array}{l}\text { *Multiple suppliers have the capability to supply } \\
\text { needed equipment for steam Rankine cycles for } \\
\text { FOAK NGNP, which is similar to fossil plants } \\
\text { equipment } \\
\text { ** The Brayton cycle is specifically addressed } \\
\text { for the NOAK plant and is given a Readiness } \\
\text { Level B rating }\end{array}$ \\
\hline $\begin{array}{l}\text { Core Ceramic } \\
\text { Structures, } \\
\text { Graphite } \\
\text { Blocks }\end{array}$ & A & A & 5 years & $\begin{array}{l}\text { *ASME code developed has been started for } \\
\text { graphite, radiation tests needed } \\
* * \text { Most suppliers do not have NRC approved } \\
\text { QA programs, NRC does not have precedent for } \\
\text { acceptance of composite material, } \\
\text { reproducibility of graphite will need to be } \\
\text { addressed with NRC } \\
\text { Suppliers are depending upon the progression of } \\
\text { the NGNP AGC Program. }\end{array}$ \\
\hline
\end{tabular}




\begin{tabular}{|c|c|c|c|c|}
\hline Component & $\begin{array}{c}\text { Westinghouse } \\
\text { Category* }\end{array}$ & $\begin{array}{c}\text { AREVA } \\
\text { Category** }\end{array}$ & Lead Times & Notes \\
\hline Circulator $\dagger$ & A & A & 7 to 9 years & $\begin{array}{l}* / * * \text { Final design criteria needed to specify } \\
\text { components } \\
\text { *The impeller materials and coatings have been } \\
\text { given a rating of A for helium at or below } 350^{\circ} \mathrm{C} \\
\text { and a B for helium that is over } 450^{\circ} \mathrm{C} \text {, current } \\
\text { experience is } 350^{\circ} \mathrm{C} \text { and material limitation at } \\
\text { temperature may require internal cooling } \\
\text { * Motor design, active magnetic bearing (AMB), } \\
\text { electrical insulation, electrical penetrations, and } \\
\text { dry gas seals were given an A } \\
\text { Circulators up to } 6 \mathrm{MWe} \text { are within current } \\
\text { capacity }\end{array}$ \\
\hline $\begin{array}{l}\text { Helium } \\
\text { Purification } \\
\text { System }\end{array}$ & A & B & $\begin{array}{l}\text { Helium gas } 1 \text { to } \\
3 \text { months, } \\
\text { helium } \\
\text { purification } \\
\text { system } 1 \text { years }\end{array}$ & $\begin{array}{l}\text { *Have HTR German experience, can supply } \\
\text { purity at } 99.999995 \% \text {, the capacity for a single } \\
\text { reactor is sufficient } \\
\text { **Helium purification systems were produced } \\
\text { for previous HTGRs, current suppliers won't } \\
\text { have NRC approved QA programs and some } \\
\text { vendors may not want to go through the trouble } \\
\text { of getting qualified for this single project }\end{array}$ \\
\hline $\begin{array}{l}\text { Instrumen- } \\
\text { tation and } \\
\text { Controls } \dagger\end{array}$ & B & A & 4 to 6 years & $\begin{array}{l}\text { *I\&C sensors were given a rating of B: high } \\
\text { temperature sensors, helium, flow, flux sensors; } \\
\text { equipment requirements must be developed, } \\
\text { designed, manufactured, and qualified in HTGR } \\
\text { environment } \\
\text { *ISI equipment was given a rating of B: Need to } \\
\text { develop requirement, equipment designed, } \\
\text { manufactured, and qualified }\end{array}$ \\
\hline $\begin{array}{l}\text { Digital Control } \\
\text { Systems } \dagger\end{array}$ & B & B & 5 to 9 years & $\begin{array}{l}\text { *NRC approval needed, many of these issues } \\
\text { should be addressed during Gen III/III+ } \\
\text { development } \\
* * \text { Current reactors are beginning to implement } \\
\text { digital systems and it is expected that this } \\
\text { technology will mature as it receives more NRC } \\
\text { attention, this is expected to become a less } \\
\text { significant risk }\end{array}$ \\
\hline $\begin{array}{l}\text { Composite } \\
\text { Materials - } \\
\text { Core } \\
\text { Structures }\end{array}$ & A & B & Not specified & $\begin{array}{l}\text { *There are no applicable ASME code for } \\
\text { composites, materials qualification plan is } \\
\text { needed, Not NQA-1 qualified for large supplies } \\
\text { **Existing infrastructure is believed to be } \\
\text { adequate to produce require composites, } \\
\text { qualification strategy has not been developed }\end{array}$ \\
\hline $\begin{array}{l}\text { Metallic } \\
\text { Materials and } \\
\text { Internal } \\
\text { Metallics }\end{array}$ & A & B & Not specified & $\begin{array}{l}* 800 \mathrm{H} \text { max operating temperature is being } \\
\text { raised in the ASME Code, Alloy } 617 \text { is in the } \\
\text { process of being raised to } 950^{\circ} \mathrm{C} \text {. } \\
* * \text { Specifically focusing on core internals, } \\
\text { codification concerns about candidate materials }\end{array}$ \\
\hline
\end{tabular}




\begin{tabular}{|c|c|c|c|c|}
\hline Component & $\begin{array}{c}\text { Westinghouse } \\
\text { Category* }\end{array}$ & $\begin{array}{c}\text { AREVA } \\
\text { Category** }\end{array}$ & Lead Times & Notes \\
\hline $\begin{array}{l}\text { High } \\
\text { Temperature } \\
\text { Concrete }\end{array}$ & A & B & $\begin{array}{l}\text { No long lead } \\
\text { time }\end{array}$ & $\begin{array}{l}\text { *Investigation of techniques for optimizing the } \\
\text { design of structural elements is technical need } \\
\text { **Required quantities of concrete are based on } \\
\text { local shippers, which may add schedule risks or } \\
\text { may require expansion of local infrastructure }\end{array}$ \\
\hline $\begin{array}{l}\text { Fuel Handling } \\
\text { - Pebble Bed } \\
\text { Design }{ }^{\dagger}\end{array}$ & A & $\begin{array}{l}\text { Not applicable } \\
\text { to a prismatic } \\
\text { reactor }\end{array}$ & 3 to 4 years & $\begin{array}{l}\text { *Forging required, unloading device with } \\
\text { special ribbed pipes }\end{array}$ \\
\hline $\begin{array}{l}\text { RPV and } \\
\text { Large } \\
\text { Forgings } \dagger\end{array}$ & B & B & $\begin{array}{l}10 \text { years, } \\
\text { dependent on } \\
\text { demand }\end{array}$ & $\begin{array}{l}* / * * \text { Final designs needed to move forward to } \\
\text { protect schedule } \\
* \text { Making forged rings or rolled plate for vessel } \\
\text { of SA 508/533, forging and fabrication were } \\
\text { given ratings of A, a few vendors have } \\
\text { capabilities, potential for schedule delays } \\
\text { **Appears JSW is only capable vendor, early } \\
\text { ordering is critical to minimize schedule risks, } \\
\text { expecting transportation difficulties, } \\
\text { **Possible NOAK material difficulties could be } \\
\text { expected with increased ROT, forging and } \\
\text { fabrication issues are foreseen for the RPVs } \\
\text { made of Grade } 91 \text { or other less standard material }\end{array}$ \\
\hline $\begin{array}{l}\text { Core Barrel } \\
\text { with Internal } \\
\text { Support } \\
\text { Structures }\end{array}$ & B & B & 5 years & $\begin{array}{l}\text { *Core barrel is fabrication challenge, tall and } \\
\text { large diameter with thin walls. Support plate is } \\
\text { thick structure, lateral restraints \& tie rods are } \\
\text { included } \\
* * \text { Overall infrastructure should be adequate, but } \\
\text { some adjustments to produce nuclear } \\
\text { components may be required, composite } \\
\text { materials are being considered in addition to } \\
\text { metallic components }\end{array}$ \\
\hline Hot Gas Duct & $\mathrm{C}$ & $\begin{array}{l}\text { A (FOAK) } \\
\text { B (NOAK) }\end{array}$ & $\begin{array}{l}\sim 5 \text { years to } \\
\text { develop, test, \& } \\
\text { qualify at } \\
\geq 750^{\circ} \mathrm{C}\end{array}$ & $\begin{array}{l}\text { *High temperatures and high flow velocities is a } \\
\text { problem, have designed and tested a prototype } \\
\text { gas duct in South Africa at low velocities } \\
* * \text { hot duct is within the capabilities of current } \\
\text { industrial infrastructure, materials of fabrication } \\
\text { are routine, component size is not a problem for } \\
\text { current infrastructure } \\
* * \text { The NOAK was given a rating of B because } \\
\text { of the higher anticipated reactor outlet } \\
\text { temperature }\end{array}$ \\
\hline
\end{tabular}




\begin{tabular}{|c|c|c|c|c|}
\hline Component & $\begin{array}{c}\text { Westinghouse } \\
\text { Category* }\end{array}$ & $\begin{array}{c}\text { AREVA } \\
\text { Category** }\end{array}$ & Lead Times & Notes \\
\hline $\begin{array}{l}\text { Steam } \\
\text { Generator and } \\
\text { Tube Bundle } \dagger\end{array}$ & B & B & 5 years & $\begin{array}{l}\text { *SG tube bundle is different than LWR design: } \\
\text { helical coil vs. U-tube, steam generator } \\
\text { materials were given a rating of A, however } \\
\text { numerous design and fabrication challenges } \\
\text { **Development of modern fabrication } \\
\text { techniques is needed for helical coil design, } \\
\text { there may be limited numbers of vendors willing } \\
\text { to incur expense and schedule impact for a } \\
\text { FOAK plant }\end{array}$ \\
\hline $\begin{array}{l}\text { Reactor } \\
\text { Building }\end{array}$ & $\begin{array}{l}\text { Not included in } \\
\text { infrastructure } \\
\text { readiness } \\
\text { assessment }\end{array}$ & A & Not specified & $\begin{array}{l}\text { ** Once a location has been selected, it would } \\
\text { then be appropriate to make a more informed } \\
\text { decision regarding the structure, whether it be } \\
\text { fully embedded or partially embedded, which is } \\
\text { dependent on soil or rock or high water tables at } \\
\text { the location of the reactor site }\end{array}$ \\
\hline $\begin{array}{l}\text { Control Room } \\
\text { and Simulator }\end{array}$ & B & $\begin{array}{l}\text { Not included in } \\
\text { infrastructure } \\
\text { readiness } \\
\text { assessment }\end{array}$ & 5 to 9 years & $\begin{array}{l}\text { Various NRC approvals are required, Simulator } \\
\text { is NGNP-HTGR system software, the simulator } \\
\text { will be exactly like the control room }\end{array}$ \\
\hline $\begin{array}{l}\text { Reactor Cavity } \\
\text { Cooling } \\
\text { System } \dagger\end{array}$ & B & B & Not specified & $\begin{array}{l}* \text { Design is needed and testing to follow the } \\
\text { approved design } \\
* * \text { Current infrastructure is ready to provide the } \\
\text { system, there are several designs being } \\
\text { considered and they are linked to the reactor } \\
\text { building design, which has yet to be finalized }\end{array}$ \\
\hline $\begin{array}{l}\text { High } \\
\text { Temperature } \\
\text { Helium } \\
\text { Valves } \dagger\end{array}$ & B & B (NOAK) & $\begin{array}{l}7 \text { years for } \\
\text { castings, lead } \\
\text { time of } 9 \text { to } 12 \\
\text { months }\end{array}$ & $\begin{array}{l}* \text { Development is required for temperatures } \\
\text { above } 610^{\circ} \mathrm{C} \\
* \text { Addressed numerous flow control valves } \\
* * \text { High temperature helium valves are discussed } \\
\text { only for NOAK plant: high temperature valves } \\
\text { have been produced and tested in the past, but } \\
\text { new vendor will be required, this will require a } \\
\text { strong business incentive for the vendor } \\
* * \text { Addressed isolation valves }\end{array}$ \\
\hline $\begin{array}{l}\text { High } \\
\text { Temperature } \\
\text { Insulation }\end{array}$ & B & $\begin{array}{l}\text { Not included in } \\
\text { infrastructure } \\
\text { readiness } \\
\text { assessment }\end{array}$ & $\begin{array}{l}3 \text { years } \\
\text { including testing }\end{array}$ & $\begin{array}{l}\mathrm{A} 2 \mathrm{O} 3 \text { and } \mathrm{SiO} 3 \text { are ceramic fibers, } \\
\text { development need to continue to find a way to } \\
\text { successful bond these ceramic fibers long term } \\
\text { to core structures, testing is required }\end{array}$ \\
\hline $\begin{array}{l}\text { Integrated } \\
\text { Testing } \\
\text { Facility }\end{array}$ & B & $\begin{array}{l}\text { Not included in } \\
\text { infrastructure } \\
\text { readiness } \\
\text { assessment }\end{array}$ & $\begin{array}{l}4 \text { years for } \\
\text { building } \\
3 \text { years for } \\
\text { component } \\
\text { testing }\end{array}$ & $\begin{array}{l}\text { It will be necessary to test various components } \\
\text { at scale before deployment in NGNP; HTF is } \\
\text { available in South Africa }\end{array}$ \\
\hline
\end{tabular}




\begin{tabular}{|c|c|c|c|c|}
\hline Component & $\begin{array}{c}\text { Westinghouse } \\
\text { Category* }\end{array}$ & $\begin{array}{c}\text { AREVA } \\
\text { Category** }\end{array}$ & Lead Times & Notes \\
\hline $\begin{array}{l}\text { Fuel } \\
\text { Assemblies } \dagger\end{array}$ & C & $\begin{array}{l}\text { This work is } \\
\text { being } \\
\text { completed by } \\
\text { AGR program. }\end{array}$ & $>5$ years & $\begin{array}{l}\text { *NGNP fuel qualification program needs to be } \\
\text { completed } \\
\text { *Fuel particles have a rating of C and Currently, } \\
\text { there is no HTGR fuel supplier in the world that } \\
\text { has the capability to produce Pebble Bed fuel on } \\
\text { a large scale } \\
\text { **NGNP concern is the manufacturing } \\
\text { capability to manufacture subsequent fuel cores } \\
\text { after the first core } \\
\text { Suppliers are depending upon the progression of } \\
\text { the NGNP AGR Program }\end{array}$ \\
\hline $\begin{array}{l}\text { Auxiliary } \\
\text { Cooling } \\
\text { System }\end{array}$ & $\begin{array}{l}\text { Not included in } \\
\text { infrastructure } \\
\text { readiness } \\
\text { assessment }\end{array}$ & A & Not specified & \\
\hline $\begin{array}{l}\text { Intermediate } \\
\text { Heat } \\
\text { Exchanger } \\
(\mathrm{IHX}) \dagger\end{array}$ & $\mathrm{C}$ (NOAK) & $\mathrm{C}(\mathrm{NOAK})$ & $\begin{array}{l}\text { Numerous } \\
\text { design } \\
\text { alternatives } \\
\text { must be } \\
\text { resolved }\end{array}$ & $\begin{array}{l}\text { *Not applicable for FOAK, for the NOAK plant } \\
\text { the IHX design needs to be finalized } \\
\text { *IHX materials have a rating of C, ASME code } \\
\text { certification necessary, high temperature } \\
\text { corrosion issues with joining, prospective alloys: } \\
230,617,800 \mathrm{H} \text {, Hastelloy XR with Alloy } 617 \\
\text { being preferred } \\
\text { **Development needs depend on IHX type, } \\
\text { working fluid characteristics, plant operation } \\
\text { temperatures and power levels }\end{array}$ \\
\hline $\begin{array}{l}\text { QA/QC for } \\
\text { Vendors }\end{array}$ & B & B & 8 years & $\begin{array}{l}\text { *Willingness and speed of vendors to obtain } \\
\text { nuclear qualification will be dependent on } \\
\text { HTGR market, these qualifications will need to } \\
\text { be in place to prevent project delays } \\
\text { **There were no places that quality was } \\
\text { identified as an issue, due to the broad } \\
\text { development needs for industry, industry's } \\
\text { willingness to cooperate with QA requirements } \\
\text { are main issues }\end{array}$ \\
\hline Transportation & A & B & $\begin{array}{l}2 \text { years or } \\
\text { greater, } \\
\text { dependent on } \\
\text { location of the } \\
\text { site }\end{array}$ & $\begin{array}{l}\text { *Upgrades are expected to be necessary for } \\
\text { bridges and roads, a site with barge access } \\
\text { would cut lead time } \\
\text { **Delivery of some components to the plant site } \\
\text { may pose a challenge due to their size, there are } \\
\text { risks of delays with inland reactor sites which } \\
\text { would negate intact reactor vessel delivery and } \\
\text { would result in onsite fabrication, on site } \\
\text { fabrication increases costs and has the potential } \\
\text { to delay the project }\end{array}$ \\
\hline
\end{tabular}




\begin{tabular}{|l|l|l|l|l|}
\hline Component & $\begin{array}{c}\text { Westinghouse } \\
\text { Category* }\end{array}$ & $\begin{array}{c}\text { AREVA } \\
\text { Category** }\end{array}$ & \multicolumn{1}{|c|}{ Lead Times } & \multicolumn{1}{c|}{ Notes } \\
\hline $\begin{array}{l}\text { Skilled Labor } \\
\text { Force, and } \\
\text { Construction }\end{array}$ & B & B & $\begin{array}{l}\text { Construction } \\
\text { apprentice-ship } \\
\text { takes } \\
3 \text { to 5 years }\end{array}$ & $\begin{array}{l}\text { *Qualified boilermakers, pipefitters, } \\
\text { electricians, ironworkers are expected to be in } \\
\text { short supply, if NGNP is competing with more } \\
\text { than 8 LWR domestic projects, labor shortage } \\
\text { will be more severe } \\
\text { **Existing pool of workers is adequate for the } \\
\text { current production facilities and additional } \\
\text { workers will be trained for new facilities }\end{array}$ \\
\hline
\end{tabular}

$\dagger$ Indicates that this component was identified as a critical component in the NGNP TDRM [7] 


\section{CONCLUSIONS}

The objective of this report is to summarize the infrastructure readiness reports that AREVA and Westinghouse prepared and to provide additional information and considerations originating from the NGNP programs that are addressing fuels, graphite, and material R\&D. The conclusions resulting from these efforts are as follows:

- Based on the report findings by AREVA and Westinghouse and input from the NGNP Project, there will be sufficient infrastructure in place to build the FOAK plant.

- Maturing the design for the FOAK plant is essential for the placement of orders of long-lead-time components to prevent project delays. Many components have long lead times of at least 7 to 9 years. Many of the long-lead-time components are large forgings in an industry that has limited production capabilities which may lead to potential backlogs, resulting in schedule delays.

- Westinghouse pointed out that there are currently no TRISO fuel suppliers that could supply fuel for the FOAK plant and that TRISO fuel has not been qualified by the NRC. AREVA did not comment on fuel development because the NGNP Project is addressing fuel development with the AGR Fuel Development and Qualification Program. The NGNP Project concurs with Westinghouse's infrastructure readiness assessment for fuel, which was given a Readiness Level C rating, but the NGNP Project has several programs in place to address this need. AGR Fuel Development and Qualification Program, on its second of five experiments, is designed to address large-scale fuel performance, which will provide input to the development side of fuel production and data for the qualification process. The NGNP Project is also working on a demonstration with B\&W that will show the throughput for one fuel producing line. Based on that throughput, an actual requirement will be established to determine what size manufacturing process will be needed to produce fuel for the FOAK plant. The latest acquisition strategy for the AGR Fuel Development and Qualification Program is to start addressing pebble bed fuel.

- The NGNP High Temperature Materials Program is important to the NGNP Project and to suppliers because limited work is being done outside of the NGNP Project to develop the knowledge base and address the qualification issues for high temperature materials.

- A discrepancy on industry's ability to produce and machine graphite for use in the FOAK plant exists between the suppliers, which categorized graphite production at a Readiness Level A, and the NGNP Project, which identified several aspects of the graphite production process that the suppliers had not considered during their infrastructure assessment. The NGNP Graphite Development and Qualification Program was not authorized to setup and certify a graphite supplier's NQA-1 Quality Program, nor to obtain an ASME G-certificate to produce ASME nuclear grade graphite for the supplier. Additionally, per the ASME code, the plant owner is responsible for obtaining the required ASME graphite design data, based on guidance from ASTM International D-7219. Graphite machining capability must also be considered in assessing the industrial infrastructure. Developing ASME qualified machining facilities, with the capabilities and throughput needed to support a FOAK plant during its operational lifetime, are not currently being funded by graphite suppliers. ASME graphite machining facilities are required to have clean room conditions.

- Westinghouse identified the hot gas duct as requiring substantial technical development before it could be deployed, while AREVA indicated that the current level of technology for this component was sufficient for deployment. It was determined that this discrepancy on readiness of deployment for the hot gas duct is mostly because the hot gas duct was not part of Westinghouse's previous pebble bed reactor design and AREVA's reactor design did include a hot gas duct. The NGNP Project concurred with AREVA's assessment. 
- The Gen III/III+ LWRs are expected to use digital I\&C equipment, and this equipment is expected be deployed before the FOAK NGNP is constructed. Digital I\&C systems are therefore expected to be qualified by the NRC before the FOAK NGNP is deployed. 


\section{REFERENCES}

1. Heavy Manufacturing of Power Plants, World Nuclear Association, July 2010.

2. Cooper, K., Al-Fakir, W., Fabricated Forgings for Nuclear Power Applications, Nuclear Fabrication Consortium - Operated by EWI, 2010.

3. Wright, R., et al., Next Generation Nuclear Plant Reactor Pressure Vessel Material Research and Development Plan, PLN-2803, Revision 1, July 2010.

4. Wright, R., et al., Next Generation Nuclear Plant Intermediate Heat Exchanger Materials Research and Development Plan, PLN-2804, Revision 1, September 2010.

5. Windes, W., et al., Graphite Technology Development Plan, PLN-2497, Revision 1, October 2010.

6. Simonds, J., et al., Technical Program Plan for the Next Generation Nuclear Plant/Advanced Gas Reactor Fuel Development and Qualification Program, PLN-3636, Revision 0, September 2010.

7. Collins, J., Next Generation Nuclear Plant Project Technology Development Roadmaps: The Technical Path Forward for $750-800^{\circ} \mathrm{C}$ Reactor Outlet Temperature

8. Next Generation Nuclear Plant (NGNP) Prismatic HTGR Conceptual Design Project, General Atomics, NGNP-R00016, Revision 0, December 2010.

9. Effect of Reactor Outlet Helium Temperature on the Need for Composites in the NGNP, General Atomics, Report Number 911175, Revision 0, June 2009. 


\title{
Attachment 1
}

\author{
Infrastructure Readiness Assessment for Next \\ Generation Nuclear Plant, Westinghouse Electric \\ Company LLC, Report Number NGNP-PRG-GEN-RPT- \\ G-00030
}


NGNP-PRG-GEN-RPT-G-00030

Revision 1

\section{INFRASTRUCTURE READINESS ASSESSMENT FOR NEXT GENERATION NUCLEAR PLANT}

\section{APPROVALS}

\begin{tabular}{|c|c|c|}
\hline Function & Name and Signature & Date \\
\hline Author & $\begin{array}{l}\text { Ryan Hannink } \\
\text { Shaw Consultants International, Inc }\end{array}$ & $\begin{array}{l}\text { December } 31 \text {, } \\
2010\end{array}$ \\
\hline Reviewer & $\begin{array}{l}\text { Sten A. Caspersson Coperooon } \\
\text { Westinghouse Electric Compahy, LLC }\end{array}$ & $12 / 31 / 10$ \\
\hline Approval & $\begin{array}{l}\text { Edward J. Brabazon Echuldsulg } \\
\text { Shaw Environmental \& Infrastructure, Inc }\end{array}$ & $\begin{array}{l}\text { December31, } \\
\text { nolo }\end{array}$ \\
\hline
\end{tabular}

Westinghouse Electric Company LLC

Nuclear Power Plants

Post Office Box 355

Pittsburgh, PA 15230-0355

(C2011 Westinghouse Electric Company LLC

All Rights Reserved 


\section{LIST OF CONTRIBUTORS}

\begin{tabular}{|l|l|}
\hline \multicolumn{1}{|c|}{ Name and Organization } & Date \\
\hline Ryan Hannink, Shaw Consultants International & \\
\hline Westinghouse Electric South Africa Personnel & \\
\hline Westinghouse Supply Chain Management Personnel & \\
\hline & \\
\hline
\end{tabular}

\section{BACKGROUND INTELLECTUAL PROPERTY}

\begin{tabular}{|c|c|c|}
\hline SECTION & TITLE & Description \\
\hline NONE & & NONE \\
\hline
\end{tabular}




\section{RECORD OF CHANGES}

\begin{tabular}{|c|l|l|c|}
\hline $\begin{array}{c}\text { Revision } \\
\text { No. }\end{array}$ & \multicolumn{1}{|c|}{ Revision Made By } & \multicolumn{1}{|c|}{ Description } & Date \\
\hline 1 & Sten A. Caspersson & $\begin{array}{l}\text { Respond to BEA } \\
\text { comments }\end{array}$ & $12 / 31 / 2010$ \\
\hline & & & \\
\hline & & & \\
\hline
\end{tabular}

\section{DOCUMENT TRACEABILITY}

\begin{tabular}{|c|c|c|}
\hline $\begin{array}{c}\text { Created to support the following } \\
\text { Document(s) }\end{array}$ & Document Number & Revision \\
\hline NONE & & NONE \\
\hline
\end{tabular}




\section{EXECUTIVE SUMMARY}

For the Nuclear Energy Advisory Committee (NEAC) "first project phase review," an item of interest will be assessing the current HTGR infrastructure capability, to identify development needs and recommend additional improvements required to support deployment of the NGNP, which could also apply to the deployment of follow-on high temperature gas-cooled reactors (HTGRs).

This Infrastructure Readiness Assessment examines the current state and plans to address the various infrastructure elements necessary to support deployment of NGNP. It focuses on the actual infrastructure for construction and start of operations for an NGNP, with an understanding that the same infrastructure could be brought to bear on future HTGR deployment.

An NGNP Infrastructure Readiness Assessment Matrix provides a list of the 36 infrastructure areas that must be considered when evaluating the readiness of the NGNP for deployment in the 2020+ timeframe. This matrix builds on previous ALWR and HTGR work. Information summarized in the matrix includes current capacity, technology development needs, and lead time. Suppliers are also included.

In order to give a general indication of the most critical infrastructure needs the areas were sorted into three categories. The three categories of needs in the matrix are $\mathrm{A}, \mathrm{B}$, and $\mathrm{C}$, which are generally defined as:

- Category A: Not a Significant Problem. These areas are primarily Gen III / III+ generic nuclear areas, or items which have been proven in and provided for prior HTGR construction.

- Category B: Obtainable with Advanced Planning. These items require technology development, testing, fabrication confirmation, long lead times or infrastructure expansion.

- Category C: Significant Infrastructure and/or Technical Development Required. These three (3) items require technology development and / or qualification and an adequate vendor base.

A summary of how the items in the matrix are categorized is provided in Table 1, specific to NGNP as a FOAK (first-of-a-kind) concept with an outlet temperature of 750C. This table also applies to NOAK (Nth-of-a-kind) plants with outlet temperatures of $750 \mathrm{C}$. 


\section{Table 1. Summary of NGNP Infrastructure Needs Categories}

\begin{tabular}{|c|c|c|}
\hline Category A & Category B & Category $\mathbf{C}$ \\
\hline $\begin{array}{ll}\text { - } & \text { Pressure Vessel } \\
\text { - } & \text { Pressurication Options } \\
\text { - } & \text { Cross Vessel/Major Piping } \\
\text { - } & \text { Steam Generator Materials } \\
\text { - } & \text { Construction Capabilities } \\
& \text { \& Techniques } \\
\text { - } & \text { Fuel Handling (Pneumatic- } \\
\text { - } & \text { Pebble) } \\
\text { - } & \text { Metallic Materials } \\
\text { - } & \text { Composite Materials } \\
\text { - } & \text { Graphite Raw Material } \\
\text { - } & \text { Core Ceramic Structures } \\
\text { - } & \text { Lateral Restraints \& Tie } \\
& \text { Rods } \\
\text { - } & \text { High Temperature } \\
& \text { Concrete } \\
\text { - } & \text { Rankine Cycle Steam } \\
& \text { Plant } \\
\text { - } & \text { Burnup Measurement } \\
\text { - } \text { Pebble) } \\
\text { - } \text { Controlium Rod System }\end{array}$ & $\begin{array}{ll}\text { - } & \text { RPV / Large Forgings / } \\
& \text { Nozzle Forgings } \\
\text { - } & \text { Core Barrel (w/Support } \\
& \text { Plate and Top Plate) } \\
\text { - } & \text { Steam Generator } \\
\text { - } & \text { Steam Generator Tube } \\
& \text { Bundle } \\
\text { - } & \text { Circulators } \\
\text { - } & \text { I\&C Systems } \\
\text { - } & \text { Simulator } \\
\text { - } & \text { Control Room } \\
\text { - } & \text { Integrated Testing } \\
\text { - } & \text { High Temperature Helium } \\
& \text { Valves } \\
\text { - } & \text { QA / QC Programs for } \\
& \text { HTGR Vendors } \\
\text { - } & \text { Ceramic Materials } \\
\text { - } & \text { High Temperature } \\
\text { - Insulation } & \text { I \& C Sensors } \\
\text { - } & \text { ISI Equipment } \\
\text { - } & \text { RCCS } \\
\text { - } & \text { Skilled Labor Force } \\
\text { Bellows }\end{array}$ & $\begin{array}{ll}\text { - } & \text { Fuel Assemblies (Pebbles) } \\
\text { and Particles } \\
\text { - } \\
\text { - } & \text { IHXct Liner / Hot Gas Duct } \\
& \text { IHX Materials }\end{array}$ \\
\hline
\end{tabular}

Overall, the majority of the issues identified in this report can be addressed with advanced planning. Items specific to HTGR technology and the NGNP will provide some unique challenges; however, none seem insurmountable for the current NGNP timeframe if assigned sufficient priority and resources. 
Primary conclusions and recommendations of this report include:

- Fuel: At the present time, there is no HTGR fuel supplier in the U.S. (or worldwide) that has the capability to produce $\mathrm{UO}_{2} / \mathrm{UCO}$ fuel particles or assemblies / pebbles on a large scale for NGNP.

- Steam Generator: Since the NGNP steam generator is a one-per-unit component (like the circulator) it is most likely that a single supplier will need to be qualified for NGNP, without the assurance of near term additional orders.

- Helium Circulator: An operating regime for the NGNP main circulator must be defined and the qualification of material characteristics in the defined environment must be started. Specific design evaluations must be made (such as the relative merits of dry gas seals versus the challenges of the submerged motor and electrical penetrations) and material aging benchmark testing must start as soon as possible.

- Nuclear Quality Assurance (QA) and Quality Control (QC): Overall the nuclear QA/QC programs are developed and available for use on an NGNP, even the items that are particular to HTGR technology and NGNP. The major exception is graphite, which still requires some code and program development on the part of ASME and the vendors. At least one graphite manufacturer needs to be qualified to produce graphite to the new ASME Boiler and Pressure Vessel Code Section III Division 5. Because it is so critical to the project, the NGNP program should ensure that at least one graphite manufacturer receives authorization by ASME to complete this work.

- Large Forgings: The capability to supply the very large forgings required for the NGNP plant is available, particularly for the SA 508/533 material proposed for the FOAK plant. Because of stiff competition from other nuclear projects around the world, the tight capacity has led to very long lead times. Although expansions of this capacity could improve the situation, it is still advisable to plan far in advance and place an order within a few years to ensure delivery in time for NGNP plant construction.

- Instrumentation and Controls (I\&C): Similar to LWRs, design and NRC approval of digital plant control systems will be time consuming. All I\&C used for the NGNP should be standard Nuclear Power Plant technology. Environmental Qualification (EQ) of some instrumentation may be required due to specific NGNP environmental conditions and requirements.

- High Temperature Materials: At present there is no applicable ASME code for ceramic materials, composites, or Hastelloy X/XR. A Materials Qualification Plan will need to be developed for specific materials, dependent on design and application. Material $\left(\mathrm{Al}_{2} \mathrm{O}_{3}\right.$ 
\& $\mathrm{SiO}_{2}$ ceramic fibers) for high temperature insulation is commercially available; however, development is necessary to integrate ceramic fibers into a successful insulation design (current design solutions are sufficient for short/medium term but will probably not survive a 60 years lifetime requirement).

- Helium Valves: Operating temperatures will be a deciding factor in how difficult it is to fabricate and qualify helium valves. High temperature gas reactor designs so far have elected to reduce the necessity of having valves at reactor outlet temperatures. With careful design selection the high temperature challenges on valves may be avoided.

- Skilled Labor: Qualified boilermakers, pipefitters, electricians, and ironworkers are expected to be in short supply in local labor markets. For the Idaho FOAK site in particular, the use of traveling workers from other states/communities will be required. If the NGNP is competing with more than 8 other LWR domestic units under construction at the same time, the labor shortage will be more severe; however, if there are less than 8 other units under construction the labor shortage could be less severe.

The recommended path forward for NGNP includes activities associated with early completion of critical design work, technology development, standards development, and testing and qualification of important items. Many essential activities cannot start until sufficient design work has been completed. Completing sufficient design work early in the process will allow time and resources to be focused on technology development in critical areas that can be identified as the design progresses. These include placing forging orders, and development of the helium circulator, helium valves, and sensors in order to resolve technology issues.

Important to technology development efforts is QA/QC program development and standard development, which includes testing and qualification. In order to ensure that the NGNP plant can be built without schedule delays due to rework, all of the primary organizations, including the NRC, utility, nuclear system vendors, component suppliers, material suppliers, and EPC contractors, must ensure that nuclear QA/QC programs are properly in place for all phases of the project, starting with design and fabrication, with particular focus on HTGR-specific vendors that do not have previous nuclear QA/QC experience.

A nuclear graphite $\mathrm{QA} / \mathrm{QC}$ code and accreditation program needs to be developed such that nuclear graphite QA/QC programs can be certified. The NGNP project should coordinate with graphite vendors and ASME/National Board to ensure that such programs will be in place in time for NGNP deployment. The NGNP program should ensure that at least one supplier is authorized to supply graphite core components to the new ASME code Division 5 requirements.

The NGNP Fuel Qualification Program should be completed and subsequently a fuel fabrication facility should be qualified. 
Critical areas include: steam generator testing and fabrication including bending and welding, testing of high temperature insulation for long life service, testing and environmental qualification of sensors, instrumentation, and controls, and testing and ASME code development of ceramic material, composites and Hastelloy X/XR.

In order for the NGNP project to proceed on schedule numerous critical activities must be planned and started in the near term because of the long lead times associated with certain activities. These include:

- Reactor Pressure Vessel - 10 years

- Circulator -7 years

- I\&C Systems / Simulator / Control Room - 5 to 9 years

- Fuel Fabrication Facility - Not known; > 5 years

- Castings (for Valves) - 7 years

- QA/QC Programs for HTGR Vendors - 8 years

- ISI Equipment - 4 to 6 years

- Duct Liner / Hot Gas Duct - 5 years

- Graphite Raw Material - 5 to 10 years 


\section{TABLE OF CONTENTS}

EXECUTIVE SUMMARY .................................................................................................... 4

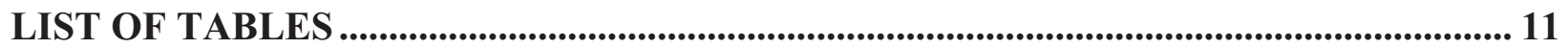

LIST OF FIGURES ................................................................................................................. 12

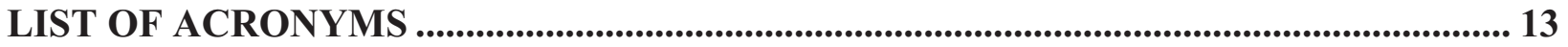

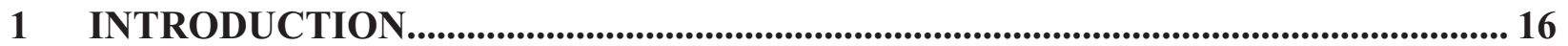

2 SCOPE, OBJECTIVES AND REQUIREMENTS ..................................................... 18

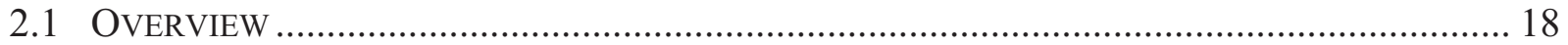

2.2 BACKGROUND AND REFERENCE DOCUMENTS TO BE CONSIDERED ................................. 18

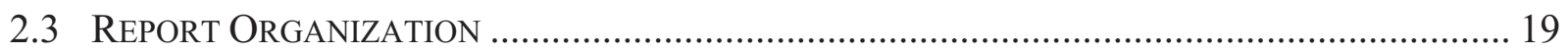

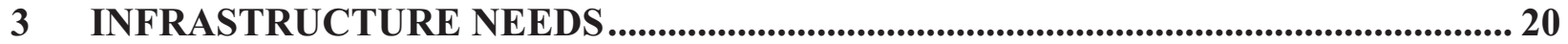

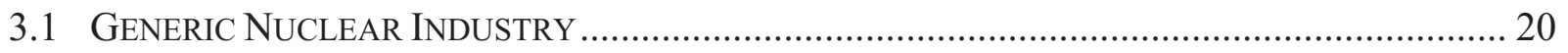

3.2 HTGR/NGNP SPECIFIC NEEDS ........................................................................ 21

3.3 PATH FORWARD FOR NGNP PROJECT ..................................................................... 22

4 SELECTED PRIORITY NGNP INFRASTRUCTURE NEEDS .................................. 24

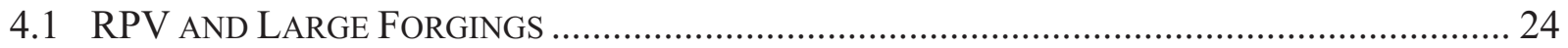

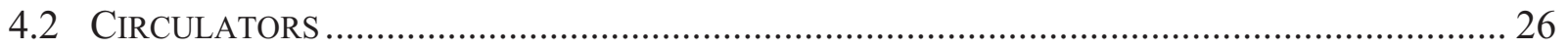

4.3 FuEL ASSEMBLIES AND FUEL PARTICLES ............................................................... 31

4.4 High TEMPERATURE HELIUM VALVES ...................................................................... 32

4.5 NuClEAR QA/QC PROGRAMS .................................................................................. 37

4.6 Graphite Core Components ANd RAW MATERIAL ................................................... 40

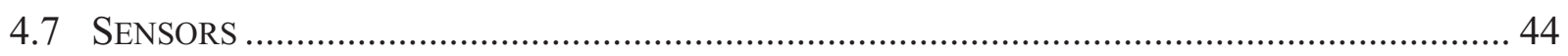

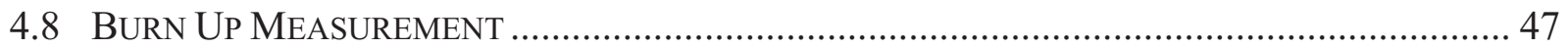

4.9 Core Barrel, SteAm Generator And SteAm Generator BundLE.......................... 48

5 NGNP INFRASTRUCTURE READINESS ASSESSMENT MATRIX....................... 58

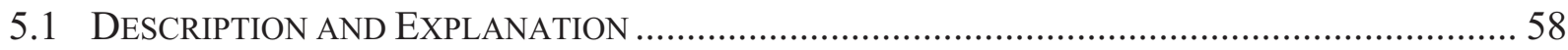

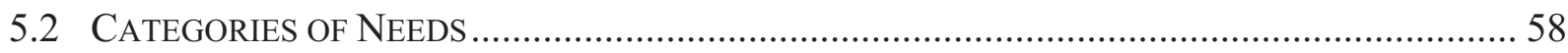

5.3 NGNP INFRASTRUCTURE READINESS ASSESSMENT MATRIX .......................................... 60

6 CONCLUSIONS AND RECOMMENDATIONS FOR NGNP .................................... 77

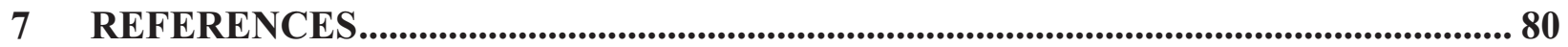

APPENDIX A. HELIUM TEST FACILITY PROCUREMENT EXPERIENCE AND LESSONS LEARNED ................................................................................................................. 83

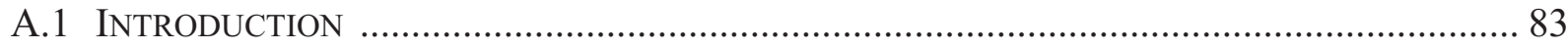




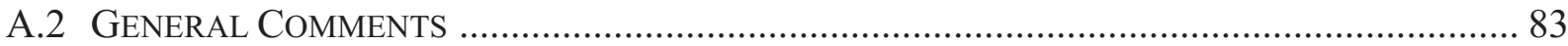

A.3 Summary of Procurement EXPERIENCE PER HTF SERVICE/COMMODITY ..................... 85

APPENDIX B. SUPPLY CHAIN MANAGEMENT LESSONS LEARNED FROM GEN

III+ REACTOR DEPLOYMENT .......................................................................................... 89

APPENDIX C. WESTINGHOUSE EXPERIENCE WITH HELIUM CIRCULATORS ... 90

APPENDIX D. NUCLEAR RENAISSANCE: IMPACT ON INFRASTRUCTURE............ 96 


\section{LIST OF TABLES}

Table 1. Summary of NGNP Infrastructure Needs Categories ............................................. 5

Table 2. Helium Valves for the 400 MWt PBMR ....................................................................... 32

Table 3. Helium Valves for the Helium Test Facility .............................................................. 33

Table 4. Fuel Handling Valves (Process Elements) with Fuel Spheres Passing Through........... 33

Table 5. Fuel Handling Helium Valves Imbedded in Valve Blocks......................................... 33

Table 6. Vendors Used in the HTF Construction ................................................................ 35

Table 7. Key Properties - Graphite Feedstock for Core Components..................................... 44

Table 8. MHTGR vs. Large PWR Major Component Dimensions and Masses ........................ 57

Table 9. Summary of Infrastructure Needs Categories...................................................... 59

Table 10. NGNP Infrastructure Readiness Assessment Matrix ................................................. 60 


\section{LIST OF FIGURES}

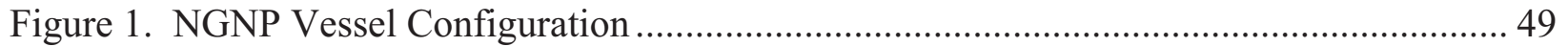

Figure 2. PWR-MHTGR RPV-SG Comparison............................................................... 50

Figure 3. Typical Modular HTGR Steam Generator Configuration ....................................... 53

Figure 4. HTGR Steam Generator Helical Coil Bundle .................................................... 54

Figure 5. Comparison of MHTGR / NGNP vs. Large LWR Major Components ...................... 56

Figure C-1. A Fan Configuration (High Flow, low head) versus a Centrifugal Configuration (High Head at low flow)..... 


\section{LIST OF ACRONYMS}

\begin{tabular}{|l|l|}
\hline \multicolumn{1}{|c|}{$\begin{array}{c}\text { Abbreviation or } \\
\text { Acronym }\end{array}$} & \\
\hline ALWR & $\begin{array}{l}\text { Advanced Light Water Reactor (AP1000, EPR, ABWR, Gen III and Gen } \\
\text { III+; the "Nuclear Renaissance") }\end{array}$ \\
\hline AFL-CIO & American Federation of Labor and Congress of Industrial Organizations \\
\hline AGR & Advanced Gas Reactor \\
\hline ANSI & American National Standards Institute \\
\hline ASME & American Society of Mechanical Engineers \\
\hline AMB & Automatic Magnetic Bearings \\
\hline BUMS & Burn Up Measurement System \\
\hline CB & Core Barrel \\
\hline COTS & Commercial Off The Shelf \\
\hline CSI & Core Structures Instrumentation \\
\hline dP & differential Pressure \\
\hline DGS & Dry Gas Seals \\
\hline EQ & Environmental Qualification \\
\hline ENSA & Equipos Nucleares, S.A. \\
\hline FOAK & First of a kind \\
\hline FRM & Fuel Fabrication Raw Materials \\
\hline GA & General Atomics \\
\hline GCC & Graphite Core Components \\
\hline HVAC & Heating, Ventilation and Air Conditioning \\
\hline HPS & Helium Purification System \\
\hline HTF & Helium Test Facility \\
\hline HTGR & High Temperature Gas Reactor \\
\hline INL & Idaho National Laboratory \\
\hline ISI & In Service Inspection \\
\hline ICHMI & Instrumentation, Controls and Human Machine Interface \\
\hline IP & Intellectual Property \\
\hline IHX & Intermediate Heat Exchanger \\
\hline ICACC & International Conference on Advanced Ceramics \& Composites \\
\hline ISO & International Organization for Standardization \\
\hline I\&C & Instrumentation and Controls \\
\hline IHI & Ishikawajimi-Harima Heavy Industries \\
\hline JSW & Japan Steel Works \\
\hline LWR & Light Water Reactor \\
\hline & \\
\hline
\end{tabular}




\begin{tabular}{|c|c|}
\hline $\begin{array}{c}\text { Abbreviation or } \\
\text { Acronym }\end{array}$ & Definition \\
\hline MI & Mineral insulated \\
\hline MHI & Mitsubishi Heavy Industries \\
\hline MHTGR & Modular High Temperature Gas-cooled Reactor \\
\hline NGNP & Next Generation Nuclear Plant \\
\hline NOAK & $\mathrm{N}^{\text {th }}$ of a kind \\
\hline NIS & Nuclear Instrumentation System \\
\hline NPP & Nuclear Power Plant \\
\hline NQA-1 & Nuclear Quality Assurance 1 Standard \\
\hline $\mathrm{NRC}$ & Nuclear Regulatory Commission \\
\hline OSHA & Occupational Health and Safety \\
\hline OEM & Original Equipment Manufacturer \\
\hline PBMR & Pebble Bed Modular Reactor \\
\hline PAMS & Post Accident Mitigation System \\
\hline $\mathrm{PB}$ & Pressure Boundary \\
\hline PWR & Pressurized Water Reactor \\
\hline QA & Quality Assurance \\
\hline QC & Quality Control \\
\hline RCS & Reactivity Control System \\
\hline RCCS & Reactor Cavity Cooling System \\
\hline ROT & Reactor Outlet Temperature \\
\hline RPB & Reactor Pressure Boundary \\
\hline RPV & Reactor Pressure Vessel \\
\hline$R \& D$ & Research and Development \\
\hline RSS & Reserve Shutdown System \\
\hline SAS & Small Absorber Spheres \\
\hline SOW & Statement of Work \\
\hline SG & Steam Generator \\
\hline SGB & Steam Generator Bundle \\
\hline SGV & Steam Generator Vessel \\
\hline SR & Source Range \\
\hline $\mathrm{T}$ & Temperature \\
\hline TRL & Technology Readiness Level \\
\hline $\mathrm{V} \& \mathrm{~V}$ & Verification and Validation \\
\hline WEC & Westinghouse Electric Company \\
\hline
\end{tabular}


NGNP-PRG-GEN-RPT-G-00030

Infrastructure Readiness Assessment

Revision 1 for Next Generation Nuclear Plant

\begin{tabular}{|l|l|}
\hline $\begin{array}{c}\text { Abbreviation or } \\
\text { Acronym }\end{array}$ & \multicolumn{1}{c|}{ Definition } \\
\hline WESA & Westinghouse South Africa \\
\hline WNA & World Nuclear Association \\
\hline
\end{tabular}




\section{INTRODUCTION}

For the Nuclear Energy Advisory Committee (NEAC) "first project phase review," an item of interest will be assessing the current HTGR infrastructure capability, to identify development needs and recommend additional improvements required to support deployment of the NGNP, which could also apply to the deployment of follow-on high temperature gas-cooled reactors (HTGRs).

This Infrastructure Readiness Assessment examines the current state and plans to address the various infrastructure elements necessary to support deployment of NGNP, mostly focusing on industrial capabilities. It focuses on the actual infrastructure for construction and start of operations for an NGNP, with an understanding that the same infrastructure could be brought to bear on follow-on HTGR deployment.

Specific topics addressed in the infrastructure assessment include:

A. Ability of suppliers to provide equipment and materials of construction and/or fabricate NGNP components. This includes metallic, graphitic and ceramic materials of construction. Potential suppliers are identified.

B. Ability of suppliers to perform in accordance with an NQA-1 quality program.

C. Transportation capability for moving the equipment and materials in their appropriate shapes and sizes.

D. Readiness level of skilled labor forces needed to accomplish the various phases of manufacturing/fabrication, construction, transportation and start-up.

E. Availability of construction capabilities and techniques necessary to build an NGNP.

The process followed to conduct the assessment had several steps:

1. A matrix of infrastructure needs was created of the 36 infrastructure areas that must be considered when evaluating the readiness of the NGNP for deployment in the 2020+ timeframe.

2. Infrastructure needs were categorized as:

A- Not a Significant Problem

B- Obtainable with Advanced Planning, or

C- Significant Infrastructure and/or Technical Development Required

3. Detailed write-ups of key issues were prepared, to clarify the issues. 
4. The most recent HTGR related procurement experience was for the Helium Test Facility in South Africa. This experience was therefore factored into the assessment.

5. The results were reviewed by Westinghouse Gen III+ Supply Chain Management personnel, in those areas which are generic to the nuclear industry.

This report is organized around the Infrastructure Readiness Assessment matrix in Section 5 (the "matrix"), plus the individual write-ups in Section 4.

Recommended high level paths forward by need are given, as well as Conclusions and Recommendations for the NGNP project. 


\section{SCOPE, OBJECTIVES AND REQUIREMENTS}

\subsection{Overview}

The scope of this study was to assess the ability of suppliers to provide the equipment and materials and to fabricate the components necessary to build and operate an NGNP. The scope also included an assessment of the nuclear Quality Assurance (QA) and Quality Control (QC) programs of the suppliers, an assessment of the readiness level of the skilled labor forces needed for manufacture/fabrication, construction, transportation, and start-up, and an assessment of the capability to transport and construct an NGNP.

Both first of a kind (FOAK) and nth of a kind (NOAK) NGNPs were considered, with more emphasis on the FOAK NGNP. Because detailed studies have previously been done on generic nuclear issues, more emphasis was placed on NGNP-specific issues.

This deliverable has two major sections. The first is a NGNP Infrastructure Readiness Assessment Matrix, which is intended to be comprehensive and touch on all of the areas that could potentially be issues. This matrix also acts as a screening device from which some areas are selected for more detailed discussion. These areas are included in the second major section of the deliverable, the Selected Priority NGNP Infrastructure Needs/Status/Capabilities section. These areas were selected for more detailed discussion because of their importance to the onschedule completion of an NGNP and because of their specificity to HTGR technology and the NGNP.

\subsection{Background and Reference Documents to be Considered}

This report will provide input to the Nuclear Energy Advisory Committee (NEAC) on its "first project phase review" of the NGNP project as required by the Energy Policy Act of 2005.

As indicated in the Scope of Work, this report builds upon prior studies that have been conducted for NGNP. In particular, the MPR report, "DOE NP2010 Nuclear Power Plant Construction Infrastructure Assessment" is intended to be a reference and a companion document to this report. It covers the infrastructure readiness issues for ALWR plants, while this report focuses on the issues specific to HTGRs but references the MPR report for generic nuclear issues common to ALWRs and HTGRs. A full listing of the references is included in Section 7. 


\subsection{Report Organization}

This report discusses the infrastructure needs for a generic nuclear project and specifically for an NGNP in Section 3. A detailed discussion of specific infrastructure needs is included in Section 4. These specific needs were identified by the comprehensive matrix included in Section 5. Conclusions and recommendations for the NGNP project are discussed in Section 6. 


\section{INFRASTRUCTURE NEEDS}

\subsection{Generic Nuclear Industry}

As detailed in the MPR report, DOE NP2010 Nuclear Power Plant Construction Infrastructure Assessment (Reference 13), in regard to the deployment of Gen III+ units, "the necessary manufacturing, fabrication, labor, and construction equipment infrastructure is available [as of 2005] or can be readily developed to support the construction and commissioning of up to eight nuclear units during the period from 2010 to 2017." The MPR report also identified several areas where the infrastructure and available resources are limited. These areas were:

- digital plant control systems and plant simulators (particularly NRC procedures and regulations),

- reactor pressure vessel nuclear-grade large ring forgings,

- qualified personnel (particularly qualified boilermakers, pipefitters, electricians, ironworkers, health physicists, operators, and maintenance personnel, as well as nuclear QA/QC programs)

- material procurement (nuclear-grade metals)

These issues are generic to the nuclear industry and thus apply not only to Gen III + deployment but to an NGNP as well. For the areas in which development work needs to be done to establish the appropriate infrastructure (such as NRC procedures and regulations), the Gen III+ experience will be beneficial to NGNP and because the timing of NGNP implementation is behind the first wave of Gen III+ plants these infrastructure needs should be addressed prior to NGNP deployment. For those areas in which the infrastructure is resource-limited (such as forgings, qualified personnel, and material procurement), an NGNP could face competition from Gen III+ projects. However, one should also keep in mind that the expansion of these resource-limited infrastructure areas in anticipation of the first wave of Gen III+ projects will be beneficial to all subsequent nuclear projects.

Other issues that are generic to the nuclear industry but are not expected to be significant problems include transportation, construction capabilities and techniques (including modularization), and the Rankine steam cycle. These items do have lead times and may require some advanced planning and design work for the specific reactor and location. However, these problems are similar to those one encounters in developing any nuclear project and thus are not the focus of this report. 


\subsection{HTGR/NGNP Specific Needs}

Issues that are specific to HTGR/NGNP are the focus of this report. These items include:

- Helium circulators

- Fuel assemblies and fuel particles

- Fuel handling systems (pneumatic for pebbles)

- Helium valves

- Nuclear QA/QC for HTGR vendors

- Graphite core components and raw material

- High temperature sensors

- Steam generator materials and tube bundle (helium to steam)

- Core barrel (with support plate and top plate)

- HTGR simulator and control room

- HTGR I\&C systems

- HTGR ISI equipment

- Reactor Cavity Cooling System (RCCS)

- Duct liner/hot gas duct

- Bellows (hot duct sections and RPV to cross duct)

- Lateral restraints and tie rods

- High temperature concrete

- Burn up measurement

- Helium

- Reserve Shutdown System (RSS)

- Small Absorber Spheres (SAS)

- Control rod system (reactivity control system)

- IHX (for NOAK applications)

These HTGR items will not be addressed by ALWR infrastructure development efforts and thus efforts must be made to develop the infrastructure specifically for the NGNP project. Of these items, the ones that are the most critical and will require advanced planning and possibly technology development include:

- Helium circulators

- Fuel assemblies and fuel particles

- High temperature Helium valves

- Nuclear QA/QC for HTGR vendors

- ASME Code for Graphite Core Components

- Sensors 
- Steam generator and tube bundle (helium to steam)

- Core barrel (with support plate and top plate)

- Duct liner / Hot gas duct

- I\&C systems

- Simulator

- Control room

- Integrated testing

- Ceramic materials

- IHX (for NOAK)

Many of these critical items include technology development work, testing, standards development and other infrastructure development efforts that require advanced planning. Section 4 includes a detailed discussion of critical items.

\subsection{Path Forward for NGNP Project}

In order for the NGNP project to proceed on schedule numerous critical activities must be planned and started in the near term because of the long lead times associated with certain activities.

Many critical activities cannot start until sufficient design work has been completed. The design of the large pressure vessels need to be sufficiently finalized to specify the forgings and an order placed with a large forger within a few years. The design requirements objectives of the helium circulators need to be established as soon as possible so that the appropriate bench scale material and component testing can be initiated and the most appropriate circulator concept and vendor partners can be selected. The design requirements objectives of the helium valves and sensors also need to be established as soon as possible so that potential valve vendors can be engaged early enough to ensure that technology issues can be adequately resolved.

Completing sufficient design work early in the process will also allow time and resources to be focused on technology development in critical areas that can be identified as the design progresses. For example, depending on the core barrel design some technology development in the welding of thin sections may be required. The duct liner/hot gas duct may require material technology development if the temperature exceeds $750^{\circ} \mathrm{C}$ and approaches $950^{\circ} \mathrm{C}$. High temperature insulation material in the form of ceramic fibers may be commercially available but some technology development will still be required to successfully integrate ceramic fibers into an appropriate insulation design. 
Important to technology development efforts is QA/QC program development and standard development, which includes testing and qualification. In order to ensure that the NGNP plant can be built without schedule delays due to rework, all of the primary organizations, including the NRC, utility, nuclear system vendors, component suppliers, material suppliers and EPC contractors, must ensure that nuclear $\mathrm{QA} / \mathrm{QC}$ programs are properly in place for all phases of the project, starting with design and fabrication, with particular focus on HTGR-specific vendors that do not have previous nuclear QA/QC experience.

A nuclear graphite $\mathrm{QA} / \mathrm{QC}$ code and accreditation program needs to be developed such that nuclear graphite QA/QC programs can be certified. The NGNP project should coordinate with graphite vendors and the ASME/National Board to ensure that such programs will be in place in time for NGNP deployment. The NGNP program should ensure that at least one supplier is authorized to supply graphite core components to the new ASME code Division 5 requirements. In addition the NGNP Fuel Qualification Program should be completed and subsequently a fuel fabrication facility should be qualified. Critical areas include: steam generator testing and fabrication including bending and welding, testing of high temperature insulation for long life service, testing and environmental qualification of sensors, instrumentation, and controls, and testing and ASME code development of ceramic material, composites, and Hastelloy X/XR. 


\section{SELECTED PRIORITY NGNP INFRASTRUCTURE NEEDS}

Critical NGNP infrastructure needs were identified based on the initial screening provided by the NGNP Infrastructure Readiness Assessment Matrix included in Section 5. The critical areas that warrant more discussion than provided in the matrix are included in this section. These selected areas include:

- RPV and Large Forgings

- Circulators

- Fuel Assemblies and Fuel Particles

- High Temperature Helium Valves

- Nuclear QA/QC Programs

- Graphite Core Components and Raw Material

- Sensors

- Core Barrel, Steam Generator, and Steam Generator Bundle

Notably, the IHX and Duct Liner / Hot Gas Duct were not selected for further discussion in this section because they are well known technology development needs that are being studied in detail in other efforts. The IHX is also an NOAK item and is not critical to the FOAK NGNP which is the primary focus of this assessment.

\subsection{RPV and Large Forgings}

RPV and large forgings correspond to Item $1 \mathrm{~b}$ in the matrix.

\subsubsection{Description}

Large nuclear pressure vessels, such as the reactor pressure vessel and steam generator vessel, are fabricated from either ring and head forgings or welded rolled plates. Forgings require less welding and fewer subsequent non-destructive examinations than welded rolled plates. The weight and dimensions of the forgings, however, may cause transportation difficulties for the FOAK site at Idaho National Laboratory, which is not accessible by barge but instead only by road. For sites that are not accessible by barge, it may be necessary to ship rolled and formed sub-assemblies of the reactor pressure vessel to the site for final assembly.

The need in the large forgings area is for manufacturing facilities that can handle the required vessel diameters, heights and weights. The limiting factors in manufacturing large forgings include ingot size (which have different size and weight limits depending on the material), the dimensions of the round furnace, and the dimensions of the quench tank. 
The technology to produce very large forgings is available at a very limited number of suppliers for SA 508/533, which is both standard LWR material and the FOAK NGNP pressure vessel material. For the Mod 9Cr-1Mo (Grade 91) material that potentially could be used for the NOAK pressure vessel material, some further technology development is needed to solve the segregation issue, which makes it difficult to make homogenous ingots and limits the ingot weight to less than what would be needed to produce the NGNP reactor pressure vessel forgings.

The lead time for very large forgings includes reservations at the supplier five to six years in advance and an additional three to four years to produce the final product (includes the time for manufacturing of the forgings as well as the time for nuclear qualified fabricators to weld, assemble and certify the final product).

The NGNP reactor is larger in diameter and height than conventional light water reactors. The technology needs and bottlenecks, however, are similar to those of conventional light water reactors.

\subsubsection{Status}

The predominant manufacturer of very large nuclear forgings is Japan Steel Works (JSW). JSW is the world leader in producing forgings of the size that would be needed for the NGNP reactor pressure vessel. Other very large forging capacity is in operation in China (China First Heavy Industries and China Erzhong) and Russia (OMZ Izhra), while new capacity is being built in Japan, China, South Korea, France, the Czech Republic and Russia.

The capacity, particularly at JSW, is in tight supply because of the large number of Gen III/III+ reactors that are being planned, as evidenced by the very long advance reservation waiting period. If a significant number of Gen III/III+ projects are delayed or cancelled then the shortage of capacity could ease. The expansions of capacity that are being completed at JSW and in other countries around the world should help ease the capacity shortage; however, if competition again increases with a renewed worldwide push for nuclear energy, capacity could easily remain in short supply and lead times could remain long.

Forgers perform the prefabrication of nuclear vessel components, while the welding and fabrication of these components into the final products (as well as intermediate subassemblies) are conducted by heavy industry companies such as Toshiba, Ansaldo Camozzi, Doosan Heavy Industries, Equipos Nucleares, S.A. (ENSA), Hitachi, Ishikawajimi-Harima Heavy Industries (IHI), and Mitsubishi Heavy Industries (MHI). Potential US suppliers include American Tank and Fabrication, Nuclear - Cleveland, OH, Precision Custom Components - York, PA, and Newport News, VA - AREVA Consortium, Chicago Bridge and Iron. These companies perform 
the certifications of the nuclear components and have the overall responsibility for the nuclear QA/QC program.

\subsubsection{Path Forward for NGNP}

In order to ensure delivery of the large pressure vessels in time for NGNP plant construction, the design of these components should be sufficiently finalized to specify the forgings and an order placed with a large forger within a few years. The NGNP project needs to work with the forger to ascertain the delivery schedule of the forgings to the vessel fabricators. Vessel fabricators also need to be coordinated in order to ensure that the completed components will be on site in time for construction. For the FOAK site at INL this coordination is essential as transportation constraints may necessitate shipping subassemblies to the site for final assembly.

\subsubsection{Conclusions and Recommendations for NGNP Project}

Overall, the capability to supply the very large forgings required for the NGNP plant is available, particularly for the SA 508/533 material proposed for the FOAK plant. Because of stiff competition from other nuclear projects around the world, the tight capacity has led to very long lead times. Although expansions of this capacity could improve the situation, it is still advisable to plan far in advance and place an order within a few years to ensure delivery in time for NGNP plant construction.

\subsection{Circulators}

Circulators correspond to Item 4 in the matrix.

\subsubsection{Description}

The exact nature of the NGNP helium circulators are only defined in very broad terms, moving $\mathrm{X} \mathrm{kg} / \mathrm{s}$ helium through an estimated circuit resistance, and hence yielding a circulator power of $\mathrm{Y}$ MW.

Circulators are volume devices, and given that the primary coolant is to be helium, with a relatively low density, the circulators will move large volumes of gas, with relatively low pressure ratios, requiring low levels of maintenance, and the solution will therefore more likely be fan/compressor type designs, as opposed to positive displacement devices. The technology driving aerodynamic design of impellers is mature, so the real challenge of helium is its very high temperature, its ability to absorb into materials, and its dielectric properties, especially once 
contaminated with graphite dust. Decarburization at high temperature may pose a new unquantified material risk.

Irrespective of the type of circulator, it needs an impeller, a motor to drive it, and a vessel to contain the pressure. If you drive a rotor, you need bearings to support it, and the motor needs power and cooling. At this point the solution deviates substantially in outcome. The solution can opt to submerge the motor-bearings in helium (direct drive), which means that power and cooling water need to penetrate the containing vessel. The alternative concept is to only submerge the unavoidably submerged part (the impeller), which requires the drive shaft to penetrate the vessel. The latter solution concentrates the design challenge in the shaft penetration(s), since the components outside the pressure boundary become reasonably standard technology.

\section{Technology Status}

There is no real "circulator" technology status to report on. The knowledge to design and construct circulators is not trivial, but it resides in many vendors, and it is supported by proven CFD and FEA tools. The limiting technology for NGNP is in the components.

- The impeller challenge is mostly in its material (required strength at temperature) and manufacturing (primarily if the material temperature needs to be reduced with internal cooling to retain the material strength, but blade shapes are typically complex). In turbine design the state of the art with cooling gas injection, single crystal blades and stabilized surface layers allows blades to operate in gas that is very close to the material melting point. However, with a fan/compressor blade (negative pressure gradients at the surface) and turbulent inlets, with potential decarburization and embrittlement of the surface material, temperatures above $500^{\circ} \mathrm{C}$ may be challenging / limiting. Note that material fatigue-level strength at material temperature is the limiting factor, not the gas temperature itself. Several factors in the design must be optimized and can be altered to determine a successful aerodynamic/stress design combination.

- Bearings, if submerged in helium - For bearings operating in air (i.e., helium effects and oil contamination are no longer factors), standard technology provides a solution. In terms of in-helium options the following may be considered:

- Gas Bearings: Mature - Limited number of stop-starts before refurbishment is required, requires clearances that reduce aerodynamic efficiency, limited pressure and speed operating profile, may require a gas injection support system to support sufficient load bearing characteristics (e.g., a secondary compressor)

- Automatic Magnetic Bearings (AMB): Mature - In theory a zero-wear design with unlimited stop-start cycles, requires clearances that reduce aerodynamic 
efficiency, unlimited operating profile, high load bearing characteristics, but requires coils and instruments in the helium, and numerous vessel penetrations, all subject to potential helium absorption, and electrical short circuits due to graphite dust

- Ceramic Bearings: Probably insufficiently mature in applications in circulators Current status of testing in helium with dust is uncertain, but irrespective of this, they do not claim extensive life expectancy and have high cost. They are sometimes proposed/used as catcher bearings.

- Electrical Penetrations - Glass or ceramic encapsulated conductors. The technology is proven, but as power and motor speed increases it will become more difficult to pass sufficient current into the vessel, while avoiding local heating effects and short circuiting in helium and dust. These penetrations are bulky and need to be kept relatively cold, since they are maintained in position by compression. The limit of this technology is typically well understood, and it is extensively used in the nuclear industry for instrumentation, although the helium adds a new dimension that may require further qualification. (Were used up to $9 \mathrm{MPa}, 100^{\circ} \mathrm{C}$ in helium-dust in the $\mathrm{HTF}$ )

- Shaft Penetrations - In helium the most practical solution is Dry Gas seals (DGS). This technology has proven applications that probably exceed needs in pressure, speed and shaft diameter, but its drawbacks are temperature $\left(\sim 300^{\circ} \mathrm{C}\right.$, local cooling), maintenance (finite life) and it is not a zero-leakage solution, requiring a support system with clean buffer gas, leak recovery and processing, and back-stop gas. They are delicate devices that can be damaged, and therefore need high rotor and bearing stiffness.

- High Speed Motors: Motors are only a challenge if they are internal in the helium. Once outside the motor can be standard, and the use of a gearbox is possible. If inside the vessel they are exposed to higher temperatures, and the direct drive (gears will not do well in helium) requires them to be integrated with the rotor and run at higher speeds. This requires an integrated cooling design, and the problems with degassing in helium become pronounced as the physical size of the motor increases. A limiting factor is cooling the conductors, to prevent degrading the insulation in the presence of helium and conductive dust.

The challenge is not in a specific component's technology, but to provide an integrated design that satisfies the design criteria of robustness, no or low maintenance, and high efficiency.

\section{Procurement Lead Time}

The primary reason for circulators being classified as Category B is Lead Time. The first step would be to evaluate the possible configurations with a confirmed operating requirement. Once the concept is decided, the designer would probably opt for risk mitigation tests that could be 
used as design input, such as material tests of the impeller material, penetrations and motor/AMB coils in high temperature helium, to assess the impact of degassing, embrittlement, and dust. Since these tests are of an accelerated aging type, they do need time. The assumption is that after 18 months the tests are not complete, but the designer would have sufficient confidence to decide on a concept to pursue. It typically takes 18 months to design one of these complex circulators, because it requires iterative optimization between the aerodynamics (impeller), the thermal design, rotor stiffness, bearings and penetrations (and the vessel ultimately). A prototype is then constructed (12 months) and extensively tested (24 months). During the latter part of the test phase the design is improved, and a new 'final' non-prototype circulator is built (add 12 months). Before this circulator can be used, the owner would need to be convinced of its reliability and robustness (24 months of testing). While this circulator is qualified the actual circulator for plant use is built, because it is likely that the qualification blower, intentionally taken into surge, etc., would not be used in the plant. Adding everything up, it suggests a 9 year development and procurement process. If tests go well, it can be compressed. Steps can be skipped, but it escalates the investment risk as well. If a concept fails in testing, the process can be substantially longer while the alternate concept is developed. It is this "Integration and Qualification" risk that makes the circulators a NGNP risk item.

\section{Issues for NGNP}

The greatest 'issue' for NGNP is that it needs a highly reliable circulator, and the complexity in component integration is high. The circulators are proposed as Category B due to their long design and qualification lead time.

\subsubsection{Status}

\section{Vendors}

There are several vendors with the capability to support the development. On the HTGR both Howden UK (submerged AMB design, taken to 100kW operating system) and MHI (Dry Gas Seal design) have participated. However, the skill also resides in other companies. Note that the 'circulator vendors' typically manage the design in terms of the aerodynamics and performance, but that they use established sub vendors for specialist components such as penetrations (Schott, IST Conax), DGS (John Crane, et al), AMBs (Waukesha, et al), electric motors, and ASME III vessels. The IP used are therefore distributed. It therefore makes sense to identify technology partners early, and establish good communication channels. This only really works if the subvendor is not in a competitive relationship with other vendors when dealing with the system integrator.

Capacity 
Capacity is unlikely to be a restrictive characteristic for supply. The circulator manufacturing facilities would be the same as for the great volume of fans, compressors and blowers currently being made.

\section{Expansion}

There is not an expectation that the design would migrate to a point where either the manufacturing capacity or the exotic nature of materials selected would require manufacturing expansion.

\section{QA / QC / NQA-1 Program}

The only feature of the circulators that one would expect to be subject to a nuclear safety quality program would be the function of containment. The vessel and electrical penetrations would be supplied by an appropriate ASME III vendor, and these items are used in nuclear facilities currently. All other QC programs on components will be driven by the requirement for reliability, in order to support plant productivity.

\subsubsection{Path Forward for NGNP}

It is important for the design and development of the circulator that the requirement objectives for the circulators be established, so that the appropriate material and component testing on a bench scale can be initiated as soon as possible. The results from these tests would support a decision on the most appropriate circulator concept. This will in turn support the choice of the most appropriate vendor-partners in the development, because the design, especially if it leans towards the $>8 \mathrm{MW},>400^{\circ} \mathrm{C}$ range, will be challenging.

\subsubsection{Conclusions and Recommendations for NGNP Project}

Recommendations on concept will not be possible until an operating regime for the NGNP main circulator is defined. That should be the first step.

The key decision on the speed and size of the impeller will be driven by impeller materials at the operating temperature and in helium. Step 2 is to start materials characteristic qualification in the defined environment. It is the one component that MUST be in helium.

The next step is to decide between a submerged motor or not. For the specific design conditions the relative merits of Dry Gas Seals need to be evaluated against the challenges of the submerged motor (electrical insulation and cooling of the coils in the size range of the anticipated motor) and electrical penetrations. The AMB coils are just a subset of the motor and penetration challenges. 
Material aging benchmark testing must start as soon as possible, because the answers they provide are key in development risk mitigation. The limitations and complexity defined by these results are key to effective decision making.

The above comments are based on HTF experience, which is on the reference list. Further discussion of Westinghouse's experiences with helium circulators is included in Appendix C.

\subsection{Fuel Assemblies and Fuel Particles}

Fuel assemblies and fuel particles correspond to Items $10 \mathrm{a}$ and $10 \mathrm{~b}$ in the matrix.

It is important to note that fuel assemblies (i.e., pebbles or prismatic blocks) and fuel particles (plus compacts) can be considered as separate infrastructure needs. Specifically, fuel particles may be fabricated by one vendor, while the finished pebbles (or compacts and/or fuel blocks) could be fabricated by different vendor(s).

\subsubsection{Description}

Fuel assemblies (pebbles or prismatic fuel blocks) and fuel particles (triso coated UO2 or UCO particles) are well known and are not described here.

\subsubsection{Status}

The status today of fuel particle fabrication capability is well recognized, and is not elaborated in this report. No vendor exists which has the capability to manufacture a full core loading for NGNP on a timely schedule, plus the ability to provide reloads.

NFI (Japan) most recently provided the fuel for the small HTTR reactor, and is considering providing limited reload fuel, in conjunction with JAERI.

B\&W / NFS (US) has limited quantity ability to manufacture fuel particles, and has fabricated particles currently in the AGR (Advanced Gas Reactor) fuel qualification program at Idaho. $\mathrm{B} \& \mathrm{~W}$ does not have the capability to produce finished pebbles, compacts or to fabricate fuel blocks.

China most recently fabricated the pebble loading for their small HTR-10, but is not considered to be a viable vendor for NGNP at this time.

The PBMR Company, which planned to build a commercial scale fuel facility, is not viable at this time. 


\subsubsection{Path Forward for NGNP}

The highest priority need for NGNP is to address the lack of qualified fuel vendor(s).

\subsubsection{Conclusions and Recommendations for NGNP Project}

The highest priority need for NGNP is to address the lack of qualified fuel vendor(s).

\subsection{High Temperature Helium Valves}

High temperature helium valves correspond to Item 12 in the matrix.

\subsubsection{Description}

The typical valve types and numbers required for a Brayton Cycle (direct helium cycle) plant are described below, as for a $400 \mathrm{MWt}$ PBMR.

The following table provides a summary of the valve types, typical numbers and procurement lead times for helium valves (compressed air and cooling water valves are excluded).

Table 2. Helium Valves for the 400 MWt PBMR

\begin{tabular}{|l|c|c|c|}
\hline \multicolumn{1}{|c|}{ Valve Type } & $\begin{array}{c}\text { Total, 3 inch } \\
\text { and larger }\end{array}$ & $\begin{array}{c}\text { Total, 2.5 inch } \\
\text { and smaller }\end{array}$ & Lead Times \\
\hline $\begin{array}{l}\text { Control Valves; Modulating and On/Off; MOV and } \\
\text { AOV; Globe Type; Conventional Operational Speeds }\end{array}$ & 62 & & $12-15$ months \\
\cline { 2 - 4 } $\begin{array}{l}\text { Control Valves; Modulating and On/Off; MOV; Butterfly } \\
\text { Type; Conventional Operational Speeds }\end{array}$ & 9 & 226 & $9-12$ months \\
\hline Control Valves; On/Off; Globe Type; Fast-acting & 13 & - & $9-12$ months \\
\hline Hand Valves (Maintenance Valves); Globe Type & 29 & - & $24-30$ months \\
\hline $\begin{array}{l}\text { Check Valves (One-way Valves); Globe and Swing-disk } \\
\text { Type }\end{array}$ & 12 & 52 & $8-10$ months \\
\hline Instrument Root Valves & & & $8-10$ months \\
\hline Safety Valves (Safety Relief Valves) & - & $2000-3000$ & $4-6$ months \\
\hline Burst Disks (Rupture Disks) & 5 & 141 & $9-12$ months \\
\hline Total & 14 & 12 & $4-6$ months \\
\hline
\end{tabular}

*Excluding Root Valves

The lead times for most of the valve types presented above were confirmed during the construction of the Helium Test Facility (HTF) at Pelindaba, South Africa. Although no valves 
were required to be $\mathrm{N}$-stamped, preference was given to suppliers that were maintaining their $\mathrm{N}$ certifications, should construction of the PBMR have gone ahead.

Table 3. Helium Valves for the Helium Test Facility

\begin{tabular}{|l|c|c|c|}
\hline \multicolumn{1}{|c|}{ Valve Type } & $\begin{array}{c}\text { Total, 3 inch } \\
\text { and larger }\end{array}$ & $\begin{array}{c}\text { Total, 2.5 inch } \\
\text { and smaller }\end{array}$ & Lead Times \\
\hline $\begin{array}{l}\text { Control Valves; Modulating and On/Off; MOV and } \\
\text { AOV; Globe Type; Conventional Operational Speeds }\end{array}$ & 15 & & $9-12$ months \\
\cline { 2 - 4 } & & 53 & $9-12$ months \\
\hline Hand Valves (Maintenance Valves); Globe Type & 7 & 115 & $8-10$ months \\
\hline $\begin{array}{l}\text { Check Valves (One-way Valves); Globe and Swing-disk } \\
\text { Type }\end{array}$ & 3 & 8 & $8-10$ months \\
\hline Instrument Root Valves & - & 240 & $4-6$ months \\
\hline Safety Valves (Safety Relief Valves) & 8 & 20 & $9-12$ months \\
\hline Burst Disks (Rupture Disks) & 11 & - & $4-6$ months \\
\hline Total & 44 & $196^{*}$ & \\
\hline
\end{tabular}

*Excluding Root Valves

Over and above the helium gas valves, extensive work was carried out in South Africa on the valves or process elements required for a re-circulating fuel handling system for a spherical fuel design - such as the PBMR. The following elements were developed as part of the Fuel Handling System. Each of the valve inserts are installed in a common body (valve block), primarily for shielding purposes.

In total 12 valve blocks housing between 3 and 15 inserts were required. The following process elements make up a typical Fuel Handling System.

Table 4. Fuel Handling Valves (Process Elements) with Fuel Spheres Passing Through

\begin{tabular}{|l|l|l|}
\hline Item & Description & Qty in Plant \\
\hline 1 & Indexers & 17 \\
\hline 2 & Flow Restricting Indexers & 10 \\
\hline 3 & Diverters & 14 \\
\hline
\end{tabular}

The following Block Valve elements were developed as part of the Fuel Handling System.

Table 5. Fuel Handling Helium Valves Imbedded in Valve Blocks

\begin{tabular}{|l|l|l|}
\hline Item & Description & Qty in Plant \\
\hline 1 & Flow Isolation Valves & 28 \\
\hline 2 & Three Way Valves & 9 \\
\hline 3 & Control Valves & 10 \\
\hline 4 & $\begin{array}{l}\text { Pressure Isolation Valves (Double } \\
\text { Seat Isolation Valve) }\end{array}$ & 30 \\
\hline
\end{tabular}


All of the above elements typically used the same valve stem (shaft penetration design) and radiation shielding shaft design (one of each used for each of the block valve inserts.)

The lead time for the production of the valve blocks and inserts are less than 1 year, but the designs may likely require qualification. This was done in part for the PBMR, but different operating pressures and temperatures may require a re-qualification period of 3 to 4 years. Also, no fabricator was found that has $\mathrm{N}$-certification.

The technology status for all of the above is largely driven by operating temperatures. The vast majority of the valves were designed for operating temperatures not higher than $330^{\circ} \mathrm{C}$, for which no qualification problems are foreseen at all. The fuel handling valves still had to undergo accelerated life time qualification however. The highest required temperatures for gas valves in the $\mathrm{HTF}$ were $610^{\circ} \mathrm{C}$, once again without any qualification problems. The PBMR design potentially had a small number of valves that would exceed $610{ }^{\circ} \mathrm{C}$, and such valves may be required for other high temperature gas reactor designs. The largest challenge for operating temperatures exceeding $610^{\circ} \mathrm{C}$ is the creep rupture life, but current work by ASME LLC seeks to establish design rules for austenitic stainless steels (up to and exceeding $650^{\circ} \mathrm{C}$ ) and Alloy $800 \mathrm{H}$. In terms of the latter, the objective is to provide allowable stress values for as high as $850^{\circ} \mathrm{C}$ and $500,000 \mathrm{hr}$, with short term abnormal temperature excursions even above this (bounded by anything between 100 to 10,000 hours). Even with these rules completely developed and put into place, for relatively high operating pressures, temperatures in excess of $650^{\circ} \mathrm{C} / 700^{\circ} \mathrm{C}$ will likely result in hot pipe designs, whereby a double wall is employed with cooling flow in the outer annulus to protect the main pressure boundary against high temperatures. The inner passage can then be exposed to the high temperatures. Special valve designs only exist as concepts today, and will have to be developed and tested in conjunction with recognized hot pipe designers such as Technip. This means that the high temperature material limitations may well push these designs to Category $\mathrm{C}$, with an unknown development time period - most probably in excess of 5 years.

Other potential technology issues are leak tightness and valve stem stiction. Both of these were addressed in the HTF and PBMR designs, and may prove adequate for future designs. In terms of leak tightness, there are several vendors that can offer completely sealed designs, i.e., using the process medium itself to provide the actuating means. The existing designs however may not cover all functional requirements, as these designs were previously developed for specific applications.

Valve specifications that were used in the HTF design required valve designs of Category A in terms of readiness for NGNP. High actuation speeds, elevated temperatures (in excess of $610^{\circ} \mathrm{C}$ but not exceeding $650^{\circ} \mathrm{C}$ ) and/or extreme leak tightness will place the designs as Category B in terms of NGNP readiness. 


\subsubsection{Status}

Valve vendors with specific helium experience are not common-place, but this is not necessarily a reason for disqualification. It will largely depend on the required specification for leak tightness and control characteristics, as well as operating temperatures.

The following vendors have supplied valves to the HTF, and operating experience therefore exists.

Table 6. Vendors Used in the HTF Construction

\begin{tabular}{|c|c|c|c|}
\hline Vendor & Critical Items/ General Comments & $\begin{array}{c}\text { NQA-1 } \\
\text { Program }\end{array}$ & $\begin{array}{l}\text { N/NV/NPT } \\
\text { Certification }\end{array}$ \\
\hline Broady Flow Control & $\begin{array}{l}\text { Safety Valves with ceramic disks to prevent self- } \\
\text { welding in dry helium, not a proven nuclear track } \\
\text { record yet. } \\
\text { Several other suppliers also exist for safety } \\
\text { valves, some of which maintain NV Certification }\end{array}$ & & No \\
\hline Segault S.A. & $\begin{array}{l}\text { Specialist Valve Developer, well-suited for new } \\
\text { designs, nuclear qualified supplier } \\
\text { Capacity limited }\end{array}$ & & No \\
\hline $\begin{array}{l}\text { Target Rock (a Curtiss } \\
\text { Wright company) }\end{array}$ & $\begin{array}{l}\text { Completely sealed design, nuclear qualified } \\
\text { Capacity uncertain }\end{array}$ & Yes & Yes \\
\hline Velan S.A.S & $\begin{array}{l}\text { Proven nuclear track record, focus on control } \\
\text { valves. Can provide 1-E actuators } \\
\text { Decent capacity, but availability varies } \\
\text { significantly due to other nuclear work }\end{array}$ & Yes & Yes \\
\hline Velan Inc. & $\begin{array}{l}\text { Hand valves (maintenance valves), supplies own } \\
\text { forgings } \\
\text { Large capacity, but availability varies with } \\
\text { world-wide nuclear and fossil power plant } \\
\text { construction }\end{array}$ & & \\
\hline
\end{tabular}

In terms of the fuel handling valves and valve blocks, supply of materials required for these components vary from readily available high tensile steel to steel as required under the ASME codes for pressure boundary components.

Specialist polymers are also used in the components - the most significant being Vespel - a polyamide supplied by Du Pont. This material is available and requires only sufficient supply time. 
Special helium bearings (extreme environment bearings) are used in the shaft penetrations. These were supplied by Cerobear of France, and require only sufficient manufacturing time ( $\sim 6$ months) as a supply consideration. These bearings were however never fully tested in a pure helium environment. A bearing test program should be considered as a separate development effort (2 years).

The valve inserts can be manufactured by general machine shops requiring some tooling and manufacturing process design, but no special manufacturing technology. The shaft penetrations are typically ASME III NC components and the quality assurance required for these types of components require special quality consideration and ASME NPT certified manufacturers.

Valve blocks are ASME III NB/NC components. As they weigh up to 12 tons, they require machine shops that are ASME NPT stamp certified manufacturers.

\subsubsection{Path Forward for NGNP}

The path forward will depend greatly on the design choices that will be made for NGNP. The following aspects will influence the choice of valve designs, as well as the infrastructure readiness:

1. Operating temperatures - see discussion above

2. Actuation times - a direct cycle design requires fast actuation for turbine protection

3. Control characteristics - fine control movement may be challenging with valve stem seal designs that can also provide the necessary leak tightness

4. External leak tightness - development of long-life bellows may be required, if needed for high-cycle valves

5. Isolation philosophies - safety related isolation may require some additional qualification that will impact on delivery times, but not necessarily any worse than Category B

6. Fuel handling concept will have an impact, as discussed above. The re-circulating fuel concept is not an un-tested technology, but will require refinement.

7. Self-welding - several hard facing materials have been developed for contact surfaces in extremely dry environments

Timely engagement with potential valve vendors must be made to ensure that technology issues are adequately resolved. 


\subsubsection{Conclusions and Recommendations for NGNP Project}

Valve operating temperatures will be a deciding factor. High temperature gas reactor designs so far have elected to reduce the necessity of having valves at reactor outlet temperatures. Careful design selection may remove the high temperature challenges on valves specifically.

Apart from the temperature, none of the other considerations will result in a Category $\mathrm{C}$ readiness level. Several of these may well result in Category B, depending on design choices and licensing requirements.

The general response from vendors is that the helium-nuclear portion of their business is so small, and the general QA-QC processes in order to compete in a competitive industry so high, that they would install processes and accreditations that made business sense.

There are no specific references, since this write-up is based on the experiences of the HTF/PBMR Valve team.

\subsection{Nuclear QA/QC Programs}

Nuclear QA/QC programs correspond to Item 13 in the matrix.

\subsubsection{Description}

Quality Assurance (QA) comprises all the planned and systematic actions necessary to provide adequate confidence that a system, structure, or component will perform satisfactorily in service. Quality Control (QC) is included as part of a QA program. Nuclear QA regulations for commercial nuclear power in the United States include 10 CFR 50, Appendix B for Federal Quality program requirements, 10 CFR50, Part 21 for reporting defects issues, 10 CFR 50.55 for codes and standards, and Regulatory Guide 1.28 for the NRC adoption of ANSI/ASME standards. ASME Section III covers the nuclear boilers and pressure vessels, ASME NQA-1 covers the nuclear QA program requirements for Nuclear Facilities, and ISO-9001-2008 is the international standard for conventional industry QA programs.

Generally, the concern about nuclear QA/QC is that because little new nuclear construction has taken place in the United States for decades that the companies that had produced nuclear components in the past are no longer in business or have not maintained their nuclear QA/QC programs and certifications. As noted in the MPR report (Reference 13), QA/QC problems 
caused major difficulties in earlier nuclear plant construction projects and thus it is imperative for the appropriate $\mathrm{QA} / \mathrm{QC}$ programs to be in place and properly implemented for the design, fabrication, construction, and inspection of new nuclear plants. However, according to the MPR report there is not a shortfall in international nuclear certified fabricators or metal manufacturers for expected future domestic light water reactor demand.

The lead time for obtaining an ASME N-Stamp and compliance with ASME NQA-1 standards depends largely on the current $\mathrm{QA} / \mathrm{QC}$ programs in place; however, for a company that formerly produced certified nuclear components, the lead time is expected to be about a year. Because the QA/QC programs must be in place for the design and fabrication phases of the project, the lead time relative to the commercial operation date is seven to eight years.

For NGNP the typical QA/QC issues expected will require focusing on the certification of components that are specific to HTGRs which would not have been addressed as a result of the near term construction of light water reactors. Vendors that produce these HTGR-specific components may not have ever had any experience with nuclear QA/QC and thus conforming to the appropriate standards could be challenging. HTGR-specific items identified for nuclear QA/QC include: circulators, graphite, helium valves, fuel handling system, reserve shutdown system (RSS), RSS valve actuator, small absorber spheres, reactivity control system, control rod system stepper motor, and control rod system ceramic bearings. As experienced by the PBMR company, suppliers had very good experience using ISO 9001 as their QA program for very highly complex and safety level component supply, such as for NASA, but had no exposure to the specific and prescriptive QA requirements of ASME or NQA-1.

\subsubsection{Status}

Circulator vendors include Howden UK for the submerged AMB design and MHI for the dry gas seal design. The containment / casing is the only feature of the circulators that one would expect to be subject to a nuclear QA/QC program. Circulator vendors typically contract with another supplier for the containment. Similarly, the vessel and electrical penetrations are also typically supplied by other ASME III vendors. Howden UK has relationships with suppliers such as Schott AG in Germany for the supply of electrical penetrations that have nuclear QA/QC programs.

No graphite vendors currently have an ASME or nuclear compliant QA/QC program. The deployment and accreditation of graphite suppliers to meet the requirements in ASME Section III, Sub-section NCA-4000 (a tailored version of ASME NQA-1) still requires some development work. In order to supply the graphite core assembly for the NGNP, the graphite supplier will be required to have a G-Certificate (which certifies that the supplier has an appropriate nuclear graphite $\mathrm{QA} / \mathrm{QC}$ program in place). The timeframe for issuing a G- 
Certificate is approximately two years from now, contingent on the ASME code including the requirements for Graphite Core Components being published by summer 2011, an ASME accreditation program for Graphite Core Components being in place by a year after that, and at least one graphite supplier applying for a G-Certificate. If the graphite needs to be supplied under the requirements of an ASME QA Program, then it shall most likely need to comply to NCA 3800 for material organization. In the event that the Graphite design, fabrication and supply organization need to comply, NCA 4000 shall have to be used, typically for the conventional N stamp holder.

Multiple components that make up the helium valves require nuclear QA/QC programs. The shaft penetrations are typically ASME III NC components and require nuclear QA/QC programs and ASME NPT certified manufacturers. Valve blocks are ASME III NB/NC components. They can weigh up to 12 tons and require Machine Shops with ASME NPT stamp certified manufacturers. Valve vendors that supplied valves to the Helium Test Facility (HTF) and have an NQA-1 program and N-certification include Target Rock (a Curtiss Wright company) and Velan. Other manufacturers of nuclear grade valves that have ASME N-stamps include: Control Components, Flowserve, Crane Nuclear, and Fisher Controls.

The timeframe for design qualification would likely be less than one year; however, if different operating pressures and temperatures from the PBMR design are required, then a requalification period of three to four years may be required. The general response from vendors is that the helium-nuclear portion of their business is so small, and the general QA-QC processes in order to compete in a competitive industry so high, that they would install processes and accreditations that made business sense.

\subsubsection{Path Forward for NGNP}

In order to ensure that the NGNP plant can be built without schedule delays due to rework, all of the primary organizations, including the NRC, utility, nuclear system vendors, component suppliers, material suppliers, and EPC contractors, must ensure that nuclear QA/QC programs are properly in place for all phases of the project, starting with design and fabrication. For the NGNP project particular focus is required for HTGR-specific vendors that do not have previous nuclear QA/QC experience. Specifically, a nuclear graphite QA/QC code and accreditation program needs to be developed such that nuclear graphite QA/QC programs can be certified. The NGNP project should coordinate with graphite vendors and ASME / National Board to ensure that such programs will be in place in time for NGNP deployment.

\subsubsection{Conclusions and Recommendations for NGNP Project}


Overall the nuclear QA/QC programs are developed and available for use on an NGNP, even the items that are particular to HTGR technology and NGNP. The major exception is graphite, which still requires some code and program development on the part of ASME and the vendors.

\subsection{Graphite Core Components and Raw Material}

Graphite core components and raw material correspond to Items 27 and 19 in the matrix.

\subsubsection{Description}

This assessment is based on the requirements for construction of a Pebble Bed option. The assessment is in two main parts:

- Specifically, the requirements for the graphite of the Graphite Core Assembly, and

- the required graphite raw materials to be used for the manufacture of Pebble Bed fuel elements.

We exclude development of enhancing technology, considering only the requirements needed to deploy a reactor system to the same standards as employed historically by other gas cooled reactor programs.

The following main items and activities were considered:

Graphite Core Components (GCC)

- Engineering and Qualification

- Feedstock

- Fabrication (machining of parts)

- Installation

Fuel Fabrication Raw Materials (FRM)

- Natural graphite

- Electro graphite

For this assessment it was necessary to consider the infrastructure needed to deploy the reactor system. This included an assessment of the infrastructure needed to complete all the activities.

Our assessments of the needs were as follows: 
- GCC Engineering and Qualification. Resources (companies or individuals) that can perform the required engineering and qualification effort.

- GCC Material Manufacture. Manufacture of the material to the required standards, both technical and administrative (quality).

- GCC Fabrication (part machining). Manufacture of the GCC to the required standards, both technical and administrative (quality).

- GCC Installation. Installation of the GCC into the reactor while meeting all the technical and quality requirements.

- FRM Natural Graphite. Source and supply raw material for fuel fabrication.

- FRM Electro Graphite. Source and supply raw material for fuel fabrication.

Procurement Lead Time - Based on PBMR experience we identified the following as typical lead times:

- GCC Engineering and Qualification. Approximately 24 months duration. (Some long duration qualification activities, such as the irradiation test program, to run in parallel with manufacture.)

- GCC Material Manufacture. 12 months lead followed by 24 months manufacture duration. Lead can overlap with engineering.

- GCC Fabrication (Part machining). 12 months duration.

- GCC Installation. 3 - 4 months duration.

- FRM Natural Graphite. Estimated 6 months lead time. 12 months duration.

- FRM Electro Graphite. Estimated 6 months lead time. 12 months duration.

The major issue for NGNP is the introduction of the ASME Section III, Division 5 Code for the construction of Graphite Core Components. This integrates the quality management requirements for the graphite manufacturers of core components with the quality requirements required by 10CFR50 Appendix B. This is achieved by requiring quality programs at the suppliers that conform to requirements equivalent to NCA-4000 which are a tailored version of ASME NQA-1.

The deployment and accreditation of suppliers to meet these requirements will take time. Our estimate is that the duration will be as follows: 
- June 2011, ASME code that includes requirements for Graphite Core Components is published.

- June 2012, ASME accreditation program is in place for GCC. This assumes that at least one supplier has applied for a G-Certificate.

- December 2012, first G-Certificate is issued. Assuming successful survey.

A party holding a G-certificate will be authorized by the society to supply the Graphite Core Assembly for the NGNP. This is a time consuming process and it requires a supplier request accreditation. We, therefore, suggest that the NGNP program take action to ensure that at least one supplier requests accreditation. This could be accomplished by funding the first application. From the program's perspective it does not matter which graphite manufacturer is the first to get accredited. The program could make use of a competitive tender between the possible suppliers, perhaps with an element of cost sharing, to determine which supplier to support.

\subsubsection{Status}

There are at least three vendors with both the capacity and capability to supply graphite for the NGNP. Note that our assessment on capability is based on the typical designer's material property requirements as listed in Table 7 , not the minimum material properties required by the standard.

In terms of our assessment we focused on two vendors who supplied to the PBMR or HTR-PM programs. This does not mean that other suppliers would not qualify.

- We considered SGL Carbon and Toyo-Tanso as potential suppliers.

- SGL Carbon (manufacturing graphite feedstock in its Chedde plant and machining the parts in the Meitingen plant). SGL has demonstrated capability for the PBMR program. While not all the facilities dedicated to the program are available as some have been decommissioned or repurposed after the PBMR program was terminated, we anticipate that SGL would be able to re-commission these facilities should the need arise.

- Toyo-Tanso (manufacturing material in Marugame and machining it in Shanghai). Toyo-Tanso has demonstrated the capability and capacity to manufacture GCC for the Chinese HTR-PM program.

- No expansion of supply capacity is required for NGNP in the immediate future.

- In terms of the requirement to manufacture a single plant the manufacturing capacity is not an issue. A typical graphite plant producing 
specialty graphite can manufacture between 12,000-20,000 tonnes of graphite per year (Electrode graphite plants produce higher volumes). A single reactor will require less than 2,000 tonnes. Even considering the demand for multiple reactors in a year material manufacture should not be a bottleneck.

- Machining of the GCC may be an issue. Machining is, however, easier to scale than the manufacture of graphite feedstock. The capital expenditure necessary for a single machine (which would increase throughput) is much less than the capital expenditure required to expand the production capability of a graphite plant. It is our assessment that there is sufficient capacity to manufacture the GCC for the NGNP, and that the capacity can be increased, as required, under commercial terms while manufacturing additional reactors for the fleet.

- For GCC no graphite vendor has the required code accredited QA program. This program has been defined but no accreditation requirements are in place at present. Effort should be focused to accredit the suppliers. This will result in a fully qualified supply chain being established.

- For FRM, we expect that this would be dealt with under the QA program of a fuel manufacturer. It is our assessment that the current programs in place will be sufficient for supply of these materials.

\subsubsection{Path Forward for NGNP}

The NGNP program should ensure that at least one supplier is authorized to supply GCC to the new ASME Code Division 5 requirements.

\subsubsection{Conclusions and Recommendations for NGNP Project}

We identified the priority to ensure that at least one graphite manufacturer is qualified to produce graphite to the new ASME Boiler and Pressure Vessel Code Section III Division 5.

We suggest that the NGNP program act to ensure that at least one graphite manufacturer receives authorization by the ASME to complete this work. 
Table 7. Key Properties - Graphite Feedstock for Core Components

\begin{tabular}{|l|l|l|}
\hline Property & Required by Standard & Designer Preferred \\
\hline Density & $>1.7 \mathrm{~g} / \mathrm{cm}^{3}$ & $\sim 1.8 \mathrm{~g} / \mathrm{cm}^{3}$ \\
\hline $\begin{array}{l}\text { Thermal conductivity at room } \\
\text { temperature }\end{array}$ & $>100 \mathrm{~W} / \mathrm{m} / \mathrm{K}$ & $\sim 145 \mathrm{~W} / \mathrm{m} / \mathrm{K}$ \\
\hline Low absorption cross-section & $(<2 \mathrm{ppm}$ Boron Equivalent $)$ & $\sim 4 \mathrm{mbarn}$ \\
\hline Impurity levels (total ash content) & $<300$ & $<250 \mathrm{ppm}$ \\
\hline $\begin{array}{l}\text { Coefficient of thermal expansion } \\
\left(20^{\circ} \mathrm{C} \text { to } 120^{\circ} \mathrm{C}\right)\end{array}$ & $3.5-5.5 \times 10^{-6} \mathrm{~K}^{-1}$ & $4.0-5.5 \times 10^{-6} \mathrm{~K}^{-1}$ \\
\hline Strength $($ Tensile $)$ & $>15 \mathrm{MPa}$ & $\sim 20 \mathrm{MPa}$ \\
\hline Anisotropy & $1.10-1.15$ & $<1.15$ \\
\hline Billet Sizes & $500 \times 500 \times 1,600 \mathrm{~mm}$ & $500 \times 650 \times 2,000 \mathrm{~mm}$ \\
\hline
\end{tabular}

Sources: References 27 and 28

References for this section include ASTM D7219-08, "Standard Specification for Isotropic and Near Isotropic Nuclear" (Reference 27) and the paper "Graphite and Ceramic Coated Particles for the HTR" from the 34th International Conference on Advanced Ceramics \& Composites (ICACC) (Reference 28).

\subsection{Sensors}

Sensors correspond to Item 21 in the matrix.

\subsubsection{Description}

\section{Background}

This write-up is based on the approach and philosophy followed for the Pebble Bed Modular Reactor (PBMR).

It is understood that a need has been identified to develop new Instrumentation, Controls and Human Machine Interface (ICHMI) systems to maximize the performance of Generation IV Nuclear Power Plants (NPPs). However, the strategy for the PBMR was to use an existing class 1E Nuclear Instrumentation System (NIS). This was done to avoid the possibility of ICHMI equipment becoming a critical path item and to reduce R\&D costs.

\section{Post Accident Measurement System (PAMS)}

Extra qualification of PAMS equipment in the citadel would be required for the High Temperature Reactor (HTR) environment, especially post-event, when 'ambient' temperatures can be very high. 
Effect of pipe breaks on sensors

Design basis pipe breaks would have to be considered for the PAMS. For other instrumentation only "small" breaks would be considered.

\section{Measurements within the Reactor Pressure Vessel (RPV)}

A number of measurements are made within the PBMR Demonstration Power Plant (DPP) RPV. These "in-core" measurements were made by the Core Structures Instrumentation (CSI) system. The functional requirement of the CSI system is limited to the FOAK reactor design and performance validation. In no event was it postulated that the CSI be used for plant control or protection. Instrumentation associated with the CSI is therefore not safety related and is not classified as Class 1E instrumentation.

Types of CSI measurements in the RPV include the following:

- Neutron flux

- Temperature distribution in the graphite reflector

For the first year of operation the following measurements are also monitored in the RPV:

- Mechanical stresses

- Loads and temperatures on the core barrel

- Movement of the core barrel

Again, this full set of measurements was only proposed for the FOAK demonstration plant, and it would support data acquisition for design Verification and Validation (V\&V). The data would also be used for system characterization purposes.

Major challenges include:

- Some of the sensors are not replaceable as they form part of the reactor internal structures.

- High temperatures, pressure and radiation

- Sensor cable penetrations (up to $9.7 \mathrm{MPa}$ ) into the pressure boundary, requiring a (Helium) leak tight seal.

- The installation of the sensors would be complex. Many of the sensors would have to be built in with the Core Structures Ceramics.

- Reliability of sensors. Sensors required for V\&V are required to operate for a design life exceeding 3 full power years. Core Barrel Support Structure measurement channels are 
required to operate for the lifetime of the plant. This would be achieved by providing redundant sensors.

Design considerations include:

- Mineral Insulated (MI) cables connect sensors through penetrations to the point of interface outside the reactor citadel. It is recommended to use $\mathrm{MgO}$ as the isolation material for MI Cables.

- There may not be Source Range (SR) detectors available to withstand extreme temperature conditions. The detectors are, however, not required to do so.

- High operating pressures may be compensated for by selecting a high fill pressure for the detector together with a suitable casing.

- It is recommended to use type $\mathrm{N}$ thermocouples (approximately 250 of them) for monitoring of temperature throughout the core reflector, and across the Core Barrel surface.

- Also consider using fiber optic based strain gauges and temperature measurements

\section{Measurements in harsh conditions}

The temperature change (up to $900^{\circ} \mathrm{C}$ ) influences the process connection (material choices) and the instrument accuracies if operated at the material limits. Standard thermocouples may be used (i.e., Type $\mathrm{K}$ or N); however, the process hookup and probe design should be selected suitable for the temperature/pressure/flow velocity/helium environment and requires special attention. On the cold leg side standard ASME thermowells may be used. Suppliers include: Weed Instruments, Conax, and Auxitrol

Differential Pressure (dP) measurement would be used to derive the flow through the steam generator on the primary loop. Sensing line designs (Hook-ups) require special consideration. The accurate flow measurements required for calorimetrics located in the secondary loop will use standard systems.

Standard NPP pressure transmitters may be used. However a carefully planned philosophy is required for pressure transmitter calibration, ventilation and maintenance. Again, sensing line designs (hook-ups) also require special consideration. For example, flow-restricting orifices could be used in the sensing lines.

Standard Thermo Gamma-Metrics sensors can be used if the NGNP would require only an excore Nuclear Instrumentation System (NIS). This was the approach for the PBMR. It will, however, pose a significant challenge if the NGNP would require an in-core NIS. 


\subsubsection{Path Forward for NGNP}

The following may be considered as the general challenges when considering the requirements imposed on NGNP sensor technology:

- Environmental Qualification of sensors

- The Burn-Up Measurement System for a Pebble Bed concept (see separate description)

- In-core NIS (If the NGNP would require it)

- A moisture measurement which may possibly become Class 1E. If this is the case a new qualification program must be followed, seeing that there are currently no Commercialof-the-shelf (COTS) Class 1E moisture detectors available.

\subsubsection{Conclusions and Recommendations for NGNP Project}

Requirements must be developed and equipment designed, manufactured and qualified.

Environmental qualification in an HTGR environment will be necessary.

\subsection{Burn Up Measurement}

Burn Up Measurement corresponds to Item 31 in the matrix.

\subsubsection{Description}

The Pebble Bed Burn-Up Measurement System (BUMS) measures burn-up, and distinguishes between used and spent fuel. The BUMS can also provide an activity distinguishing function.

The method of BUMS has been subjected to a validation process at the PBMR company. It however is required to take the BUMS through the whole "industrialization" process. The BUMS will have a procurement lead time of more than a year.

\subsubsection{Status}

The only known vendor is Thermo Scientific. Their spectroscopic instrument is designed to measure the burn-up of PBMR fuel spheres by means of spectroscopic evaluation. 


\subsubsection{Path Forward for NGNP}

Continue with the "industrialization" process. Work closely with the identified vendor to meet possible challenges resulting from new or altered requirements imposed on the design by the NGNP.

\subsubsection{Conclusions and Recommendations for NGNP Project}

Further development of the BUMS is required for the NGNP.

\subsection{Core Barrel, Steam Generator and Steam Generator Bundle}

Core Barrel, Steam Generator and Steam Generator Bundle correspond to Items 2, 3 and $3 \mathrm{~b}$ in the matrix.

See also the RPV (Reactor Pressure Vessel) and Large Forgings write-up in Section 4.1.

\subsubsection{Description}

The HTGR / NGNP metallic Core Barrel (CB), Steam Generator (SG) [including a Steam Generator Vessel (SGV) and the SGB] and Steam Generator Bundle (SGB) are included as a specific write-up because, while these component names are the same as for a LWR, and while their functions are the same as for a LWR, the HTGR CB / SG / SGB designs are much different than those of a LWR.

Also, specific to fabrication capabilities for these NGNP components, their dimensions and masses, plus their design differences with respect to comparable LWR components, are significant challenges. These issues are illustrated and described as follows.

Included in this discussion is the NGNP RPV, for completeness.

Figure 1 is representative of the NGNP vessel configuration, showing the RPV, SGV and a cross vessel. 


\section{MHTGR Vessel Concept}

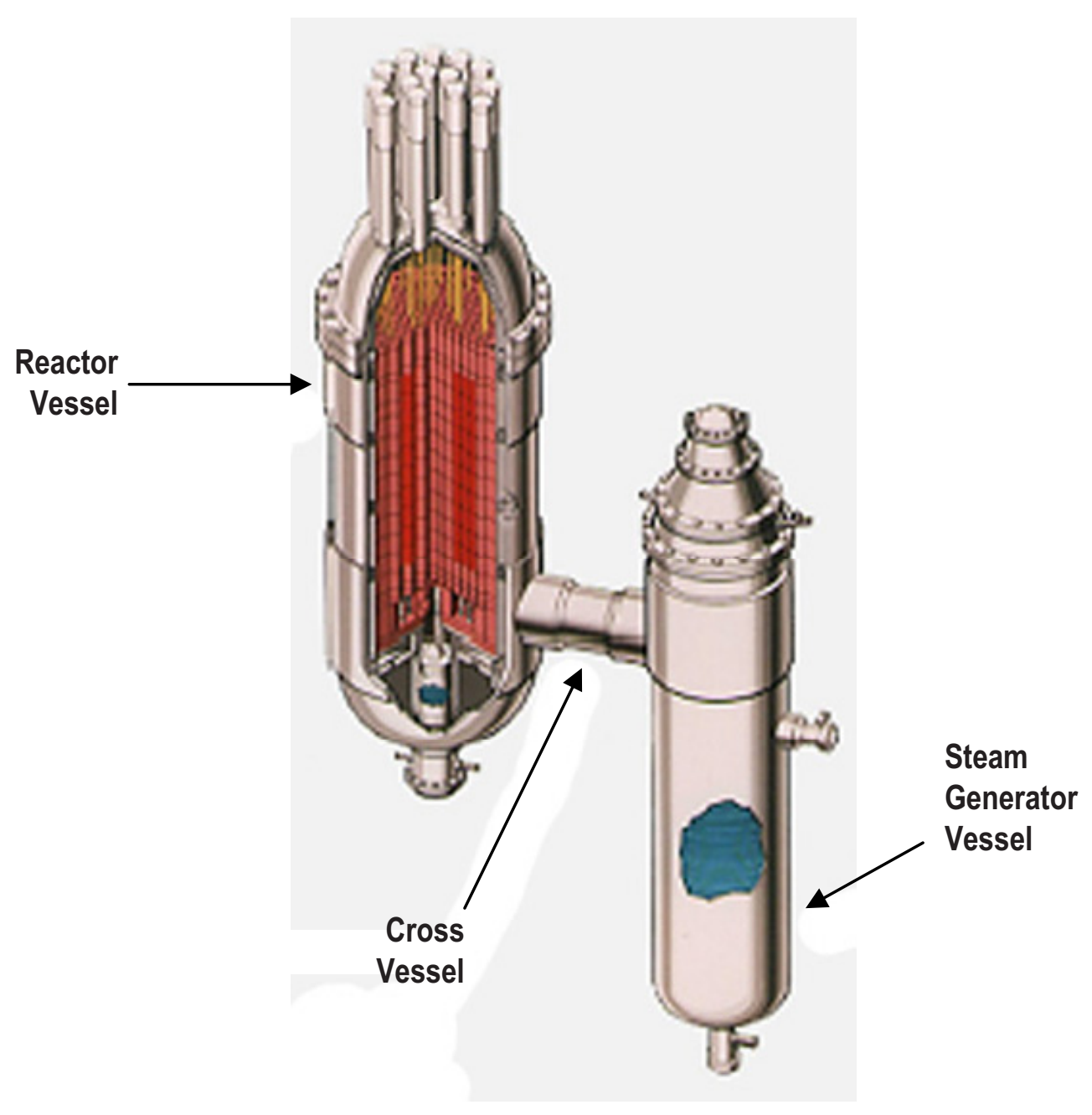

Figure 1. NGNP Vessel Configuration

Figure 2 is a to-scale representative comparison of the main components for MHTGR / NGNP and a large PWR. 


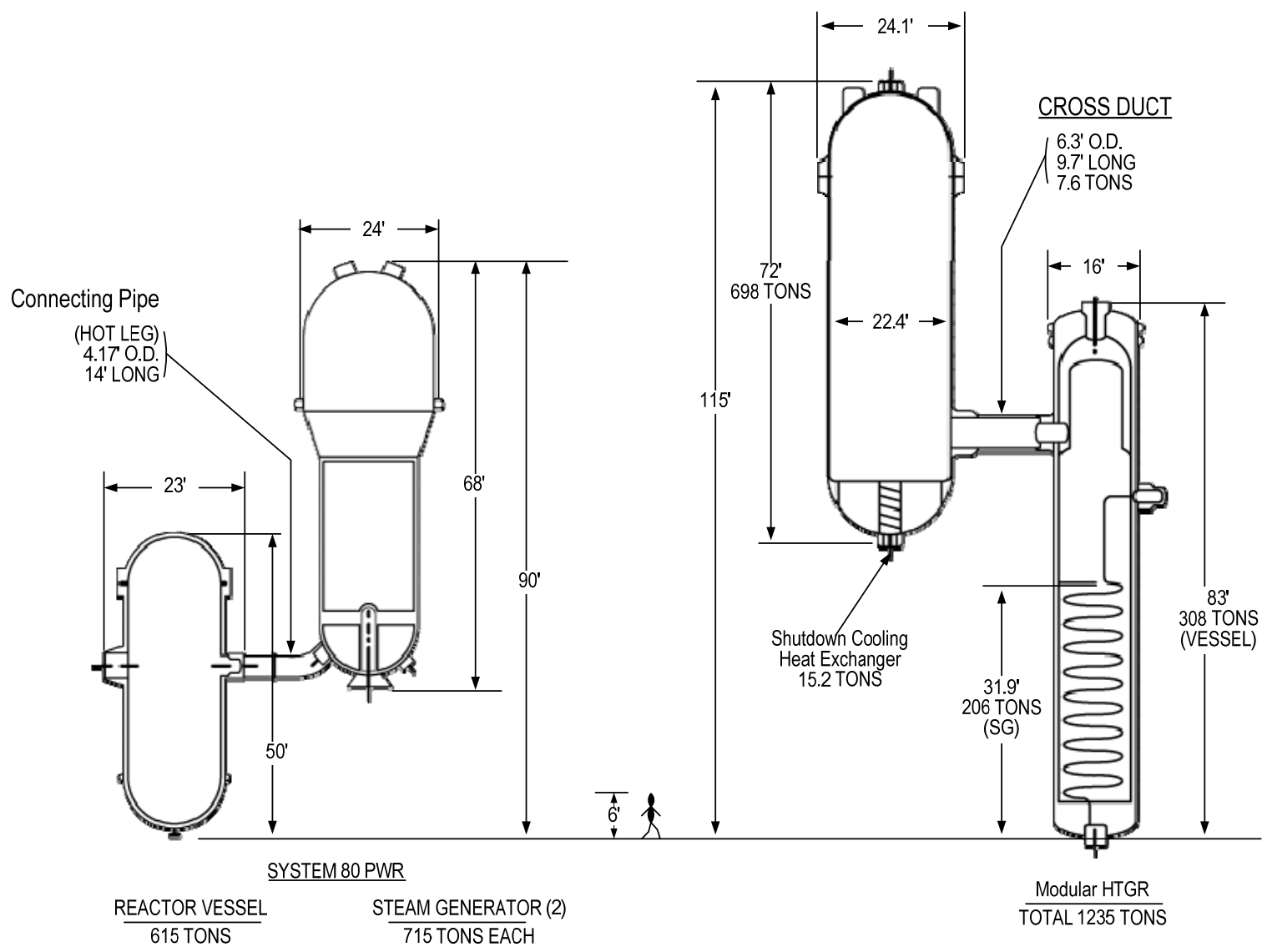

Figure 2. PWR-MHTGR RPV-SG Comparison 
$\underline{\text { NGNP RPV }}$

The FOAK NGNP RPV will be very similar to a large LWR RV, including manufacture from carbon steel SA 533 Type B Class 1 for plates, SA 508 Type 3 Class 1 for forgings and SA 540 Grade B24 Class 3 for bolts.

Per unit power output, HTGR vessels are much larger than LWR vessels (i.e., due to the very low HTGR core power density). The increased size may impact fabricability, transportation to the plant site and availability of forgings. Potential solutions may include partial fabrication of vessels on site and use of welded plate construction (vs. forged rings). 
$\underline{\text { NGNP SG (including SGV and SB) }}$

Figures 3 and 4 illustrate the HTGR SG, SGV and SGB configurations. 


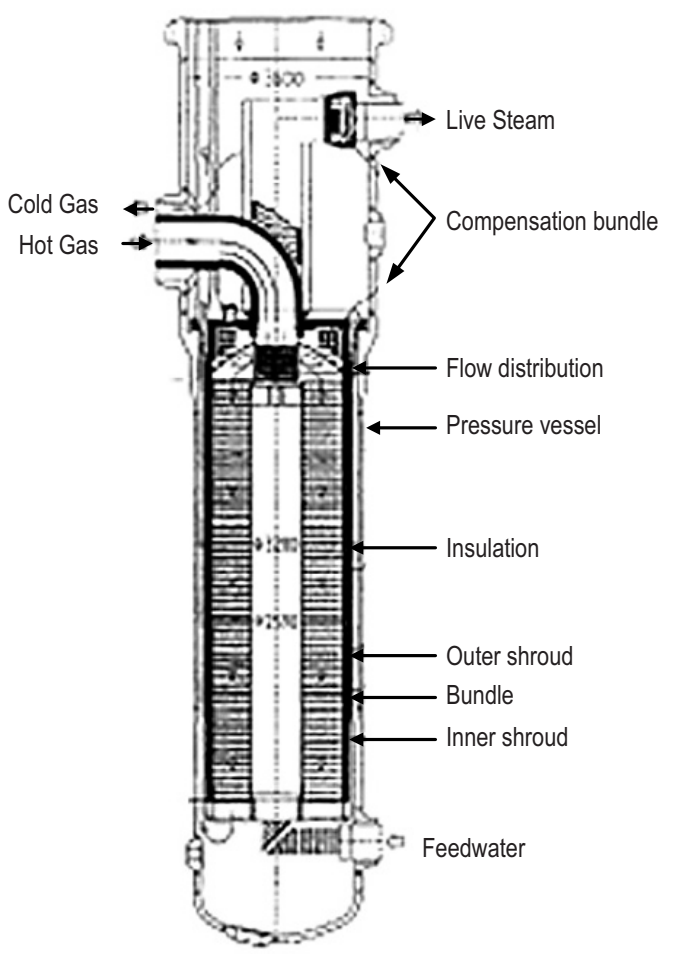

"Uphill" boiling

- Helium flows down

- Water/steam flows up

Reheat $\rightarrow$

4 No reheat

4 Tube sheets

Toroidal headers

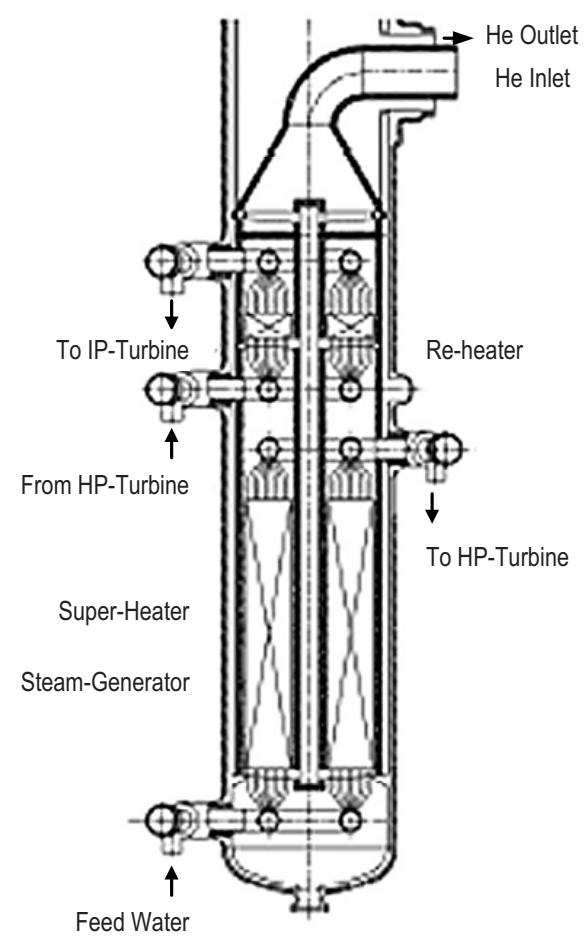

Figure 3. Typical Modular HTGR Steam Generator Configuration 
- Helical coil tube bundle

- Thick wall tubes

- Radial support plates

- Common tubing materials

$-2.25 \mathrm{Cr}-1 \mathrm{Mo}$

$-800 \mathrm{H}$

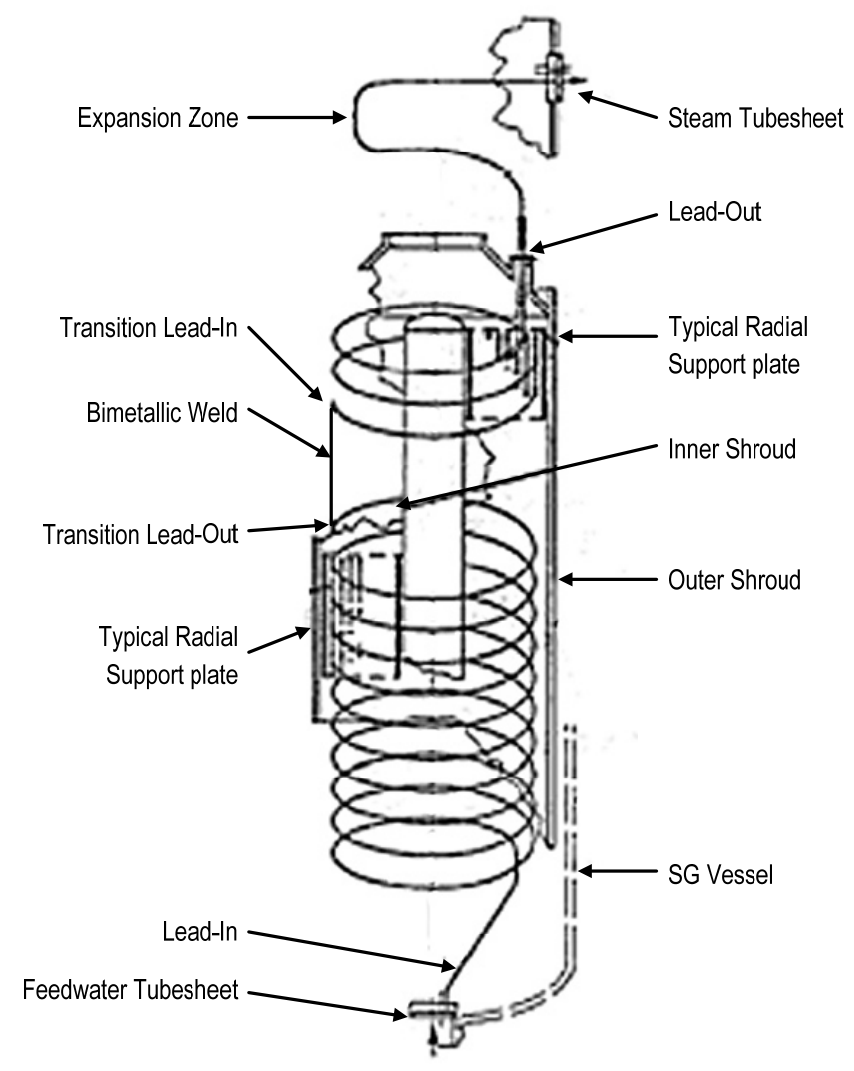

Figure 4. HTGR Steam Generator Helical Coil Bundle 
The HTGR SGV is very comparable to a large LWR. As a result of the reduced heat transfer coefficients for helium-to-steam, on a per unit steam output, HTGR SGs are much larger than for PWRs.

The HTGR helical coil SG Bundle is not comparable to a U-tube PWR bundle. As shown in Figure 4, the preferred, most compact, most economical, most proven design is a helical coil bundle, with thick wall tubes and a radial support structure, using common tubing materials (2.25 Cr-1 Mo and 800H).

\section{$\underline{\text { NGNP Core Barrel }}$}

The NGNP metallic CB is not illustrated here. It is similar in design to a LWR, but is a tall, thin wall cylindrical component, which presents unique fabrication challenges.

\section{$\underline{\text { Comparison of MHTGR / NGNP vs. Large LWR Major Components }}$}

Figure 5 is a to-scale comparison of the MHTGR SGV / MHTGR RV / System 80 PWR SG / Large BWR RV and System 80 PWR RV. 


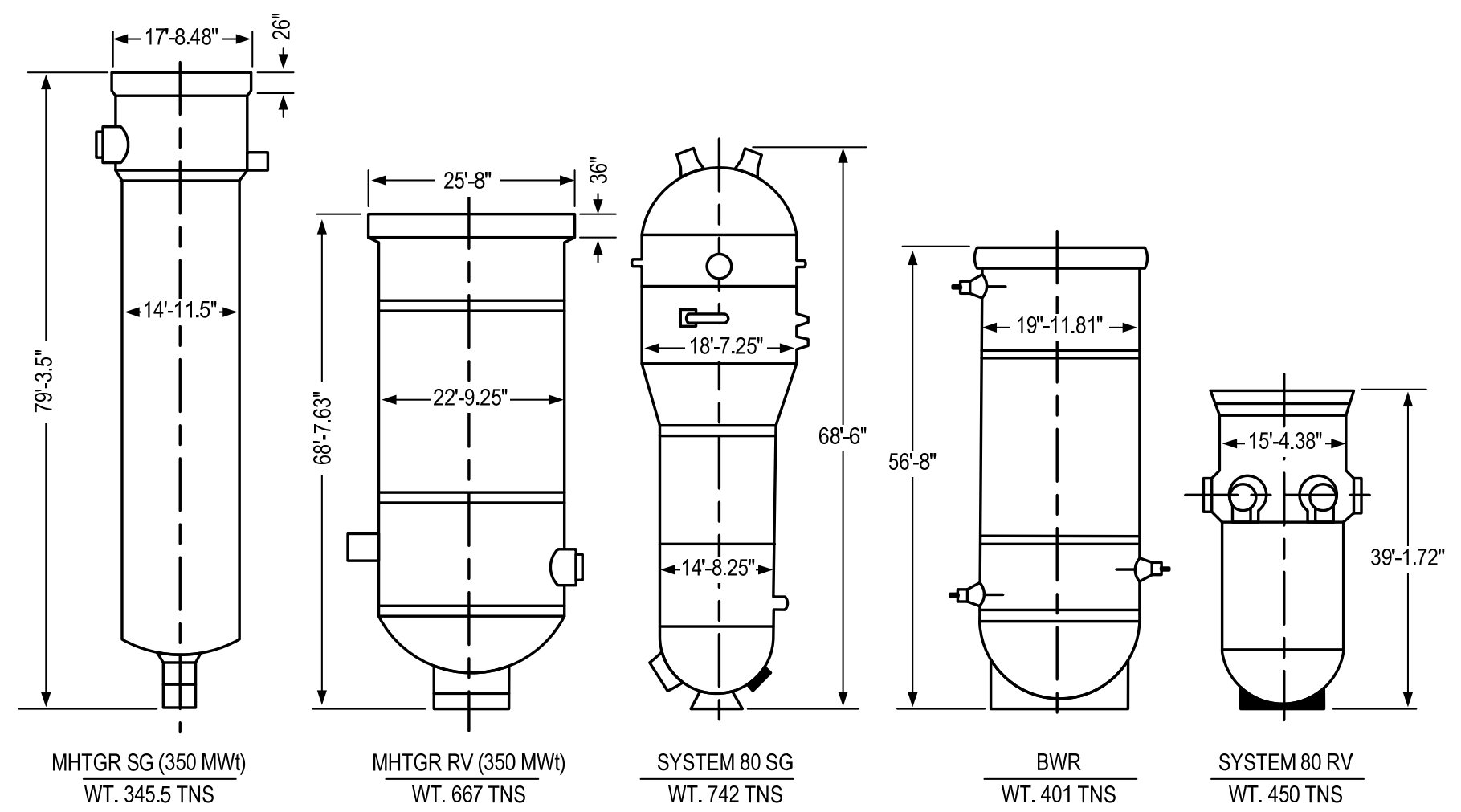

Figure 5. Comparison of MHTGR / NGNP vs. Large LWR Major Components 
Representative comparative MHTGR vs. large PWR major component dimensions and masses are shown in Table 8 below.

Table 8. MHTGR vs. Large PWR Major Component Dimensions and Masses (per Fig. 2)

\begin{tabular}{|l|c|c|c|c|c|c|c|}
\hline & \multicolumn{3}{|c|}{ MHTGR } & & \multicolumn{3}{c|}{ PWR } \\
\hline Component & $\underline{\mathrm{Ht}(\mathrm{ft})}$ & $\underline{\text { Dia (ft) }}$ & Mass (t) & & $\underline{\mathrm{Ht}(\mathrm{ft})}$ & $\underline{\text { Dia (ft) }}$ & $\underline{\text { Mass (t) }}$ \\
\hline & & & & & & & \\
\hline RPV & 72 & 24.1 & 698 & & 50 & 23 & 615 \\
\hline $\begin{array}{l}\text { SG (incl. } \\
\text { Bundle) }\end{array}$ & 83 & 16 & 514 & & 68 & 24 & 715 \\
\hline
\end{tabular}

\subsubsection{Status}

The MHTGR components have all been fabricated previously, but not on this scale (size, mass), and not recently. They all present unique fabrication challenges:

RPV and SGV - very tall

SGB - helical coil / thick wall tubes / bimetallic bundle / internal support structure

$\mathrm{CB}$ - very tall thin wall cylinder, with massive lower core support structure

No nuclear qualified vendors worldwide are currently fabricating structures similar to the CB and SG. Therefore vendors will need to be developed.

In addition, these are "one of" components (only one per module), which presents a business challenge to a potential vendor.

\subsubsection{Path Forward for NGNP}

The path forward must be to get design specifications in place for the major components, and engage potential vendors.

\subsubsection{Conclusions and Recommendations for NGNP Project}

The NGNP major components require long range planning and sufficient design finalization to initiate long term procurement (e.g., forgings, SG tubing, etc.). 


\section{NGNP INFRASTRUCTURE READINESS ASSESSMENT MATRIX}

\subsection{Description and Explanation}

The NGNP Infrastructure Readiness Assessment Matrix (Table 10) provides a list of the 36 infrastructure areas that must be considered when evaluating the readiness of the NGNP for deployment in the 2020+ timeframe. This matrix builds on previous ALWR and HTGR work where available and includes summaries of and references to previous more detailed studies. Information summarized in the matrix includes current capacity, technology development needs, and lead time. Suppliers are also included. This matrix additionally served as a screening tool to identify areas where more detailed discussion is warranted. These discussions are included in Section 4.

Appendices B and D are complements to the NGNP matrix, providing supply chain management lessons learned from deployment of Gen III+ reactors and the impact on infrastructure of the nuclear renaissance.

\subsection{Categories of Needs}

In order to give a general indication of the most critical infrastructure needs the areas were sorted into three categories. The three categories of needs in the matrix are $\mathrm{A}, \mathrm{B}$, and $\mathrm{C}$, which are generally defined as:

- Category A: Not a Significant Problem. These areas are primarily Gen III / III+ generic nuclear areas, or items which have been proven in and provided for prior HTGR construction.

- Category B: Obtainable with Advanced Planning. These items require technology development, testing, fabrication confirmation, long lead times or infrastructure expansion.

- Category C: Significant Infrastructure and/or Technical Development Required. These three (3) items require technology development and / or qualification and an adequate vendor base.

A summary of how the items in the matrix are categorized is provided in Table 9. This applies to NGNP as a FOAK (first-of-a-kind) concept with an outlet temperature of 750C. This table also applies to NOAK (Nth-of-a-kind) plants with outlet temperatures of $750 \mathrm{C}$. 
Table 9. Summary of Infrastructure Needs Categories

\begin{tabular}{|c|c|c|}
\hline Category A & Category B & Category C \\
\hline $\begin{array}{ll}\text { - } & \text { Pressure Vessel Fabrication } \\
& \text { Options } \\
\text { - } & \text { Pressure Vessel Material } \\
\text { - } & \text { Cross Vessel/Major Piping } \\
\text { - } & \text { Steam Generator Materials } \\
& \text { Techniques } \\
\text { - } & \text { Fuel Handling (Pneumatic- } \\
& \text { Pebble) } \\
\text { - } & \text { Transportation } \\
\text { - } & \text { Metallic Materials } \\
\text { - } & \text { Composite Materials } \\
\text { - } & \text { Core Ceramic Structures } \\
\text { - } & \text { Lateral Restraints \& Tie Rods } \\
\text { - } & \text { High Temperature Concrete } \\
\text { - } & \text { Rankine Cycle Steam Plant } \\
\text { - } & \text { Burnup Measurement } \\
& \text { (Pebble) } \\
\text { - Helium } \\
\text { - } \quad \text { Reserve Shutdown System } \\
\text { - } \text { Small Absorber Spheres } \\
\text { Control Rod System }\end{array}$ & $\begin{array}{ll}\text { - } & \text { RPV/Large Forgings/Nozzle } \\
& \text { Forgings } \\
\text { - } & \text { Core Barrel (w/Support Plate } \\
& \text { and Top Plate) } \\
\text { - } & \text { Steam Generator } \\
\text { - } & \text { Steam Generator Tube } \\
& \text { Bundle } \\
\text { - } & \text { Circulators } \\
\text { - } & \text { I\&C Systems } \\
\text { - } & \text { Simulator } \\
\text { - } & \text { Control Room } \\
\text { - } & \text { Integrated Testing } \\
\text { - } & \text { High Temperature Helium } \\
& \text { Valves } \\
\text { - } & \text { QA / QC Programs for HTGR } \\
& \text { Vendors } \\
\text { - } & \text { Ceramic Materials } \\
\text { - } & \text { High Temperature Insulation } \\
\text { - } & \text { I } \text { C Sensors } \\
\text { - } & \text { ISI Equipment } \\
\text { - } & \text { RCCS } \\
\text { - } & \text { Skilled Labor Force } \\
\text { - } & \text { Bellows }\end{array}$ & $\begin{array}{ll}\text { - } & \text { Fuel Assemblies (Pebbles) } \\
& \text { and Particles } \\
\text { - } & \text { Duct Liner / Hot Gas Duct } \\
\text { - } & \text { IHX and IHX Materials }\end{array}$ \\
\hline
\end{tabular}

In Table 10, there are items with two categories (e.g., Items 4b, 12 and 36). These are due primarily to the advanced materials that will be required for outlet temperatures $>900 \mathrm{C}$. 
5.3 NGNP Infrastructure Readiness Assessment Matrix

Table 10. NGNP Infrastructure Readiness Assessment Matrix

\begin{tabular}{|c|c|c|c|c|c|c|c|c|c|}
\hline & $\begin{array}{l}\text { Infrastructure Need } \\
\text { [Note where "HTGR } \\
\text { Specific"] }\end{array}$ & $\begin{array}{l}\text { Supplierl } \\
\text { Company } \\
\text { Capabilities }\end{array}$ & $\begin{array}{l}\text { Current } \\
\text { Capacity }\end{array}$ & $\begin{array}{l}\text { Readiness for } \\
\quad \text { NGNP }\end{array}$ & $\begin{array}{l}\text { Technology } \\
\text { Development } \\
\text { Needs }\end{array}$ & $\begin{array}{l}\text { Notes (Lead Time, } \\
\text { etc.) }\end{array}$ & Supplier Contact & $\begin{array}{l}\text { Document } \\
\text { References }\end{array}$ & $\begin{array}{l}\text { Comments / Recommendations / etc. } \\
\text { Expansion Capability / Plans }\end{array}$ \\
\hline $1 \mathrm{a}$. & $\begin{array}{l}\text { Pressure Vessel } \\
\text { Fabrication Options } \\
\text { (Forged rings; } \\
\text { Welded rolled plate) } \\
\text { for Reactor Pressure } \\
\text { Vessel (RPV) }\end{array}$ & $\begin{array}{l}\text { Toshiba } \\
\text { Corporation, } \\
\text { Ansaldo } \\
\text { Camozzi, } \\
\text { Doosan Heavy } \\
\text { Industries, } \\
\text { Equipos } \\
\text { Nucleares, S.A. } \\
\text { (ENSA), Hitachi, } \\
\text { Ishikawajimi- } \\
\text { Harima Heavy } \\
\text { Industries now } \\
\text { IHI Corporation, } \\
\text { Mitsubishi } \\
\text { Heavy Industries } \\
\text { (MHI), Japan } \\
\text { Casting and } \\
\text { Forge Company } \\
\text { (JCFC), China } \\
\text { First Heavy } \\
\text { Industries, } \\
\text { China Erzhong, } \\
\text { OMZ Izhora } \\
\text { (Russia) } \\
\text { American Tank } \\
\text { and Fabrication, } \\
\text { Nuclear - } \\
\text { Cleveland, OH, } \\
\text { Precision } \\
\text { Custom } \\
\text { Components - } \\
\text { York, PA and } \\
\text { Newport News, } \\
\text { VA - AREVA } \\
\text { Consortium, } \\
\text { Chicago Bridge } \\
\text { and Iron } \\
\text { (recently } \\
\text { renewed their N- }\end{array}$ & $\begin{array}{l}\text { Multiple } \\
\text { suppliers have } \\
\text { the capability to } \\
\text { fabricate an } \\
\text { NGNP RPV. } \\
\text { Forgings are } \\
\text { preferred due to } \\
\text { less welding and } \\
\text { subsequent non- } \\
\text { destructive } \\
\text { examinations. }\end{array}$ & $\begin{array}{l}\text { A } \\
\text { As for LWRs }\end{array}$ & None & $\begin{array}{l}10 \text { year total lead } \\
\text { time } \\
\text { (5-6 year advance } \\
\text { reservations for } \\
\text { forgings and } 3-4 \\
\text { years to produce } \\
\text { final product) } \\
\text { Lead times will vary } \\
\text { depending on } \\
\text { demand. }\end{array}$ & $\begin{array}{l}\text { Doosan Heavy } \\
\text { Industries, H.K. Kang, } \\
\text { 724-722-5215 }\end{array}$ & $\begin{array}{l}\text { [1] (sections 6.1- } \\
6.2 \text {, } \\
{[5] \text { (sections 6.4- }} \\
6.5) \text {, } \\
\text { [9] (sections 2-4), } \\
{[13] \text { (sections } 2 \text { and }} \\
4, \text { Appendix C), } \\
\text { [24] }\end{array}$ & $\begin{array}{l}\text { - Consider welded rolled plate to avoid the fabrication bottleneck } \\
\text { and transportation difficulties to the INL site } \\
\text { - Confirm ASME code status } \\
\text { - For Nth of a kind where the site is assumed to be US Gulf Coast } \\
\text { with barge access, forged rings are a possibility as the } \\
\text { transportation constraints are much less stringent } \\
\text { - Work with vessel fabricators to ascertain the delivery schedule for } \\
\text { the heavy section materials and the completed components to } \\
\text { the INL site (particularly for the more constraining FOAK site } \\
\text { assumed to be INL) } \\
\text { - Work with vessel fabricator to ensure correct assembly of these } \\
\text { vessels (proper welding and heat treatment procedures) } \\
\text { assuming on-site fabrication }\end{array}$ \\
\hline
\end{tabular}




\begin{tabular}{|c|c|c|c|c|c|c|c|c|c|}
\hline & $\begin{array}{l}\text { Infrastructure Need } \\
\text { [Note where "HTGR } \\
\text { Specific"] }\end{array}$ & $\begin{array}{l}\text { Supplierl } \\
\text { Company } \\
\text { Capabilities }\end{array}$ & $\begin{array}{l}\text { Current } \\
\text { Capacity }\end{array}$ & $\begin{array}{l}\text { Readiness for } \\
\text { NGNP }\end{array}$ & $\begin{array}{l}\text { Technology } \\
\text { Development } \\
\text { Needs }\end{array}$ & $\begin{array}{l}\text { Notes (Lead Time, } \\
\text { etc.) }\end{array}$ & Supplier Contact & $\begin{array}{l}\text { Document } \\
\text { References }\end{array}$ & $\begin{array}{l}\text { Comments / Recommendations / etc. } \\
\text { Expansion Capability / Plans }\end{array}$ \\
\hline & & stamps). & & & & & & & \\
\hline
\end{tabular}




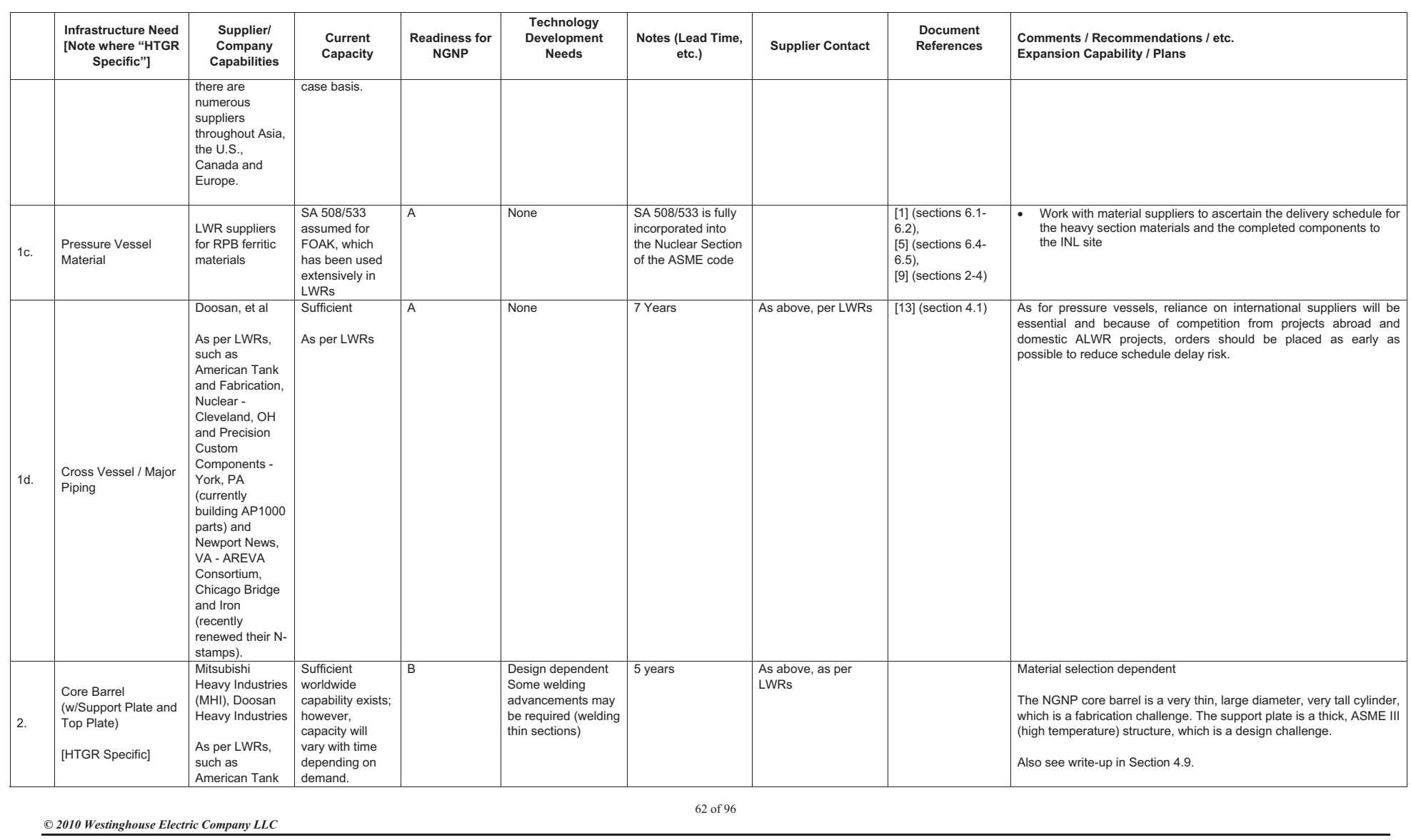




\begin{tabular}{|c|c|c|c|c|c|c|c|c|c|}
\hline & $\begin{array}{c}\text { Infrastructure Need } \\
\text { [Note where "HTGR } \\
\text { Specific"] }\end{array}$ & $\begin{array}{l}\text { Supplier/ } \\
\text { Company } \\
\text { Capabilities }\end{array}$ & $\begin{array}{l}\text { Current } \\
\text { Capacity }\end{array}$ & $\begin{array}{l}\text { Readiness for } \\
\text { NGNP }\end{array}$ & $\begin{array}{l}\text { Technology } \\
\text { Development } \\
\text { Needs }\end{array}$ & $\begin{array}{l}\text { Notes (Lead Time, } \\
\text { etc.) }\end{array}$ & Supplier Contact & $\begin{array}{l}\text { Document } \\
\text { References }\end{array}$ & $\begin{array}{l}\text { Comments / Recommendations / etc. } \\
\text { Expansion Capability / Plans }\end{array}$ \\
\hline & & $\begin{array}{l}\text { and Fabrication, } \\
\text { Nuclear - } \\
\text { Cleveland, OH } \\
\text { and Precision } \\
\text { Custom } \\
\text { Components - } \\
\text { York, PA } \\
\text { (currently } \\
\text { building AP1000 } \\
\text { parts) and } \\
\text { Newport News, } \\
\text { VA - AREVA } \\
\text { Consortium, } \\
\text { Chicago Bridge } \\
\text { and Iron } \\
\text { (recently } \\
\text { renewed their N- } \\
\text { stamps). }\end{array}$ & As per LWRs & & & & & & \\
\hline 3. & $\begin{array}{l}\text { Steam Generator } \\
\text { (single) } \\
\text { [HTGR Specific] }\end{array}$ & $\begin{array}{l}\text { Doosan, others } \\
\text { As per PWRs, } \\
\text { such as } \\
\text { American Tank } \\
\text { and Fabrication, } \\
\text { Nuclear - } \\
\text { Cleveland, OH } \\
\text { and Precision } \\
\text { Custom } \\
\text { Components - } \\
\text { York, PA } \\
\text { (currently } \\
\text { building AP1000 } \\
\text { parts) and } \\
\text { Newport News, } \\
\text { VA - AREVA } \\
\text { Consortium, } \\
\text { Chicago Bridge } \\
\text { and Iron } \\
\text { (recently } \\
\text { renewed their N- } \\
\text { stamps). }\end{array}$ & None in place & B & $\begin{array}{l}\text { Testing, including } \\
\text { welding }\end{array}$ & 5 Years & As above & & $\begin{array}{l}\text { Single loop per SOW } \\
\text { Initiate testing } \\
\text { Since this is a one-per-unit component (like the Circulator) it is most } \\
\text { likely that a single supplier will need to be qualified for NGNP, without } \\
\text { the assurance of near term additional orders. } \\
\text { Also see write-up in Section } 4.9 \text {. }\end{array}$ \\
\hline 3a. & $\begin{array}{l}\text { Steam Generator } \\
\text { Materials } \\
\text { [HTGR Specific] }\end{array}$ & Numerous & $\begin{array}{l}\text { Adequate as } \\
\text { nickel base } \\
\text { metal demand } \\
\text { and price have } \\
\end{array}$ & A & None & 5 Years & As per PWRs & & \\
\hline
\end{tabular}




\begin{tabular}{|c|c|c|c|c|c|c|c|c|}
\hline $\begin{array}{l}\text { Infrastructure Need } \\
\text { [Note where "HTGR } \\
\text { Specific"] }\end{array}$ & $\begin{array}{l}\text { Supplier/ } \\
\text { Company } \\
\text { Capabilities }\end{array}$ & $\begin{array}{l}\text { Current } \\
\text { Capacity }\end{array}$ & $\begin{array}{l}\text { Readiness for } \\
\text { NGNP }\end{array}$ & $\begin{array}{l}\text { Technology } \\
\text { Development } \\
\text { Needs }\end{array}$ & $\begin{array}{l}\text { Notes (Lead Time, } \\
\text { etc.) }\end{array}$ & Supplier Contact & $\begin{array}{l}\text { Document } \\
\text { References }\end{array}$ & $\begin{array}{l}\text { Comments / Recommendations / etc. } \\
\text { Expansion Capability / Plans }\end{array}$ \\
\hline & & $\begin{array}{l}\text { both eased after } \\
\text { record highs in } \\
\text { the } 2006-2007 \\
\text { period }\end{array}$ & & & & & & \\
\hline $\begin{array}{l}\text { SG Tube Bundle } \\
\text { [HTGR Specific] }\end{array}$ & $\begin{array}{l}\text { Doosan, others } \\
\text { As per PWRs, } \\
\text { such as } \\
\text { American Tank } \\
\text { and Fabrication, } \\
\text { Nuclear - } \\
\text { Cleveland, OH } \\
\text { and Precision } \\
\text { Custom } \\
\text { Components - } \\
\text { York, PA } \\
\text { (currently } \\
\text { building AP1000 } \\
\text { parts) and } \\
\text { Newport News, } \\
\text { VA-AREVA } \\
\text { Consortium, } \\
\text { Chicago Bridge } \\
\text { and Iron } \\
\text { (recently } \\
\text { renewed their N- } \\
\text { stamps). }\end{array}$ & None in place & B & $\begin{array}{l}\text { Testing and } \\
\text { fabrication, } \\
\text { including bending } \\
\text { and welding }\end{array}$ & 5 Years & $\begin{array}{l}\text { As above as per } \\
\text { PWRs }\end{array}$ & & $\begin{array}{l}\text { Initiate fabrication testing } \\
\text { The HTGR SG is not a PWR design (helical coil vs. U-tube). } \\
\text { Numerous design and fabrication challenges need to be addressed. }\end{array}$ \\
\hline $\begin{array}{l}\text { Circulators } \\
\text { (single loop per } \\
\text { SOW) } \\
\text { [HTGR Specific] }\end{array}$ & $\begin{array}{l}\text { Howden UK } \\
\text { most credible }\end{array}$ & $\begin{array}{l}\text { Capacity } \\
>\text { need }\end{array}$ & $\begin{array}{l}\text { B (due to serial } \\
\text { schedule with } \\
\text { key decision } \\
\text { points) }\end{array}$ & $\begin{array}{l}\text { Test prototype in a } \\
\text { helium loop (only } \\
\text { way to verify } \\
\text { integrated design) }\end{array}$ & $\begin{array}{l}\text { 7 yrs time required } \\
\text { to complete } \\
\text { Yr1 Mat/comp } \\
\text { Yr2 Design } \\
\text { Yr3 Bld Proto } \\
\text { Yr4 Test Proto } \\
\text { Yr5 Test \& Bld } \\
\text { Yr6 Qual Final } \\
\text { Yr7 Qual \& Bld } \\
\text { NGNP circulator(s) } \\
\text { (This is an } \\
\text { optimistic schedule } \\
\text { - Skip step = add } \\
\text { risk) }\end{array}$ & $\begin{array}{l}\text { Sam Strahan } \\
\text { Howden } \\
\text { UK }\end{array}$ & $\begin{array}{l}\text { Documents on } \\
100 \mathrm{~kW} \text { blower of } \\
\text { this design as used } \\
\text { in the HTF (South } \\
\text { Africa) } \\
\text { [18], [19], [20] }\end{array}$ & $\begin{array}{l}\text { Submerged motor with AMBs (Active Magnetic Bearings), limit will be } \\
\text { power transmitted through pressure boundary and motor cooling and } \\
\text { insulation. } \\
\text { Fallback is external motor with DGS (Dry Gas Seals). } \\
\text { The risk of twin circulators is not necessarily substantially lower } \\
\text { (same failure mechanisms). } \\
\text { It is important to determine a design requirement for circulators. } \\
\text { Based on this, probable configurations can be defined. } \\
\text { The configuration selection will determine the necessary bench } \\
\text { and aging tests. } \\
\text { Select the partner-supplier }\end{array}$ \\
\hline
\end{tabular}




\begin{tabular}{|c|c|c|c|c|c|c|c|c|c|}
\hline & $\begin{array}{l}\text { Infrastructure Need } \\
\text { [Note where "HTGR } \\
\text { Specific"] }\end{array}$ & $\begin{array}{l}\text { Supplierl } \\
\text { Company } \\
\text { Capabilities }\end{array}$ & $\begin{array}{l}\text { Current } \\
\text { Capacity }\end{array}$ & $\begin{array}{l}\text { Readiness for } \\
\text { NGNP }\end{array}$ & $\begin{array}{l}\text { Technology } \\
\text { Development } \\
\text { Needs }\end{array}$ & $\begin{array}{l}\text { Notes (Lead Time, } \\
\text { etc.) }\end{array}$ & Supplier Contact & $\begin{array}{l}\text { Document } \\
\text { References }\end{array}$ & $\begin{array}{l}\text { Comments / Recommendations / etc. } \\
\text { Expansion Capability / Plans }\end{array}$ \\
\hline & & & & & & & & & $\begin{array}{l}\text { Develop \& test a prototype circulator. } \\
\text { Also see write-up in Section } 4.2 \text { and Appendix C. }\end{array}$ \\
\hline 4a. & Circulator Design & $\begin{array}{l}\text { Howden, } \\
\text { MHI }\end{array}$ & $\begin{array}{l}\text { Capacity } \\
>\text { need }\end{array}$ & A & & $\begin{array}{l}\text { Modern design } \\
\text { tools yield good } \\
\text { results. } \\
\text { Single work point } \\
\text { yields best } \\
\text { optimization. }\end{array}$ & & [18], [19] & $\begin{array}{l}\text { A long straight inlet ensures better performance, avoids rotating stall. } \\
\text { Integrated design key to success. } \\
\text { AMB/DGSs exclude long overhang design. } \\
\text { Important to consider circulator replacement procedure in concept. }\end{array}$ \\
\hline 4b. & $\begin{array}{l}\text { Impeller Materials } \\
\text { and/or Coatings }\end{array}$ & $\begin{array}{l}\text { Circulator } \\
\text { vendor acquires } \\
\text { material }\end{array}$ & $\begin{array}{l}\text { Capacity } \\
>\text { need }\end{array}$ & $\begin{array}{l}\mathrm{A}<350^{\circ} \mathrm{C} \\
\mathrm{B}>450^{\circ} \mathrm{C}\end{array}$ & $\begin{array}{l}\text { Qualify } \\
\text { material/coating to } \\
\text { mitigate risk of } \\
\text { decarburization = } \\
\text { embrittlement. }\end{array}$ & $\begin{array}{l}\text { Titanium known to } \\
\text { work to } 350^{\circ} \mathrm{C} \text {. } \\
\text { Overkill for slow } \\
\text { impeller. }\end{array}$ & & & $\begin{array}{l}\text { Consider Ejectors (primary flow circuit entraining secondary } \\
\text { Hydrogen circuit flow) if T return is }>500^{\circ} \mathrm{C} \\
\text { Current experience is } 350^{\circ} \mathrm{C}\end{array}$ \\
\hline 4c. & Motor Design & $\begin{array}{l}\text { Once designed } \\
\text { any vendor in } \\
\text { sector can } \\
\text { manufacture } \\
\text { motor. }\end{array}$ & $\begin{array}{l}\text { Capacity } \\
>\text { need }\end{array}$ & A & & $\begin{array}{l}\text { A too large speed } \\
\text { range makes } \\
\text { blower cooling } \\
\text { design a challenge. }\end{array}$ & & & $\begin{array}{l}\text { If Submerged - Integrated cooler in stator. } \\
\text { Good rotor stiffness, well balanced design. }\end{array}$ \\
\hline 4d. & $\begin{array}{l}\text { Circulator Bearings } \\
\text { Submerged - Active } \\
\text { Magnetic Bearings } \\
\text { (AMB), gas, catcher } \\
\text { Non-submerged - } \\
\text { Oil, Roller }\end{array}$ & $\begin{array}{l}\text { SKF, } \\
\text { Waukesha, S2M }\end{array}$ & $\begin{array}{l}\text { Capacity } \\
>\text { need }\end{array}$ & A & Testing & $\begin{array}{l}\text { Test catcher } \\
\text { bearings } \\
\text { Test AMB at size } \\
\text { needed }\end{array}$ & & & $\begin{array}{l}\text { AMBs make for 'softer' surging; however they add about } 120 \text { signal } \\
\text { penetrations to containment vessel. }\end{array}$ \\
\hline 4e. & $\begin{array}{l}\text { Electrical Insulation } \\
\text { (Motors \& AMB) }\end{array}$ & $\begin{array}{l}\text { Various mineral } \\
\text { insulations }\end{array}$ & $\begin{array}{l}\text { Capacity } \\
>\text { need }\end{array}$ & A & $\begin{array}{l}\text { Test with } \\
\text { accelerated aging in } \\
\text { coil form in Helium } \\
\text { at P/T (add } \\
\text { vibration) }\end{array}$ & $\begin{array}{l}\text { Must be tested in } \\
\text { realistic conditions. } \\
\text { HTF failure was due } \\
\text { to bad binder } \\
\text { ingress = } \\
\text { manufacturing } \\
\text { process or quality }\end{array}$ & & & Significant dielectric losses and flash-over risk at high power (>8MW) \\
\hline $4 \mathrm{f}$. & $\begin{array}{l}\text { AMB } \\
\text { Instrumentation }\end{array}$ & $\begin{array}{l}\text { (Part of bearing } \\
\text { supply ) }\end{array}$ & $\begin{array}{l}\text { Capacity } \\
>\text { need }\end{array}$ & A & & & & & $\begin{array}{l}\text { Comment - There is not room in an AMB for redundancy. Redundant } \\
\text { AMBs add to rotor flex which causes more problems than it solves. If } \\
\text { the circulation function requires redundancy it would have to be } \\
\text { achieved in the whole circulator, and not in the component. }\end{array}$ \\
\hline $4 \mathrm{~g}$. & $\begin{array}{l}\text { Dry Gas Seals } \\
\text { (DGS) } \\
\text { (Fallback if not }\end{array}$ & $\begin{array}{l}\text { John Crane, et } \\
\text { al }\end{array}$ & $\begin{array}{l}\text { Capacity } \\
>\text { need }\end{array}$ & A & & $\begin{array}{l}\text { Cannot be used } \\
\text { with AMBs in } \\
\text { overhung }\end{array}$ & & & $\begin{array}{l}\text { Our fallback option is within technology available. Consider back- } \\
\text { stop DGS with N2 vessel to reduce thrust load. }\end{array}$ \\
\hline
\end{tabular}




\begin{tabular}{|c|c|c|c|c|c|c|c|c|c|}
\hline & $\begin{array}{l}\text { Infrastructure Need } \\
\text { [Note where "HTGR } \\
\text { Specific"] }\end{array}$ & $\begin{array}{l}\text { Supplierl } \\
\text { Company } \\
\text { Capabilities }\end{array}$ & $\begin{array}{l}\text { Current } \\
\text { Capacity }\end{array}$ & $\begin{array}{l}\text { Readiness for } \\
\text { NGNP }\end{array}$ & $\begin{array}{l}\text { Technology } \\
\text { Development } \\
\text { Needs }\end{array}$ & $\begin{array}{l}\text { Notes (Lead Time, } \\
\text { etc.) }\end{array}$ & Supplier Contact & $\begin{array}{l}\text { Document } \\
\text { References }\end{array}$ & $\begin{array}{l}\text { Comments / Recommendations / etc. } \\
\text { Expansion Capability / Plans }\end{array}$ \\
\hline & submerged) & & & & & $\begin{array}{l}\text { configuration. } \\
\text { Clearance } \\
\text { requirement too } \\
\text { strict. }\end{array}$ & & & \\
\hline 4h. & $\begin{array}{l}\text { Electrical } \\
\text { Penetrations } \\
\text { (Power \& } \\
\text { Instruments) }\end{array}$ & $\begin{array}{l}\text { Schott } \\
\text { (Germany), } \\
\text { Mirion } \\
\text { Technologies, } \\
\text { and others }\end{array}$ & $\begin{array}{l}\text { Capacity } \\
>\text { need }\end{array}$ & A & Testing & $\begin{array}{l}\text { Test to see limit of } \\
\text { reliable power } \\
\text { transference in } \\
\text { helium. } \\
\text { Test dust shields. } \\
\text { The Penetrations } \\
\text { are set on vessel } \\
\text { 'ears' since they } \\
\text { typically don't like } \\
\text { heat. Target T } \\
100^{\circ} \mathrm{C}\end{array}$ & & Schott and IST & $\begin{array}{l}\text { The ability to transfer power and signals through the Pressure } \\
\text { Boundary in helium and graphite dust is key to a submerged AMB } \\
\text { circulator, and can be the factor that limits size. }\end{array}$ \\
\hline 5. & $\begin{array}{l}\text { I\&C Systems } \\
\text { (including Digital } \\
\text { Control Systems, } \\
\text { OCS, RPS...) } \\
\text { [HTGR Specific] }\end{array}$ & $\begin{array}{l}\text { Westinghouse } \\
\text { Nuclear } \\
\text { Automation }\end{array}$ & $\begin{array}{l}\text { Capacity } \\
\text { currently } \\
\text { exceeds need } \\
\text { but may vary } \\
\text { depending on } \\
\text { demand from } \\
\text { other projects }\end{array}$ & B & $\begin{array}{l}\text { Yes, for NRC } \\
\text { approval }\end{array}$ & 5-9 Years & $\begin{array}{l}\text { Westinghouse } \\
\text { Nuclear Automation }\end{array}$ & [13] & $\begin{array}{l}\text { Similar to LWRs, design and NRC approval of digital plant control } \\
\text { systems will be time consuming } \\
\text { All I\&C used for the NGNP should be standard Nuclear Power Plant } \\
\text { technology. } \\
\text { Environmental Qualification (EQ) of some instrumentation may be } \\
\text { required due to specific NGNP environmental conditions and } \\
\text { requirements. }\end{array}$ \\
\hline 6. & $\begin{array}{l}\text { Simulator } \\
\text { [HTGR Specific] }\end{array}$ & $\begin{array}{l}\text { Westinghouse } \\
\text { Nuclear } \\
\text { Automation, } \\
\text { GSE Systems }\end{array}$ & $\begin{array}{l}\text { Capacity } \\
\text { currently } \\
\text { exceeds need } \\
\text { but may vary } \\
\text { depending on } \\
\text { demand from } \\
\text { other projects }\end{array}$ & B & & 5-9 Years & $\begin{array}{l}\text { Westinghouse } \\
\text { Nuclear Automation }\end{array}$ & & Special order, with NGNP-HTGR system software \\
\hline 7. & $\begin{array}{l}\text { Control Room } \\
\text { [HTGR Specific] }\end{array}$ & $\begin{array}{l}\text { Westinghouse } \\
\text { Nuclear } \\
\text { Automation, } \\
\text { Siemens, ABB- } \\
\text { US, Emerson, } \\
\text { others }\end{array}$ & $\begin{array}{l}\text { Capacity } \\
\text { currently } \\
\text { exceeds need } \\
\text { but may vary } \\
\text { depending on } \\
\text { demand from } \\
\text { other projects }\end{array}$ & B & & 5-9 Years & $\begin{array}{l}\text { Westinghouse } \\
\text { Nuclear Automation }\end{array}$ & & NRC approvals required \\
\hline 8. & $\begin{array}{l}\text { Integrated Testing } \\
\text { (how / where to test } \\
\text { FOAK components) }\end{array}$ & $\begin{array}{l}\text { M-Tech } \\
\text { Industrial, } \\
\text { WE-SA }\end{array}$ & $\begin{array}{l}\text { Standard } \\
\text { Industrial } \\
\text { components }\end{array}$ & B & $\begin{array}{l}\text { Configured from } \\
\text { standard industrial } \\
\text { practice to avoid } \\
\text { test loop }\end{array}$ & $\begin{array}{l}4 \text { Years to design, } \\
\text { build \& commission. } \\
3 \text { years to complete } \\
\text { component testing }\end{array}$ & $\begin{array}{l}\text { M-Tech Industrial: } \\
+27(0) 182970326 \\
\text { +27(0)182970327 } \\
\text { info@mtechindustrial. }\end{array}$ & & $\begin{array}{l}\text { Necessary to Reduce FOAK Uncertainties. } \\
\text { WESA designed, built and commissioned the HTF facility in South } \\
\text { Africa. }\end{array}$ \\
\hline
\end{tabular}




\begin{tabular}{|c|c|c|c|c|c|c|c|c|c|}
\hline & $\begin{array}{c}\text { Infrastructure Need } \\
\text { [Note where "HTGR } \\
\text { Specific"] }\end{array}$ & $\begin{array}{l}\text { Supplier/ } \\
\text { Company } \\
\text { Capabilities }\end{array}$ & $\begin{array}{l}\text { Current } \\
\text { Capacity }\end{array}$ & $\begin{array}{l}\text { Readiness for } \\
\quad \text { NGNP }\end{array}$ & $\begin{array}{l}\text { Technology } \\
\text { Development } \\
\text { Needs }\end{array}$ & $\begin{array}{l}\text { Notes (Lead Time, } \\
\text { etc.) }\end{array}$ & Supplier Contact & $\begin{array}{l}\text { Document } \\
\text { References }\end{array}$ & $\begin{array}{l}\text { Comments / Recommendations / etc. } \\
\text { Expansion Capability / Plans }\end{array}$ \\
\hline & [HTGR Specific] & & & & development & & $\begin{array}{l}\text { com } \\
\text { WESA: } \\
\text { Highway Business } \\
\text { Park } \\
\text { Centurion, South } \\
\text { Africa }\end{array}$ & & See HTF write-up in Appendix A. \\
\hline 9. & $\begin{array}{l}\text { Construction } \\
\text { Capabilities \& } \\
\text { Techniques } \\
\text { (including } \\
\text { Modularization) }\end{array}$ & $\begin{array}{l}\text { Shaw, other } \\
\text { EPC contractors } \\
\text { and NSSS } \\
\text { vendors, as well } \\
\text { as module } \\
\text { fabricators; } \\
\text { various } \\
\text { suppliers for } \\
\text { specialized } \\
\text { construction } \\
\text { equipment } \\
\text { General } \\
\text { Dynamics } \\
\text { Electric Boat } \\
\text { Division }\end{array}$ & $\begin{array}{l}\text { Multiple } \\
\text { suppliers with } \\
\text { nuclear QA/QC } \\
\text { procedures and } \\
\text { experience, } \\
\text { particularly after } \\
\text { ALWR } \\
\text { construction in } \\
\text { the US } \\
\text { progresses. }\end{array}$ & A & None & $\begin{array}{l}\text { Before } \\
\text { modularization can } \\
\text { be completed the } \\
\text { engineering must } \\
\text { be completed. } \\
\text { Modularizing the } \\
\text { design could take } \\
\text { up to a year after } \\
\text { engineering is } \\
\text { completed. } \\
>2 \text { Years }\end{array}$ & $\begin{array}{l}\text { Charles Besselman, } \\
\text { Fabrication/Manufact } \\
\text { uring Engineering } \\
\text { Manager, 225-368- } \\
\text { 2619, } \\
\text { Charles.besselman@ } \\
\text { shawgrp.com, 3191 } \\
\text { W. Lincoln Road, } \\
\text { Lake Charles, LA } \\
70605\end{array}$ & [13] (Section 5) & $\begin{array}{l}\text { - Once the engineering is completed, commence modularizing the } \\
\text { design for the FOAK site } \\
\text { - Modularizing for the Nth of a kind site would likely be less } \\
\text { constraining than the FOAK site } \\
\text { - Determine number of modules and types of modules } \\
\text { - Rely on the nuclear construction labor and QA/QC infrastructure } \\
\text { that will result from the upcoming ALWR construction activities in } \\
\text { the US } \\
\text { - The Shaw Modularization Solutions modular fabrication facility } \\
\text { located on the Port of Lake Charles in Louisiana opened in } \\
\text { February } 2010 \text { and is a state of the art } 410,000 \text { square foot } \\
\text { waterfront facility with truck, barge and rail access. It is located } \\
\text { on } 120 \text { acres (with the option to expand to a total of } 300 \text { acres), } \\
\text { has } 7 \text { production bays, an } 8,200 \text { square foot administrative } \\
\text { building, and a } 10,000 \text { square floor training facility. The facility } \\
\text { has an ASME NQA-1 program and produces structural, piping, } \\
\text { and equipment modules for nuclear power plants (more specific } \\
\text { module types include raceway, pump/valve, and depressurization } \\
\text { modules). The modules consist of sub-modules that are } \\
\text { produced and assembled at the facility. For example, structural } \\
\text { sub-modules for the AP1000 include L-shapes, flat panels, T- } \\
\text { shapes, and floor plates (an example of a complete structural } \\
\text { module is one that is comprised of } 72 \text { sub-modules). Sub-module } \\
\text { fabrication typically consists of numerous steps, including: } \\
\text { blasting, plate welding, plate marking and laser cutting, stiffener } \\
\text { welding, stud welding, mounting, assembly/outfitting, painting, } \\
\text { cleaning, shipping preparation, and shipping, with inspection } \\
\text { between the majority of the steps. }\end{array}$ \\
\hline 10a. & $\begin{array}{l}\text { Fuel Assemblies } \\
\text { (Pebbles) } \\
\text { [HTGR Specific] }\end{array}$ & $\begin{array}{l}\text { NFI (Japan); } \\
\text { B\&W / NFS } \\
\text { (US) }\end{array}$ & Minimal & C & $\begin{array}{l}\text { Complete the } \\
\text { NGNP Fuel } \\
\text { Qualification } \\
\text { Program } \\
\text { Then qualify a fuel } \\
\text { fabrication facility }\end{array}$ & $>5$ Years & & [12] & $\begin{array}{l}\text { PBMR South Africa fuel facility not available - Vendor and capacity } \\
\text { for pebbles to be established } \\
\text { At the present time, there is no HTGR fuel supplier in the U.S. (or } \\
\text { worldwide) that has the capability to produce UO2 / UCO fuel } \\
\text { particles or assemblies / pebbles on a large scale for NGNP. } \\
\text { More details in Reference } 12 \text {. }\end{array}$ \\
\hline 10b. & $\begin{array}{l}\text { Fuel Particles (UO2; } \\
\text { UCO) } \\
\text { [HTGR Specific] }\end{array}$ & $\begin{array}{l}\text { B\&W / NFS (US) } \\
\text { NFI (Japan) }\end{array}$ & Minimal & C & $\begin{array}{l}\text { Complete the } \\
\text { NGNP Fuel } \\
\text { Qualification }\end{array}$ & 5 Years & & [12] & $\begin{array}{l}\text { PBMR South Africa particle fuel facility not available - Vendor } \\
\text { capacity to be established } \\
\text { At the present time, there is no HTGR fuel supplier in the U.S. (or }\end{array}$ \\
\hline
\end{tabular}




\begin{tabular}{|c|c|c|c|c|c|c|c|c|c|}
\hline & $\begin{array}{l}\text { Infrastructure Need } \\
\text { [Note where "HTGR } \\
\text { Specific"] }\end{array}$ & $\begin{array}{l}\text { Supplier/ } \\
\text { Company } \\
\text { Capabilities }\end{array}$ & $\begin{array}{l}\text { Current } \\
\text { Capacity }\end{array}$ & $\begin{array}{l}\text { Readiness for } \\
\text { NGNP }\end{array}$ & $\begin{array}{l}\text { Technology } \\
\text { Development } \\
\text { Needs }\end{array}$ & $\begin{array}{l}\text { Notes (Lead Time, } \\
\text { etc.) }\end{array}$ & Supplier Contact & $\begin{array}{l}\text { Document } \\
\text { References }\end{array}$ & $\begin{array}{l}\text { Comments / Recommendations / etc. } \\
\text { Expansion Capability / Plans }\end{array}$ \\
\hline & & & & & $\begin{array}{l}\text { Program } \\
\text { Then qualify a fuel } \\
\text { fabrication facility }\end{array}$ & & & & $\begin{array}{l}\text { worldwide) that has the capability to produce UO2 / UCO fuel } \\
\text { particles or assemblies / pebbles on a large scale for NGNP. } \\
\text { Higher enrichment than LWRs ( } 7-9 \% \text { vs } 3-5 \%) \\
\text { More details in Reference } 29 \text {. }\end{array}$ \\
\hline 11. & $\begin{array}{l}\text { Fuel Handling } \\
\text { (Pneumatic-Pebble) } \\
\text { [HTGR Specific] }\end{array}$ & WE-SA & $\begin{array}{l}\text { System } \\
\text { developed for } \\
\text { PBMR. } \\
\text { Performance } \\
\text { verified by test }\end{array}$ & A & $\begin{array}{l}\text { Functional } \\
\text { performance } \\
\text { confirmed. Nuclear } \\
\text { Qualification } \\
\text { expected. ASME } \\
\text { Component Design }\end{array}$ & $\begin{array}{l}\text { Forging for Core } \\
\text { Unloading Device } \\
\text { \& special ribbed } \\
\text { pipes are long lead } \\
\text { items. } \\
3-4 \text { years to } \\
\text { deliver a new } \\
\text { qualified system. }\end{array}$ & $\begin{array}{l}\text { WESA } \\
\text { Highway Business } \\
\text { Park } \\
\text { Centurion, South } \\
\text { Africa }\end{array}$ & & \\
\hline 12. & $\begin{array}{l}\text { High Temperature } \\
\text { Helium Valves (fast } \\
\text { closing; control) } \\
\text { [HTGR Specific] }\end{array}$ & $\begin{array}{l}\text { VELAN, } \\
\text { Target Rock } \\
\text { (Curtis Wright), } \\
\text { Broady Flow } \\
\text { Control, } \\
\text { Segault SA }\end{array}$ & $\begin{array}{l}\text { LWR Suppliers. } \\
\text { Off the shelf. } \\
610^{\circ} \mathrm{C} \text { upper } \\
\text { Limit } \\
347 \text { material. } \\
\text { Current } \\
\text { production rate } \\
\text { may not be } \\
\text { sufficient. }\end{array}$ & $\begin{array}{l}B<610 C \\
C>610 C \text {, or } \\
\text { Class } 6 \text { many } \\
\text { cycles }\end{array}$ & $\begin{array}{l}\text { Development } \\
\text { necessary for } \\
\text { temperatures above } \\
610^{\circ} \mathrm{C} \text { or leak } \\
\text { tightness of Class } 6 \\
\text { for many cycles. }\end{array}$ & $\begin{array}{l}7 \text { Years, for } \\
\text { castings } \\
\text { Lead time: } \approx 9-12 \\
\text { months }\end{array}$ & $\begin{array}{l}\text { VELAN } \\
94 \text { Avenue C } \\
\text { Williston, VT } \\
\text { 05495-9732 } \\
\text { USA }\end{array}$ & [13] (Table 4.3) & $\begin{array}{l}\text { Helium Leak tightness potential problem. Class } 6 \text { available but not } \\
\text { for many cycles. Leakage past valve stem can be solved with } \\
\text { bellows, but only for limited cycles. } \\
\text { See the write-ups in Section } 4.4 \text { and Appendix A. }\end{array}$ \\
\hline 13. & $\begin{array}{l}\text { QA / QC Programs in } \\
\text { place for potential } \\
\text { HTGR vendors }\end{array}$ & & & B & None & 8 Years & $\mathrm{N} / \mathrm{A}$ & $\begin{array}{l}\text { [13] (section 2, } \\
\text { Appendix B) }\end{array}$ & $\begin{array}{l}\text { - Confirm status by vendor } \\
\text { - See the ASME N-stamp list and discussion in Reference } 13 \\
\text { Willingness and speed of vendors in obtaining nuclear } \\
\text { qualification is highly dependent on the future market they see for } \\
\text { HTGRs } \\
\text { - In order to ensure that the NGNP plant can be built without } \\
\text { schedule delays due to rework, all of the primary organizations, } \\
\text { including the NRC, utility, nuclear system vendors, component } \\
\text { suppliers, material suppliers, and EPC contractors, must ensure } \\
\text { that nuclear QA/QC programs are properly in place for all phases } \\
\text { of the project, starting with design and fabrication. For the NGNP } \\
\text { project particular focus is required for HTGR-specific vendors that } \\
\text { do not have previous nuclear QA/QC experience. Specifically, a } \\
\text { nuclear graphite QA/QC code and accreditation program needs } \\
\text { to be developed such that nuclear graphite QA/QC programs can } \\
\text { be certified. The NGNP project should coordinate with graphite } \\
\text { vendors and ASME / National Board to ensure that such } \\
\text { programs will be in place in time for NGNP deployment. } \\
\text { - High investment required re prospects for future business } \\
\text { - Go with commercial dedication for "one-of" suppliers (circulator, } \\
\text { SG) }\end{array}$ \\
\hline
\end{tabular}




\begin{tabular}{|c|c|c|c|c|c|c|c|c|c|}
\hline & $\begin{array}{c}\text { Infrastructure Need } \\
\text { [Note where "HTGR } \\
\text { Specific"] }\end{array}$ & $\begin{array}{c}\text { Supplierl } \\
\text { Company } \\
\text { Capabilities }\end{array}$ & $\begin{array}{l}\text { Current } \\
\text { Capacity }\end{array}$ & $\begin{array}{l}\text { Readiness for } \\
\text { NGNP }\end{array}$ & $\begin{array}{l}\text { Technology } \\
\text { Development } \\
\text { Needs }\end{array}$ & $\begin{array}{l}\text { Notes (Lead Time, } \\
\text { etc.) }\end{array}$ & Supplier Contact & $\begin{array}{l}\text { Document } \\
\text { References }\end{array}$ & $\begin{array}{l}\text { Comments / Recommendations / etc. } \\
\text { Expansion Capability / Plans }\end{array}$ \\
\hline & & & & & & & & & See the write-up in Section 4.5. \\
\hline 14. & Transportation & $\begin{array}{l}\text { Mammoet, } \\
\text { BiggE, among } \\
\text { others }\end{array}$ & $\begin{array}{l}\text { A land route is } \\
\text { the only possible } \\
\text { option to INL as } \\
\text { there are no } \\
\text { navigable } \\
\text { waterways close } \\
\text { to the site. Rail } \\
\text { shipment of the } \\
\text { assembled } \\
\text { vessel would not } \\
\text { be possible } \\
\text { because of the } \\
\text { size (primarily } \\
\text { the height and } \\
\text { width of the } \\
\text { load) and the } \\
\text { weight. A site } \\
\text { with barge } \\
\text { access would be } \\
\text { significantly less } \\
\text { constraining } \\
\text { from a } \\
\text { transportation } \\
\text { viewpoint. }\end{array}$ & A & None & $\begin{array}{l}\text { By truck, significant } \\
\text { upgrades will be } \\
\text { needed to be made } \\
\text { to bridges and } \\
\text { roads. Obtaining } \\
\text { state and local } \\
\text { permits and buy-in } \\
\text { could take years. } \\
\text { Infrastructure } \\
\text { upgrades will also } \\
\text { require lead time } \\
\text { and longer } \\
\text { transportation time. } \\
\text { A site with barge } \\
\text { access would likely } \\
\text { shorten the lead } \\
\text { time significantly } \\
\text { (although the barge } \\
\text { portion of the } \\
\text { transport could face } \\
\text { environmental } \\
\text { interveners, } \\
\text { depending on the } \\
\text { required sea route } \\
\text { and the time of } \\
\text { year). }\end{array}$ & $\begin{array}{l}\text { Mammoet USA } \\
\text { South, Inc. } \\
\text { Headquarters } \\
20525 \text { FM } 521 \\
\text { Rosharon, TX } 77583 \\
\text { Phone: (281) 369- } \\
2200\end{array}$ & [25] & $\begin{array}{l}\text { - For FOAK consider welded rolled plate fabrication for RPV } \\
\text { because transportation constraints to INL site may force the RPV } \\
\text { to be shipped partially assembled to INL and then assembled on } \\
\text { site. } \\
\text { Other than a fully assembled RPV, a core barrel could be the } \\
\text { limiting component as it must be shipped assembled in a } \\
\text { specially designed skid. } \\
\text { For Nth of kind, the site is assumed to be US Gulf Coast with } \\
\text { barge access, which would ease the transportation constraints } \\
\text { considerably and allow for forged rings fabrication and larger } \\
\text { modules }\end{array}$ \\
\hline 15. & $\begin{array}{l}\text { Ceramic Materials (to } \\
\text { be specified) }\end{array}$ & [TBD] & & B & [TBD] & & & [22] & $\begin{array}{l}\text { No materials qualification, joining (ceramic to ceramic, ceramic to } \\
\text { metal) or ASME Code work is being pursued at this time. } \\
\text { A Materials Qualification Plan for ceramic insulation is to be } \\
\text { developed, dependent on design } \\
\text { More details in Reference } 17 .\end{array}$ \\
\hline 16. & $\begin{array}{l}\text { Metallic Materials } \\
\text { (High temperature, } \\
\text { such as } 800 \mathrm{H}, 617 \text { ) }\end{array}$ & $\begin{array}{l}\text { ATI } \\
\text { Haynes } \\
\text { International } \\
\text { Special Metals } \\
\text { VDM } \\
\end{array}$ & $\begin{array}{l}\text { Sufficient } \\
\text { available }\end{array}$ & A & $\begin{array}{l}\text { ASME Code } \\
\text { activities and } \\
\text { compilation of } \\
\text { supporting data are } \\
\text { on-going }\end{array}$ & & & [22] & $\begin{array}{l}800 \mathrm{H} \text { is currently in the process of being raised } 100^{\circ} \mathrm{C}\left(860^{\circ} \mathrm{C}\right) .617 \\
\text { is in the process of being raised to } 950^{\circ} \mathrm{C} \text {. } \\
\text { More details in Reference } 17 .\end{array}$ \\
\hline $16 a$. & Hastelloy X/XR & $\begin{array}{l}\text { Alloy } X \text { could be } \\
\text { supplied by the } \\
\text { above vendors; } \\
\text { however, } X R \text { is } \\
\text { not available } \\
\text { from any of }\end{array}$ & & & & & & & 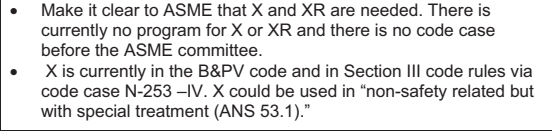 \\
\hline
\end{tabular}




\begin{tabular}{|c|c|c|c|c|c|c|c|c|c|}
\hline & $\begin{array}{l}\text { Infrastructure Need } \\
\text { [Note where "HTGR } \\
\text { Specific"] }\end{array}$ & $\begin{array}{l}\text { Supplier/ } \\
\text { Company } \\
\text { Capabilities }\end{array}$ & $\begin{array}{l}\text { Current } \\
\text { Capacity }\end{array}$ & $\begin{array}{l}\text { Readiness for } \\
\text { NGNP }\end{array}$ & $\begin{array}{l}\text { Technology } \\
\text { Development } \\
\text { Needs }\end{array}$ & $\begin{array}{l}\text { Notes (Lead Time, } \\
\text { etc.) }\end{array}$ & Supplier Contact & $\begin{array}{l}\text { Document } \\
\text { References }\end{array}$ & $\begin{array}{l}\text { Comments / Recommendations / etc. } \\
\text { Expansion Capability / Plans }\end{array}$ \\
\hline & & these suppliers. & & & & & & & $\begin{array}{l}\text { Note that XR would be considered a new material in regards to } \\
\text { ASME Code qualification. There is no US supplier for this } \\
\text { material. }\end{array}$ \\
\hline 17. & $\begin{array}{l}\text { Composite Materials } \\
\text { (in Core Structures) }\end{array}$ & SGL and others & $\begin{array}{l}\text { Sufficient } \\
\text { available }\end{array}$ & A & No & $\begin{array}{l}\text { Not NQA-1 for large } \\
\text { supplies }\end{array}$ & $\begin{array}{l}\text { Mr. Melin, } \\
\text { Segri }\end{array}$ & [7], [17] & $\begin{array}{l}\text { At present there is no applicable ASME Code for composites } \\
\text { A Materials Qualification Plan will need to be developed for specific } \\
\text { materials, dependent on design and application } \\
\text { More details in Reference } 17 .\end{array}$ \\
\hline 18. & Coatings (Metallic) & & & & & & & & (Later; design specific) \\
\hline 19. & $\begin{array}{l}\text { Graphite raw material } \\
\text { (reflector blocks, fuel } \\
\text { blocks, pebbles, } \\
\text { carbon insulation, } \\
\text { etc.) } \\
\text { [HTGR Specific] }\end{array}$ & $\begin{array}{l}\text { SGL Carbon } \\
\text { Toyo-Tanso }\end{array}$ & $\begin{array}{l}\text { Sufficient } \\
\text { available }\end{array}$ & A & No & $\begin{array}{l}5 \text { Years } \\
\text { Not NQA-1 for large } \\
\text { supplies }\end{array}$ & $\begin{array}{l}\text { Mr. Melin, } \\
\text { Segri }\end{array}$ & [17] & $\begin{array}{l}\text { The major issue for NGNP is the introduction of the ASME Section III, } \\
\text { Division } 5 \text { Code for the construction of Graphite Core Components. } \\
\text { Manufacturing capacity is not an issue. A typical graphite plant } \\
\text { producing specialty graphite can manufacture between 12,000- } \\
20,000 \text { tonnes of graphite per year (Electrode graphite plants produce } \\
\text { higher volumes). A single reactor will require less than } 2,000 \text { tonnes. } \\
\text { Even considering the demand for multiple reactors in a year, material } \\
\text { manufacture should not be a bottleneck. } \\
\text { See write-up in Section } 4.6 \\
\text { More details in Reference } 17 \text {. }\end{array}$ \\
\hline 20. & $\begin{array}{l}\text { High Temperature } \\
\text { Insulation (not core } \\
\text { structures) }\end{array}$ & $\begin{array}{l}\text { Various } \\
\text { Industrial } \\
\text { suppliers }\end{array}$ & $\begin{array}{l}\text { Should be } \\
\text { sufficient, not } \\
\text { large quantities } \\
\text { required }\end{array}$ & B & $\begin{array}{l}\text { High temperature } \\
\text { Insulation material } \\
\left(\mathrm{AL}_{2} \mathrm{O}_{3} \& \mathrm{SiO}_{2}\right. \\
\text { Ceramic Fibers) is } \\
\text { commercially } \\
\text { available. } \\
\text { Development } \\
\text { necessary to } \\
\text { integrate Ceramic } \\
\text { Fibers into a } \\
\text { successful } \\
\text { insulation design. } \\
\text { Component Test } \\
\text { Facility required for } \\
\text { testing. }\end{array}$ & $\begin{array}{l}\text { Successful } \\
\text { development of } \\
\text { integrated design } \approx \\
3 \text { years (including } \\
\text { testing) }\end{array}$ & $\mathrm{N} / \mathrm{A}$ & [16] & $\begin{array}{l}\text { Current design solutions sufficient for short/medium term but will } \\
\text { probably not survive } 60 \text { years lifetime requirement. }\end{array}$ \\
\hline 21. & $\begin{array}{l}\text { 1 \& C Sensors (High } \\
\text { Temperature, He, } P \text {, } \\
\text { flow, flux) } \\
\text { [HTGR Specific] }\end{array}$ & $\begin{array}{l}\text { Numerous } \\
\text { through } \\
\text { Westinghouse } \\
\text { Nuclear } \\
\text { Automation }\end{array}$ & $\begin{array}{l}\text { Capacity } \\
\text { currently } \\
\text { exceeds need } \\
\text { but may vary } \\
\text { depending on }\end{array}$ & B & [TBD] & $4-6$ years & $\begin{array}{l}\text { Westinghouse } \\
\text { Nuclear Automation }\end{array}$ & & $\begin{array}{l}\text { Requirements must be developed and equipment designed, } \\
\text { manufactured and qualified. } \\
\text { Environmental qualification in an HTGR environment will be } \\
\text { necessary }\end{array}$ \\
\hline
\end{tabular}




\begin{tabular}{|c|c|c|c|c|c|c|c|c|}
\hline $\begin{array}{c}\text { Infrastructure Need } \\
\text { [Note where "HTGR } \\
\text { Specific"] }\end{array}$ & $\begin{array}{c}\text { Supplierl } \\
\text { Company } \\
\text { Capabilities }\end{array}$ & $\begin{array}{l}\text { Current } \\
\text { Capacity }\end{array}$ & $\begin{array}{l}\text { Readiness for } \\
\text { NGNP }\end{array}$ & $\begin{array}{l}\text { Technology } \\
\text { Development } \\
\text { Needs }\end{array}$ & $\begin{array}{l}\text { Notes (Lead Time, } \\
\text { etc.) }\end{array}$ & Supplier Contact & $\begin{array}{l}\text { Document } \\
\text { References }\end{array}$ & $\begin{array}{l}\text { Comments / Recommendations / etc. } \\
\text { Expansion Capability / Plans }\end{array}$ \\
\hline & & $\begin{array}{l}\text { demand from } \\
\text { other projects }\end{array}$ & & & & & & See write-up in Section 4.7. \\
\hline $\begin{array}{l}\text { ISI Equipment } \\
\text { [HTGR Specific] }\end{array}$ & $\begin{array}{l}\text { WesDyne } \\
\text { (Westinghouse } \\
\text { subsidiary) }\end{array}$ & $\begin{array}{l}\text { Capacity } \\
\text { currently } \\
\text { exceeds need } \\
\text { but may vary } \\
\text { depending on } \\
\text { demand from } \\
\text { other projects }\end{array}$ & B & $\begin{array}{l}\text { Design of } \\
\text { equipment for } \\
\text { NGNP service is } \\
\text { required }\end{array}$ & $4-6$ years & $\begin{array}{l}\text { Westinghouse } \\
\text { Nuclear Automation }\end{array}$ & & $\begin{array}{l}\text { Requirements must be developed and equipment designed, } \\
\text { manufactured and qualified. }\end{array}$ \\
\hline $\begin{array}{l}\text { RCCS } \\
\text { [HTGR Specific] }\end{array}$ & [to be designed] & & B & Yes, testing & & & & Need a design, followed by testing as required \\
\hline $\begin{array}{l}\text { Duct Liner / Hot Gas } \\
\text { Duct } \\
\text { [HTGR Specific] }\end{array}$ & $\begin{array}{l}\text { No supplier, } \\
\text { must be } \\
\text { developed: } \\
\text { Technip } \\
\text { (currently BHR } \\
\text { Piping Systems) } \\
\text { have metallic } \\
\text { liner experience. } \\
\text { WESA has } \\
\text { limited } \\
\text { development } \\
\text { experience. }\end{array}$ & $\begin{array}{l}\text { Specially } \\
\text { designed and } \\
\text { manufactured } \\
\text { component. } \\
\text { Life and } \\
\text { temperature } \\
\text { limits with } \\
\text { metallic liner. } \\
800 \mathrm{H}: \mathrm{T} \leq \\
750^{\circ} \mathrm{C} \text {, } \\
\text { Hastelloy } \mathrm{X} \text { : } \\
750^{\circ} \mathrm{C}-850^{\circ} \mathrm{C} \\
\text { Life }<6 \text { yrs. } \\
\text { Ceramic } \\
\text { composite for } \mathrm{T} \\
\geq 900^{\circ} \mathrm{C} \text {. Gas } \\
\text { duct with } \\
\text { Ceramic liner } \\
\text { must be } \\
\text { developed. }\end{array}$ & C & $\begin{array}{l}\text { Technology for } \\
750^{\circ} \mathrm{C} \text { (metallic } \\
\text { liner) confirmed. } \\
\text { For higher temp. } \\
\left(950^{\circ} \mathrm{C} \text { ) new }\right. \\
\text { technology needs to } \\
\text { be developed. High } \\
\text { temperature, high } \\
\text { flow test loop } \\
\text { required to qualify } \\
\text { composite } \\
\text { materials. }\end{array}$ & $\begin{array}{l}\text { Estimate } 5 \text { years } \\
\text { required to develop, } \\
\text { test } \& \text { qualify high } \\
\text { temperature }(\geq \\
\left.750^{\circ} \mathrm{C}\right) \text { gas. }\end{array}$ & None & {$[3],[4],[13]$} & $\begin{array}{l}\text { High temperatures and high flow velocities a problem (vibration). } \\
\text { WE-SA have designed, built and tested a prototype gas duct for use } \\
\text { in the HTF. } \\
\text { Prototype not tested for high flow velocities. }\end{array}$ \\
\hline $\begin{array}{l}\text { Skilled Labor Force } \\
\text { (manufacturing and } \\
\text { construction) } \\
\text { [competition from } \\
\text { LWRs] }\end{array}$ & $\begin{array}{l}\text { AFL-CIO, US } \\
\text { Department of } \\
\text { Labor, } \\
\text { Nuclear } \\
\text { Fabrication } \\
\text { Consortium } \\
\text { (Administered } \\
\text { by Edison } \\
\text { Welding } \\
\text { Institute) }\end{array}$ & $\begin{array}{l}\text { Sufficient } \\
\text { capacity at the } \\
\text { moment but } \\
\text { shortages could } \\
\text { come if a large } \\
\text { number of LWR } \\
\text { domestic units } \\
\text { are under } \\
\text { construction } \\
\text { simultaneous-ly }\end{array}$ & B & None & $\begin{array}{l}\text { Construction } \\
\text { apprenticeship } \\
\text { programs take } 3 \text { to } \\
5 \text { years to complete }\end{array}$ & $\begin{array}{l}\text { AFL-CIO: Building } \\
\text { and Construction } \\
\text { Trades, George } \\
\text { Jones, 865-599-6245, } \\
\text { gjbctd@aol.com; US } \\
\text { Department of Labor, } \\
\text { Thomas Hooper, 202- } \\
\text { 693-3865, } \\
\text { hooper.thomas@dol.g } \\
\text { ov; Nate Ames }\end{array}$ & [13] (Section 6) & $\begin{array}{l}\text { - Qualified boilermakers, pipefitters, electricians, and ironworkers } \\
\text { are expected to be in short supply in local labor markets. For the } \\
\text { Idaho FOAK site in particular, the use of traveling workers from } \\
\text { other states/communities will be required } \\
\text { - If the NGNP is competing with more than } 8 \text { other LWR domestic } \\
\text { units under construction at the same time, the labor shortage will } \\
\text { be more severe; however, if there are less than } 8 \text { other units under } \\
\text { construction the labor shortage could be less severe }\end{array}$ \\
\hline
\end{tabular}




\begin{tabular}{|c|c|c|c|c|c|c|c|c|}
\hline $\begin{array}{l}\text { Infrastructure Need } \\
\text { [Note where "HTGR } \\
\text { Specific"] }\end{array}$ & $\begin{array}{l}\text { Supplierl } \\
\text { Company } \\
\text { Capabilities }\end{array}$ & $\begin{array}{l}\text { Current } \\
\text { Capacity }\end{array}$ & $\begin{array}{l}\text { Readiness for } \\
\quad \text { NGNP }\end{array}$ & $\begin{array}{l}\text { Technology } \\
\text { Development } \\
\text { Needs }\end{array}$ & $\begin{array}{l}\text { Notes (Lead Time, } \\
\text { etc.) }\end{array}$ & Supplier Contact & $\begin{array}{l}\text { Document } \\
\text { References }\end{array}$ & $\begin{array}{l}\text { Comments / Recommendations / etc. } \\
\text { Expansion Capability / Plans }\end{array}$ \\
\hline & & & & & & $\begin{array}{l}\text { NFC, Technical } \\
\text { Director } \\
\text { Mail: } 1250 \text { Arthur E. } \\
\text { Adams Dr., Columbus } \\
\text { OH } 43221 \\
\text { Phone: } 614.688 .5135 \\
\text { Cell: } 614.578 .7898 \\
\text { Email: } \\
\text { nate ames@ewi.org } \\
\text { Web: } \\
\text { nuclearfabrication.org } \\
\text { \& ewi.org } \\
\end{array}$ & & \\
\hline $\begin{array}{l}\text { Bellows (Hot duct } \\
\text { sections; RPV to } \\
\text { Cross Duct) } \\
\text { [HTGR Specific] }\end{array}$ & $\begin{array}{l}\text { Witzenmann } \\
\text { GmbH }\end{array}$ & $\begin{array}{l}\text { Capable } \\
\text { Dia: } \leq 3 \mathrm{~m} \\
\mathrm{P}: \leq 63 \mathrm{bar} \\
\mathrm{T} \leq 550 \mathrm{SS} \\
\mathrm{T} \leq 900 \text { Incoloy } \\
800 \mathrm{H}\end{array}$ & B & $\begin{array}{l}\text { Testing to confirm } \\
\text { high temperature } \\
\text { performance for } \\
\text { Alloy } 800 \mathrm{H}\end{array}$ & $\begin{array}{l}\text { High Quality, } \\
\text { Reproducible, } \\
\text { Lead time: } 3-6 \\
\text { Months }\end{array}$ & & [7], [16] & $\begin{array}{l}\text { High quality standard industrial designs. } \\
\text { Also supply to nuclear industry. } \\
\text { Well defined design. } \\
\text { Specification required. }\end{array}$ \\
\hline $\begin{array}{l}\text { Core Ceramic } \\
\text { Structures (Graphite } \\
\text { Blocks) } \\
\text { [HTGR Specific] }\end{array}$ & $\begin{array}{l}\text { SGL Carbon } \\
\text { Group }\end{array}$ & $\begin{array}{l}\text { Sufficient } \\
\text { available }\end{array}$ & A & Only radiation test & $\begin{array}{l}\text { Not NQA-1 for large } \\
\text { supplies }\end{array}$ & $\begin{array}{l}\text { Mr. Melin, } \\
\text { Sigri }\end{array}$ & Many & $\begin{array}{l}\text { ASME Codes being developed } \\
\text { Machining of the structures may be an issue. Machining is, however, } \\
\text { easier to scale than the manufacture of graphite feedstock. There } \\
\text { should be sufficient capacity to manufacture the structures for the } \\
\text { NGNP, and the capacity can be increased, as required. } \\
\text { See write-up in Section } 4.6 \text {. }\end{array}$ \\
\hline $\begin{array}{l}\text { Boronated Graphite } \\
\text { [HTGR Specific] }\end{array}$ & $\begin{array}{l}\text { Fangda Carbon } \\
\text { (China) }\end{array}$ & Limited & B & $\begin{array}{l}\text { Material would need } \\
\text { to be qualified }\end{array}$ & $\begin{array}{l}\text { Supplier has made } \\
\text { only one batch, for } \\
\text { HTR-10 }\end{array}$ & $\begin{array}{l}\text { www.fangdacarbon.c } \\
\text { om/en }\end{array}$ & & $\begin{array}{l}\text { The HTR-Module proposed three options: B4C Pins, B4C chunks } \\
\text { mixed into the graphite, or coated particles containing an absorber } \\
\text { (possibly Boron). } \\
\text { The Chinese material is made by mixing B4C homogenously with the } \\
\text { pitch and coke before baking. Homogenous mixing can be ensured. }\end{array}$ \\
\hline $\begin{array}{l}\text { Lateral Restraints \& } \\
\text { Tie Rods } \\
\text { [HTGR Specific] }\end{array}$ & SGL & $\begin{array}{l}\text { Sufficient } \\
\text { available }\end{array}$ & $\begin{array}{l}\text { A - Yes, not a } \\
\text { significant } \\
\text { problem. In } \\
\text { principle the } \\
\text { project could } \\
\text { now start }\end{array}$ & No & $\begin{array}{l}\text { Not NQA-1 for large } \\
\text { supplies }\end{array}$ & $\begin{array}{l}\text { Mr. Melin, } \\
\text { Sigri }\end{array}$ & Many & These are Composite material structures. \\
\hline $\begin{array}{l}\text { High Temperature } \\
\text { Concrete } \\
\text { [HTGR Specific] }\end{array}$ & Many Suppliers & Adequate & A & $\begin{array}{l}\text { Investigation of } \\
\text { techniques for } \\
\text { optimizing the } \\
\text { design of structural }\end{array}$ & $\begin{array}{l}\text { Available without a } \\
\text { long lead time }\end{array}$ & Many & [21] (Section 7) & $\begin{array}{l}\text { - If possible, minimize the structural concrete that is exposed to } \\
\text { long-term, steady-state temperatures in excess of the ASME } \\
\text { Boiler and Pressure Vessel Code limits } \\
\text { - With respect to material selection, the performance of the } \\
\text { concrete materials can be improved by: (1) minimizing the }\end{array}$ \\
\hline
\end{tabular}




\begin{tabular}{|c|c|c|c|c|c|c|c|c|c|}
\hline & $\begin{array}{l}\text { Infrastructure Need } \\
\text { [Note where "HTGR } \\
\text { Specific"] }\end{array}$ & $\begin{array}{l}\text { Supplierl } \\
\text { Company } \\
\text { Capabilities }\end{array}$ & $\begin{array}{l}\text { Current } \\
\text { Capacity }\end{array}$ & $\begin{array}{l}\text { Readiness for } \\
\quad \text { NGNP }\end{array}$ & $\begin{array}{l}\text { Technology } \\
\text { Development } \\
\text { Needs }\end{array}$ & $\begin{array}{l}\text { Notes (Lead Time, } \\
\text { etc.) }\end{array}$ & Supplier Contact & $\begin{array}{l}\text { Document } \\
\text { References }\end{array}$ & $\begin{array}{l}\text { Comments / Recommendations / etc. } \\
\text { Expansion Capability / Plans }\end{array}$ \\
\hline & & & & & $\begin{array}{l}\text { elements (i.e., } \\
\text { material selection } \\
\text { and design) to resist } \\
\text { the exposure to } \\
\text { temperatures higher } \\
\text { than the ASME } \\
\text { Boiler and Pressure } \\
\text { Vessel Code } \\
\text { (exposure to long- } \\
\text { term, steady-state } \\
\text { temperatures in } \\
\text { excess of } 65^{\circ} \mathrm{C} \\
\left(149^{\circ} \mathrm{F}\right)\end{array}$ & & & & $\begin{array}{l}\text { moisture content through aggregate gradation, placement } \\
\text { techniques, or use of extended-range water-reducing agents, (2) } \\
\text { utilizing aggregates having good thermal stability and low thermal } \\
\text { expansion characteristics such as lightweight or refractory } \\
\text { materials, (3) incorporating fibrous reinforcing materials such as } \\
\text { short, randomly oriented steel fibers to provide increased ductility, } \\
\text { dynamic strength, toughness, tensile strength, and improved } \\
\text { resistance to spalling, and (4) design the concrete mix for higher } \\
\text { strength so that any losses in properties resulting from long term } \\
\text { thermal exposure will still provide adequate safety margins }\end{array}$ \\
\hline 30. & $\begin{array}{l}\text { Rankine Cycle Steam } \\
\text { Plant }\end{array}$ & $\begin{array}{l}\text { Toshiba } \\
\text { Corporation, } \\
\text { Alstom, } \\
\text { Mitsubishi } \\
\text { Heavy } \\
\text { Industries, } \\
\text { Siemens Power } \\
\text { Generation, } \\
\text { among others }\end{array}$ & $\begin{array}{l}\text { Multiple } \\
\text { suppliers have } \\
\text { the capability to } \\
\text { supply steam } \\
\text { turbines and } \\
\text { associated } \\
\text { equipment for } \\
\text { supercritical } \\
\text { steam Rankine } \\
\text { cycles, which } \\
\text { are the best } \\
\text { available } \\
\text { technology }\end{array}$ & A & $\begin{array}{l}\text { None for a } \\
\text { supercritical } \\
\text { Rankine cycle, but } \\
\text { some technology } \\
\text { development in the } \\
\text { materials area } \\
\text { would be needed for } \\
\text { an ultra-supercritical } \\
\text { Rankine cycle, } \\
\text { which could provide } \\
\text { higher efficiency }\end{array}$ & $<3$ years & $\begin{array}{l}\text { Robert W. Beidler } \\
\text { Director - Business } \\
\text { Development } \\
\text { Toshiba International } \\
\text { Corporation } \\
\text { Power Systems } \\
\text { Division } \\
6 \text { Dickinson Drive } \\
\text { Building 300, Suite } 2 \\
\text { Chadds Ford, PA } \\
19317 \\
\text { BlackBerry/Cell: (610) } \\
636-2166 \\
\text { Fax: (610) 459-7846 } \\
\text { Email: } \\
\text { bobb@toshibatic- } \\
\text { pa.com }\end{array}$ & [26] & $\begin{array}{l}\text { Supercritical steam Rankine cycles for the NGNP operating } \\
\text { conditions are similar to those used in fossil plants. Although } \\
\text { adaptation for an HTGR has some limitations due to the absence } \\
\text { of radiant energy, cycles can still be designed using an HTGR } \\
\text { heat source }\end{array}$ \\
\hline 31. & $\begin{array}{l}\text { Burnup Measurement } \\
\text { (Gamma } \\
\text { spectrometer for } \\
\text { Pebble Bed) } \\
\text { [HTGR Specific] }\end{array}$ & $\begin{array}{l}\text { Thermo } \\
\text { Gamma-Metrics }\end{array}$ & $\begin{array}{l}\text { Standard } \\
\text { instruments } \\
\text { integrated into } \\
\text { PBMR } \\
\text { configuration }\end{array}$ & A & $\begin{array}{l}\text { System was } \\
\text { developed for } \\
\text { PBMR. May be } \\
\text { necessary to } \\
\text { develop a new } \\
\text { system for NGNP. }\end{array}$ & $\begin{array}{l}\text { Build to order. } \\
\text { High Quality, } \\
\text { Reproducible. } \\
\text { Lead time: } \approx 1 \text { Year }\end{array}$ & $\begin{array}{l}57788 \text { Pacific Center } \\
\text { Blvd. San Diego, CA } \\
92121\end{array}$ & Protected by IP & $\begin{array}{l}\text { Spectroscopic Instrument. } \\
\text { See BUMS write-up in Section } 4.8 \text {. }\end{array}$ \\
\hline 32. & Helium & $\begin{array}{l}\text { - Air Products } \\
\text { for Helium } \\
\text { - WESA for } \\
\text { Helium } \\
\text { Purification } \\
\text { System }\end{array}$ & $\begin{array}{l}\text { Can supply } \\
\text { required purity: } \\
99.999995 \% \\
\text { purity. } \\
\text { Sufficient supply } \\
\text { capability for } \\
\text { single reactor. } \\
\text { Multiple units } \\
\end{array}$ & A & & $\begin{array}{l}\text { Helium lead time: } 1- \\
3 \text { months } \\
\text { Helium Purification } \\
\text { System design, } \\
\text { build, commission: } \\
1 \text { year }\end{array}$ & $\begin{array}{l}\text { www.airproducts. com } \\
\text { Westinghouse SA } \\
\text { Highway Business } \\
\text { Park } \\
\text { Centurion, South } \\
\text { Africa }\end{array}$ & & $\begin{array}{l}\text { HTR Germany experience: It is economical/ practical to utilize plant } \\
\text { helium cleanup system (HPS) to purify helium. } \\
\text { Purification systems are commercially available. }\end{array}$ \\
\hline
\end{tabular}




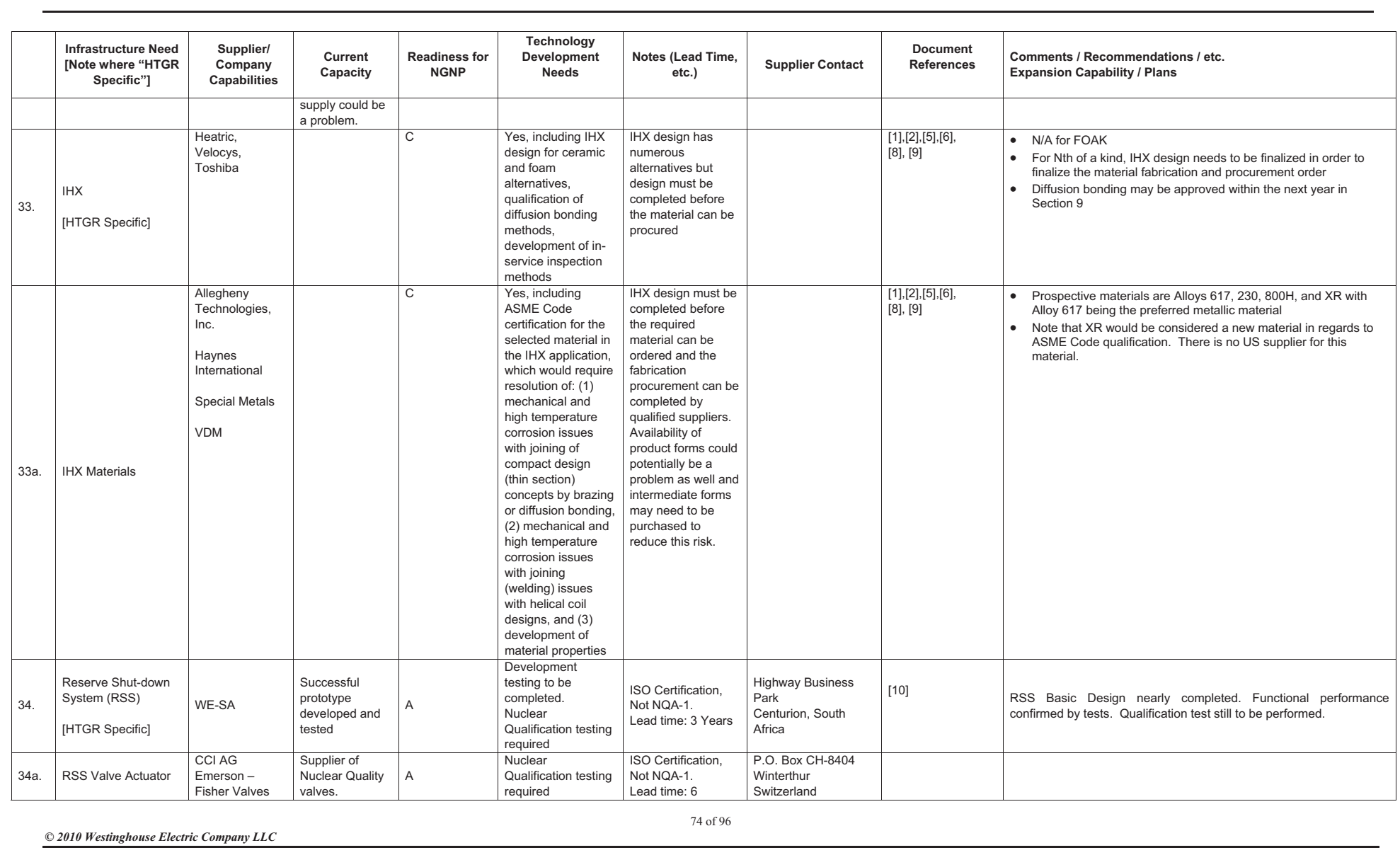




\begin{tabular}{|c|c|c|c|c|c|c|c|c|}
\hline $\begin{array}{c}\text { Infrastructure Need } \\
\text { [Note where "HTGR } \\
\text { Specific"] }\end{array}$ & $\begin{array}{l}\text { Supplier/ } \\
\text { Company } \\
\text { Capabilities }\end{array}$ & $\begin{array}{l}\text { Current } \\
\text { Capacity }\end{array}$ & $\begin{array}{l}\text { Readiness for } \\
\text { NGNP }\end{array}$ & $\begin{array}{l}\text { Technology } \\
\text { Development } \\
\text { Needs }\end{array}$ & $\begin{array}{l}\text { Notes (Lead Time, } \\
\text { etc.) }\end{array}$ & Supplier Contact & $\begin{array}{l}\text { Document } \\
\text { References }\end{array}$ & $\begin{array}{l}\text { Comments / Recommendations / etc. } \\
\text { Expansion Capability / Plans }\end{array}$ \\
\hline & & $\begin{array}{l}\text { Can supply } \\
\text { quantities } \\
\text { required. }\end{array}$ & & & Months & Fisher - US & & \\
\hline $\begin{array}{l}\text { Small Absorber } \\
\text { Spheres (SAS) } \\
\text { [HTGR Specific] }\end{array}$ & Schunk GmbH & $\begin{array}{l}\text { SAS } \\
\text { successfully } \\
\text { produced and } \\
\text { tested to WESA } \\
\text { Specification. } \\
\text { Can supply } \\
\text { quantities } \\
\text { required. }\end{array}$ & $A$ & $\begin{array}{l}\text { Nuclear } \\
\text { Qualification testing } \\
\text { required }\end{array}$ & $\begin{array}{l}\text { ISO Certification, } \\
\text { Not NQA-1. } \\
\text { Lead time: } 6 \\
\text { Months }\end{array}$ & $\begin{array}{l}\text { Rodheimer Straße } \\
59-61 \\
35452 \text { Heuchelheim } \\
\text { Germany }\end{array}$ & {$[10]$} & \\
\hline $\begin{array}{l}\text { Control Rod System } \\
\text { (Reactivity Control } \\
\text { System) } \\
\text { [HTGR Specific] }\end{array}$ & WE-SA & $\begin{array}{l}\text { Successful } \\
\text { prototype } \\
\text { developed and } \\
\text { tested. (ROT } \leq \\
750^{\circ} \mathrm{C} \text { ) } \\
\text { High Temp. } \\
\text { Composite } \\
\text { material not yet } \\
\text { developed. } \\
\text { (ROT } \leq 900^{\circ} \mathrm{C} \text { ) }\end{array}$ & $\begin{array}{l}\text { A }<750 C \\
\text { B }<900 C\end{array}$ & $\begin{array}{l}\text { Development } \\
\text { testing to be } \\
\text { completed (ROT } \leq \\
\left.750^{\circ} \mathrm{C}\right) \\
\text { New development } \\
\text { for high temperature } \\
\text { materials required. } \\
\text { (ROT } \leq 900^{\circ} \mathrm{C} \text { ) } \\
\text { Nuclear } \\
\text { Qualification testing } \\
\text { required }\end{array}$ & $\begin{array}{l}\text { ISO Certification } \\
\text { Not NQA-1 } \\
\text { Lead time: } 3 \text { years }\end{array}$ & $\begin{array}{l}\text { Highway Business } \\
\text { Park } \\
\text { Centurion, South } \\
\text { Africa }\end{array}$ & [10], [11] & $\begin{array}{l}\text { RCS Basic Design nearly completed for ROT } \leq 750^{\circ} \mathrm{C} \text {. Higher ROT } \\
\text { will require material qualification and redesign. Functional } \\
\text { performance confirmed by tests. Qualification test still to be } \\
\text { performed. }\end{array}$ \\
\hline $\begin{array}{l}\text { Control Rod System: } \\
\text { Stepper Motor }\end{array}$ & $\begin{array}{l}\text { Phytron- } \\
\text { Elektronic } \\
\text { GmbH, } \\
\text { Westinghouse } \\
\text { Electric } \\
\text { Company } \\
\text { (Newington) }\end{array}$ & $\begin{array}{l}\text { Successful } \\
\text { prototype exists. } \\
\text { Not yet nuclear } \\
\text { qualified }\end{array}$ & $A$ & $\begin{array}{l}\text { Nuclear } \\
\text { Qualification testing } \\
\text { required }\end{array}$ & $\begin{array}{l}\text { High Quality, } \\
\text { Reproducible, } \\
\text { Not NQA-1, } \\
\text { Lead time: } 1 \text { year }\end{array}$ & & & \\
\hline $\begin{array}{l}\text { Control Rod System: } \\
\text { Ceramic Bearings }\end{array}$ & Cerobear GmbH & $\begin{array}{l}\text { Proto-type dry } \\
\text { lubrication free } \\
\text { bearings } \\
\text { successfully } \\
\text { tested. Not yet } \\
\text { nuclear qualified }\end{array}$ & A & $\begin{array}{l}\text { Nuclear } \\
\text { Qualification testing } \\
\text { required }\end{array}$ & $\begin{array}{l}\text { High Quality, } \\
\text { Reproducible, } \\
\text { Not NQA-1, } \\
\text { Lead time: } 6 \\
\text { Months }\end{array}$ & $\begin{array}{l}\text { Kaiserstrasse } 100 \\
52134 \text { Herzogenrath } \\
\text { Germany }\end{array}$ & & \\
\hline $\begin{array}{l}\text { Control Rod System: } \\
\text { B } 4 \text { C Absorber } \\
\text { Material }\end{array}$ & $\begin{array}{l}\text { Mudanjiang } \\
\text { Jingangzuan } \\
\text { Boron Carbide } \\
\text { Co. Ltd. } \\
\text { Ceradyne }\end{array}$ & $\begin{array}{l}\text { B4C material } \\
\text { successfully } \\
\text { produced and } \\
\text { tested to WESA } \\
\text { Specification }\end{array}$ & A & $\begin{array}{l}\text { Nuclear } \\
\text { Qualification testing } \\
\text { required }\end{array}$ & $\begin{array}{l}\text { High Quality } \\
\text { ISO Certification } \\
\text { GB/T5152-85 } \\
\text { FEPA, JIS } \\
\text { Lead time: } 6 \\
\text { Months }\end{array}$ & $\begin{array}{l}\text { Mudanjiang City, } \\
\text { China } \\
\text { Ceradyne, Inc. } \\
\text { William D. Long, } \\
\text { Director, Nuclear \& } \\
\text { Advanced Materials } \\
\text { Sales } \\
714-384-9410 \\
\text { (direct), 714-276- }\end{array}$ & & \\
\hline
\end{tabular}




\begin{tabular}{|c|c|c|c|c|c|c|c|c|}
\hline $\begin{array}{l}\text { Infrastructure Need } \\
\text { [Note where "HTGR } \\
\text { Specific"] }\end{array}$ & $\begin{array}{l}\text { Supplierl } \\
\text { Company } \\
\text { Capabilities }\end{array}$ & $\begin{array}{l}\text { Current } \\
\text { Capacity }\end{array}$ & $\begin{array}{l}\text { Readiness for } \\
\quad \text { NGNP }\end{array}$ & $\begin{array}{l}\text { Technology } \\
\text { Development } \\
\text { Needs }\end{array}$ & $\begin{array}{l}\text { Notes (Lead Time, } \\
\text { etc.) }\end{array}$ & Supplier Contact & $\begin{array}{l}\text { Document } \\
\text { References }\end{array}$ & $\begin{array}{l}\text { Comments / Recommendations / etc. } \\
\text { Expansion Capability / Plans }\end{array}$ \\
\hline & & & & & & $\begin{array}{l}4674 \text { (cell) } \\
\text { wlong@,ceradyne.co } \\
\frac{\mathrm{m}}{3169 \text { Red Hill }} \\
\text { Avenue, Costa Mesa, } \\
\text { CA } 92626\end{array}$ & & \\
\hline
\end{tabular}

Notes:

1. Assumption: NGNP FOAK sited at INL, Nth of a kind sited at USGC site with barge access

2. Focus on construction and start of operations

3. NQA-1 / Reproducibility to be discussed later for NOAK

4. See document References

5. This matrix for NGNP FOAK only

6. Assumption: 2021 startup

Categorization of Needs (Readiness for NGNP):

A. Not a Significant Problem: e.g., (High Temperature Concrete)

B. Obtainable with Advanced Planning: e.g., ( Large Forgings)
C. Significant Infrastructure and / or Technical Development Required: e.g., (Fuel Assemblies) 


\section{CONCLUSIONS AND RECOMMENDATIONS FOR NGNP}

Overall, the majority of the issues identified in this report can be addressed with advanced planning. Items specific to HTGR technology and the NGNP will provide some unique challenges; however, none seem insurmountable for the current NGNP timeframe if assigned sufficient priority and resources.

Primary conclusions and recommendations of this report include:

- Fuel: At the present time, there is no HTGR fuel supplier in the U.S. (or worldwide) that has the capability to produce $\mathrm{UO}_{2} / \mathrm{UCO}$ fuel particles or assemblies / pebbles on a large scale for NGNP.

- Steam Generator: Since the NGNP steam generator is a one-per-unit component (like the circulator) it is most likely that a single supplier will need to be qualified for NGNP, without the assurance of near term additional orders.

- Helium Circulator: An operating regime for the NGNP main circulator must be defined and the qualification of material characteristics in the defined environment must be started. Specific design evaluations must be made (such as the relative merits of dry gas seals versus the challenges of the submerged motor and electrical penetrations) and material aging benchmark testing must start as soon as possible.

- Nuclear Quality Assurance (QA) and Quality Control (QC): Overall the nuclear QA/QC programs are developed and available for use on an NGNP, even the items that are particular to HTGR technology and NGNP. The major exception is graphite, which still requires some code and program development on the part of ASME and the vendors. At least one graphite manufacturer needs to be qualified to produce graphite to the new ASME Boiler and pressure Vessel Code Section III Division 5. Because it is so critical to the project, the NGNP program should ensure that at least one graphite manufacturer receives authorization by ASME to complete this work.

- Large Forgings: The capability to supply the very large forgings required for the NGNP plant is available, particularly for the SA 508/533 material proposed for the FOAK plant. Because of stiff competition from other nuclear projects around the world, the tight capacity has led to very long lead times. Although expansions of this capacity could improve the situation, it is still advisable to plan far in advance and place an order within a few years to ensure delivery in time for NGNP plant construction. 
- Instrumentation and Controls (I\&C): Similar to LWRs, design and NRC approval of digital plant control systems will be time consuming. All I\&C used for the NGNP should be standard Nuclear Power Plant technology. Environmental Qualification (EQ) of some instrumentation may be required due to specific NGNP environmental conditions and requirements.

- High Temperature Materials: At present there is no applicable ASME code for ceramic materials, composites, or Hastelloy X/XR. A Materials Qualification Plan will need to be developed for specific materials, dependent on design and application. Material $\left(\mathrm{Al}_{2} \mathrm{O}_{3}\right.$ $\& \mathrm{SiO}_{2}$ ceramic fibers) for high temperature insulation is commercially available; however, development is necessary to integrate ceramic fibers into a successful insulation design (current design solutions sufficient for short/medium term but will probably not survive 60 years lifetime requirement).

- Helium Valves: Operating temperatures will be a deciding factor in how difficult it is to fabricate and qualify helium valves. High temperature gas reactor designs so far have elected to reduce the necessity of having valves at reactor outlet temperatures. With careful design selection the high temperature challenges on valves may be avoided.

- Skilled Labor: Qualified boilermakers, pipefitters, electricians, and ironworkers are expected to be in short supply in local labor markets. For the Idaho FOAK site in particular, the use of traveling workers from other states/communities will be required. If the NGNP is competing with more than 8 other LWR domestic units under construction at the same time, the labor shortage will be more severe; however, if there are less than 8 other units under construction the labor shortage could be less severe.

The recommended path forward for NGNP includes activities associated with early completion of critical design work, technology development, standards development, and testing and qualification of important items. Many essential activities cannot start until sufficient design work has been completed. Completing sufficient design work early in the process will allow time and resources to be focused on technology development in critical areas that can be identified as the design progresses. These include placing forgings orders, and development of the helium circulator, helium valves, and sensors in order to resolve technology issues. Important to technology development efforts is QA/QC program development and standard development, which includes testing and qualification. In order to ensure that the NGNP plant can be built without schedule delays due to rework, all of the primary organizations, including the NRC, utility, nuclear system vendors, component suppliers, material suppliers, and EPC contractors, must ensure that nuclear QA/QC programs are properly in place for all phases of the project, starting with design and fabrication, with particular focus on HTGR-specific vendors that do not have previous nuclear QA/QC experience. Specifically, a nuclear graphite QA/QC code and accreditation program needs to be developed such that nuclear graphite QA/QC 
programs can be certified. The NGNP project should coordinate with graphite vendors and ASME/National Board to ensure that such programs will be in place in time for NGNP deployment. The NGNP program should ensure that at least one supplier is authorized to supply graphite core components to the new ASME code Division 5 requirements.

The NGNP Fuel Qualification Program should be completed and subsequently a fuel fabrication facility should be qualified.

Critical areas include: steam generator testing and fabrication including bending and welding, testing of high temperature insulation for long life service, testing and environmental qualification of sensors, instrumentation, and controls, and testing and ASME code development of ceramic material, composites and Hastelloy X/XR. 


\section{REFERENCES}

1. General Atomics, RPV and IHX Pressure Vessel Alternatives Study Report, Document No. 911118, April 23, 2008.

2. General Atomics, NGNP IHX and Secondary Heat Transport Loop Alternatives Study, Document No. 911119, April 23, 2008.

3. General Atomics, NGNP Composites R\&D Technical Issues Study, Document No. 911125, October 13, 2008.

4. General Atomics, Effect of Reactor Outlet Helium Temperature on the Need for Composites in the NGNP, Document No. 911175, June 11, 2009.

5. AREVA NP Inc., NGNP with Hydrogen Production RPV and IHX Pressure Vessel Alternatives, Document No. 12-9076324-001, April 2008.

6. AREVA NP Inc., NGNP with Hydrogen Production IHX and Secondary Heat Transport Loop Alternatives, Document No. 12-9076325-001, April 2008.

7. Westinghouse Electric Company, LLC, NGNP Conceptual Design Study: Composites $R \& D$ Technical Issues, Document Number NGNP-NHS TI-COMP, INL/EXT-09-16542, October 2008.

8. R. E. Mizia, Next Generation Nuclear Plant Intermediate Heat Exchanger Acquisition Strategy, INL/EXT-08-14054, REV.0, April 2008.

9. R. E. Mizia, Next Generation Nuclear Plant Reactor Pressure Vessel Acquisition Strategy, INL/EXT-08-13951, REV.0, April 2008.

10. John W. Collins, Next Generation Nuclear Plant Project Development Roadmaps: The Technical Path Forward, INL/EXT-08-15148, January 2009.

11. John W. Collins, Next Generation Nuclear Plant Project Development Roadmaps: The Technical Path Forward for 750-800 ${ }^{\circ} \mathrm{C}$ ROT, INL/EXT-09-16598, August 2009.

12. "NGNP Fuel Qualification White Paper”, INL/EXT-10-18610, Rev. 0, July 2010.

13. MPR, DOE NP2010 Nuclear Power Plant Construction Infrastructure Assessment, MPR-2776, October 21, 2005. 
14. Idaho National Laboratory, NGNP-Creating Validated TRL and TDRMs for Critical Systems, Subsystems, and Components, INL/EXT-08-14842, September 2008.

15. Oak Ridge National Laboratory, NGNP Graphite Selection and Acquisition Strategy, ORNL/TM-2007/153, September 2007.

16. William R. Corwin, "U.S. Generation IV Reactor Integrated Materials Technology Program", Nuclear Engineering and Technology, Vol. 38, No. 7, October 2006.

17. Idaho National Laboratory, NGNP High Temperature Materials White Paper, INL/EXT09-17187, June 2010.

18. M. Andrew Rossouw, "Development of a Blower for the PBMR Environment - Reliable, Versatile and Maintenance-Free," D00000205, Proceedings of HTR2006, $3^{\text {rd }}$

International Topical Meeting on High Temperature Reactor Technology, Johannesburg, South Africa, October 1-4, 2006.

19. G.G. Jacobs, G.J.F Hammann, M.A. Rossouw, "Submerged Helium Blower Experience with Specific Reference to the Electromagnetic Bearing Behaviour on the PBMR Heluim Test Facility," HTR2008-58290, Proceedings of HTR2008, $4^{\text {th }}$ International Topical Meeting on High Temperature Reactor Technology, Washington, DC USA, September 28 - October 1, 2008.

20. John Crane, "Type 28 Compressor Seals, Dry-Running, Non-Contacting Gas Seals," S28AT/28EXP/Eng, <www.johncrane.com>, November 2009.

21. Oak Ridge National Laboratory, The Effect of Elevated Temperature on Concrete Materials and Structures - A Literature Review, NUREG/CR-6900, ORNL/TM2005/533, March 2006.

22. [Not used]

23. [Not used]

24. World Nuclear Association, "Heavy Manufacturing of Power Plants," September 2010, $<$ http://www.worldnuclear.org/info/inf122_heavy_manufacturing_of_power_plants.html>.

25. Bigge Power Constructors, "Nuclear Power Plant New Construction," Transportation Case Study, September 21, 2006.

26. Alstom, "MT Steam Turbine,” Technical Datasheet, 2009. 
27. ASTM D7219-08. "Standard Specification for Isotropic and Near-isotropic Nuclear." ASTM, 2008.

28. Nabliek H., Mitchell M. "Graphite and Ceramic Coated Particles for the HTR." 34th International Conference on Advanced Ceramics \& Composites (ICACC), Daytona Beach, Florida, 2010. 


\section{APPENDIX A. HELIUM TEST FACILITY PROCUREMENT EXPERIENCE AND LESSONS LEARNED}

\section{A.1 Introduction}

The objective of constructing the HTF in South Africa was to provide a high temperature and pressure helium environment within which products designed for application in the Pebble Bed Modular Reactor may be evaluated, characterized and qualified. The summary notes presented here are applicable to procurement activities related to the establishment of the testing facility and not necessarily to any of the components/units procured for testing purposes.

It should be noted that the HTF was conceived and constructed as a non-nuclear test facility. Procurement requirements aimed specifically for the acquisition of nuclear related commodities and services were therefore not relevant in this instance. Furthermore, cost and schedule considerations mandated that the design and procurement activities be focused on existing technologies currently available from the broader South African engineering and construction industry.

Section A.3 provides a tabular summary per commodity and/or service of procurement experiences through the execution of the HTF procurement project. There were, however, also a number of common themes which are highlighted in the following general comment sections.

\section{A.2 General Comments}

\section{A.2.1 Design Maturity}

Integration of the HTF design and construction activities within the broader PBMR roll out plan (as it existed at that stage) required that the actual procurement and construction project be initiated well before all the design activities for schedule critical items was complete. In particular, this was true for most pressure vessels, piping and components as well as the installation of the mechanicals. The resulting multiple amendments to the original procurement specifications contributed in a major way to the experienced over-runs in cost and schedule as well as the complexity of supplier contract administration. Certainly in terms of the mechanical installation contract a case can be made that the cost of delaying initiation of the on-site installation activities until the piping design reached a more mature stage would have been less than the cost incurred from contract completion delays caused by insufficient specifications. 


\section{A.2.2 Pressure Vessel Inspection and Certification}

During the contracting phase with PBMR the understanding was that pressure vessel inspection and certification would be governed by the relevant regulations of the Occupational Health and Safety Act (Act 85 of 1993 as amended). The supply of pressure vessels as well as other pressure containing units was then contracted with suppliers on this basis. However, PBMR as the user of such equipment had additional requirements on inspection and certification which were essentially not visible, or misunderstood in the original HTF contracting process. This difference in interpretation of requirements resulted in substantial tension between the contracting parties. In some cases acceptance of completed units experienced major delays whilst the acceptance documentation was being argued. In certain instances it required effort at the executive level to reach an agreement between the main contracting parties. Prior understanding and agreement on acceptance criteria proved to be critical in this specific case.

\section{A.2.3 Credibility of Material Test Certificates}

A common theme noted across most procurement activities that required the delivery of material test certificates was the inadequate quality of certificates that were accepted by the suppliers from their material suppliers. The statement of conformance seldom conformed to the requirements of ASME II material specifications. Many out-of-specification chemical and mechanical test results were found on released material certificates. On enquiry some suppliers were observed to merely correct such deviations on the certificate without any reference to substantiating data. This practice eroded the credibility of certificates to the point where it was considered prudent to have all material tested prior to acceptance in order to verify certified figures. In fairness, it needs to be added that once pointed out, most suppliers to the HTF accepted credible certification as an issue and have enhanced their Quality Management Systems by including processes to independently verify the adequacy of material certificates provided by material suppliers. 


\section{A.3 Summary of Procurement Experience per HTF Service/Commodity}

\begin{tabular}{|c|c|c|c|c|c|}
\hline $\begin{array}{l}\text { Service/ } \\
\text { Commodity }\end{array}$ & $\begin{array}{l}\text { Supply: } \\
\text { Local (SA)/ } \\
\text { Import }\end{array}$ & $\begin{array}{c}\text { Quality } \\
\text { Requirements }\end{array}$ & $\begin{array}{l}\text { Lead Time } \\
\text { Required }\end{array}$ & $\begin{array}{l}\text { Supplier } \\
\text { Capability }\end{array}$ & $\begin{array}{c}\text { Comments on Procurement } \\
\text { Experience }\end{array}$ \\
\hline $\begin{array}{l}\text { Civil \& } \\
\text { Structural }\end{array}$ & Local & $\begin{array}{l}\text { As per current } \\
\text { Building } \\
\text { Regulations } \\
\text { and OHS Act. }\end{array}$ & $\begin{array}{l}2 \text { Months } \\
\text { for civil and } \\
\text { structural } \\
\text { design. } \\
6 \text { Months } \\
\text { for } \\
\text { construction. }\end{array}$ & $\begin{array}{l}\text { Well } \\
\text { established. }\end{array}$ & $\begin{array}{l}\text { Subcontracted to a reputable } \\
\text { subcontractor. }\end{array}$ \\
\hline $\begin{array}{l}\text { Building } \\
\text { Services: } \\
\text { Elevator, } \\
\text { Fire Protection, } \\
\text { HVAC }\end{array}$ & Local & $\begin{array}{l}\text { As per current } \\
\text { National } \\
\text { Building } \\
\text { Regulations, } \\
\text { local authority } \\
\text { bylaws and } \\
\text { OHS Act. } \\
\text { ISO 9001 } \\
\text { compliant. }\end{array}$ & $\begin{array}{l}\text { Elevator: } 6 \\
\text { Months } \\
\text { Fire } \\
\text { Protection: } 1 \\
\text { Month } \\
\text { HVAC: On } \\
\text { demand. }\end{array}$ & $\begin{array}{l}\text { Well } \\
\text { established. }\end{array}$ & Industrial units installed. \\
\hline $\begin{array}{l}\text { Air Cooled } \\
\text { Heat } \\
\text { Exchangers }\end{array}$ & Local & $\begin{array}{l}\text { ASME VIII } \\
\text { Div } 1\end{array}$ & 3 Months & $\begin{array}{l}\text { Well } \\
\text { established. }\end{array}$ & $\begin{array}{l}\text { Although manufactured in } \\
\text { accordance with ASME VIII } \\
\text { requirements, U-stamp was not } \\
\text { required. }\end{array}$ \\
\hline $\begin{array}{l}\text { Shell \& Tube } \\
\text { Heat } \\
\text { Exchangers }\end{array}$ & Local & $\begin{array}{l}\text { ASME VIII } \\
\text { Div } 1\end{array}$ & 3 Months & $\begin{array}{l}\text { Well } \\
\text { established. }\end{array}$ & $\begin{array}{l}\text { Although manufactured in } \\
\text { accordance with ASME VIII } \\
\text { requirements, U-stamp was not } \\
\text { required. }\end{array}$ \\
\hline $\begin{array}{l}\text { Gas Analyzer } \\
\text { System }\end{array}$ & Local & $\begin{array}{l}\text { Instrument } \\
\text { OEM } \\
\text { calibration } \\
\text { certificates } \\
\text { referenced to a } \\
\text { national } \\
\text { standard. } \\
\text { ISO } 9001 \\
\text { Compliant. }\end{array}$ & 6 Months & $\begin{array}{l}\text { Well } \\
\text { established. }\end{array}$ & Industrial units installed. \\
\hline $\begin{array}{l}\text { Encapsulated } \\
\text { Helium Blower }\end{array}$ & $\begin{array}{l}\text { Import } \\
\text { Main } \\
\text { contractor: } \\
\text { Howden UK } \\
\text { Ltd. } \\
\text { Bearing } \\
\text { subcontractor: } \\
\text { Waukesha } \\
\text { Bearings } \\
\text { Corp. }\end{array}$ & $\begin{array}{l}\text { ASME VIII } \\
\text { Div } 2 . \\
\text { ISO 9001 } \\
\text { compliant. }\end{array}$ & 12 Months & $\begin{array}{l}\text { First of a } \\
\text { kind } \\
\text { project. } \\
\text { Supplier } \\
\text { procedures } \\
\text { sufficient. }\end{array}$ & $\begin{array}{l}\text { End use undertaking required. } \\
\text { Reliability of magnetic bearings } \\
\text { (specifically bearing control } \\
\text { system) proved to be } \\
\text { problematic (Quality of coil } \\
\text { manufacture). Initial and early } \\
\text { choice of magnetic bearing } \\
\text { supplier is a critical } \\
\text { consideration, as well as } \\
\text { inspections during component } \\
\text { manufacture. }\end{array}$ \\
\hline
\end{tabular}




\begin{tabular}{|c|c|c|c|c|c|}
\hline $\begin{array}{l}\text { Service/ } \\
\text { Commodity }\end{array}$ & $\begin{array}{l}\text { Supply: } \\
\text { Local (SA)/ } \\
\text { Import }\end{array}$ & $\begin{array}{c}\text { Quality } \\
\text { Requirements }\end{array}$ & $\begin{array}{l}\text { Lead Time } \\
\text { Required }\end{array}$ & $\begin{array}{c}\text { Supplier } \\
\text { Capability }\end{array}$ & $\begin{array}{c}\text { Comments on Procurement } \\
\text { Experience }\end{array}$ \\
\hline $\begin{array}{l}\text { Control \& } \\
\text { Instrumentation } \\
\text { Components }\end{array}$ & $\begin{array}{l}\text { Imported } \\
\text { instruments } \\
\text { procured from } \\
\text { local } \\
\text { suppliers. }\end{array}$ & $\begin{array}{l}\text { Instrument } \\
\text { OEM } \\
\text { calibration } \\
\text { certificates } \\
\text { referenced to a } \\
\text { national } \\
\text { standard. }\end{array}$ & $\begin{array}{l}1 \text { to } 3 \\
\text { Months } \\
\text { dependent } \\
\text { on } \\
\text { instrument } \\
\text { type. }\end{array}$ & $\begin{array}{l}\text { Well } \\
\text { established. }\end{array}$ & Industrial units installed. \\
\hline $\begin{array}{l}\text { Control \& } \\
\text { Instrumentation } \\
\text { Installation }\end{array}$ & Local & $\begin{array}{l}\text { ISO } 9001 \\
\text { Compliant }\end{array}$ & 1 Month & $\begin{array}{l}\text { Well } \\
\text { established. }\end{array}$ & $\begin{array}{l}\text { Installation as per petro- } \\
\text { chemical industry standards. }\end{array}$ \\
\hline $\begin{array}{l}\text { Helium } \\
\text { Compressor }\end{array}$ & Import & $\begin{array}{l}\text { As per product } \\
\text { specification. }\end{array}$ & 12 Months & Established & $\begin{array}{l}\text { Due to cost considerations, a } \\
\text { commercial reciprocating } \\
\text { compressor was procured. A } \\
\text { number of reliability problems } \\
\text { were experienced during } \\
\text { operation. A more expensive } \\
\text { industrial type machine may } \\
\text { have been more appropriate. }\end{array}$ \\
\hline $\begin{array}{l}\text { Mechanical } \\
\text { Construction \& } \\
\text { Installation }\end{array}$ & Local & $\begin{array}{l}\text { ISO } 9001 \\
\text { Compliant }\end{array}$ & 6 Months & Established & $\begin{array}{l}\text { Method of contracting, EPC vs. } \\
\text { EPMC, needs to be carefully } \\
\text { considered. } \\
\text { Initiation of mechanical } \\
\text { construction prior to finalization } \\
\text { of some design activities } \\
\text { resulted in major cost and } \\
\text { schedule overruns. }\end{array}$ \\
\hline Scaffolding & Local & $\begin{array}{l}\text { ISO } 9001 \\
\text { Compliant. } \\
\text { OSH Act. }\end{array}$ & 1 Month & $\begin{array}{l}\text { Well } \\
\text { established. }\end{array}$ & $\begin{array}{l}\text { Supplier conversant with } \\
\text { requirements for petro-chemical } \\
\text { industry. }\end{array}$ \\
\hline Cooling Tower & Local & $\begin{array}{l}\text { ISO } 9001 \\
\text { Compliant. }\end{array}$ & 2 Months & $\begin{array}{l}\text { Well } \\
\text { established. }\end{array}$ & Industrial unit installed. \\
\hline $\begin{array}{l}\text { Electrical } \\
\text { Heaters }\end{array}$ & Local & $\begin{array}{l}\text { ISO } 9001 \\
\text { Compliant. }\end{array}$ & 1 Month & $\begin{array}{l}\text { Well } \\
\text { established. }\end{array}$ & $\begin{array}{l}\text { Unit design influenced the } \\
\text { reliability of delivered units. }\end{array}$ \\
\hline $\begin{array}{l}\text { Ribbed Sphere } \\
\text { Pipes (for fuel } \\
\text { spheres) }\end{array}$ & $\begin{array}{l}\text { Local: } \\
\text { Manufacturing } \\
\text { of ribbed } \\
\text { sphere pipes. } \\
\text { Import: } \\
\text { Induction } \\
\text { bending. }\end{array}$ & $\begin{array}{l}\text { As per product } \\
\text { specification. }\end{array}$ & 3 Months & Established. & $\begin{array}{l}\text { Contractor to perform induction } \\
\text { bending needs to be carefully } \\
\text { chosen. } \\
\text { Pipe joining required automated } \\
\text { orbital welding. } \\
\text { Maintaining dimensional } \\
\text { tolerance after bending is a } \\
\text { critical issue in sphere pipes. }\end{array}$ \\
\hline $\begin{array}{l}\text { Graphite } \\
\text { Components }\end{array}$ & Local & $\begin{array}{l}\text { As per product } \\
\text { specification. } \\
\text { ISO } 9001 \\
\text { Compliant. }\end{array}$ & 6 Months & Established. & $\begin{array}{l}\text { Components manufactured } \\
\text { from local electrode grade } \\
\text { material. }\end{array}$ \\
\hline
\end{tabular}




\begin{tabular}{|c|c|c|c|c|c|}
\hline $\begin{array}{l}\text { Service/ } \\
\text { Commodity }\end{array}$ & $\begin{array}{l}\text { Supply: } \\
\text { Local (SA)/ } \\
\text { Import }\end{array}$ & $\begin{array}{c}\text { Quality } \\
\text { Requirements }\end{array}$ & $\begin{array}{l}\text { Lead Time } \\
\text { Required }\end{array}$ & $\begin{array}{l}\text { Supplier } \\
\text { Capability }\end{array}$ & $\begin{array}{c}\text { Comments on Procurement } \\
\text { Experience }\end{array}$ \\
\hline $\begin{array}{l}\text { Insulation \& } \\
\text { Cladding }\end{array}$ & Local & $\begin{array}{l}\text { As per product } \\
\text { specification. } \\
\text { ISO } 9001 \\
\text { Compliant. }\end{array}$ & 2 Months & $\begin{array}{l}\text { Well } \\
\text { established. }\end{array}$ & $\begin{array}{l}\text { Supplier conversant with } \\
\text { requirements for petro-chemical } \\
\text { industry. } \\
\text { Insufficient cladding } \\
\text { specifications were a minor } \\
\text { issue during execution. }\end{array}$ \\
\hline Forgings & Import & $\begin{array}{l}\text { ASME } \\
\text { Section II. }\end{array}$ & 9 Months & $\begin{array}{l}\text { Well } \\
\text { established. }\end{array}$ & $\begin{array}{l}\text { Lead times dependent on } \\
\text { forging size. } \\
\text { Supplier ASME accredited. }\end{array}$ \\
\hline $\begin{array}{l}\text { Piping \& } \\
\text { Components }\end{array}$ & Local & $\begin{array}{l}\text { ASME } \\
\text { Section II. }\end{array}$ & 1-3 Months & $\begin{array}{l}\text { Well } \\
\text { established. }\end{array}$ & $\begin{array}{l}\text { Quality of supplied Material } \\
\text { Test Certificates needs to be } \\
\text { carefully scrutinized, } \\
\text { specifically for imported piping } \\
\text { components and fasteners. }\end{array}$ \\
\hline Recuperator & $\begin{array}{l}\text { Import } \\
\text { Vendor: } \\
\text { Heatric UK } \\
\end{array}$ & $\begin{array}{l}\text { ASME VIII } \\
\text { Div } 1\end{array}$ & 6 Months & $\begin{array}{l}\text { Well } \\
\text { established. }\end{array}$ & Delivered unit U-stamped. \\
\hline Valves & $\begin{array}{l}\text { Import } \\
\text { Vendors: } \\
\text { - Velan SAS } \\
\text { - Velan Inc. } \\
\text { - Segault } \\
\text { - Swagelok } \\
\text { - Hale } \\
\text { Hamilton } \\
\text { Valves } \\
\text { - Broady } \\
\text { Flow } \\
\text { Control } \\
\text { - Curtis } \\
\text { Wright } \\
\text { Flow } \\
\text { Control }\end{array}$ & $\begin{array}{l}\text { ASME } \\
\text { Section II. }\end{array}$ & 12 Months & $\begin{array}{l}\text { Well } \\
\text { established. }\end{array}$ & $\begin{array}{l}\text { Some units delivered with } \\
\text { RCCM material certification } \\
\text { instead of ASME II as specified. } \\
\text { Demonstrating equivalency } \\
\text { required additional effort. } \\
\text { Some units delivered with } \\
\text { inappropriate NDE reports. } \\
\text { Some units were packed for } \\
\text { delivery without a proper drying } \\
\text { cycle after acceptance testing, } \\
\text { thus requiring re-work by } \\
\text { supplier to remove rust. } \\
\text { Pressure safety valves required } \\
\text { End Use Undertaking. }\end{array}$ \\
\hline $\begin{array}{l}\text { Pressure } \\
\text { Bursting Discs }\end{array}$ & Import & ASME VIII & 3 Months & $\begin{array}{l}\text { Well } \\
\text { established. }\end{array}$ & $\begin{array}{l}\text { No procurement problems } \\
\text { experienced. }\end{array}$ \\
\hline
\end{tabular}




\begin{tabular}{|l|l|l|l|l|l|}
\hline $\begin{array}{c}\text { Service/ } \\
\text { Commodity }\end{array}$ & $\begin{array}{c}\text { Supply: } \\
\text { Local (SA)/ } \\
\text { Import }\end{array}$ & $\begin{array}{c}\text { Quality } \\
\text { Requirements }\end{array}$ & $\begin{array}{c}\text { Lead Time } \\
\text { Required }\end{array}$ & $\begin{array}{c}\text { Supplier } \\
\text { Capability }\end{array}$ & $\begin{array}{c}\text { Comments on Procurement } \\
\text { Experience }\end{array}$ \\
\hline $\begin{array}{l}\text { Pressure } \\
\text { Vessels }\end{array}$ & Local & $\begin{array}{l}\text { ASME VIII } \\
\text { Div 1 }\end{array}$ & 9 Months & $\begin{array}{l}\text { Well } \\
\text { established. }\end{array}$ & $\begin{array}{l}\text { Although manufactured in } \\
\text { accordance with ASME VIII } \\
\text { requirements, U-stamp was not } \\
\text { required. } \\
\text { Contractor compliance with } \\
\text { approved Quality Control Plans } \\
\text { proved to be problematic in } \\
\text { some instances. This resulted in } \\
\text { re-work with impact on } \\
\text { schedule and cost. }\end{array}$ \\
\hline $\begin{array}{l}\text { Electrical } \\
\text { Reticulation }\end{array}$ & Local & $\begin{array}{l}\text { As per current } \\
\text { Building } \\
\text { Regulations } \\
\text { and OHS Act. } \\
\text { ISO 9001 } \\
\text { compliant. }\end{array}$ & 4 Months & Well \\
established. & $\begin{array}{l}\text { Installation as per petro- } \\
\text { chemical industry standards. }\end{array}$ \\
& & & & \\
\end{tabular}




\section{APPENDIX B. SUPPLY CHAIN MANAGEMENT LESSONS LEARNED FROM GEN III+ REACTOR DEPLOYMENT}

Supply chain management lessons learned from deployment of Generation III+ reactors include the following.

- When negotiating the sale of a new reactor plant with a prospective customer, assume the approach, to the extent practical, that adoption of requirements unique to a particular customer is to be avoided.

- Avoid being locked in to use of a particular supplier's proprietary equipment design.

- To the extent practical, avoid ordering components and modules prior to completion of the equipment specification and, where applicable, the component design.

- Assure that the suppliers, even when qualified, fully understand and are staffed and trained to deal with the complexities, detail and volume associated with design, manufacture and transport of the components.

- Assure that the reactor plant prime contracting organization is staffed and trained to properly handle the large amount of document processing that will occur including document recording and tracking, document approval and document retention.

- Implement at an early point in the project a system to both identify risks to project quality, cost and schedule performance, and to also develop plans to eliminate or minimize the risk. 


\section{APPENDIX C. WESTINGHOUSE EXPERIENCE WITH HELIUM CIRCULATORS}

Historically Westinghouse has investigated Helium circulators for many applications, ranging from larger size "start-up" applications to smaller sized conditioning and solid matter transport circulators. Most of these systems were substantially more complex in operating profile than a main loop circulator as proposed for the NGNP, simply because they were expected to operate over a greater pressure range, and in some post-event or commissioning applications, with variable gas mixtures. This biased the design solution towards centrifugal circulars, for a number of reasons, including:

- Higher pressure ratios were required when operating at low pressure, but which could still be achieved in a single stage by a centrifugal design, hence avoiding complex multi-stage configurations.

- Many of these circulators did not operate continuously. This made Dry Gas Seal solutions, which have higher leakage rates when stationary, less attractive. Dry Gas systems also have more extensive support systems, which were less attractive in dispersed locations.

- Most of the circulators were of reasonably small size (relative to main circulators), which still yielded practical submerged-motor and reasonably sized impeller designs.

- Most circulators had post-event investment protection functions, which required very high reliability and an extra-ordinary wide operating range.

The combination of factors supported a centrifugal overhung impeller with a submerged motor, thus eliminating leakage and creating a motor cavity that could be kept cool, even when the circulating gas was near the vessel limits. However, none were as large as a potential main circulator for a NGNP could be. The circulator that was taken to practical application was a mere $100 \mathrm{~kW}$.

It was decided that one of the circulator concepts needed to be taken through a full design phase. The opportunity arose with the design of a Helium Test Facility for developing and qualifying HTGR components. It was recognized that the circulator needed for the test loop could be designed to be a near replica of some of the application circulators, and this would allow experience to be gained before the final application circulators were designed. As with so many engineering designs, all the components were in theory mature technologies, but the combining of the technologies still yields challenges.

Previous studies seemed to suggest that when it comes to circulators, it can be a "one size fits all". This is not quite true, and there are specific design conditions which may favor one solution above another. The question remains on what the proposed size of the circulator would be, and what circulator configurations are tolerable within the layout. Several different values are quoted in different studies, depending on the configuration. One of the key elements to consider is how 
the circulator will be maintained or replaced, since that may be a factor in deciding on a configuration. Some impeller configurations are also more tolerant to inflow vortexes and asymmetric flow, originating from the IHX (for example). These can be eliminated by the correct circulator inlet design, but it adds physical distance to the inlet that cannot always be tolerated. In such a case the impeller must simply tolerate the inconsistent inflow.

\section{Circulator Impeller Configuration}

The primary decision on the type of circulator is the functional mechanism, which is in turn determined by the volume of gas to be moved, and the resistance of the circuit. The aggressive environment of a HTGR typically favors a centrifugal impeller, so that the overhang between the motor and the impeller eliminates the need for a 'hot' bearing in the inlet duct, and an artificial 'cooler' environment can be created for the motor behind the impeller. This creates a configuration in which the really exposed items, other than the impeller, are stationary parts and thus not significantly stressed. The key component of this type of arrangement is the impeller temperature and stress.

However, centrifugal circulators have their disadvantages. As the volume flow increases the depth of the blade increases, placing more mass further away from the supporting bearing. As the pressure rise required increases, the impeller needs to increase its speed and its radial size; hence, the stress in the impeller increases and the efficiency of the impeller design reduces. This lowering in efficiency is partly due to the fact that as distances and size increase leakage effects become pronounced through rotor and bearing stiffness. This effect is accentuated by Automatic Magnetic Bearings (AMB), since they are naturally more flexible bearings. The consequence is that, considering no other layout factors, the design trends from Centrifugal impellers towards mixed flow and then axial flow (a "fan" in its most elementary form) as the specific speed increases ${ }^{1}$.
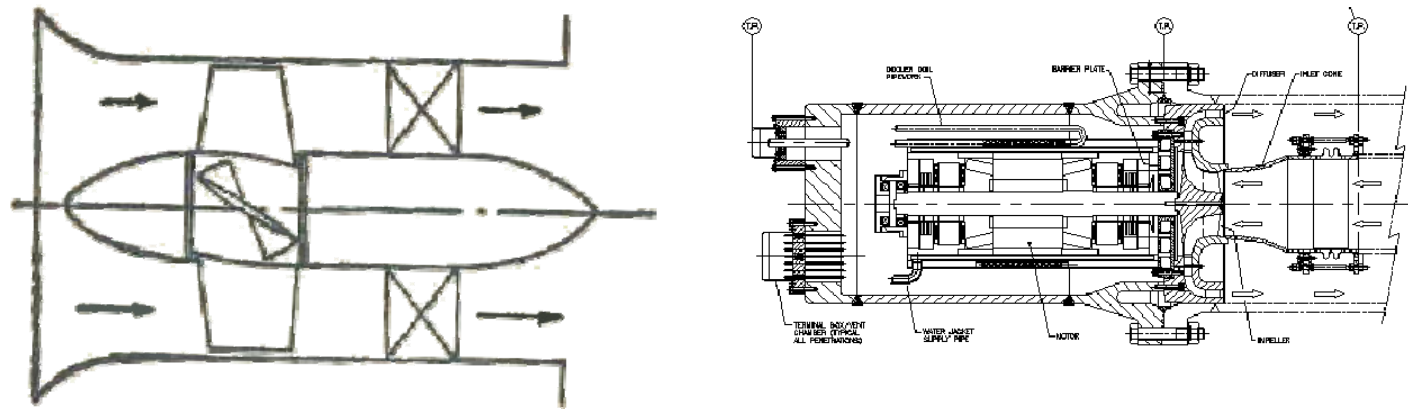

Figure C-1. A Fan Configuration (High Flow, low head) versus a Centrifugal Configuration (High Head at low flow)

${ }^{1}$ Specific speed $=$ Rotational Speed $*(\text { Volume flow })^{0.5} /(\text { Head rise })^{0.75}$ 
Figure C-1 above illustrates the two extremes in variation of the single-stage impeller configuration. To the left a high flow and low pressure rise supports a configuration in which the motor is surrounded by the main (hot) flow, while the configuration to the right turns the flow by $180^{\circ}$, using the impeller to shield the motor from the hot gas.

The thermal effects must also be considered in applications with very high temperatures. The dimensions of a centrifugal impeller in turning the flow to the radial direction has a shape which is inherently more difficult to fit with forced cooling channels, and adding material just adds to the root stress. The technology to actively cool compressor or turbine blades with cold gas injection is advanced, so if forced cooling is required it may be advantageous to consider a simpler blade shape. In this way the material temperature can be maintained well below the gas temperature.

Most of the experience of Westinghouse South Africa has been with the Centrifugal-type Circulators at temperatures up to $370^{\circ} \mathrm{C}$. The temperature limit ensured that the pressure vessel temperature was not exceeded without the need for internal insulation. The effectiveness of internal insulation could not be guaranteed after numerous cycles of rapid pressure variations.

On a slightly different topic - Why have an impeller at all? In one configuration of the NGNP a secondary loop to the reactor is proposed, where a $10 \%$ side stream of the reactor outlet is diverted to a test loop, before being returned to the reactor inlet, still at high temperature. The temperature in this loop is substantially above the current proven technology levels for circulator impellers. One solution to be considered is an ejector principle, where the $90 \%$ flow from the main circulator is accelerated to create a local relatively low pressure. The Bernoulli pressure drop is used to draw the $10 \%$ of the hot flow through the secondary test loop, before recovering the pressure through gradual deceleration and mixing the gas streams before passing through the reactor again. This technology is proven, and requires no moving parts.

\section{$\underline{\text { Drive Configuration }}$}

The motor in a circulator is never a factor on its own. The solution is always a motor-impellerbearing interplay to define the optimum configuration. The key factor when size is considered is the relative complexity of having a motor submerged in Helium contaminated with graphite dust, and having to bring in active cooling and power, relative to the relative simplicity of a motor and a gearbox at ambient conditions, but then having to deal with a shaft penetrating the vessel.

Dry Gas Seals (DGS) operate with very small clearances as a critical element to their effective operation. The shaft supporting bearing directly adjacent to the DGS needs to be very stiff, and this eliminates an Automatic Magnetic Bearing (AMB) as an option in this location ${ }^{2}$. AMB

\footnotetext{
${ }^{2}$ The alternative to AMBs is gas bearings, as used in the THTR Fuel Handling Circulators. Rotor weight could be limiting for the NGNP main circulator.
} 
bearings can be used far away from the DGS to provide additional shaft support. A shaft of $80 \mathrm{~mm}$ creates an axial thrust force of 35 tons at $7 \mathrm{MPa}$. It therefore makes sense to use Dry Gas Seals in a dual seal configuration to counter the thrust. More than one configuration is possible, as:

- It does not require that the second seal 'leak' contaminated helium. The pressure balancing chamber can be fed nitrogen from a high pressure source, with a spool valve matching the balance chamber pressure with the helium pressure, and a much smaller gearbox thrust bearing taking up the small differential force due to matching imperfections. This second DGS will then leak pure nitrogen.

- The DGS could be located on either side of the impeller in the "pods' of the "Fan" configuration illustrated. The pods are then designed as pressure vessels with atmospheric pressure inside, and each contain a bearing and a DGS. Power is then provided by means of a direct or angled drive shaft.

These factors count against Dry Gas Seal configurations because:

- They do require replacement at regular intervals, since they do wear slightly. They wear more during stop-start cycles, so it is better if they operate continuously.

- They do require extensive support systems to control and capture the leakage of contaminated helium.

- They leak more when stationary than when they rotate. This makes them more suitable for circulators that operate continuously.

- The DGS and gas leaking to it must be kept relatively cold $\left(<300^{\circ} \mathrm{C}\right)$. This may require cooled buffer gas.

This makes Dry Gas Seals less attractive, and they were thus avoided, in specific application needs, when it was possible.

The alternative is bearings inside the helium pressure boundary, and since helium tends to facilitate seizing, the trend is towards Automatic Magnetic Bearings (AMB). Effectively the $\mathrm{AMB}$ is a set of electro-magnets that pull on the shaft based on feedback of its relative position. Since each AMB has multiple coils and sensors, a set of AMBs (2 radial, one thrust) requires as many as 121 electrical power and sensing penetrations. The heavier the shaft and attachments (motor/impeller) the larger the currents that need to pass through the penetrations. The higher the shaft speed, the faster the corrections need to happen. Helium and its contaminant, graphite dust, will be the great enemy of the AMB. It can cause fretting of insulation, since the forces exerted will cause some coil vibration in response, and the distances between the penetrations and the vessel body cannot be infinite, hence the risk of short-circuits is real. One solution is to encapsulate the coils and penetrations, but the fact that helium is such a small atom does not exclude absorption, followed by cracking of the insulation when the pressure is reduced. The motor when submerged in helium is of course susceptible to the same failure mechanisms.

Another factor is the fact that the functioning of the motor and coils are dependent on preserving the circuits, and thus the temperature in these volumes must be maintained at survivable 
temperatures, say below $200^{\circ} \mathrm{C}$ as an upper limit. If the impeller is at $350^{\circ} \mathrm{C}$ or up to $500^{\circ} \mathrm{C}$ as proposed, this requires the motor and motor cavity to be cooled at a rate that compensates for scavenge heat from the heat shields, rotor and housings.

The required responsiveness of AMBs limits the length of cable that can be tolerated. The AMB cabinets must therefore be within about $50 \mathrm{~m}$ cable-length from the circulator itself.

A characteristic of AMBs are that they are not stiff. They allow substantial run-out before contacting the sacrificial emergency "catcher" bearings. This makes the circulator well-behaved in surge conditions, since the larger motion reduces the forces experienced by components. However, this flexibility also requires greater tip clearances on the impeller, which translates into greater leakage and higher inefficiencies. It is therefore important that the rotor stiffness and bearing locations maintain the run-out at impeller tips to an acceptable minimum.

The function of the "catcher bearings" is to eliminate rotor or AMB damage, should power to the system be lost. They can be roller bearings, but more often they are just soft bushings. The heavier and faster the shaft, the more energy they must absorb during a 'drop'. The amount of damage can be limited by active regenerative braking, and the HTF $100 \mathrm{~kW}$ circulator experienced many drops onto the catcher bearings without any measured damage.

Power penetrations share a common feature with the AMB Penetrations. As the size of the circulator and its speed increases, the torque required increases. This requires higher currents at higher frequencies. At some point the voltage needs to be increased to transmit the power without overheating the penetrations. This in turn increases the risk of short-circuits in a helium environment. This can be countered by increasing the number of electrical penetrations, but each penetration weakens the vessel and therefore needs to be spaced. As the vessel size is increased to accommodate a bigger motor and more penetrations, the mass increases exponentially. Whereas a $100 \mathrm{~kW}$ circulator's mass was 4 tons, one five times more powerful was estimated to be nine times heavier.

\section{Experience with Submerged AMB Circulators}

The circulator referenced was a centrifugal type, with overhung bearing support driven by a submerged $100 \mathrm{~kW}$ motor, operating in helium, but it functioned in nitrogen/air without modification. The design speed of the rotor was $27,000 \mathrm{rpm}$ with a tip speed of $365 \mathrm{~m} / \mathrm{s}$. It operated in pressures ranging from $100 \mathrm{kPa}$ to $9 \mathrm{MPa}$ at inlet gas temperatures up to $280^{\circ} \mathrm{C}$. It had two radial and one thrust AMB. The motor and its volume were water cooled, and the effective ambient conditions were maintained below $100^{\circ} \mathrm{C}$. Vessel temperatures were of course substantially higher, due to the heating effects from the primary gas flow. 
The design experience with the circulator, including the operating experience, was captured in two papers presented at HTR Conferences (References 18 and 19). The key observation was that circulators are prone to vibration, and in combination with helium, placing electrical components inside a pressure-varying helium environment is not without risk. 


\section{APPENDIX D. NUCLEAR RENAISSANCE: IMPACT ON INFRASTRUCTURE}

See separate Power Point file 


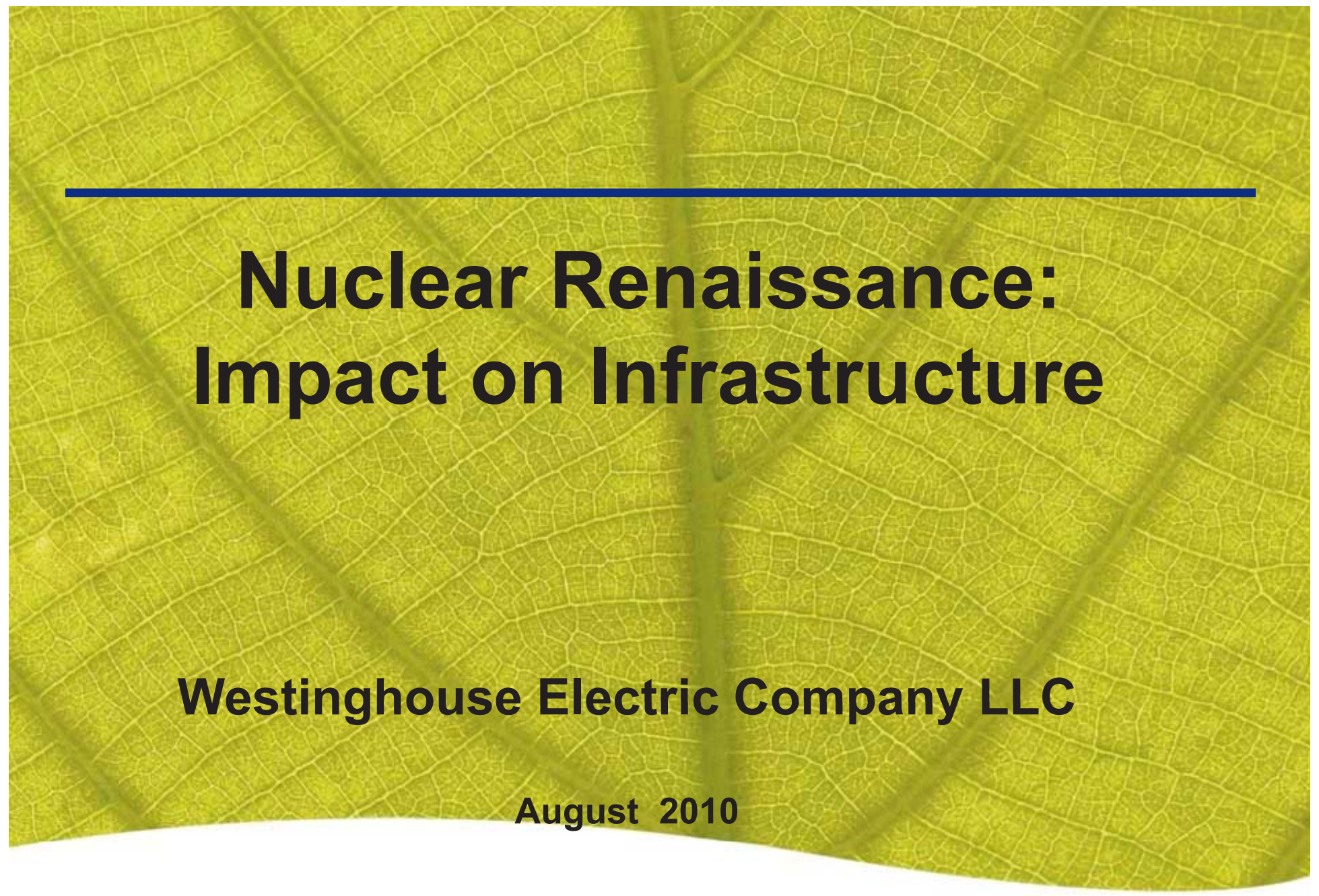

(W) Westinghouse 


\section{Outline}

- Projection of New Nuclear Build

- Uranium Supply

- Uranium Conversion

- Uranium Enrichment

- Nuclear Fuel Manufacture

- Large Forging Requirements and Capacity

- Heavy Component Manufacture

- Other Key Materials and Equipment

- Steam Generator Tubing

- Specialized Nuclear Equipment

- Transportation of Heavy Components

- Heavy Lift Cranes

- Module Manufacturing

People Challenges

- Regulatory Authority Challenges 


\section{Worldwide Nuclear Power Capacity Projections}

Nuclear Capacity through 2050

(reference/median cases)
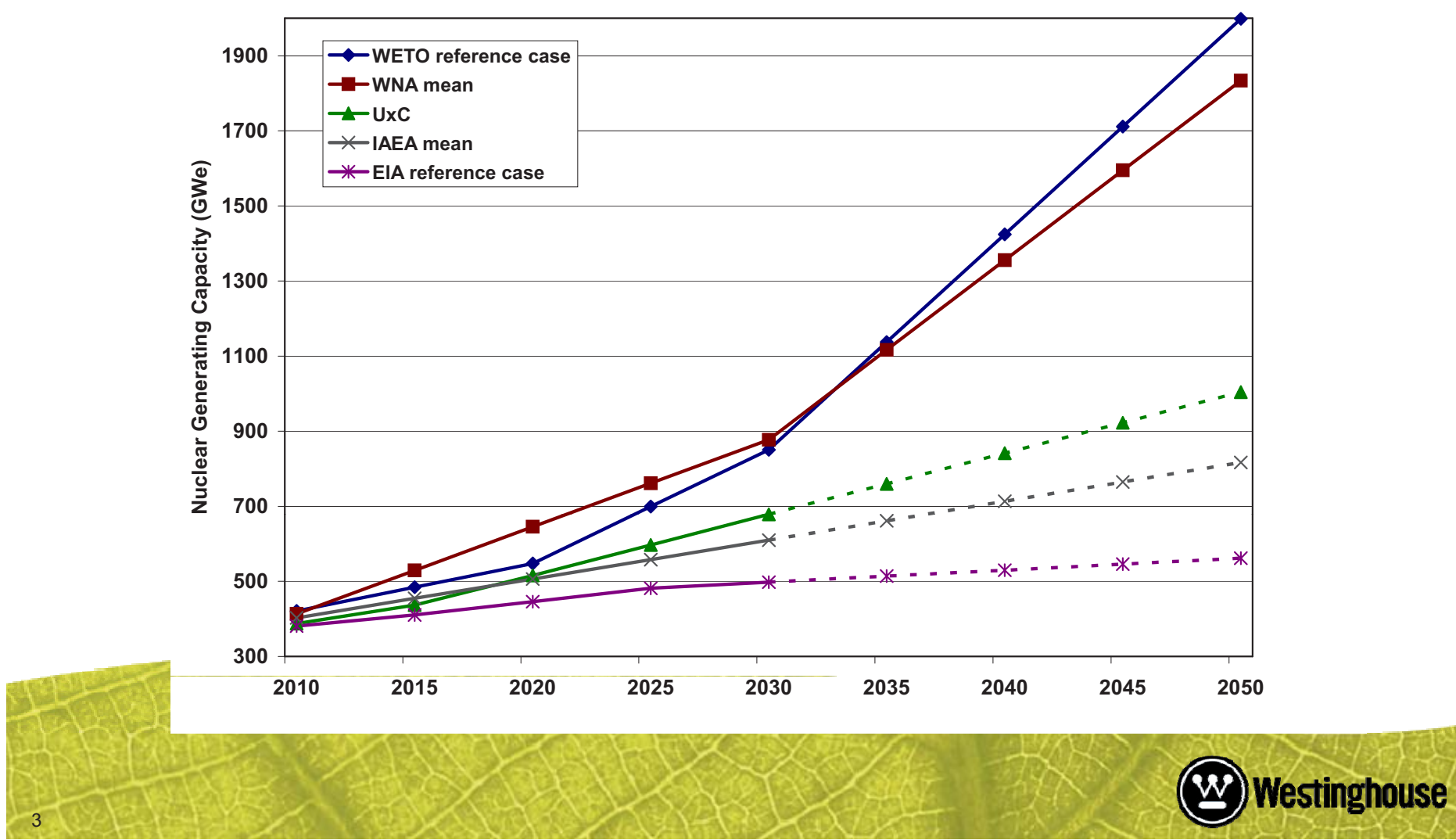


\section{Projections for New Nuclear by Geographical Region}

- Global economic growth
Security of energy
supplies
Environmental concerns
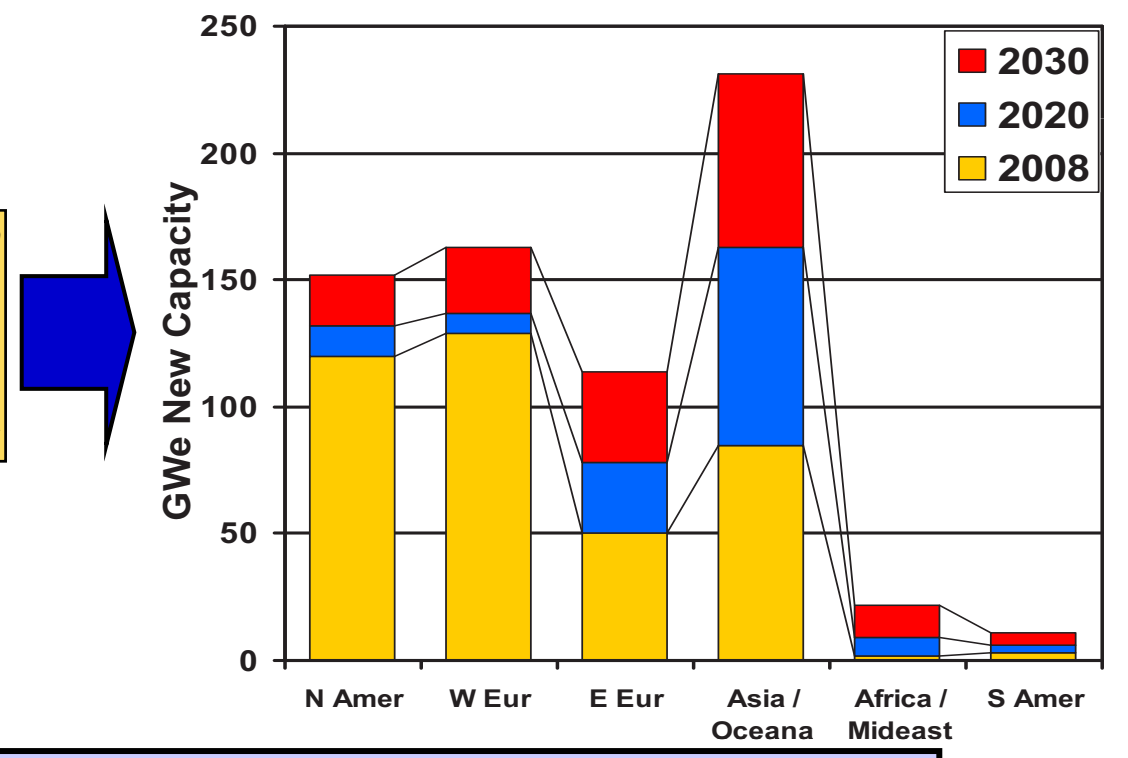

But, external factors are delaying some markets

- Weak demand and economies

- Limited progress on carbon pricing

- Low natural gas prices in North America 


\section{Nuclear Capacity Projections (Specific Countries - mid term)}

\begin{tabular}{|c|c|c|}
\hline Country & Under Construction ${ }^{1}$ & Planned/Proposed $^{2}$ \\
\hline China & 23 & 150 \\
\hline Finland & 1 & \\
\hline France & 1 & \\
\hline India & 4 & 60 \\
\hline Japan & 2 & 12 \\
\hline Italy & 0 & \\
\hline Russia & 10 & \\
\hline South Africa & 0 & 10 \\
\hline South Korea & 6 & \\
\hline Turkey & $\mathbf{0}$ & \\
\hline UAE & 4 & \\
\hline Vietnam & 2 & 14 \\
\hline United Kingdo & om & \\
\hline United States & $\frac{5}{258}$ & $\frac{23}{n n 2}$ \\
\hline
\end{tabular}

Notes: (1) Includes plants with firm construction contracts

(2) Includes only countries with announced plans and agreements 


\section{Traditional Nuclear Fuel Cycle}

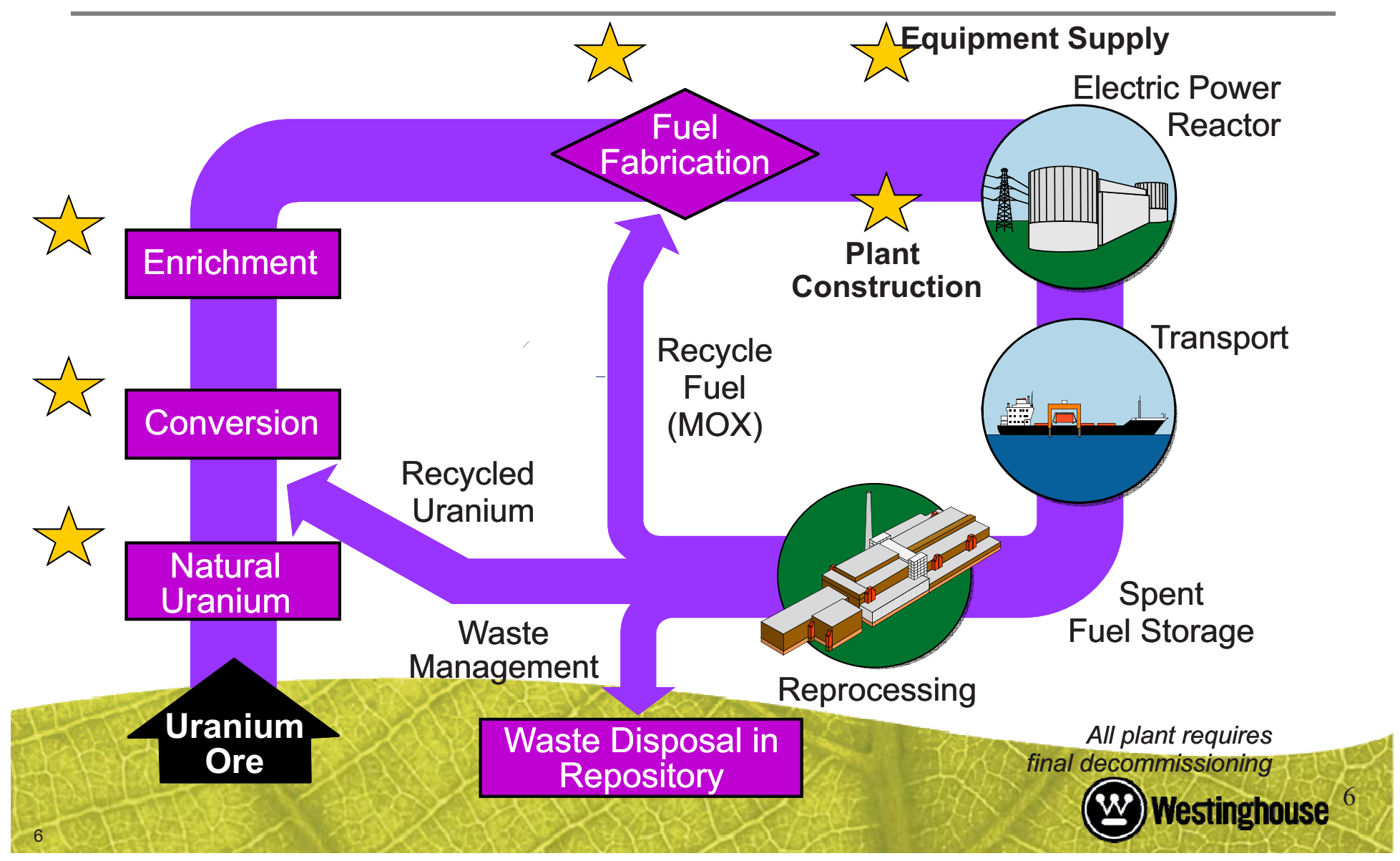




\section{Uranium Supply}

- Supply of uranium

- Underground mines

- Open pit mines

- In-situ leach mining

- By-products (e.g., copper and phosphate mining)

- In 2009

- $57 \%$ from conventional mining

- $36 \%$ from in-situ leaching

- $7 \%$ from by-products

- Leading mining production countries

- Kazakhstan 27\%

- Canada 20\%

- Australia $16 \%$

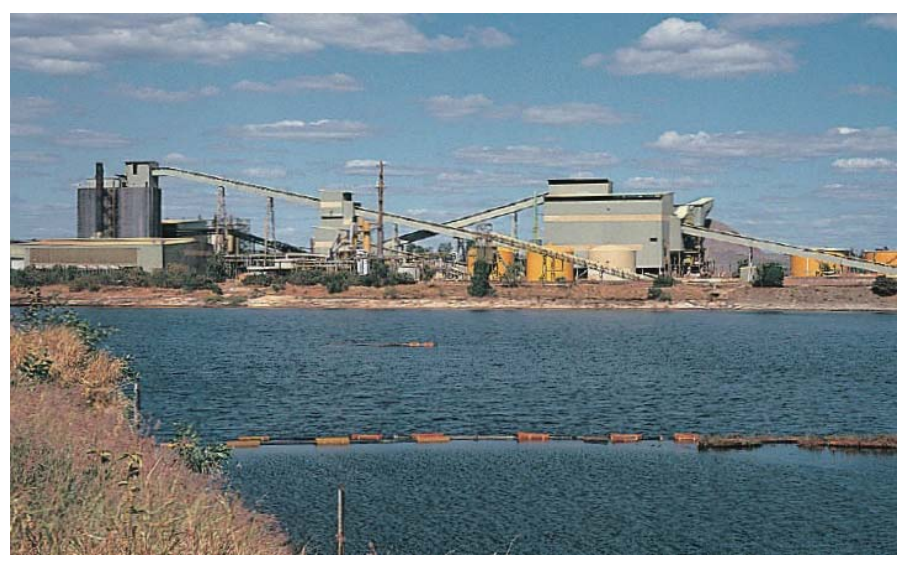

Ranger Uranium Mine Australia

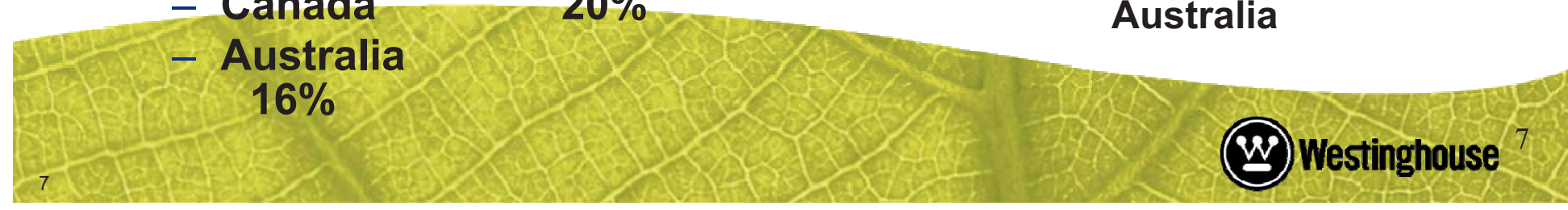




\section{Uranium Mining Control ${ }^{1}$ (annual capacity)}

- Since the early 1990 s, uranium production industry has consolidated

- In 2009, 10 companies marketed $89 \%$ of the world's uranium mine production

\begin{tabular}{l|l|l}
\multicolumn{1}{c}{ Company } & tonnes U & \multicolumn{1}{c}{$\%$} \\
Areva & 8623 & 17 \\
Camoco & 8000 & 16 \\
Rio Tinto & 7963 & 16 \\
KazAtomProm & 7433 & 15 \\
ARMZ & 4624 & 9 \\
BHP Billiton & 2955 & 6 \\
Navoi & 2429 & 5 \\
Uranium One & 1368 & 3 \\
Paladin & 1210 & 2 \\
GA/Heathglate & 583 & 1 \\
Other & 5384 & 11 \\
Total & 50,572 & $100 \%$
\end{tabular}

Notes: (1) World Nuclear Association - May 2010 Update 


\section{Known Recoverable Uranium Reserves $(2007)^{1}$}

Country

Australia

Kazakhstan

Russia

South Africa

Canada

United States

Brazil

Namibia

Niger

Ukraine

Jordan

Uzbekistan
Tonnes Uranium

$1,243,000$

817,000

546,000

435,000

423,000

342,000

278,000

275,000

274,000

200,000

112,000

111,000
$\%$ of World

23

15

10

8

8

6

5

5

5

4

2

2

World Total

413,000

Notes: (1) Word Nucle $5,469,000$ 


\section{Facts About Uranium Reserves}

- Uranium is a relatively common metal; economic concentrations of it are not uncommon

- World's known uranium resources have increased in steps (e.g., 15\%) over short periods because of increased exploration; Uranium 2009 Red Book now lists identified resources at $\mathbf{6 . 3}$ million tonnes

- Our knowledge of geology indicates with confidence that identified resources are a small fraction of what is actually there

- Known uranium resources will increase with increased exploration as shown by history

- Increased uranium market price drives increased exploration, resulting in greater identified resources

- Current demand is $\sim 64,000$ tonnes/year; 400 new reactors by 2035 would increase demand to $\sim 138,165$ tonnes/year - even at this large increase, less than half of the identified resources would be consumed 


\section{Relationship Between Exploration and Known Uranium Reserves}

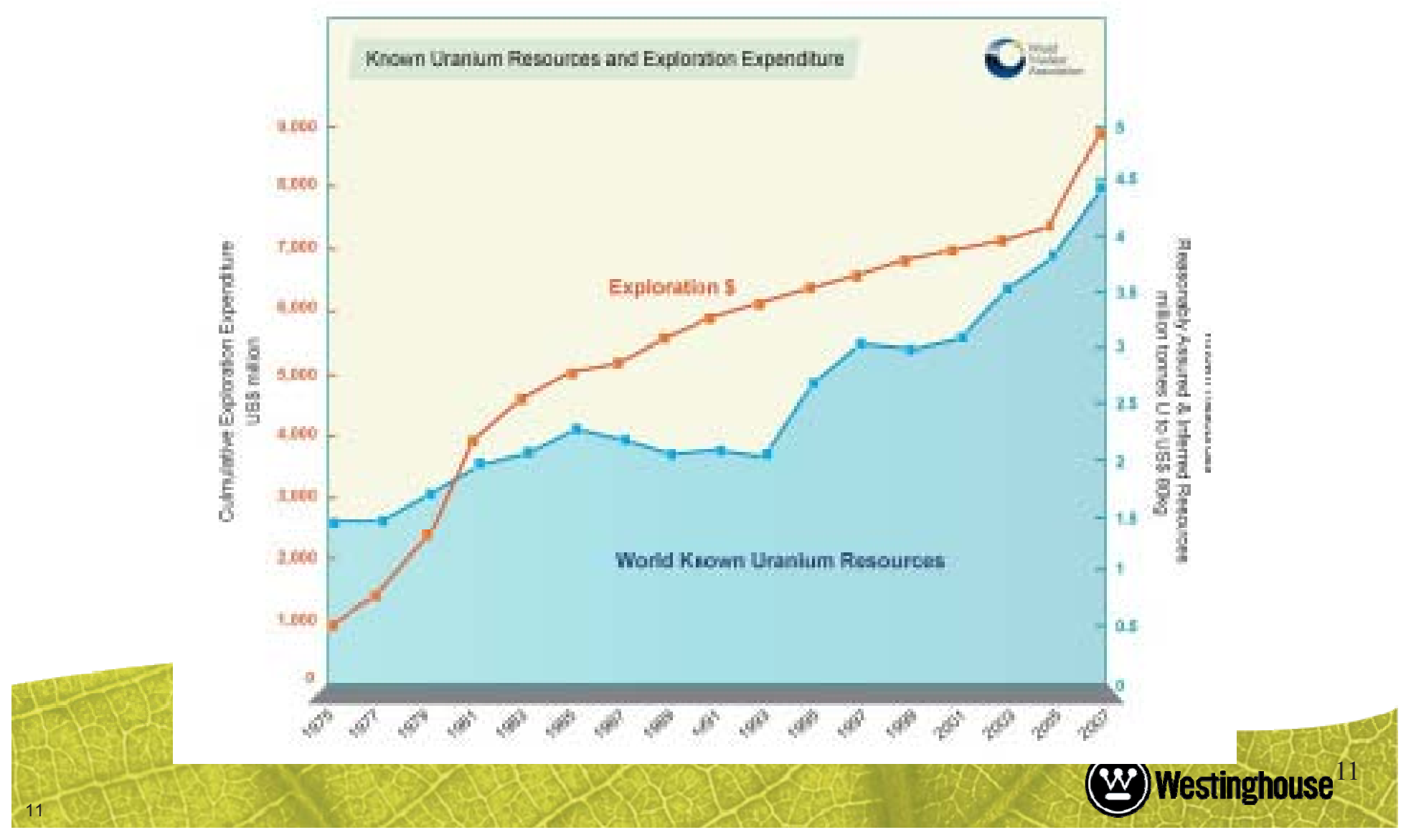




\section{World Uranium Supply ${ }^{1}$ (tonnes U)}

Supply Method

$\underline{2009}$

2020

2030

Mine Production

49,340

78,630

70,150

Russian HEU

10,020

380

380

Tails Upgrading 4

2,700

3,470

0

Other Already Mined U

Total Supply

$\underline{6,550}$

$\underline{5,780}$

$\underline{5,780}$

68,610

88,260

76,310

Requirements ${ }^{1,2}$

Requirements $^{3}$

63,980

79,400

92,120

96,750

123,350

Notes: (1) Reference - Nuclear Engineering International, Sep 2009

(2) Reference case nuclear capacity projection ( $524 \mathrm{GWe}$ by 2030 )

(3) High case nuclear capacity projection (746 GWe by 2030)

(4) Russians use $0.11 \mathrm{wt} \% \mathrm{U}^{235}$ tails assay in their enrichment while others typically use $0.25 \mathrm{wt} \% \mathrm{U}^{235}$ 


\section{Economic Factors that Impact Uranium Supply and Use}
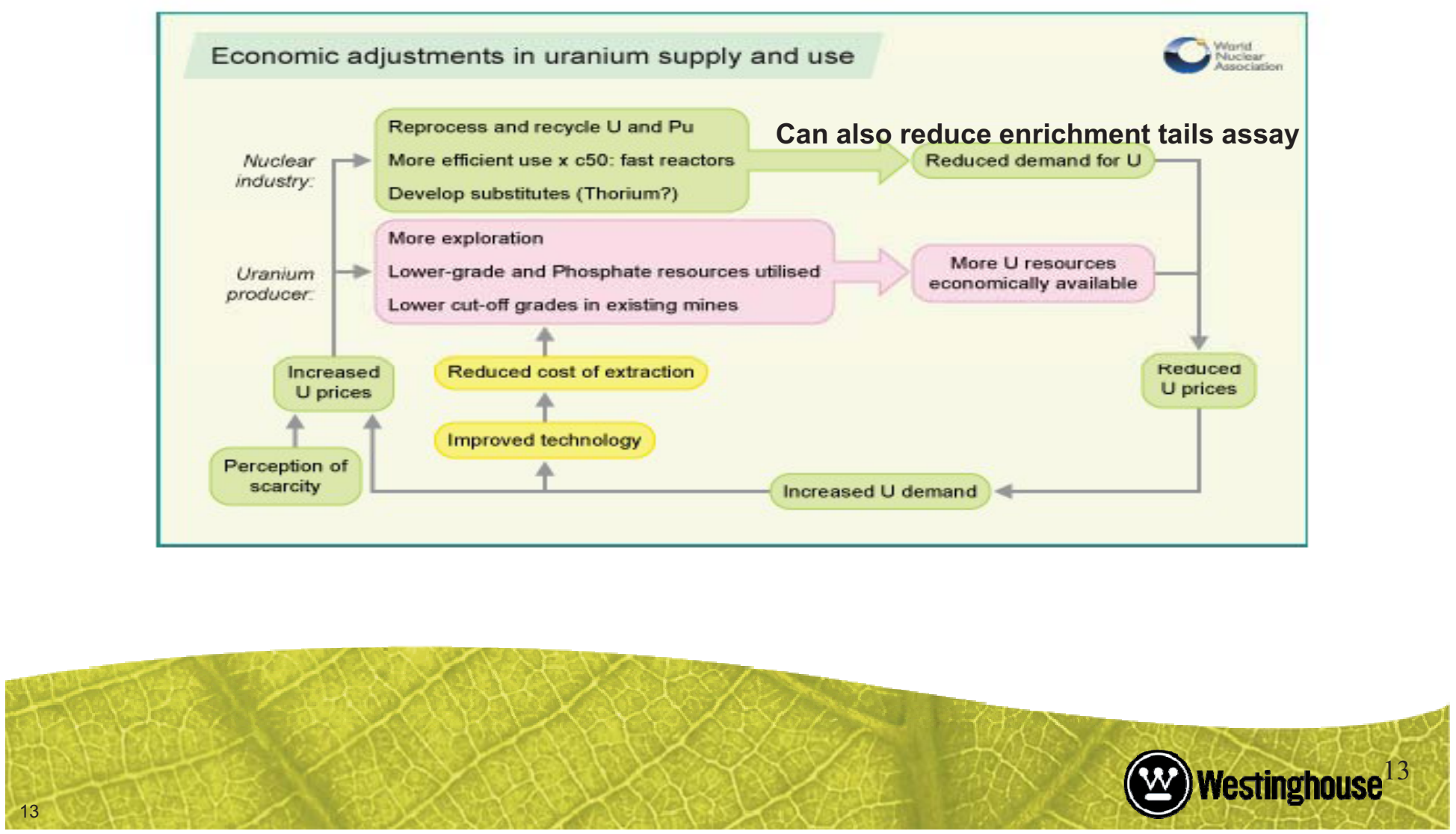


\section{Uranium Conversion}

- Uranium leaves the mine as $\mathrm{U}_{3} \mathrm{O}_{8}$ concentrate, but still containing some impurities

- It needs to be refined further and converted to $\mathrm{UF}_{6}$ so that it can be enriched as a gas

- There are two process used worldwide

- Dry fluoride volatility process in the U.S.

- Wet process everywhere else

- Commercial conversion plants are operating in

- U.S.

- Canada

- France

- United Kingdom

- Russia

- China

- Purified UF 6 liquid is loaded into steel shipping cylinders where it cools and solidifies into a crystalline solid 


\section{World Primary Conversion Capacity ${ }^{3}$}

\section{Company}

Cameco, Port Hope

Cameco, Springfields

JSC (Atomenergoprom)

Comurhex (Areva)

Converdyn, Metropolis

CNNC, Lanzhou

IPEN
Country

Canada

U.K.

Russia

France

U.S.

China

Brazil
Capacity (Tonnes U) 1

12,500

6,000

$25,000^{2}$

14,500

15,000

3,000

90

76,090

Note: (1) Nameplate capacity

(2) Operating Capacity estimated at only 12,000 to 18,000 tU/yr currently

(3) Reference - Nuclear Engineering International, Sept 2009 


\section{Uranium Enrichment A Vital Part of the Nuclear Industry}

- Most of the world's nuclear power reactors are Light Water Reactors requiring fuel with enriched uranium

- Natural uranium contains only $0.71 \mathrm{wt} \% \mathrm{U}^{235}$ isotope, the fissile component of uranium; the remainder is $U^{238}$ a fertile isotope

- PWRs currently use enrichments

-1.3 to $3.8 w t \% U^{235}$ (initial cores)

- Up to 4.95 wt\% U235 (equilibrium cores)

- Each 1,000 MWe reactor has approximately 72 metric tonnes of enriched uranium in the core

- Refueling is required every 12 to 24 months when one-third to one-half of the fuel is replaced 


\section{Facts About Enrichment}

- Enrichment is measured in Separative Work Units (SWUs)

- SWU measures the quantity of separative work performed to enrich a given amount of uranium to a specific $U^{235}$ concentration

- The SWU required is a function of the amount of uranium processed, the degree to which it is enriched, and the level of depletion of the remaining uranium (i.e., tails assay)

- There is always a trade-off between the cost of enrichment (SWU) and the cost of uranium (U). For one $\mathrm{kg}$ of $5 \mathrm{wt} \% \mathrm{U}$ product:

- $7.9 \mathrm{SWU}$ if enrichment plant is operated at a tails assay of $0.25 \%(10.4 \mathrm{~kg}$ $\mathrm{U}$ feed)

- $8.9 \mathrm{SWU}$ if enrichment plant is operated at a tails assay of $0.20 \%(9.4 \mathrm{~kg}$ $\mathrm{U}$ feed)

- About $140,000 \mathrm{SWU}$ is required to enrich the annual fuel loading for a typical 1000 MWe PWR

- Enrichment accounts for almost half the cost of nuclear fuel and about $5 \%$ of the total cost of electricity generated 


\section{Enrichment Processes}

- Gaseous Diffusion

- Force $\mathrm{UF}_{6}$ gas under pressure through porous membranes where lighter $U^{235}$ molecules preferentially pass through the membrane

- Very energy intensive $(70 \%$ of total enrichment cost)

- Gaseous Centrifuge

- Heavier U238 molecules concentrate towards the outer edge of the rotating cylinder

- Energy efficient (only about $2 \%$ of the energy used in gaseous diffusion)

- Laser

- Tuned laser ionizes $U^{235}$ (but not $U^{238}$ ) as a metal vapor which is collected on a negatively charged plate

- Not available commercially yet

- Lower capital costs and can be economically run at lower tails assay

- Aerodynamic

- Jet nozzle demonstrated in Brazil

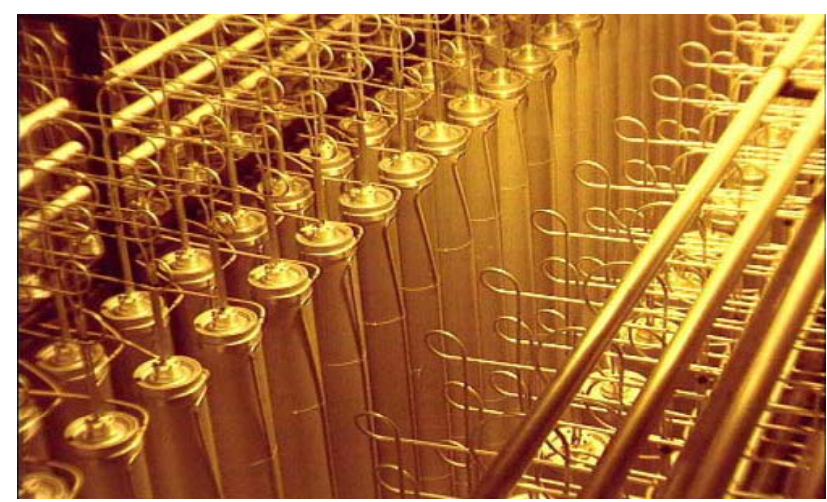

- Helikon vortex tube demonstrated in South Africa

Stationary wall centrifuge being developed in South Africa

\section{Centrifuge Cascades}




\section{World Enrichment Capacity ${ }^{1}$ (operational and planned)}

Company \& Plant

Areva, George Besse I \& II

Urenco, Gronau

Almelo

Capenhurst

JNFL, Rakkaasho

USEC, Paducah \& Piketon

Urenco, New Mexico

Areva, Idaho Falls

Tenex (4 locations)

CNNC, Hanzhun \& Lanzhou

Others (in Pakistan, Brazil, Iran)
Country

France

Germany

Netherlands

U.K.

Japan

U.S.

U.S.

U.S.

Russia

China $\underline{2008}$

$10,800^{2}$

12,200

0

$8,000^{2}$

0

0

25,000

1,300

100

56,200 $\geq 2015$

7,000

14,000

750

3,800

5,700

$>1,000$

38,000

3,000

Total

Notes: (1) Thousand SWU/year; centrifuge capacity unless otherwise stated

(2) Gaseous Diffusion Capacity 


\section{Nuclear Fuel Manufacture}

- Manufacturing Nuclear Fuel

- Requires very high quality

- Is highly regulated

- Necessitates substantial experience with lessons learned fed back into the processes

- The Consequences of fuel failures are very large

- Reactor downtime

- Increased radiation to staff

- Increased regulatory scrutiny

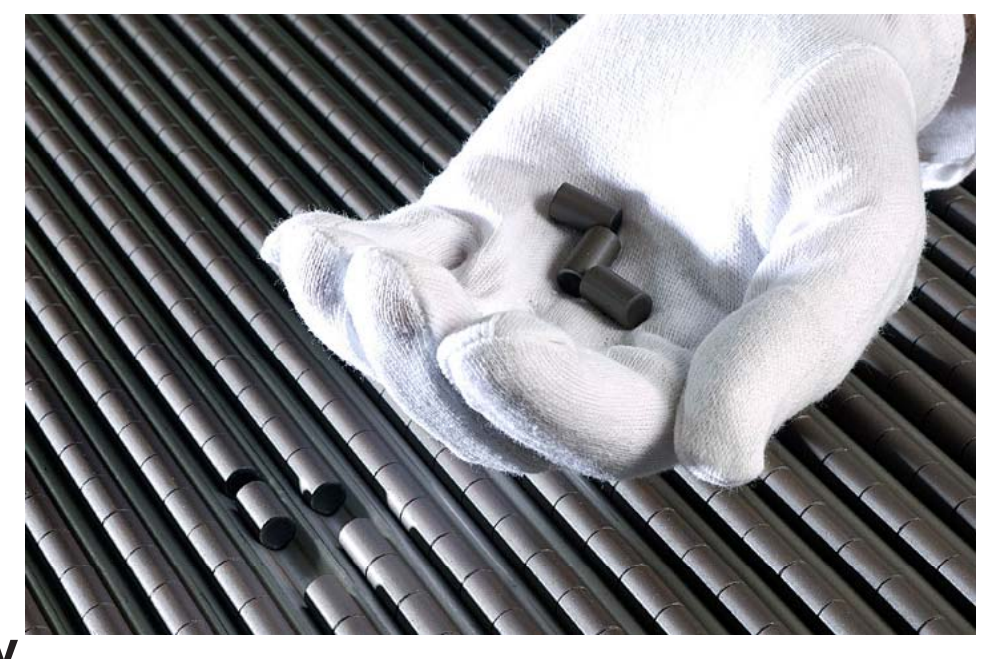

- Security, safeguards, and accountability are absolute requirements 


\section{Worldwide Nuclear Fuel Manufacturing Capacity (LWR only)}

\begin{tabular}{|c|c|c|c|}
\hline \multicolumn{4}{|c|}{ Commercial Nuclear Fuel Manufacturing Facilities (LWR) } \\
\hline Country & Facility Name & $\begin{array}{c}\text { Design Capacity } \\
\text { (t HM/year) }\end{array}$ & $\begin{array}{c}\text { Start of } \\
\text { Operation }\end{array}$ \\
\hline Bclgium & FBFC International LWVR & 603 & 1081 \\
\hline Brazil & FCN Resende - Unit 1 & 243 & 1982 \\
\hline Chira & Yibin Nuclear Fuel Element Plant & 203 & 1908 \\
\hline Frarce & FBFC - Romans & 1.403 & 1979 \\
\hline Genmany & Advanced Nuclear Fuels GmbH Lingen Plant & 653 & 1979 \\
\hline India & NFC & 335 & 1998 \\
\hline Japan & Global Nuclear Fuel-Japan Co. Ltd. (GNF-J) & 753 & 1970 \\
\hline JapdII & 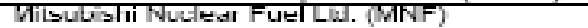 & $44 J$ & 1972 \\
\hline Japan & Nuclear Fuel industry Lid. (NFI Kumaton) & 284 & 1972 \\
\hline Japan & Nuclear Fuel Industry Ltd. (NFI Tokai) ${ }^{2}$ & 253 & 1890 \\
\hline Kosakkhstan & Ulba Mctallurgioal Plant (UMP) & 2,803 & 1010 \\
\hline Korea, Republic of & PWR Fuel Fabrication Plant & 403 & 1898 \\
\hline Russian Federation & Machine - Building Plant (NWER) & $62 J$ & 1953 \\
\hline Russian Federation & Novos birsk Chemical Concentrates Plant & 1,003 & 1949 \\
\hline Spain & Fabrica de combust ble & 403 & 1885 \\
\hline Sweden & Westinghous: Electric Sveden AB & 603 & 1971 \\
\hline United Kingdom & NDA Springfields OFC LWR Line & $33 \jmath$ & 1906 \\
\hline Unlted States of America & Columbla (Westinghouse Electric) & 1,150 & 1980 \\
\hline United States of America & Richland (ANF) & 703 & 1970 \\
\hline United States of America & Wilmington $(\mathrm{GNF})^{2}$ & 1,200 & 1882 \\
\hline & Total & 11,213 & \\
\hline
\end{tabular}

'Data Is from the intemational Aiomic Energy Agency (IAEA) Nuclear Fuel Cycle information System (NFCIS)-

${ }^{2}$ Denotes BWR Fuel

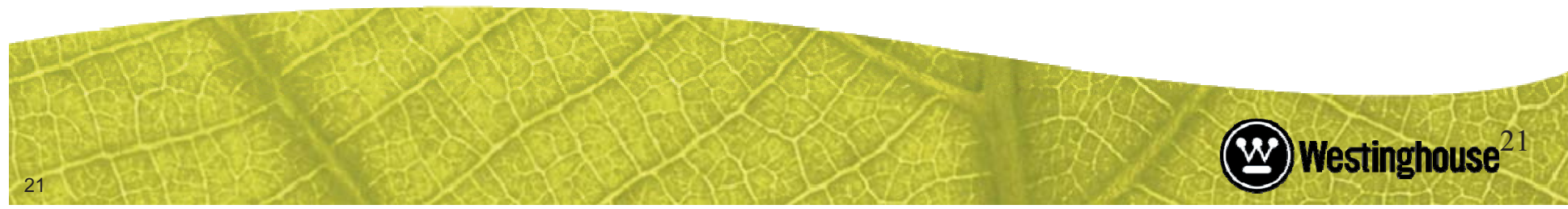




\section{Nuclear Fuel Manufacturing Capacity Requirements}

- Each 1000 MWe plant has about 72 tonnes heavy metal in its core

- Reactors refuel between 12 and 24 months, replacing between one-third and one-half of the core

- On average, each reactor requires about 24 tonnes HM of fuel per year

- With world capacity at $\sim 14,250$ MT/year LWR fuel (with Kazakhstan) - this will support about 5901000 MWe reactors

- Without Kazakhstan capacity - this will support $\sim 4801000$ MWe reactors

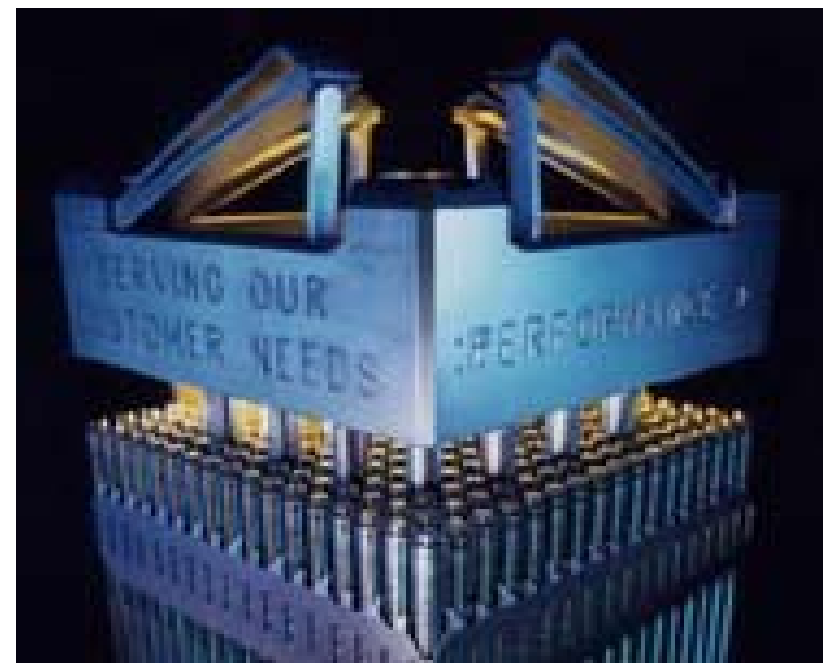

- Majority of growth in LWR fuel manufacturing capacity will be in China and India with their stated localization programs

Top View of Nuclear Fuel Assembly 


\section{Forging Requirements for New Nuclear Plants}

- All Generation III and III+ plants utilize more forgings than previously

- Alleviate concerns for pressurized thermal shock of the RPV

- Reduce the cost of weld inspection over the life of the plant

- These modern plants utilize up to 4,000 tonnes of forgings, about twice the amount of Generation II plants

- Large components (e.g., RPVs and SGs) require some forging capacities of $14,000-15,000$ tonne presses taking up to 600 tonne ingots

- Suppliers of such forgings must be accredited with materials certificates and must meet rigorous quality standards, e.g., NQA-1

- Forging capacity has been added recently to meet the growing demand for nuclear forgings, e.g., JSW, Doosan, and China First Heavy Industries 


\section{Reactor Pressure Vessel Construction}

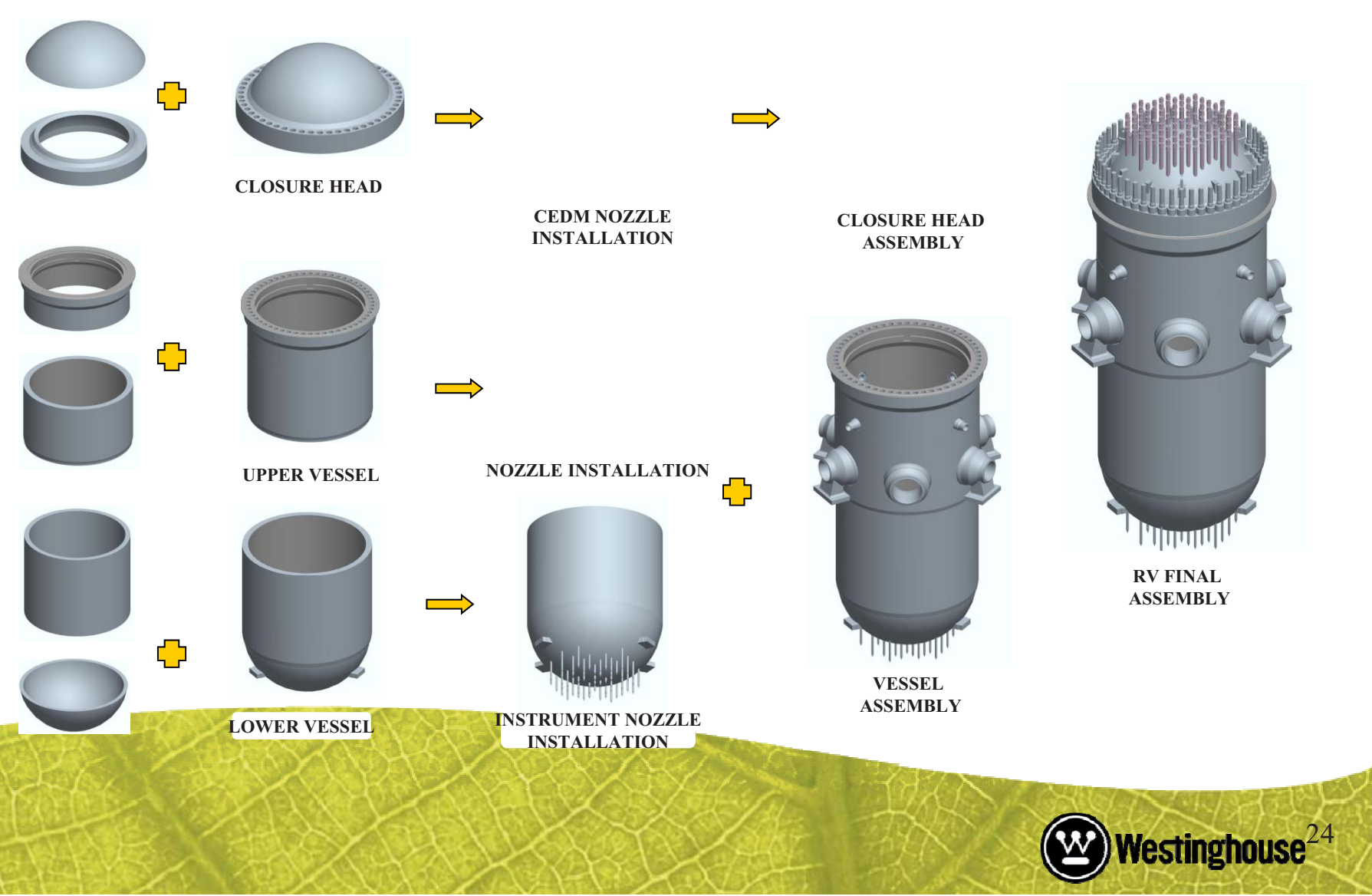




\section{Steam Generator Construction}

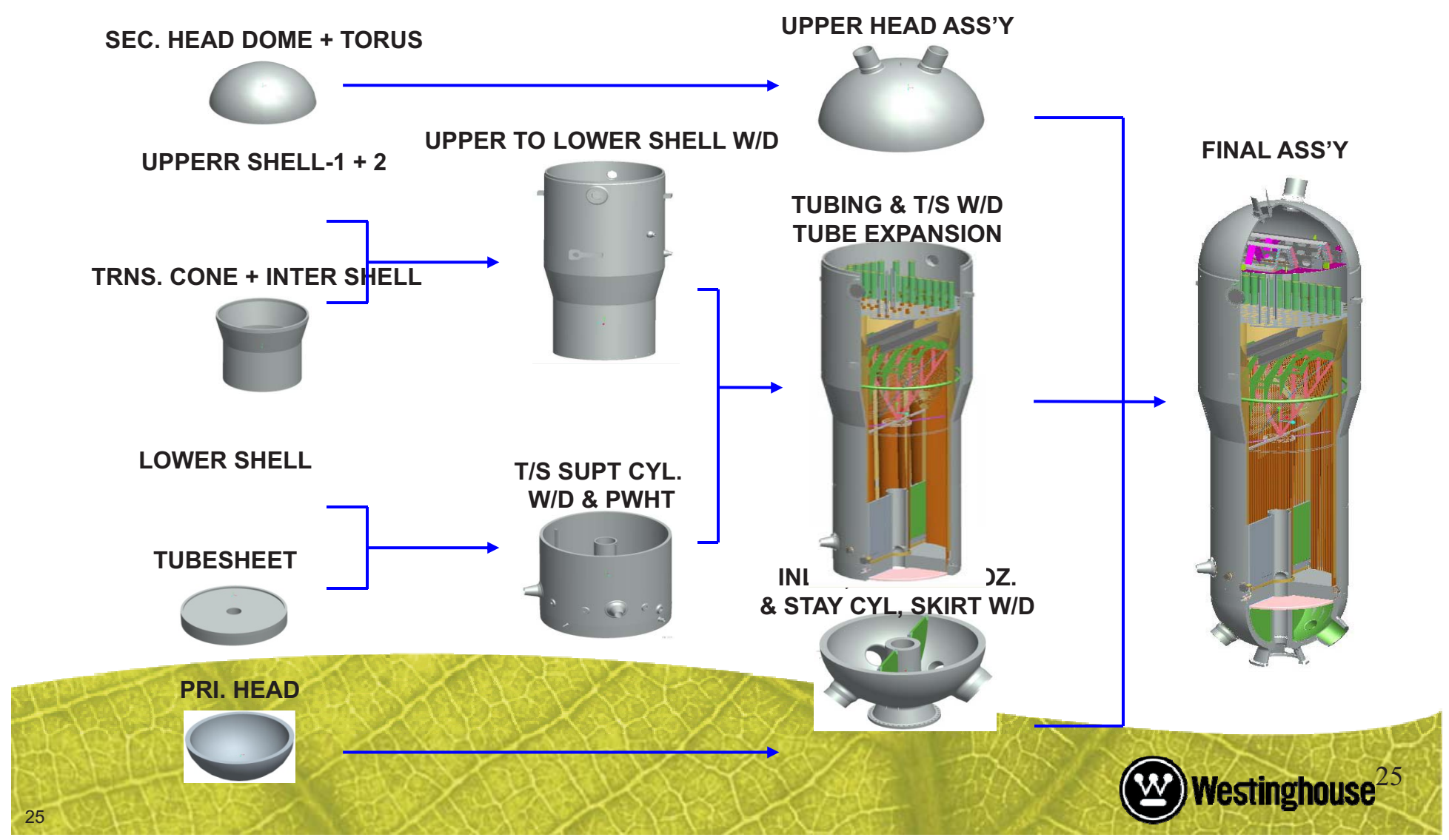




\section{Forged Ingot Being Processed into RPV}
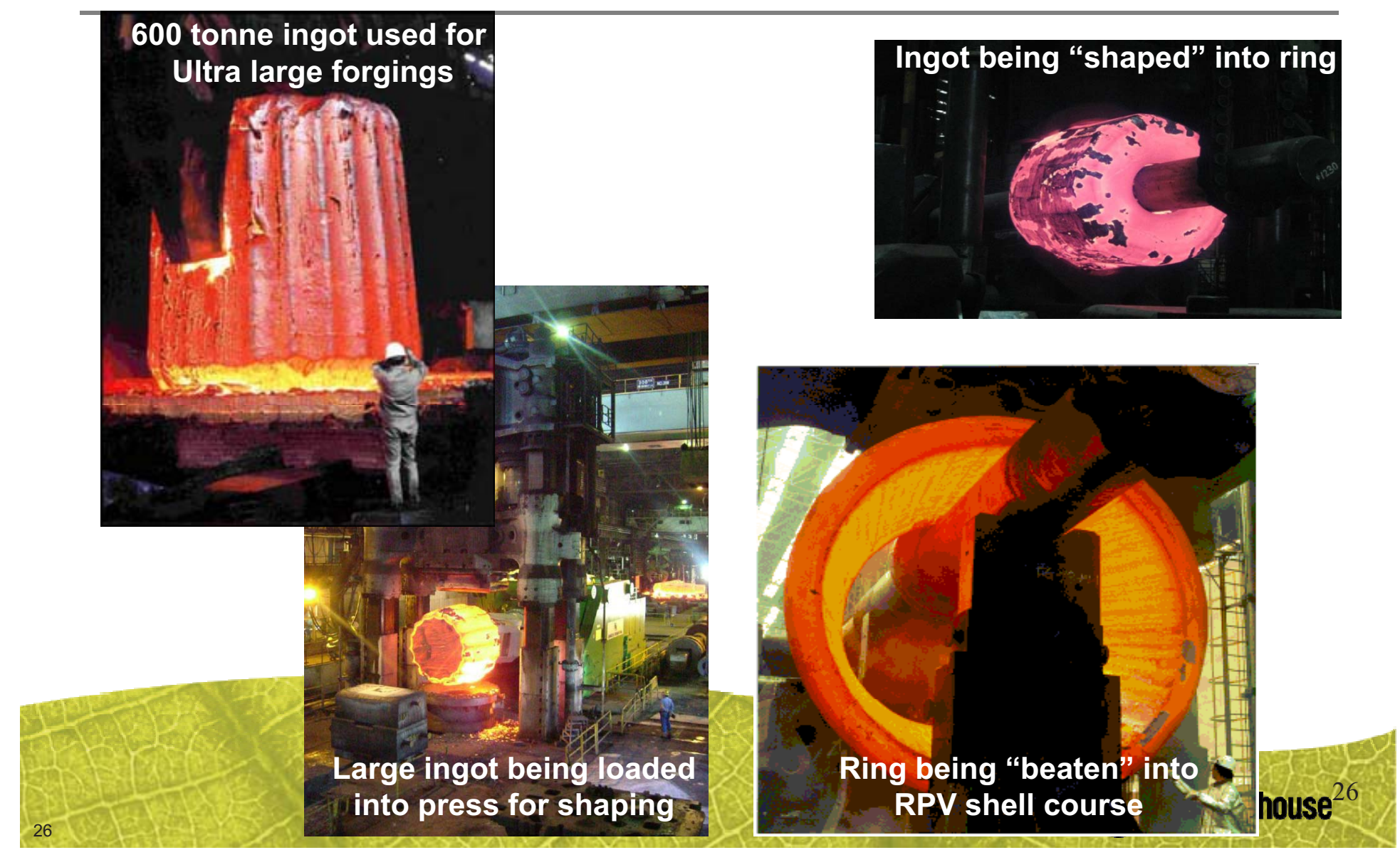


\section{Heavy Forging Capacity World Summary}

\begin{tabular}{|c|c|c|c|c|c|}
\hline \multicolumn{6}{|c|}{ Heavy Forging Capability Summary ${ }^{1}$ (Partial Listing) } \\
\hline Country & Company & $\begin{array}{l}\text { Heavy Forging } \\
\text { Press, Mid 2009 }\end{array}$ & $\begin{array}{l}\text { Heavy Forging } \\
\text { Press } 2013^{2}\end{array}$ & $\begin{array}{l}\text { Max. Ingot } \\
2009 / 2013^{2}\end{array}$ & $\begin{array}{l}\text { NPP Sets/Year } \\
2009 / 2012\end{array}$ \\
\hline Japan & Japan Steel Works (JSW) & $14,000 \mathrm{t}$ & $14,000 \mathrm{t} \times 2$ & $600 / 650 \mathrm{t}$ & $6 / 12$ \\
\hline Japan & $\begin{array}{l}\text { Japan Casting and Forging } \\
\text { Corporation (JCFC) }\end{array}$ & Not Available & $\begin{array}{l}13,000 \text { from } \\
2010\end{array}$ & 500 & Not Available \\
\hline $\begin{array}{l}\text { South } \\
\text { Korea }\end{array}$ & Doosan Corporation & 13,000 & $\begin{array}{l}17,000 \text { from } \\
2010\end{array}$ & 540 & Not Available \\
\hline China & $\begin{array}{l}\text { China First Heavy Industries } \\
(\mathrm{CFHI})\end{array}$ & $15,000,12,500$ & No Change & 600 & $5 / 5$ \\
\hline China & $\begin{array}{l}\text { Shanghai Electric Heavy } \\
\text { Industries Group } \\
\text { Corporation (SEC) }\end{array}$ & 12,000 & No Change & 600 & $2.5 / 6$ \\
\hline China & China Erzhong + Dongfang & $12,700,16,000$ & No Change & 600 & $5 / 5$ \\
\hline India & Larsen \& Toubro Ltd. & 9,000 & 15,000 & 600 (in 2011) & Not Available \\
\hline Russia & OMZ Izhora $^{3}$ & 12,000 & 15,000 & 600 & $2 / 4$ \\
\hline \multicolumn{5}{|c|}{ Total Sets Identified: } & $20.5 / 32$ \\
\hline \multicolumn{6}{|l|}{ Notes: } \\
\hline 1 & \multicolumn{5}{|c|}{ Source - "Heavy Manufacturing of Power Plants" - World Nuclear Association } \\
\hline 2 & \multicolumn{5}{|c|}{ Press capacity and ingot sizes are in metric tons. } \\
\hline 3 & \multicolumn{5}{|c|}{ Will not export. Forgings are required for Russian nuclear plant build program. } \\
\hline
\end{tabular}

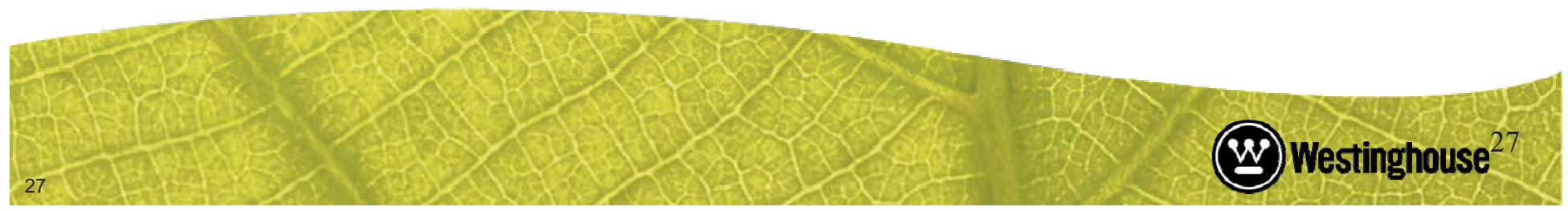




\section{Heavy Component Manufacturing (Indicative Number of NPPs per year)}

- Substantial capacity exists worldwide

- Doosan (Korea)

- MHI (Japan)

- IHI (Japan)

- ENSA (Spain)

- Mangiarotti (Italy)

- Skoda Power (Czech Republic)

- Bharat Heavy Electricals (India)

- Larsen \& Toubro (India)

- Babcock (Canada)

- Shanghai Boiler Works (China)

- Harbin Boiler Works (China)

- Dongfang Boiler Co. (China)

- OMZ Izhorskiye Zavody (Russia) 4

- JSC Machine Building (Russia)

- B\&W NPG (U.S.)

- Areva (France)

- Areva/Northrup Grumman (U.S.) Totals
Current $\geqq 2012$

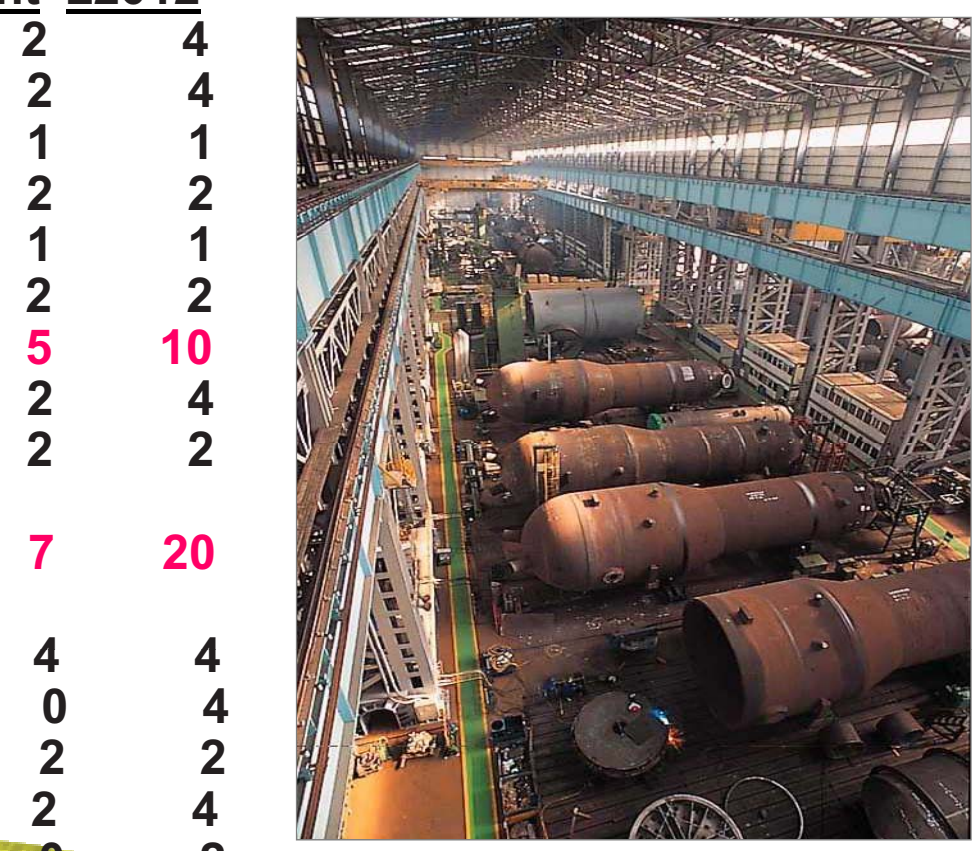

$\frac{2}{66}$ 


\section{Other Key Long Lead Materials or Specialized Equipment}

- Steam Generator Tubing

- Turbine Generators

- Reactor Vessel Internals

- Control Rod Drive Mechanisms

- Reactor Coolant Pumps

- Containment Vessels/Liners

- Large Cranes (e.g., polar crane)

- Instrumentation \& Controls Systems

- Plant Simulators

- Emergency Diesel Generators

- Specialized Valves (e.g., safety relief valves)

- Safety Grade Pumps

- Structural Modules

- Electric Main Step-up Transformers 


\section{Steam Generator Tubing}

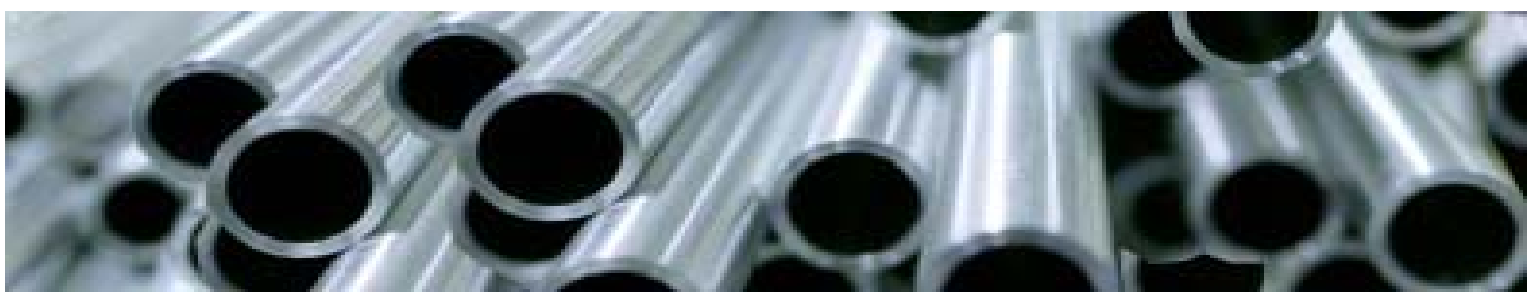

- Each 1000 MWe PWR requires 260 miles of I 690 tubing

- Critical long lead material with limited western suppliers

- Sandvik (Sweden)

- Sumitomo (Japan)

- Valinox (France)
3 plants/year

3 - 4 plants/year

2 plants/year

- Unclear from where Russia, India, and China are/will be getting their tubing

- Clearly, the capacity of SG tubing manufacture does not match the capacity of SG component manufacture 


\section{Specialized Nuclear Equipment (Representative Suppliers) $^{1}$}

\begin{tabular}{|c|c|c|}
\hline \multicolumn{3}{|c|}{ SUPPLY MANAGEMENT OF SPECIALIZED EQUIPMENT } \\
\hline Reactor Vessel Internals & Westinghouse Electric Company, LLC, Newington Plant & U.S. \\
\hline & Doosan Corporation & Korea \\
\hline & Shanghai No.1 Machine Tool Works Co., Ltd & China \\
\hline & Toshiba Corporation & Japan \\
\hline & Mitsubishi Heavy Industries, Ltd. & Japan \\
\hline \multirow[t]{6}{*}{ Control Rod Drive Mechanisms } & Westinghouse Electric Company, Newington Plant & U.S. \\
\hline & Shanghai No.1 Machine Tool Works Co., Ltd & China \\
\hline & Toshiba Corporation & Japan \\
\hline & Curtiss-Wright EMD & U.S. \\
\hline & AREVA - Jeumont & France \\
\hline & Mitsubishi Heavy Industries, Ltd. & Japan \\
\hline \multirow[t]{5}{*}{ Reactor Coolant Pumps } & Curtiss-Wright EMD & U.S. \\
\hline & Shengyang Blower Works & China \\
\hline & KSB Group & Germany \\
\hline & AREVA - Jeumont & France \\
\hline & Mitsubishi Heavy Industries, Ltd. & Japan \\
\hline Variable Frequency Drives (Reactor Coolant Pumps) & Siemens Energy \& Automation & U.S. \\
\hline Containment Polar Crane & NuCrane (PaR, Westinghouse Electric Company, LLC) & U.S. \\
\hline 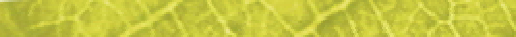 & DHI.DCW Group Co., Ltd. & China \\
\hline 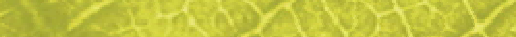 & Taiyuan Heavy Industry Co., Ltd & China \\
\hline
\end{tabular}

Notes: (1) Other suppliers probably available, e.g., Rus UK, Czech Republic 


\section{Nuclear Component Costs (Percentage of Total Equipment Cost)}

Component ${ }^{1}$

Major Components

Turbine Generator \& Auxiliaries 16 Instrumentation \& Controls Sys. 14 Large Valves (e.g., safety, dump) Containment

Cranes and Handling Equip. Safety Pumps Electrical Equip. (e.g., transforms) Miscellaneous Equip. Total

$$
\frac{\%}{35}
$$

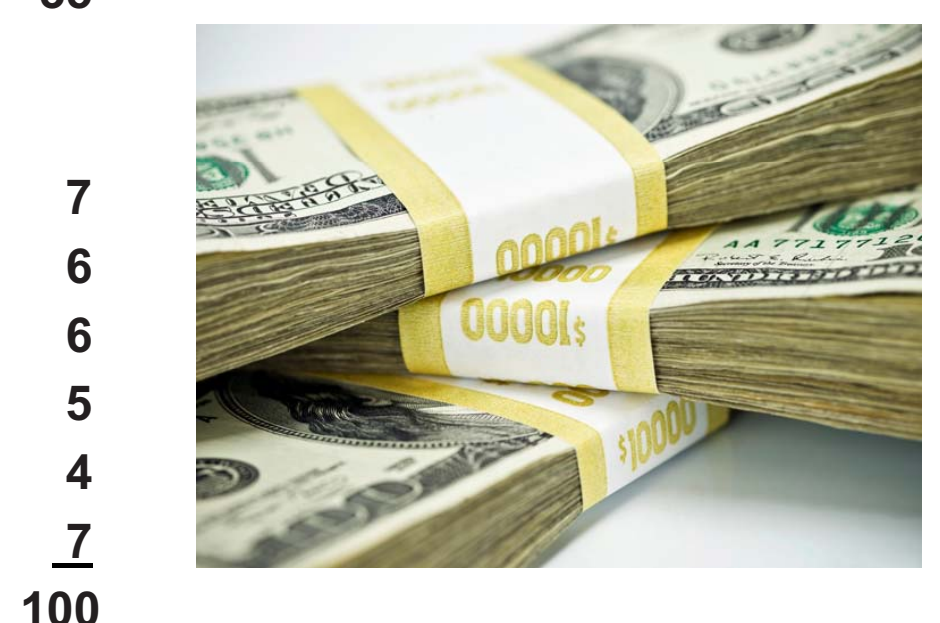

Notes: (1) Representative cost distribution - depends on specific designs and suppliers 


\section{Commodities are Large for New NPPs}

- Commodities of steel, concrete, piping, and cabling are large for modern nuclear plants

- If the nuclear renaissance takes off as anticipated and the economies of the world recover from the recent recession, shortages of construction commodities may become a limiting factor

\begin{tabular}{|l|r|l|}
\hline \multicolumn{3}{|c|}{ Commodity Estimates, One Unit } \\
\hline \multicolumn{1}{|c|}{ Commodity } & Amount & Units \\
\hline Concrete & 93,670 & cubic yards \\
\hline Rebar & 12,932 & tons \\
\hline Structural Steel & 8,826 & tons \\
\hline Power Cable & 774,180 & linear feet \\
\hline Small Bore Pipe & 122,262 & linear feet \\
\hline Large Bore Pipe & 111,546 & linear feet \\
\hline
\end{tabular}




\section{Transportation of Heavy and Specialized Nuclear Components}

- Heavy nuclear components require special handling

- Port access to the plant site reduces logistic issues

- Special transportation routing studies are required for rail or crawler shipment

- Steam generators are the most limiting because of their size and weight; then comes the RPV

- Other components typically can use traditional truck or rail

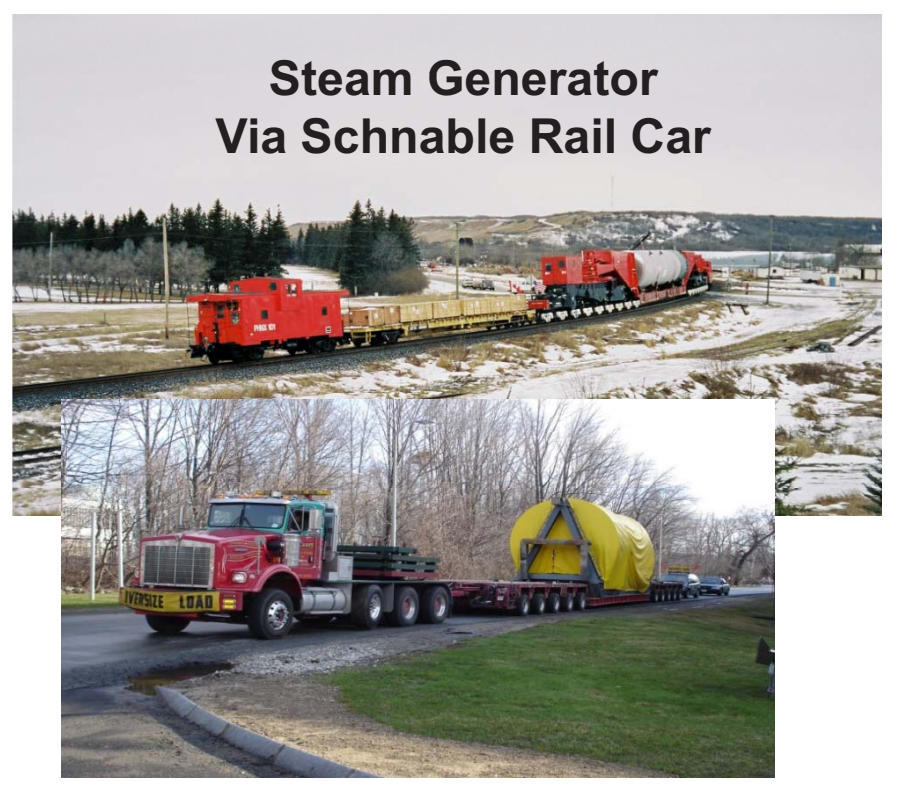
transportation 


\section{Heavy Lift Cranes (Lampson) Used Extensively}

- Heavy lift cranes used to set large structural modules (up to 800 tonnes)

- Used to set heavy nuclear components (e.g., RPVs and SGs which can also be up to 800 tonnes)

- Used to set containment shell sections and rebar modules

- Over-the-top placement of these heavy pieces by such cranes reduces construction schedule and other rigging requirements

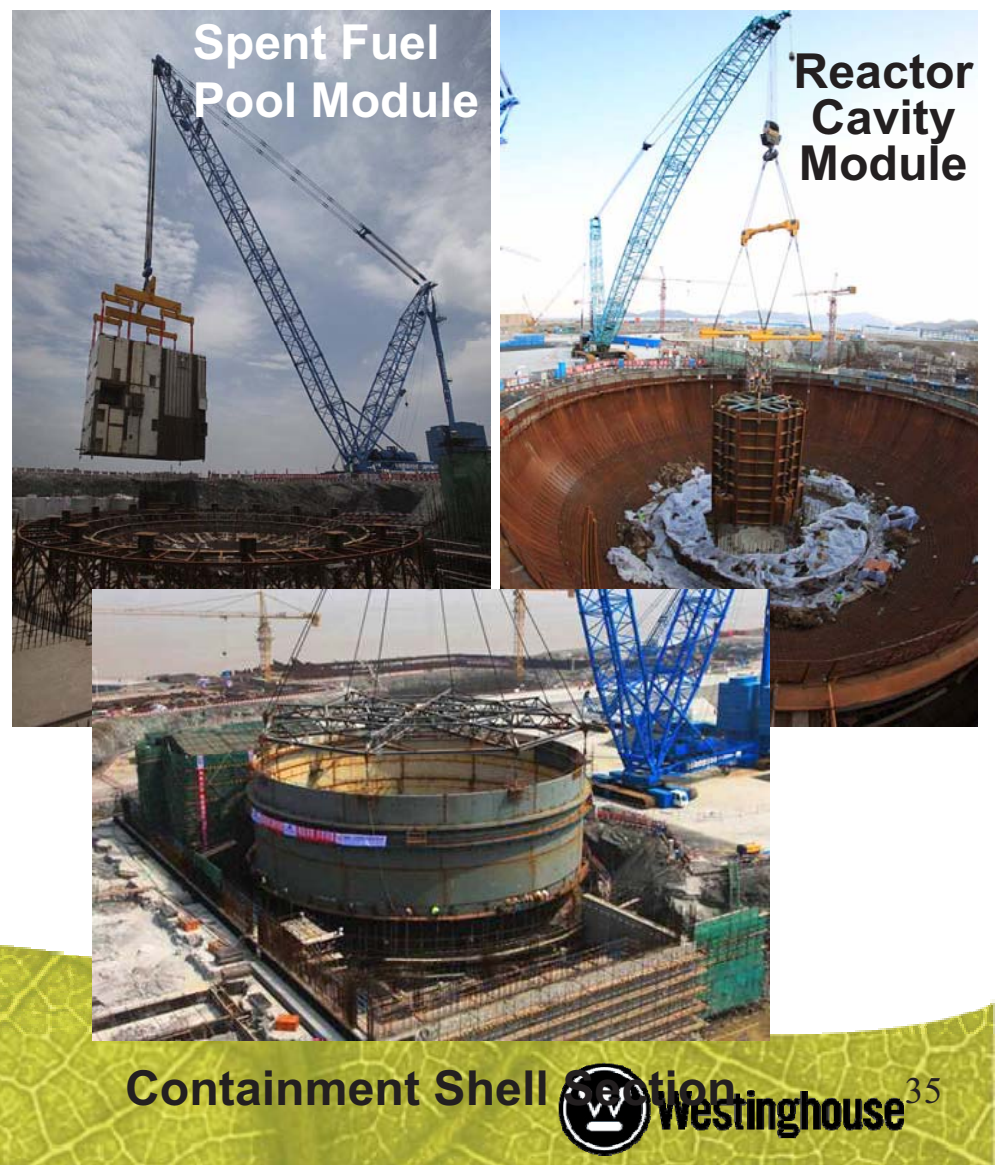




\section{Module Manufacturing}

- Ever increasing modular construction is a reality for future new plants

- Additional module manufacturing shops are needed for new plant construction

- Major construction modules alone for AP1000 plant constitute over 2,100 tons of steel

- Shaw Group recently built a shop for new nuclear plants in U.S. and Europe

- Chinese built a module shop for their domestic projects
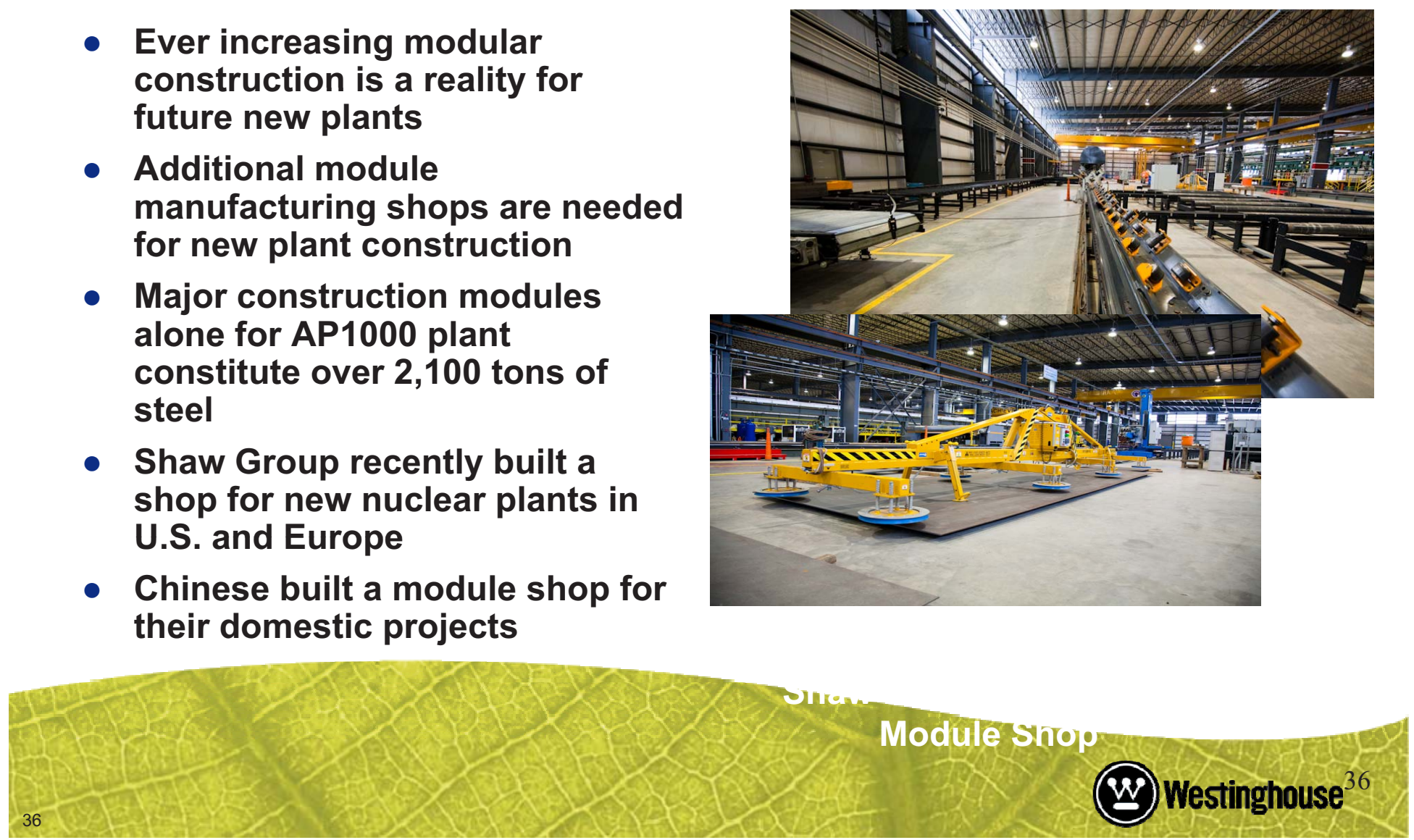


\section{People Challenges (nuclear experienced)}

- Project managers

- Construction managers

- Nuclear systems engineers

- Quality inspectors to oversee key manufacturers and sub-suppliers

- Supply management specialists

- Transportation and Logistics specialists

- Startup engineers

- Etc.

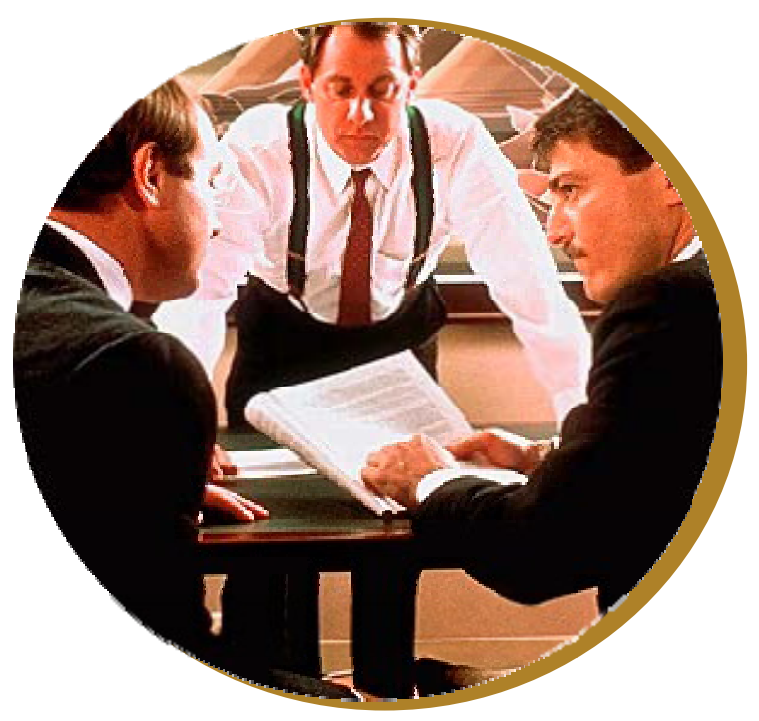




\section{Regulatory Authority Challenges (with new plant licensing experience)}

- Limited resources to evaluate and license new designs

- Different regulatory frameworks and regulations which can not necessarily be combined in a productive manner

- Need to take advantage of other safety authority reviews by sharing

- Submitted documentation

- Questions and answers

- Safety evaluation reports

- Share lessons learned and utilize high quality and transparent standards - helps foster strong safety culture

- Consider participation in the Multi-national Design Evaluation Program (MDEP) when 3 or more countries are interested in licensing the same standard design 


\section{Current Capabilities versus Requirements (annual values)}

Infrastructure

\section{Capability Requirement $\Delta$}

Uranium Supply (tHM)

Conversion (tHM)

Enrichment (x1000kg SWU)

Fuel Fabrication (tHM)

Heavy Forgings (No. NPPs)

Heavy Component (No. NPPs)

SG Tubing (No. NPPs)
68,600

$63,090^{1}$

56,200

14,250

20.5

34

9
$66,500+$

$61,000+$

$56,000+$

$9,980+$

$15^{2}+$

$15^{2}+$

$15^{2} ?$

Notes: (1) Additional $\sim 20,000$ tHM conversion equivalent capacity available from other uranium sources

(2) Based on $\sim 58$ reactors currently under construction worldwide with assumed 4 year construction schedules

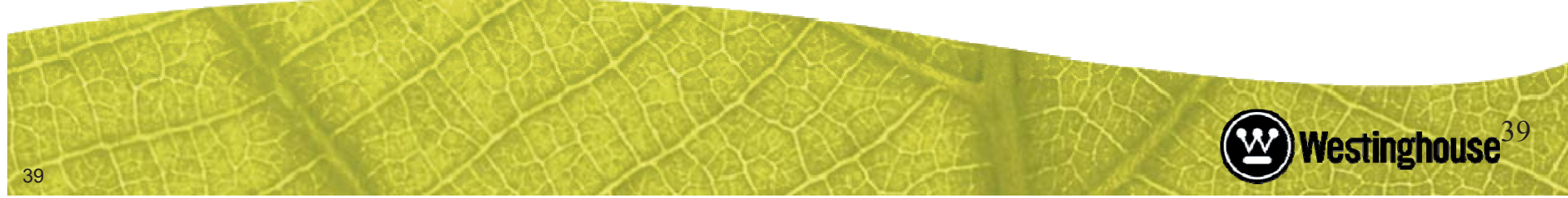




\section{Summary and Conclusions}

- Impact on nuclear infrastructure from nuclear renaissance may not be where people have expected it to be because of recent expansions

- Appears to be adequate forging capacity in the future

- Appears to be adequate heavy component manufacturing capacity

- There is plenty of uranium available for the next century, but mining capacity needs to expand from current levels

- Enrichment capacity is being added rapidly with potential near term over capacity

- Fuel manufacturing capacity will be able to supply new build if China and India localize this as stated in their plans

- Limitations may be on steam generator tubing if future expansion does not occur in this area

- Personnel limitations in specialized areas may put new nuclear build in jeopardy

- Capabilities of regulatory authorities could slow the renaissance from progressing as quickly as desired

- Transportation and construction equipment may become limiting depending on the reactor site

- Module fabrication capacity will need to be expanded locally where significant new plant construction is being conducted 


\section{Attachment 2}

\section{Infrastructure Readiness Assessment for the NGNP, AREVA, Document Number: 12-9142633-02}




\title{
AREVA
}

\section{AREVA NP Inc.}

\author{
Technical Data Record
}

Document No.: $\quad 12-9142633-002$

\section{Infrastructure Readiness Assessment for the NGNP}

\section{Disclaimer}

This report was prepared as an account of work sponsored by an agency of the United States Government. Neither the United States Government nor any agency thereof, nor any of their employees, nor their contractors and subcontractors, makes any warranty, express or implied, or assumes any legal liability or responsibility for the accuracy, completeness, or usefulness of any information, apparatus, product, or process disclosed, or represents that its use would not infringe privately owned rights. Reference herein to any specific commercial product, process, or service by trade name, trademark, manufacturer, or otherwise does not necessarily constitute or imply its endorsement, recommendation, or favoring by the United States Government or any agency thereof. The views and opinions of authors expressed herein do not necessarily state or reflect those of the United States Government or any agency thereof.

\section{BEA Contract No. 00075310}


Safety Related? $\square$ YES $\$ NO

Does this document contain assumptions requiring verification? $\square$ YES $\quad$ NO

Does this document contain Customer Required Format? $\square$ yES $\square$ No

\section{Signature Block}

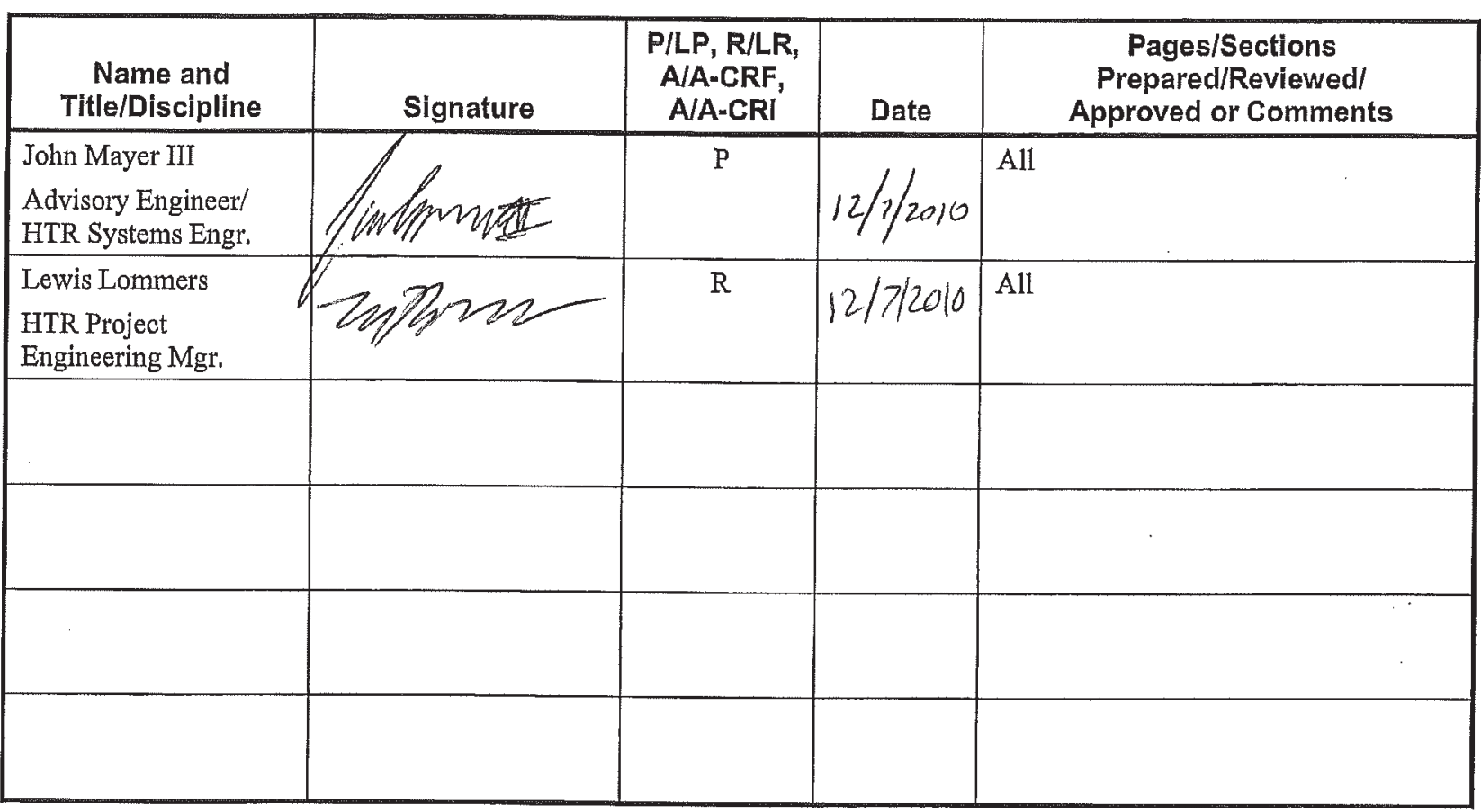

Note: $\quad$ P/LP designates Preparer (P), Lead Preparer (LP)

R/LR designates Reviewer (R), Lead Reviewer (LR)

A/A-CRF designates Approver (A), Approver of Customer Requested Format (A-CRF)

A/A-CRI designates Approver (A), Approver - Confirming Reviewer Independence (A-CRI) 
Infrastructure Readiness Assessment for the NGNP

\section{Record of Revision}

\begin{tabular}{|l|l|l|}
\hline $\begin{array}{c}\text { Revision } \\
\text { No. }\end{array}$ & \multicolumn{1}{|c|}{$\begin{array}{c}\text { Pages/Sections/ } \\
\text { Paragraphs Changed }\end{array}$} & \multicolumn{1}{c|}{ Brief Description / Change Authorization } \\
\hline 000 & All & Initial issue \\
\hline 001 & All & $\begin{array}{l}\text { Update of most report sections. Key changes include incorporation of INL } \\
\text { comments, verification of preliminary information, incorporation of key } \\
\text { reference data, and addition of Section 6, Infrastructure Readiness Summary } \\
\text { Table. }\end{array}$ \\
\hline 002 & Table of Acronyms & Added Table of acronyms \\
\hline 002 & Section 1.2 & Deleted Section \\
\hline 002 & Appendix A & Moved previous Section 4.3.1 into Appendix A \\
\hline 002 & Various & Addressed minor comments from INL. \\
\hline & & \\
\hline & & \\
\hline & & \\
\hline & & \\
\hline & & \\
\hline & & \\
\hline
\end{tabular}




\section{Table of Contents}

Page

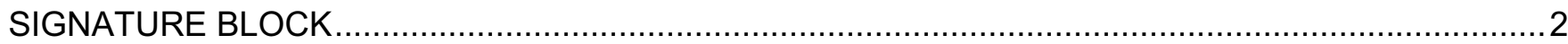

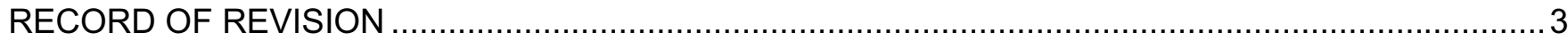

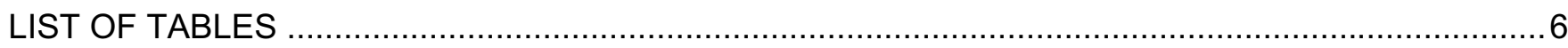

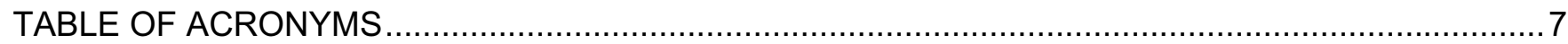

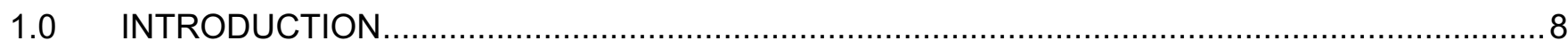

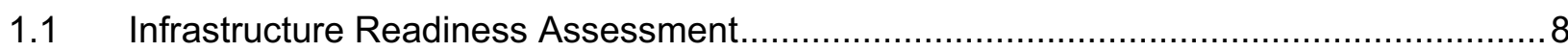

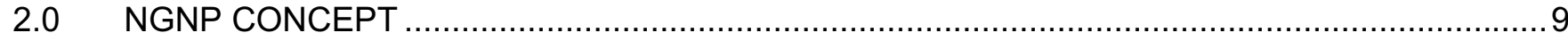

3.0 CONSIDERATIONS FOR INFRASTRUCTURE ASSESSMENT .................................... 12

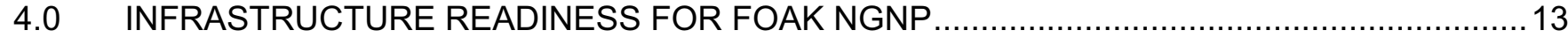

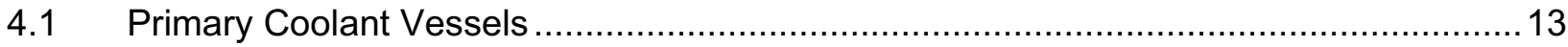

4.1.1 Ability to Provide Vessel Components ................................................. 13

4.1.2 Ability to Meet QA and ASME Code Requirements for Vessels ..................14

4.1.3 Capability to Transport Vessel Components............................................ 14

4.1.4 Workforce Readiness for Vessel Production ........................................ 15

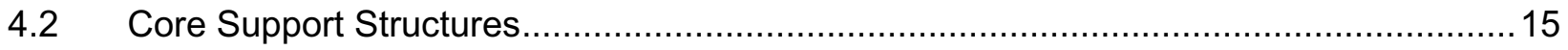

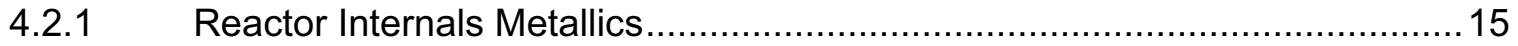

4.2.2 Reactor Internals Ceramic Composites ............................................. 15

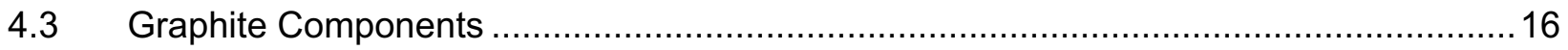

4.3.1 Graphite Vendor Questions ....................................................... 17

4.3.2 Graphite Vendor Summary ...................................................... 17

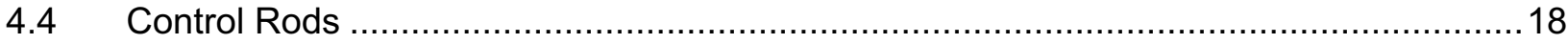

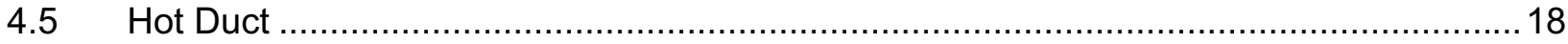

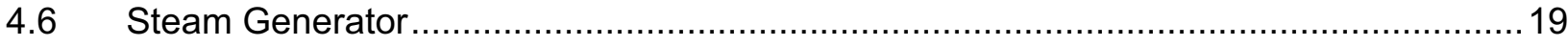

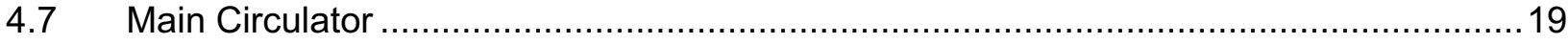

4.8 Auxiliary Cooling System Heat Exchanger .......................................................... 20

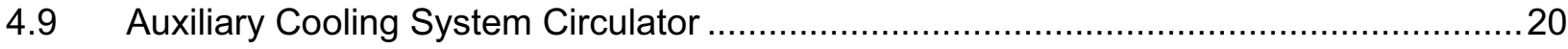

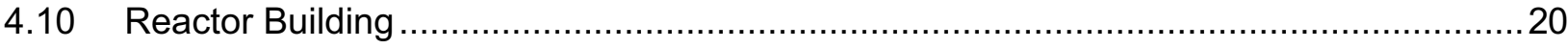

4.10.1 Infrastructure Readiness and High Temperature Concrete ......................20

4.10.2 Infrastructure Readiness and Impact of Building Embedment ....................21 
Infrastructure Readiness Assessment for the NGNP

\section{Table of Contents}

(continued)

Page

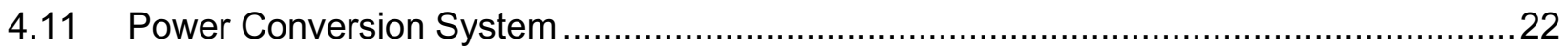

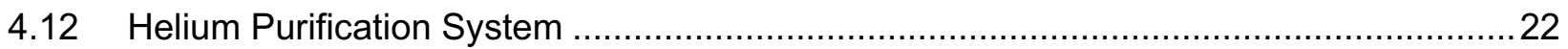

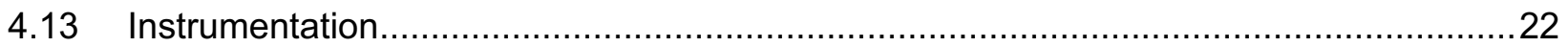

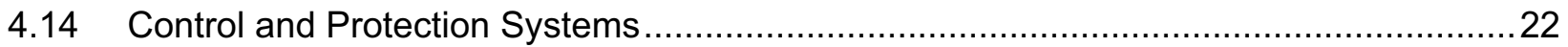

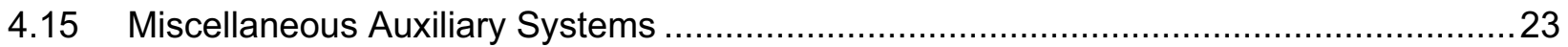

4.16 Generic Nuclear Power Infrastructure ...............................................................23

$5.0 \quad$ INFRASTRUCTURE READINESS FOR FOLLOW-ON HTGRS .....................................24

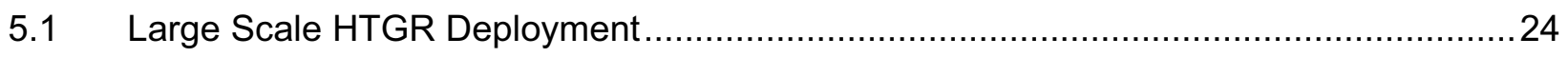

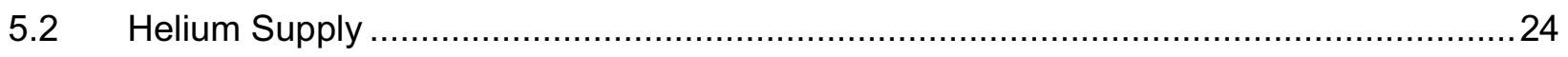

5.2.1 Background - World Helium Resources ............................................... 25

5.2.2 Availability of Helium to Support Future HTR Operations .............................25

5.2.3 Helium Requirements for HTR Deployment....................................... 26

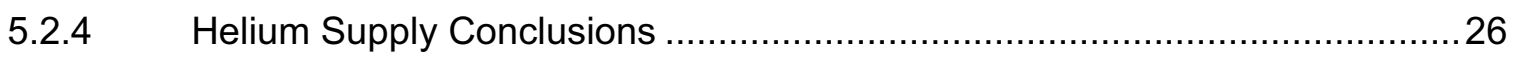

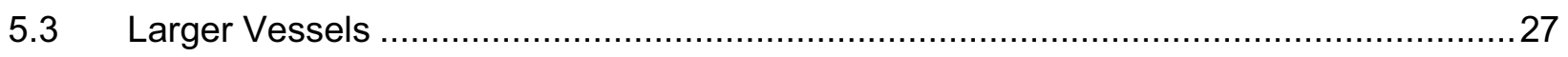

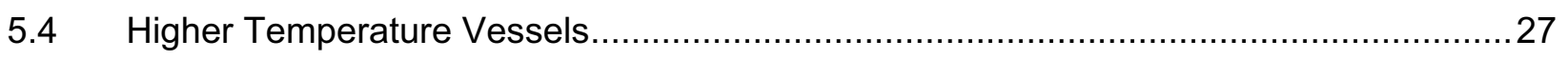

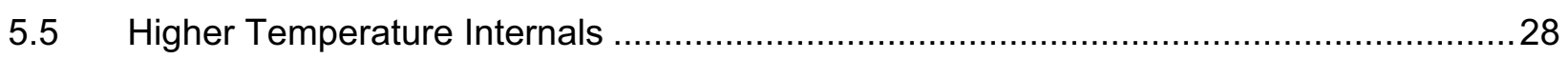

5.5.1 Core Support Structures for Higher Temperature NOAK HTGRs ..................28

5.5.2 Hot Duct for Higher Temperature NOAK HTGRs ...................................... 29

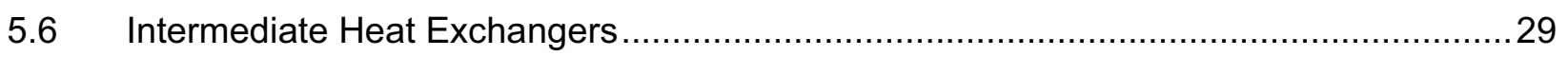

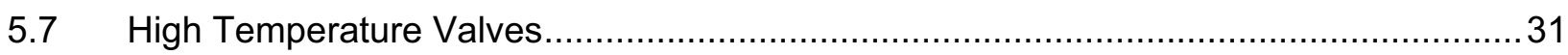

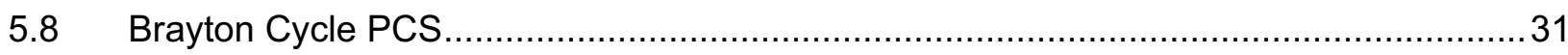

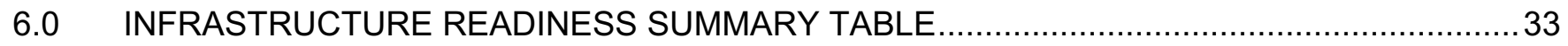

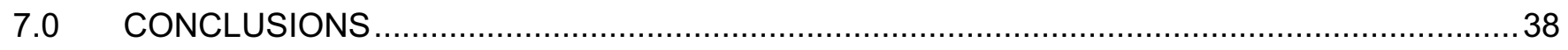

7.1 Summary of Current Infrastructure Readiness ................................................ 38

7.2 Summary of Infrastructure Readiness for Follow-On NOAK Plants ............................39

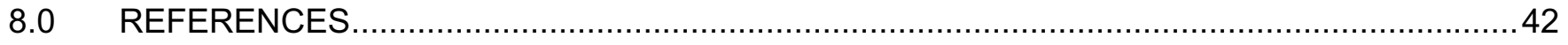




\section{List of Tables}

\section{Page}

TABLE 2-1: PLANT CHARACTERISTICS FOR INFRASTRUCTURE ASSESSMENT .......................9

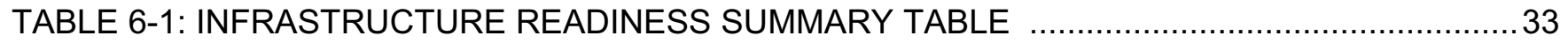




\section{Table of Acronyms}

$\begin{array}{ll}\text { AGC } & \text { Advanced Graphite Capsule } \\ \text { AGR } & \text { Advanced Gas-cooled Reactor } \\ \text { BLM } & \text { Bureau of Land Management } \\ \text { BNFL } & \text { British Nuclear Fuels LTD. } \\ \text { DOE } & \text { Department of Energy } \\ \text { FOAK } & \text { first-of-a-kind } \\ \text { HTGR } & \text { High Temperature Gas-cooled Reactor } \\ \text { HTTR } & \text { High Temperature engineering Test Reactor } \\ \text { IHX } & \text { Intermediate Heat Exchanger } \\ \text { INET } & \text { Institute of Nuclear and new Energy Technology } \\ \text { ITER } & \text { International Thermo-nuclear Experimental Reactor } \\ \text { JSW } & \text { Japan Steel Works } \\ \text { LWR } & \text { Light Water Reactor } \\ \text { MHTGR } & \text { Modular High Temperature Gas-cooled Reactor } \\ \text { MT } & \text { metric ton } \\ \text { NEAC } & \text { Nuclear Energy Advisory Committee } \\ \text { NGNP } & \text { Next Generation Nuclear Plant } \\ \text { NOAK } & \text { Nth-of-a-kind } \\ \text { NRC } & \text { Nuclear Regulatory Commission } \\ \text { ODS } & \text { oxide dispersion strengthened (metals) } \\ \text { QA } & \text { quality assurance } \\ \text { RCCS } & \text { Reactor Cavity Cooling System } \\ \text { TBD } & \text { To be Determined } \\ \text { THTR } & \text { Thorium Hochtemperatur Reaktor } \\ \text { TRISO } & \text { Tristructural-isotropic } \\ \end{array}$




\subsection{INTRODUCTION}

The U.S. Department of Energy (DOE) Next Generation Nuclear Plant (NGNP) project supports the development, demonstration, and deployment of high temperature gas-cooled reactor (HTGR) technology. The HTGR has the potential for high efficiency electricity production and the supply of high temperature process heat. The NGNP project includes a variety of activities such as fuel development and qualification, materials R\&D, design, licensing, and potentially demonstration.

NGNP project Phase 1 activities are currently being performed. At the conclusion of NGNP Phase 1, a review of the project will be performed by the Nuclear Energy Advisory Committee before proceeding with NGNP project Phase 2 (design, licensing, and demonstration). This report is intended to provide one input to that review.

\section{$1.1 \quad$ Infrastructure Readiness Assessment}

This report presents an assessment of the infrastructure readiness for NGNP deployment. The assessment is independent of the reactor technology deployed, that is, it does not assume a particular reactor design (prismatic or pebble) as a basis.

In general, the infrastructure readiness assessment examines the current state and plans to address the various infrastructure elements necessary to support deployment of the NGNP. The focus is on industrial capabilities as opposed to laboratory infrastructure or capabilities. It concentrates on the actual infrastructure for construction and start of operations for an NGNP, with an understanding that the same infrastructure could be brought to bear on follow-on HTGR deployment.

Hence, one primary focus is on the adequacy of the infrastructure necessary for near-term deployment of the initial NGNP demonstration plant. However, consideration is also given to the broader infrastructure needed for commercial deployment of a fleet of HTGRs including future more advanced concepts.

Design readiness is not covered in this infrastructure assessment. Design readiness is a serious question and a factor that touches every other aspect of this and other assessments. For example, it is difficult to assess the adequacy of the industrial infrastructure to supply NGNP components when the details of those components are undefined. Nonetheless, the assessments must be made using available information in order to manage risk successfully while allowing the project to move forward in a timely fashion.

This is an infrastructure readiness assessment, not a technology maturity assessment. This assessment assumes that the basic underlying technology is adequately developed. The assessment of technical maturity has been the direct focus of past studies and may be evaluated again outside this assessment. Nonetheless, additional implementation development may be necessary in some cases to industrialize specific technologies.

Fuel supply for the NGNP is not addressed in this assessment. The DOE Advanced Gas-cooled Reactor (AGR) program is facilitating the development and qualification of tristructural-isotropic (TRISO) particle fuel. Industrialization of fuel supply for the NGNP will be required. Industrialization of the fuel supply is a key issue for NGNP and further HTGR deployment, but it is not addressed in this assessment. It will be evaluated elsewhere.

Licensing readiness is also not addressed in this assessment. Licensing is evaluated elsewhere. 


\section{$2.0 \quad$ NGNP CONCEPT}

The near-term NGNP concept considered in this assessment is a steam cycle HTGR with a reactor outlet temperature in the range of $750-800^{\circ} \mathrm{C}$. The steam generator is located directly in the primary circuit, maximizing thermal performance and eliminating the need for an intermediate heat exchanger and secondary gas loop. This concept will likely be the first-of-a-kind (FOAK) design built as the initial NGNP demonstration plant. Key characteristics of the FOAK concept are shown in the second column of Table 2-1.

This assessment also considers the readiness of the industrial infrastructure for follow-on deployment of a fleet of HTGRs. Such a fleet would be assumed to include Nth-of-a-kind (NOAK) copies of the initial FOAK plant as well as more advanced NOAK plants. The follow-on HTGRs might differ from the initial FOAK plant is several ways. First, the reactors might simply be larger both in output and physical size. More importantly, they would probably serve a variety of applications beyond simple high temperature steam. These could include direct process heat (with an intermediate heat exchanger and a secondary heat transfer loop using gas or molten salt). They could also include electricity production with a direct Brayton cycle or a combined cycle gas turbine.

The burden of this subsequent fleet of plants on the industrial infrastructure would be greater than the first plant due to the following factors:

- Large number of plants

- Larger components

- Higher temperature materials

- Different components (e.g., IHX, gas turbine, etc.)

Some sample characteristics of the potential NOAK plants are shown in the third column of Table 2-1.

Table 2-1: Plant characteristics for infrastructure assessment

\begin{tabular}{lll}
\hline & \multicolumn{1}{c}{ FOAK } & \multicolumn{1}{c}{ NOAK } \\
Power Level & $200-350 \mathrm{MWt}$ & $200-600 \mathrm{MWt}$ \\
Reactor Outlet Temp. & $750-800^{\circ} \mathrm{C}$ & $750-950^{\circ} \mathrm{C}$ \\
Reactor Inlet Temp. & $280-325^{\circ} \mathrm{C}$ & $280-500^{\circ} \mathrm{C}$ \\
Primary Fluid & $\mathrm{He}$ & $\mathrm{He}$ \\
Primary Pressure & $7-9 \mathrm{MPa}$ & $7-9 \mathrm{MPa}$ \\
Configuration & Single loop w/steam generator & Single or multiple loops with steam \\
& with cross duct & generator or IHX \\
Steam Generator Pressure & $17 \mathrm{MPa}$ & $17 \mathrm{MPa}$ \\
Pressure Vessel Material & SA 508/533 & SA 508/533 \\
& & SA 508/533 with active cooling \\
& & Mod 9Cr-1Mo (Grade 91) \\
\hline
\end{tabular}


Infrastructure Readiness Assessment for the NGNP

\begin{tabular}{|c|c|c|}
\hline & FOAK & NOAK \\
\hline \multirow[t]{6}{*}{ RPV Attributes } & Inside dia. $6.55 \mathrm{~m}$ & Inside dia.: $6.55-7.22 \mathrm{~m}$ \\
\hline & Wall thickness: & Wall Thickness: 133-216 mm \\
\hline & top: $133 \mathrm{~mm}$ & \\
\hline & bottom: $191 \mathrm{~mm}$ & \\
\hline & Height $22.5 \mathrm{~m}$ & Height: $22-30 \mathrm{~m}$ \\
\hline & Weight 810 tonnes & Weight: $728-1,328$ tonnes \\
\hline \multirow[t]{2}{*}{ Cross Vessel Dimensions } & Outside dia. $1.9 \mathrm{~m}$ & TBD \\
\hline & Wall thickness $50.7 \mathrm{~mm}$ & \\
\hline \multirow{6}{*}{$\begin{array}{l}\text { Steam Generator Vessel } \\
\text { Dimensions }\end{array}$} & Inside dia.: $4.36 \mathrm{~m}$ & TBD \\
\hline & Wall thickness: & \\
\hline & $140 \mathrm{~mm}$ & \\
\hline & Bottom: $95.3 \mathrm{~mm}$ & \\
\hline & Height: $28 \mathrm{~m}$ & \\
\hline & $\begin{array}{l}\text { Weight (w/o tube bundle): } \\
322 \text { tonnes }\end{array}$ & \\
\hline \multirow{3}{*}{ Steam Generator Materials } & $2-1 / 4 \mathrm{Cr}-1 \mathrm{Mo}$ & $2-1 / 4 \mathrm{Cr}-1 \mathrm{Mo}$ \\
\hline & Alloy $800 \mathrm{H}$ & Alloy $800 \mathrm{H}$ \\
\hline & & Inconel 617 \\
\hline IHX Design & NA & Compact or shell and tube \\
\hline \multirow[t]{3}{*}{ IHX Materials } & NA & Inconel 617 \\
\hline & & Hastelloy X \\
\hline & & Hastelloy XR \\
\hline No. of Loops & 1 & 1-3 Loops \\
\hline Main Circulator & 3.6 MWe & $\begin{array}{l}4-12 \mathrm{MWe} \text { (depending on \# of } \\
\text { loops) }\end{array}$ \\
\hline \multirow[t]{3}{*}{ Core Barrel Material } & $800 \mathrm{H}$ & $800 \mathrm{H}$ \\
\hline & $316 \mathrm{H}$ & $316 \mathrm{H}$ \\
\hline & $21 / 4 \mathrm{Cr}-1 \mathrm{Mo}$ & Grade 91 \\
\hline \multirow[t]{6}{*}{ Graphite Material } & NGB-18 & NGB-18 \\
\hline & PCEA & PCEA \\
\hline & NGB-17 & NGB-17 \\
\hline & IG-110 & IG-110 \\
\hline & 2110 & 2110 \\
\hline & & Advanced graphites \\
\hline High Temp Valves & N/A & TBD \\
\hline
\end{tabular}


Infrastructure Readiness Assessment for the NGNP

\begin{tabular}{|c|c|c|}
\hline & FOAK & NOAK \\
\hline \multirow{3}{*}{$\begin{array}{l}\text { Pressure Vessel Fabrication } \\
\text { Options }\end{array}$} & Rolled plate w/welds & Same as FOAK \\
\hline & Ring forgings & \\
\hline & Nozzle forgings & \\
\hline \multirow[t]{3}{*}{ PCS } & Rankine cycle steam plant & Rankine cycle steam plant \\
\hline & & Brayton cycle (direct) \\
\hline & & Combined cycle \\
\hline \multirow[t]{3}{*}{ Reactor Vessel Internals } & $800 \mathrm{H}$ & $800 \mathrm{H}$ \\
\hline & Hastelloy X/XR & Hastelloy X/XR \\
\hline & Composites & Composites \\
\hline Instrumentation and Control & Primary loop instrumentation & Primary loop instrumentation \\
\hline \multirow[t]{2}{*}{ Reactor Building } & High-temperature concrete & High-temperature concrete \\
\hline & Full or partial embedment & Full or partial embedment \\
\hline
\end{tabular}




\subsection{CONSIDERATIONS FOR INFRASTRUCTURE ASSESSMENT}

The industrial infrastructure must be prepared for NGNP deployment on three distinct levels:

- Technical readiness

- Industrial readiness
Does the required industrial technology exist? This is related to technology maturity, but it goes beyond the fundamental science. The primary question is whether or not the required processes have been adequately industrialized. For example, the welding process for a certain alloy may have been developed and optimized in the laboratory. But it is not industrialized until standard welding procedures and equipment have been developed and qualified on the shop floor.

Do the required facilities and supplies exist for industrial scale production? It is not enough to have the process defined. The required foundries, forges, shops, processing facilities, etc., must be available. The skilled labor must be available and trained as well. Similarly, qualified input materials and feedstocks to the production processes must also be available.

- Commercial readiness Is it commercially attractive enough for industry to support NGNP deployment? Even if the process and facilities exist, it might still be difficult to support NGNP deployment if those facilities are committed to other existing or more profitable business.

Specific topics to be addressed include:

A. Ability to provide components

B. Ability to meet quality assurance (QA) requirements

C. Capability to transport components

D. Workforce readiness

E. Construction capabilities

These topics must be addressed for both the FOAK NGNP demonstration plant and for potential follow-on NOAK plants. Readiness for the FOAK plant will be dominated by technical readiness and basic industrial readiness. Industry's ability to support follow-on plants in the future will be dominated more by broader industrial readiness and commercial readiness. In most cases, finding the resources to support a single one of a kind plant can be worked out. However, supporting a potential fleet of follow-on plants requires a more significant commitment often involving expansion or major realignment of facilities and staff.

Where appropriate, consideration will also be given to changes or relaxation of NGNP design requirements that might alleviate potential infrastructure readiness challenges. 
Document No.: 12-9142633-002

Infrastructure Readiness Assessment for the NGNP

\subsection{INFRASTRUCTURE READINESS FOR FOAK NGNP}

The infrastructure readiness for deployment of the anticipated FOAK NGNP concept is assessed for each major component or system.

\subsection{Primary Coolant Vessels}

The primary system boundary for the FOAK NGNP is expected to be fabricated using conventional SA508/533 material. The vessels will be similar to conventional LWR vessels except that the NGNP vessel is expected to be larger in size and it is not expected to require internal cladding.

\subsubsection{Ability to Provide Vessel Components}

The industrial capability to produce the envisioned SA508/533 NGNP vessels currently exists. Though the envisioned vessel sizes are generally larger than LWR vessels, the wall thicknesses are less than or equal, ensuring that weld thicknesses are bound by previous experience.

The reactor vessel is most challenging due to its large size. References 2 and 3 provide a comprehensive review of the ability to fabricate key reactor vessel components, along with an examination of existing capabilities of both national and international suppliers. Reference 4 represents a vessel acquisition strategy developed by INL based on these review documents. Since the date of publication of these references, additional capacity has been added at the Saarschmiede GmbH Freiformschmiede plant. This plant was upgraded to supply all components of the Westinghouse AP1000 plant, including an upgraded forging press capacity of 12,000 tons and an estimated maximum ingot size of 330 tons. At this point it is not clear whether this plant will have the capacity to produce the largest NGNP forgings (the reactor vessel flange ring). Even without this capacity, however, the excess forging capacity at this facility should help alleviate schedule constraints at other forges. AREVA has also added to its manufacturing capacity in the US, through the development of the AREVA/Northrup Grumman facility in Newport News Virginia. This facility is designed to produce the heavy components for the EPR reactor. It has the capacity to produce components in excess of 500 tons and a throughput of the equivalent of 1 set of EPR components per year.

There are two fundamental parts of the vessel production process. First, forgings of the required material (and plates if needed) must be produced. Then a vessel fabricator assembles these pieces into a finished vessel.

There are multiple suppliers of SA508/533 forgings and plates. The most significant challenge is the ring forgings for the reactor vessel, especially the main vessel flanges due to ingot size and forging diameter. These large forgings would probably have to be produced by Japan Steel Works (JSW). JSW has the required processes and facilities to provide these forgings. However, the production capability is limited, and there is usually a significant backlog with production slots generally being reserved years ahead of time. At the present time, the backlog is substantial, although this is subject to change as the nature of the "nuclear renaissance" continues to evolve.

An important consideration is the number of ultra-heavy forgings required. If the reactor vessel is to be fabricated entirely from forgings, then several ultra-heavy forgings would be required. However, if the vessel is fabricated using plates, then perhaps only two or three ultra-heavy forgings would be required. In that case, smaller forgings required for nozzles, etc., could be provided by other forges. 
If the vessel is to be fabricated with forgings, it is questionable whether the required forgings could be procured in time to meet the current NGNP schedule. On the other hand, arrangements could possibly be made to obtain the limited number of ultra-heavy forgings required to support a plate vessel by negotiating adjustments in the existing production schedule at JSW. Major vendors such as AREVA do have some ability to shift or reallocate production slots to meet specific project needs. Obviously, this is easier, if the number of forgings involved is small.

There are multiple fabricators capable of producing the finished NGNP vessels once the required forgings have been procured. This fabrication also affects the project schedule, but the bottleneck is not as severe as for the forgings. Current fabricators predominantly build nuclear vessels using forgings, but the capability to build the vessels using plate is also available and has been accepted by regulators. Some nuclear reactor vessels are still built from plate. Forgings are preferred because they significantly reduce the required labor and inspection, but either process can provide an acceptable vessel.

In summary, the industrial technology and required facilities to produce the NGNP primary vessels are established. However, these facilities have limited capacity and are seeing significant demand. Therefore, commercial readiness is a challenge. Steps must be taken to minimize the risk to the project schedule. The longer this is delayed the more significant the risk, and the fewer options that will be available.

\subsubsection{Ability to Meet QA and ASME Code Requirements for Vessels}

The current infrastructure does not pose any significant challenges to meeting the quality assurance or ASME code requirements for the primary coolant vessels. The current infrastructure addresses these same requirements for current LWRs. It is expected that critical reactor vessel parameters, such as vessel material and weld thicknesses, will remain within the experience base defined by the currently supplied LWR vessels.

\subsubsection{Capability to Transport Vessel Components}

Depending on the location of the NGNP, delivery of the vessel components to the plant site may pose a challenge due to the size of the reactor vessel. Delivery to coastal sites or sites near navigable waterways is feasible using the current infrastructure. However, delivery to inland sites requiring long distance transport by rail or roadway is probably not feasible for the reactor vessel.

For inland sites, completion of reactor vessel fabrication at the NGNP site provides an alternative to delivery of the intact vessel. Such action is certainly feasible. Similar activities are currently employed in support of the replacement steam generator market. However, it would require the duplication of significant vessel fabrication facilities at the reactor site. This would result in additional cost and potential delay for the project.

For most future commercial sites, heavy component delivery is not believed to be an insurmountable problem, since navigable waterways are in reasonable proximity to most industrial regions. For example, location of the NGNP demonstration plant on the gulf coast of Texas would minimize this concern.

Delivery of major components is an important consideration in the site selection process for any reactor, including the NGNP. Ultimately a detailed transportation study will be required. Transportability is determined by various factors including dimensions, weight, shape, environment, packaging, etc. It is always site dependent. 


\subsubsection{Workforce Readiness for Vessel Production}

Skilled workers are required to staff the industrial facilities in which heavy components such as nuclear reactor vessels are manufactured. The existing pool of workers is adequate for the current production facilities. Moreover, additional workers will be trained for the new facilities now being developed or planned for the future. This is the same challenge being dealt with in current LWR projects.

There are no reasonable modifications to current NGNP requirements that would further mitigate the schedule challenges associated with vessel fabrication. These challenges are similar to those faced by LWR projects planned for the near future.

\subsection{Core Support Structures}

The core support structures considered here are the metallic structural components which surround and support the graphite core structures and reflectors as well as the graphite reactor outlet plenum. These include the metallic core support structures beneath the core, the core barrel which provides lateral support, the upper core restraint structures which maintain alignment of the upper core graphite structures in the prismatic reactor design, and the lateral restraint straps and tie rod assemblies in the pebble bed reactor design.

\subsubsection{Reactor Internals Metallics}

Historically alloy $800 \mathrm{H}$ has been used in HTGRs for these structures both in past operating HTGRs as well as HTGR design programs such as the MHTGR and the HTR-Module. A variety of other alloys are also currently being considered by NGNP designers including 316H, 21/4 Cr - 1Mo, Grade 91, Hastelloy X, and Hastelloy XR. In addition, ceramic composites are being considered for some components, particularly the upper core restraint structures.

All of these alloys (except Hastelloy XR as noted below) are widely available in industry. There is substantial industrial experience in producing components from these alloys. For example, they are used extensively in the petrochemical industry. However, their use in the nuclear industry has been limited. So the overall infrastructure for these components should be adequate, but some adjustment to produce nuclear components may be required. Either current fabricators working with these materials will have to institute procedures and quality programs to meet nuclear industry requirements (as applicable to the specific component being fabricated), or current nuclear component fabricators will have to expand their use of these materials. Both of these approaches are feasible and able to meet the requirements of the NGNP project given reasonable planning and preparation.

The one exception to the above is Hastelloy XR. This alloy has seen limited use in the nuclear industry in Japan. Most vendors do not have familiarity with this material and the current experience base is proprietary.

Nonetheless, the current infrastructure for this alloy is believed to be adequate, assuming that an existing Hastelloy XR vendor is selected as the component supplier. Otherwise, significant collaboration with an existing vendor would have to be arranged in order to develop new vendor capabilities.

\subsubsection{Reactor Internals Ceramic Composites}

Ceramic composites as discussed herein (and sometime referred to as simply "composites") include both carbon/carbon (C/C) composites (i.e. carbon fibers in a carbonaceous matrix) and $\mathrm{SiC} / \mathrm{SiC}$ composites (i.e., $\mathrm{SiC}$ fibers in a $\mathrm{SiC}$ matrix). Ceramic composites are being considered as alternatives to the above alloys for some reactor internals components such as the upper core restraint structures, lateral restraints and tie rods. These 
structures would offer significantly increased tolerance of off-design temperature excursions. References 5,6 , and 7 document previous NGNP composite material studies. These studies detail the advantages and disadvantages of the use of composites, along with reviews of existing vendor capabilities in these areas.

A substantial industrial infrastructure exists for composite materials and components including C-C composites, particularly in the aerospace industry. However, there is little experience with these composites in the nuclear industry.

Composite materials have fundamentally different characteristics than metallics. As a result, the design, fabrication, and qualification of composite components are different than metallic nuclear components.

The existing infrastructure for composite fabrication should be adequate to produce the required composite components.

However, the qualification of these components for use in the NGNP poses a fundamental challenge which has yet to be resolved. Once a qualification strategy is developed, decisions will have to be made how and where in the industrial infrastructure the strategy is to be implemented. The timeliest approach would probably be to adjust the quality programs at an existing composite fabricator, but developing the composite fabrication infrastructure at the reactor vendor could also be considered.

Clearly the infrastructure for composite components is not as mature as for metallic components. Even though composites offer the potential for enhanced performance and potentially increased design margins, design alternatives which minimize their use will maximize project readiness. For example, metallic upper core restraint elements may be preferred, even if their replacement is required following an accident. In some cases, a compromise approach may be best in which a component includes composites only where most beneficial and composite geometries are simplified in order to minimize any fabrication or qualification challenges.

To the extent that composites are still desirable, careful planning and preparation will be required to ensure the readiness of the supporting infrastructure.

\subsection{Graphite Components}

There are three basic types of graphite components in any HTGR - fuel elements, reflectors, and core support structures. While the details of each of these components will depend on the specific NGNP design selected, all will require graphite of high purity with stable properties.

Due to its favorable properties, graphite has been produced for nuclear reactors since the beginning of the nuclear age. The technology and infrastructure for production of nuclear grade graphite has improved significantly over the past 60 years. Today, there are only a few graphite suppliers actively considered as suppliers by potential NGNP reactor vendors: GrafTech, SGL Group, Toyo Tanso, and Carbone Lorraine (Mersen).

Graphite properties and graphite component performance are determined by both the feedstocks used in the graphite and the graphite production process. Graphites used in previous HTGRs in the US cannot be produced today, because the feedstock is no longer available. However, using current processes, the current graphite vendors have available newer graphite grades with comparable properties. The DOE Advanced Graphite Capsule (AGC) program, the aim of which is to identify and qualify reliably available graphite materials in support of HTGR development activities, is currently working with the graphite vendors to support characterization and qualification of these graphite grades. References 8 and 9 provide some detail as to the graphite selection strategies of this program as well as some initial irradiation test plans. 
The required quantity of graphite for the FOAK NGNP is small compared to the total production volume of any of the graphite vendors. However, the nuclear graphite specifications require production steps that have much more limited capacities. The existing infrastructure is believed to be adequate to produce the quantity of the selected grade of nuclear graphite on the planned NGNP production schedule. However, this assumes that the required quantity of graphite is ordered in a timely manner.

Graphite machining capability must also be considered in assessing the industrial infrastructure. All of the graphite parts to go into the NGNP must be machined. The specific machining requirements cannot be determined until the detailed core design geometry is established. It is clear that some specialized machining may be required. Again, this is not expected to be a problem for the FOAK NGNP schedule, provided that adequate lead time is included in the NGNP procurement process.

These graphite vendors are experienced at producing graphite for nuclear applications. They understand and are able to meet the quality requirements for nuclear components.

Vendors are able to control the properties of the finished product by controlling the feedstocks used and maintaining appropriate process controls. They are experienced at keeping properties within the expected specifications and impurities below their limits.

All graphite has some variability in properties. The key requirement is to understand the variability and to set appropriate requirements to bound the variability. Then the reactor vendors can design components for the specified variability, while vendors ensure that the actual variability is within the specification. While the variability of a material such as graphite may be larger than some more common materials, this fundamental nature of the design process is not that different.

\subsubsection{Graphite Vendor Questions}

Given the central nature of graphite as both a structural material and reflector material for HTGR plants, and the unique nature of its required fabrication and qualification processes, direct contact was made with two vendors currently involved in production of graphite for various global HTGR uses. These vendors were asked a series of questions designed to help assess both the short-term and long-term issues surrounding assurance of a stable qualified supply. These two vendors were Toyo Tanso, through their Toyo Tanso USA office in Troutdale OR, and SGL Group, through their SGL Carbon GmbH group in Meitingen Germany. The questions asked and the answers received, are presented in Appendix A of this report.

\subsubsection{Graphite Vendor Summary}

Based on the interactions with these two graphite suppliers, coupled with the qualification activities being carried out by INL through the AGC program, it is concluded that supply of graphite for the initial NGNP plant should be within the capabilities of the existing graphite supply infrastructure. Key fabrication durations and required ordering lead times discussed in Appendix A also seem to be well within the required schedule constraints for deployment of the NGNP.

For the NOAK fleet, the potential exists to meet the demand, but it will require specific business arrangements to divert existing capacity or to add required capacity. Should expansion be required, it is not seen to be problematic given the right business environment. 


\subsection{Control Rods}

Two basic technologies are currently considered for the NGNP control rods. One approach uses segmented metallic rods similar to those used successfully in previous HTGRs (e.g., Fort St. Vrain). The other approach uses rods fabricated partially or entirely with ceramic materials.

The current infrastructure is adequate for the metallic rods. There is no question that reactor vendors could fabricate the metallic rods for use in the NGNP. They have significant experience fabricating components of similar complexity to nuclear QA requirements on a frequent basis.

The infrastructure for the ceramic rods is less well established. These rods would use $\mathrm{C}-\mathrm{C}$ or $\mathrm{SiC}-\mathrm{SiC}$ composites for some or all of the major structural elements of the rods. The infrastructure issues identified for the composite reactor internals components apply to these as well. Significant composite fabrication experience relevant to the control rods exists outside the nuclear industry. However, the infrastructure issues associated with $\mathrm{SiC}-\mathrm{SiC}$ are believed to be more significant than those of the $\mathrm{C}-\mathrm{C}$ composite material, since the overall industrial experience with $\mathrm{C}-\mathrm{C}$ is substantially greater. The control rod components have somewhat of an advantage in that they are generally smaller than the major reactor internals components. However, the control rods will see a significantly higher neutron fluence which must be taken into account as part of the qualification process.

The selection of advanced composite components within the control rods will require a clear path to confirm the required technology development and qualification process. While outside the scope of the industrial infrastructure assessment, there is nonetheless a clear relationship between the technology development and the implementing industrial infrastructure. As was the case for the composite reactor internals, to the extent that composites are still desirable, careful planning and preparation will be required to ensure the readiness of the supporting infrastructure.

It should be noted that control rods are replaceable components. Therefore, the path with least risk for near-term deployment may involve initial use of metallic rods at the beginning of plant life with future substitution of composite or hybrid metallic-composite rods for improved performance margins.

\subsection{Hot Duct}

The hot duct is a fabricated structure that includes a structural tube, internal insulation, and cover plates which keep the insulation in place. The structural tube also provides the pressure boundary between the hot reactor outlet gas and the cold reactor inlet gas. Hot duct designs also typically include one or more bellows to accommodate thermal expansion.

The main issue of consideration for the hot duct is the specification of the liner material. The liner is exposed to the hot reactor outlet gas. For the near-term FOAK NGNP concept, the reactor outlet temperature should be low enough to allow use of a metallic liner such as alloy $800 \mathrm{H}$.

In general, the hot duct is well within the capabilities of the current industrial infrastructure. The materials of fabrication are routine. The component sizes do not place any unreasonable demands on the infrastructure. Addressing fabricability issues during the design process will ensure that no unusual demands arise. 


\subsection{Steam Generator}

The technology for the FOAK NGNP steam generator is relatively mature. Similar technology was developed for earlier reactors, and actual steam generators have been built for Fort St. Vrain, Thorium Hochtemperatur Reaktor (THTR), and other past HTGRs.

However, the industrial processes to build a helical coil HTGR steam generator are complex. They involve bending and welding a large number of tubes in a relatively complex geometry which interacts with a radial support structure. While these components have been built in the past, the details of the processes are unique to the specific component design. This is the reason that past lists of development needs have identified fabrication $\mathrm{R} \& \mathrm{D}$ as a requirement to support steam generator fabrication. This development work includes such activities as building fabrication mockups and jigs, etc. Such work cannot be finalized until the detailed steam generator design is more mature.

Industry is familiar with the materials anticipated for the steam generator.

The current industrial infrastructure can provide the NGNP steam generator. However, it will be necessary to ensure that the project schedule is adequate to allow the required preproduction development activities.

Steam generator size is an important consideration for both manufacture and delivery of the steam generator. Current shop facilities are large enough to provide a steam generator in the 300-350 MWt range and probably larger.

The steam generator will be smaller than the reactor vessel, so delivery to most sites would not be a problem. However, sites without navigable water access will have to be assessed in detail. The completed steam generator is expected to be close to the limits of rail or roadway transportability. Whether or not the steam generator can be transported to a specific isolated site will depend on the specific design of the steam generator and the specific obstacles in the vicinity of the site. For most anticipated industrial sites, this will not be an issue.

\subsection{Main Circulator}

A main circulator of the size required for the near-term FOAK NGNP concept is within the capability of the current industrial infrastructure. Discussions have been held in the past with current and potential future circulator suppliers to review the feasibility of circulators in various size ranges. Circulators up to about $4 \mathrm{MWe}$ (and potentially up to $6 \mathrm{MWe}$ ) are within current capacity and could be contracted for today.

The required subsystems and components have been reviewed by the potential vendors including impeller and diffuser, bearings, motor, and power supplies. Current experience in each of these areas brackets the FOAK NGNP requirements. The facilities and processes within the current infrastructure are adequate to produce the required component. Reference 10 presents the results of detailed interactions with one prominent circulator vendor, Howden, related to the current state of readiness to supply circulators for HTGR reactors. These results are consistent with discussions that AREVA has held with this vendor outside of the frame of the NGNP program.

Potential circulator vendors are familiar with nuclear industry quality requirements.

Delivery and installation of the main circulator would not be a problem. 


\subsection{Auxiliary Cooling System Heat Exchanger}

The details of the auxiliary cooling system heat exchanger will depend on the specific design selected. However, some general characteristics are clear which allow an assessment of the infrastructure's readiness to supply this component.

The auxiliary heat exchanger will be considerably smaller than the steam generator. It will have a much smaller heat duty than the steam generator, and it need not have high thermal effectiveness. However, for some designs, the auxiliary heat exchanger will probably be designed to accept much higher inlet gas conditions during offdesign conditions. This suggests that high temperature materials may be required. These considerations suggest that the auxiliary heat exchanger will be designed to minimize manufacturing challenges rather than to maximize thermal efficiency.

As a result, the current infrastructure should be able to provide this heat exchanger without significant challenge.

Transport and installation of the auxiliary heat exchanger will not be a major challenge.

\subsection{Auxiliary Cooling System Circulator}

In most aspects, the auxiliary cooling system circulator is expected to be much less challenging than the main circulator. The required capacity is much smaller.

In past assessments of the (MHTGR) Shutdown Cooling System circulator, one significant concern was the motor speed turndown ratio. Since the system is intended to operate over a wide range of conditions including fully pressurized and fully depressurized, a wide range of speed would be required to achieve the required mass flow rate under all conditions. This places significant requirements on the motor and the power supply. While this was a concern, the MHTGR system was believed to be adequate.

Given advances in recent years in synchronous motors and solid state power electronics, this is not expected to be a significant issue today.

Hence, the current industrial infrastructure should be able to supply the auxiliary cooling system circulator without difficulty.

The anticipated suppliers would likely be the same as the main circulator suppliers who are familiar with nuclear industry requirements.

\subsection{Reactor Building}

The specific requirements for the reactor building will depend on the details of the FOAK NGNP design. The specifics provided in Table 2-1 assume a fully or partially embedded structure, and they also assume the need for high-temperature concrete.

\subsubsection{Infrastructure Readiness and High Temperature Concrete}

The advisability of using high temperature concrete in the NGNP reactor building depends strongly on the design of the reactor module and the location within the building. High temperature concrete is considered here as concrete with specific material additions designed to raise its allowed temperature tolerance. In particular, the 
design of the reactor vessel, the reactor cavity cooling system (RCCS), the vessel supports, the structure of the reactor cavity within the reactor building, and the relative position of each of these all combine to determine the required temperature specification for the concrete during normal operation and accident conditions. For example, appropriate design of the RCCS might limit concrete temperatures for all design basis conditions such that high temperature concrete is not required. Or if higher concrete temperatures are expected, they may only require high temperature in the vicinity of the vessel support structures. For example, adequate support of the vessels is clearly necessary, but superficial damage to concrete in the cavity wall surface at the reactor beltline (hottest location) may have no significant impact on safety.

If a decision is made to use high temperature concrete for the NGNP, the ability to procure that concrete will depend on its specific requirements. This depends primarily on time and temperature constraints as well as strength requirements. High temperature concrete can be specified for a variety of applications. Compared to other applications such as refractory installations, the temperature requirements anticipated for the NGNP reactor building would be relatively modest even if high temperature concrete is recommended.

In general the infrastructure exists to provide high temperature concrete. However, since concrete production and installation is ultimately a local process linked directly to the site, final preparation of the infrastructure cannot occur until a site is selected and the specific concrete requirements are established. At that time vendors would be selected and qualified including the production of sample batches meeting the project quality requirements. Of course, this situation is not that different from the process that would be required if conventional concrete is specified throughout the building.

Depending on the temperature for which the concrete will be exposed, the ingredients may not be what the local concrete producer would use. The cement may require different characteristics than normal Type II Portland Cement and the aggregates may need to be a shale, clay or slate material containing a lower percentage of quartz. For the FOAK scenario, the necessary materials could be shipped to the site. It may be more cost effective to explore the use of more local materials for the follow-on NOAK plants.

The concrete plants will need to be designed to store and handle multiple sources of materials to accommodate those required for the various mix designs, including high temperature concrete. The batching and mixing of high temperature concrete is the same as conventional concrete, therefore special or separate plants would not be required.

To ensure the mix design and material availability, high temperature concrete should be treated like a long lead procurement. The mix design could be developed and tested by a laboratory prior to selecting the concrete supplier.

While an infrastructure to provide high temperature concrete at the NGNP site does not exist today, there is no reason to believe that the required infrastructure could not be in place in time to support the project.

\subsubsection{Infrastructure Readiness and Impact of Building Embedment}

Some candidate NGNP concepts have selected fully embedded reactor buildings while others have preferred partially embedded structures. This decision is a function of many factors including construction, operation, plant maintenance, external hazards, cost, etc.

Techniques exist to build both embedded and partially embedded structures at hard rock and soft soil locations, including locations with high water tables. However, the cost of each type of structure will vary substantially for 
the different types of ground conditions. The construction schedule will also be affected. Therefore, it may be appropriate to revisit the structure type once a specific location has been selected.

Ultimately, the current construction infrastructure can support either building approach.

\subsection{Power Conversion System}

The Rankine cycle steam plant anticipated for the NGNP is based on very mature technology. Systems with comparable steam conditions and similar capacities have been used in a variety of fossil power generating applications.

The current infrastructure is clearly ready to support the FOAK NGNP power generating system.

\subsection{Helium Purification System}

The helium purification system uses conventional process technology and components. Moreover, such systems have been built and operated for past and current HTGRs. So the general infrastructure should be able to provide the equipment which makes up the helium purification system without any unusual difficulty.

However, since several of the components are not expected to be off the shelf items, it is prudent to anticipate some procurement and fabrication delays. Thus, early planning, design, and procurement activity will be required to avoid impacting the project schedule.

\subsection{Instrumentation}

Specific NGNP instrumentation requirements depend on the detailed FOAK design, including the final control and protection system details. The requirements will also be influenced by the evolution of the NGNP licensing process. At this time only a general evaluation of the NGNP instrumentation needs and their relationship to the industrial infrastructure is possible.

Current concepts do not require significant exotic instrumentation. Temperature sensors are available to measure core outlet temperature. Flux sensors are available that can operate significantly higher than reactor inlet temperature (for operation in reflectors or cooled channels as necessary).

Therefore, the current infrastructure should be able to meet anticipated NGNP instrumentation needs.

\subsection{Control and Protection Systems}

The NGNP project is expected to use a modern digital control system and a digital protection system. Such systems are standard in conventional process and energy facilities. Moreover, nuclear facilities have begun converting various control systems to digital technology, and the first U.S. nuclear reactors are now being converted to digital protection systems. New LWRs now being licensed intend to use digital control and protection systems.

Since the NGNP project will just follow the first wave of new LWRs now being licensed, the industrial infrastructure will be adequate to support supply, installation, and commissioning of the NGNP control and protection systems. 


\subsection{Miscellaneous Auxiliary Systems}

The NGNP will include several supporting auxiliary systems. Some of these will be unique to an HTGR facility while others will be truly generic.

The fuel handling system for either the prismatic or pebble bed concepts will be unique. The technologies which support this system are generally mature and in use in various industries. However, this system will require a supplier to merge several technologies including machine design, shielding, robotics, automation, and data management systems. While this system is within the capabilities of the current industrial infrastructure, detailed planning will be required to ensure that design, fabrication, testing, and delivery can be accomplished within the anticipated project schedule.

The RCCS is another system that is unique to the NGNP. Several RCCS concepts are currently under consideration by potential NGNP designers. However, all of them utilize very conventional components and structures. Therefore, the current infrastructure is ready to provide this system. Careful integration of this system with the reactor building design will be required. This integration must include evaluation of the building construction sequence in order to ensure that installation of the RCCS equipment does not adversely impact project schedule.

Most other plant systems are truly generic, being similar to comparable systems in other nuclear or fossil power plants. Such systems might include cooling water systems, electrical power buses, etc. While the detailed design of these systems is specific to the NGNP, the general architecture of the system will be similar to other facilities, and the major components would be off the shelf. This current infrastructure is adequate for these systems.

Overall these auxiliary systems do not pose unique challenges for the NGNP. In general, the current infrastructure is adequate to provide and install these systems.

\subsection{Generic Nuclear Power Infrastructure}

Many elements of the NGNP will rely on exactly the same infrastructure as other nuclear construction projects. These generic elements include placing concrete, erecting steel structures, routing cables and piping, component installation and connection, etc. Each of these activities requires the supply of basic materials as well as a variety of skilled labor.

These needs are common to the overall nuclear renaissance. As the renaissance begins, competition for some resources might be significant until the infrastructure is able to catch up. In this regard, the current schedule of the NGNP project is advantageous, since construction of the FOAK NGNP will come slightly after the first wave of new LWRs planned in the US. Thus, any infrastructure limitations should be diminishing as the NGNP moves forward. In any event, these constraints are not expected to have a serious impact on the NGNP project. 


\subsection{INFRASTRUCTURE READINESS FOR FOLLOW-ON HTGRS}

Subsequent deployment of a fleet of follow-on HTGRs for a variety of applications will require a larger infrastructure than that needed to deploy the initial FOAK NGNP. Potential factors driving the greater infrastructure requirements include:

- $\quad$ Large number of reactor modules (mass production)

- Larger components (higher module power levels)

- Higher temperature systems (higher reactor inlet and outlet temperatures)

- New HTGR plant configurations (Brayton cycle, IHX, etc.)

\subsection{Large Scale HTGR Deployment}

Large scale HTGR deployment could eventually involve hundreds of reactor modules. This would require mass production of HTGR components. Construction of the FOAK NGNP would entail fabrication and erection of a single module over the course of 4-5 years, whereas large scale deployment would effectively entail building several reactors every year. The current industrial infrastructure could support deployment of a single FOAK NGNP, but significant expansion of the infrastructure would be required for large scale deployment.

The capacity challenges for wide scale deployment fall into four key areas: large scale components, graphite components, general equipment, and skilled construction labor.

For large scale components, this will require increased capability to produce heavy forgings. Such capacity addition is certainly feasible, but it will require clear demonstration of a sustainable market. This need is shared by the nuclear renaissance in general, so expansion of heavy component capacity need not be supported solely by the HTGR business.

For graphite components, increased production rates for graphite billets and graphite machining will be required. Again such capacity addition is feasible if there is a clear sustainable market. A consideration for graphite is the adequacy of production feedstocks. It is believed that feedstocks for desired graphite grades will be adequate, but this must be confirmed. This need is unique to the HTGR business.

For general equipment and skilled construction labor, this need is shared with the rest of the nuclear industry and even the non-nuclear energy and process industries. Again, capacity addition is feasible if driven by sustained market forces.

Fortunately, market penetration by HTGRs will inevitably be gradual, so demand for follow-on HTGRs will increase in more manageable steps over time. This will allow expansion to be driven by demand.

\subsection{Helium Supply}

It appears that supplies of helium will be adequate to support initial plant and fleet HTR operations. As current U.S. production declines, through depletion of natural gas fields that are the current source of helium and the sale of U.S. government reserves, it is expected that new sources, both domestic and foreign will off-set the decline in 
production. More reliance on foreign helium, or helium from less economic domestic natural gas sources, may impact future price assumptions.

\subsubsection{Background - World Helium Resources}

More than $85 \%$ of the world's current helium supply comes from the U.S. as a by-product of natural gas production and sell-off of U.S. helium reserves. U.S. natural gas containing more than 0.3 percent helium is generally considered economic for helium extraction.

A brief history of the actions taken by the U.S. Government is necessary to understand the development of the U.S. "captive" helium supply. U.S. Government concern over the strategic value of helium resulted in passage of the 1925 Helium Act. This Act nationalized U.S. helium production making it the responsibility of the U.S. Bureau of Mines. In 1960, because of increasing concern over availability of Helium, the government amended the Helium Act by committing to purchase all recoverable helium from certain helium bearing natural gas fields at a predetermined price for the next 22 years. This resulted in the construction of extraction facilities by many private companies specifically for the production of helium for sale to the U.S. Government. By 1973, the Government cancelled its purchase commitment after accumulating a helium inventory of 1 billion $\mathrm{nm}^{3}$. This cancellation and attendant oversupply stimulated the development of commercial applications for helium in the U.S. In 1996 the U.S. Congress passed the Helium Privatization Act which directed the Government to discontinue the production and sale of refined helium by April 1998. The Act also required the Government to sell all of the helium operations it had acquired except for the facility near Amarillo and to offer its helium inventory for sale starting in 2005 with the intention to reduce it to 16 million $\mathrm{nm}^{3}$ by 2015 . Although the US production of helium is currently declining because the natural gas fields that are the source of helium have begun to deplete, the availability of government reserves has off set the decline in production.

USGS reports that in 2003 sales of Grade-A helium (99.995\% or greater purity) were about 80.8 million cubic meters in the U.S. and exports by private producers were 41.3 million cubic meters for total sales of 122 million cubic meters. From 1998 to 2003, the market growth rate was about $2.4 \%$ per year. For the near term, sales of U.S produced helium are expected to remain level because the increased demand for helium exports will be tempered by a reduced domestic demand. Also, increases are expected in foreign production that may slow down the demand for US helium. The Asian market is also expected to remain stable for the next several years.

The above information is based on the data provided in Reference 14.

\subsubsection{Availability of Helium to Support Future HTR Operations}

Because helium availability is tied to natural gas production and processing, analysis of past and present natural gas reserves is a somewhat useful means of gauging the availability of future helium supplies. Although there is no absolute assurance that supplies of natural gas will be available in the future, its availability is reasonably assured because of its importance as a source of energy throughout the world. Continued supplies of natural gas are a result of the dynamic natural gas industry in the United States, which is readily replacing produced reserves through new field exploration and improved recovery technology.

Although helium may play a role in gas field development decisions, companies do not specifically target exploration for helium because its economic status is that of a minor by product. As a result, the geological characteristics and processes that form helium-rich gas deposits are not well known, making deliberate exploration for helium difficult. However, natural gas producers and operators of natural gas processing plants are becoming increasingly aware of the economic rewards of helium extraction. US Bureau of Land Management 
(BLM) conservation and storage programs have played a large role in getting this industry going and in stimulating interest in extraction. As future uses of helium grow, the awareness of helium extraction is likely to grow, perhaps resulting in a larger percentage of helium being extracted from available natural gas streams or even in deliberate exploration for new sources of helium.

It is possible that the U.S. resource base for helium could increase in the future, perhaps from natural gas/helium sources that are not currently economical to produce. This could result from either an increase in the price of natural gas and/or helium. Similar observations could be made with regard to worldwide helium supplies. Liquefied natural gas is an important component in the world's energy supplies. Because methane liquefaction concentrates the remaining gas stream, there are potentially other sources of helium throughout the world, even in low-helium-concentration gases such as those found in Algeria. (Reference 15)

Conversely, we know of no new helium extraction facilities that are expected to come on line in the U.S. in the near future although new facilities in Algeria and Qatar were expected to begin production in 2005 and 2006, respectively. Startup of the facility in Algeria was delayed because of an explosion in a faulty boiler in the natural gas plant and we do not know its current status. It is possible that demand will begin to exceed supply in the near term if there are further delays in foreign production. Should foreign supply not meet expectations, a faster drawdown in the U.S. helium reserves could occur and may "squeeze" the supply, driving prices to higher levels in the future.

\subsubsection{Helium Requirements for HTR Deployment}

The helium inventory required by each reactor module depends on the specific configuration, but a reasonable assumption is $2000 \mathrm{~kg}$ of helium per reactor module. The required helium supply for each reactor module must include both the initial inventory and makeup supply for operating losses. A conservative assumption is to assume the loss of one inventory per year for each module. For example the MHTGR leakage requirement is only $10 \%$ of the primary inventory per year. Assuming 1 inventory per year means a single reactor module would require $2000 \mathrm{~kg}$ per year for sustained operation. This is a trivial quantity in the context of the overall annual helium market. The existing helium infrastructure can readily meet this need.

The ability of the helium infrastructure to support a whole fleet of plants is a more significant question. For a fleet of 500 reactor modules, the total annual helium requirement would be at the most about 1,000,000 $\mathrm{kg}$ per year. This compares to annual global production of over 30 million $\mathrm{kg} / \mathrm{year}$. Therefore, a fleet of HTGRs would be conservatively expected to require only about three percent of current annual global production. If helium is also used for high temperature heat transport loops, this would increase the total helium requirement somewhat, but the basic conclusion would not change. A fleet of HTGRs would not have a large effect on the global helium market.

\subsubsection{Helium Supply Conclusions}

It is likely that supplies of helium will be adequate to support both initial HTR operation and eventual operation of a fleet of HTRs. It is estimated that the yearly helium demand for a fleet of HTRs will not exceed a few percent of the total worldwide helium demand. This level of demand should be readily accommodated by existing and future helium supply infrastructure, particularly given the long lead times associated with new HTR reactor deployments.

Availability is reasonably assured in the near term because helium is tied to natural gas production which is an important source of energy throughout the world. Also, there are many other uses for helium that will support a 
market for this gas. Ultimately, new helium reserves will be brought into production to off-set the decline in the U.S. inventory and depletion of the current U.S. gas fields.

\subsection{Larger Vessels}

As indicated in Table 2-1, future deployment of HTGRs may also lead to larger reactor modules. While some initial designs are in the 200-350 MWt range, modular HTGRs can retain their passive heat removal characteristics up to about twice that size (approximately $500 \mathrm{MWt}$ for pebble bed designs and $600 \mathrm{MWt}$ for prismatic designs). Such a change would require a larger reactor vessel. A single loop configuration would also require a larger steam generator and steam generator vessel, although a multiple loop configuration would possibly be preferred.

For SA508, the forgings required for the larger vessel are just within current infrastructure capacity. Therefore, this expansion would not require additional infrastructure development.

Transportation of the larger reactor vessel would be slightly more challenging. However, this is not expected to be a strong discriminator, since transportation of the intact vessel is already difficult for the smaller reactor vessel unless a navigable waterway is in reasonable proximity to the site.

\subsection{Higher Temperature Vessels}

Several potential follow-on HTGR applications would entail higher reactor operating temperatures, including a higher reactor inlet temperature. For some current configurations, this would result in exposing the inner surface of the reactor vessel to higher temperatures, likely above the limits for SA508/533. Several potential design solutions exist to address this problem:

1. Higher temperature reactor vessel material (e.g., modified 9Cr-1Mo)

2. Move the coolant flow path away from the vessel

3. Add thermal protection to the inside surface of the vessel

4. Use a vessel cooling system

The preferred option would be to change the vessel material to a higher temperature alloy such as modified 9Cr$1 \mathrm{Mo}$. This approach would also provide even greater margins for accident conditions. The other solutions are feasible, but they each involve other tradeoffs which reduce their desirability. In general, they increase design complexity and make assembly more challenging. And they reduce maintainability and reduce performance. While use of the higher temperature alloy requires qualifying a new material, it results in a more optimal design. However, each of the approaches is believed to be feasible.

With respect to infrastructure readiness, only option 1 above would require a significant expansion of the existing infrastructure. While the other options increase the complexity of the system, they are within the capacity of the current infrastructure.

However, fabricating the vessel from modified 9Cr-1Mo imposes challenges slightly beyond the current infrastructure. Two main issues are obtaining heavy forgings of modified $9 \mathrm{Cr}-1 \mathrm{Mo}$ and welding thick sections of modified 9Cr-1Mo. 
JSW currently cannot cast and forge modified 9Cr-1 Mo ingots as large as the ring forgings for a modular HTGR reactor vessel. To be able to do the main flange forgings, larger remelt furnaces and special quenching facilities would be required. These are substantial investments that would only be undertaken in more compelling market conditions.

An alternative approach would be to fabricate the entire vessel from modified $9 \mathrm{Cr}-1 \mathrm{Mo}$ plate except for the nozzle forgings. The individual nozzle forgings are smaller than the vessel ring and main flange forgings. It is believed that the nozzle forgings for this approach could be procured, although that has not been confirmed.

Either fabrication approach would require welding of thick sections of modified 9Cr-1Mo. Significant difficulty obtaining quality welds of thick section modified $9 \mathrm{Cr}-1 \mathrm{Mo}$ has been encountered in the past. AREVA has developed a process to successfully weld thick sections of modified $9 \mathrm{Cr}-1 \mathrm{Mo}$, but this process has not been fully industrialized.

So for future HTGRs with higher reactor inlet temperatures, the preferred solution would be to use a higher temperature material such as modified $9 \mathrm{Cr}-1 \mathrm{Mo}$ for the vessel. However, this will require significant expansion of the current vessel fabrication infrastructure. This expansion is believed to be achievable, but it will be expensive and therefore require strong market incentives. The alternative is to provide thermal protection for the inside surface of the vessel, resulting in other design compromises.

It is conceivable that when HTGRs move into higher temperature markets, the first generation of plants will use conventional vessel materials with engineered thermal protection features. Then the capability for higher temperature vessel materials could be realized once the market for these reactors was well established.

\subsection{Higher Temperature Internals}

\subsubsection{Core Support Structures for Higher Temperature NOAK HTGRs}

For reactor internals components which see the reactor inlet temperature, higher temperature designs are not expected to pose any major challenges. Assuming inlet temperatures increase up to $500^{\circ} \mathrm{C}$, alloy $800 \mathrm{H}$ still has considerable margin, though use above $800^{\circ} \mathrm{F}$ would require evaluation of long-term creep effects and may also require extension of ASME Code stress-time relationships and allowable durations beyond current limits.

Of course the upper core restraint structures will see temperatures above the reactor inlet temperature during accident conditions, and these temperatures will likely be somewhat higher due to the increase in reactor inlet temperature. Therefore, the decision to make these structures from ceramic composites becomes more attractive for the higher temperature design. The infrastructure assessment of this approach is provided in Section 4.2.2. The time when these components would be needed for follow-on plants is far enough in the future, that the process of establishing the required capabilities within the nuclear industry framework is achievable.

It may also be appropriate to employ ceramic composites in the upper plenum shroud which surrounds the reactor inlet plenum for come concepts. This approach would rely on essentially the same infrastructure as the upper core restraint structures. However, expansion of the composite component infrastructure would be necessary, if a single monolithic composite structure was specified for the upper plenum shroud.

The core support structures which see reactor outlet temperature are entirely graphite. These structures are unaffected by the higher temperatures. 


\subsubsection{Hot Duct for Higher Temperature NOAK HTGRs}

Follow-on HTGR plants with higher reactor outlet temperatures will likely use ceramic composite liners for the hot duct inner surface.

The industrial infrastructure should be able to supply these composite components without significant difficulty. As discussed in Section 4.2.2, current industrial experience with composite structures is significant although it is generally outside the nuclear industry. The time when these components would be needed for the hot duct of follow-on plants is far enough in the future, that the process of establishing the required capabilities within the nuclear industry framework is achievable.

\subsection{Intermediate Heat Exchangers}

Some potential future HTGR applications will require direct delivery of very high temperature heat. This is expected to be done via an intermediate heat transport loop connected to the reactor primary circuit through an intermediate heat exchanger (IHX). Various heat transport fluids have been suggested for the secondary heat transport loop, but the most likely candidate for first units would be gas (e.g., high pressure helium). Molten salt has been suggested as an alternative to reduce pumping power requirements, but this technology is not as mature.

Two basic approaches are considered for the IHX design. The traditional approach is the shell and tube heat exchanger. This is similar in concept to the helical coil steam generator, but the design details and materials of construction are different due to the higher temperatures and the use of different fluids. Tubular IHXs are large, and practical units are limited to about $200 \mathrm{MWt}$. Therefore, a reactor module would probably require two or three loops.

The alternate approach is the use of compact heat exchangers. A variety of concepts are being considered including plate-fin, printed circuit or plate machined heat exchangers, plate stamped heat exchangers, etc. These heat exchangers provide a large heat transfer area in a relatively small volume. However, the individual heat exchanger module size is limited to the MW size range, perhaps up to 5-10 MWt in some cases. Hence, a functional IHX for a reactor module would consist of several of these modules connected in parallel. Obviously the required network of headers is not an insignificant challenge, since each module requires four header connections and all relative thermal expansions must be accommodated.

Design and fabrication of a full size IHX is a major technical challenge due to both the high temperatures involved as well as the complexity of the mechanical interfaces.

In discussing the IHX, it is useful to consider two different temperature ranges:

- Moderate temperature (up to $800^{\circ} \mathrm{C}$ or possibly $850^{\circ} \mathrm{C}$ )

- Very high temperature (above $\left.850^{\circ} \mathrm{C}\right)$

Below $800^{\circ} \mathrm{C}$, it may be feasible to use more familiar alloys such as $800 \mathrm{H}$. Above this, it is necessary to use higher temperature alloys such as Inconel 617, Hastelloy X, etc., and even then, these alloys are severely challenged.

The temperature range is very important to the IHX manufacturing infrastructure, because it determines the materials used. For some compact heat exchanger concepts, it also affects the joining technology which might be 
used (e.g., diffusion bonding, brazing, selection of bonding material, etc.). Thus, the manufacturing processes which must be qualified are different for an IHX operating at $750^{\circ} \mathrm{C}$ compared to one designed for $950^{\circ} \mathrm{C}$.

It is important to note that as the hot gas temperature approaches $950^{\circ} \mathrm{C}$, it becomes increasingly difficult to develop a successful IHX design using existing materials. At some point in this vicinity, it will become necessary to use exotic materials such as perhaps oxide dispersion strengthened metallics (ODS) or more probably ceramic heat exchangers. While these technologies are being explored in the laboratory, the required industrial infrastructure necessary to deploy them in follow-on HTGRs does not exist. Development of this infrastructure would require a large effort.

For a tubular IHX, the manufacturing infrastructure is similar to that required for the steam generator (Section 4.6); however the details and the materials of construction are different. This infrastructure existed in the past in Germany, but it would have to be reestablished to support IHX production for a follow-on HTGR for direct heat supply. There is no reason that this could not be done with adequate planning and preparation ahead of time.

Current nuclear component fabricators should be able to satisfy relevant nuclear industry quality requirements for a tubular IHX.

Transportation of the tubular IHX to the plant site would be roughly comparable to delivery of a steam generator. For sites where the reactor vessel could be delivered intact, delivery of a tubular IHX would not be a problem. For less accessible sites, a specific assessment would have to be made taking into account the details of the IHX design as well as local rail and roadway restrictions.

The infrastructure required to provide a compact heat exchanger IHX has two distinct parts. One deals with the production of the individual heat exchanger modules. The other deals with the work required to assemble multiple modules into an integrated IHX.

Significant work has been done in the development of compact IHX modules for HTGR applications. Moreover, industrial production of compact heat exchangers for other non-nuclear applications is done routinely, albeit for lower temperature service. Therefore, assuming successful completion of compact heat exchanger technology development activities, it is reasonable to assume that a supporting manufacturing infrastructure for compact IHX modules could be established. However, more time would be required than for the tubular IHX, since the fabrication processes are not currently as well defined.

Less work has been done on the design issues associated with integrating compact IHX modules into a complete HTGR IHX. This will require a variety of technologies including complex structural support, bellows and other techniques for accommodating thermal expansion, flow balancing, module inspection and replacement techniques, etc. These issues are not unreasonably challenging individually, but they must all be considered in the final design approaches which will then be reflected in the required fabrication, assembly, inspection, and integration processes. Again, it is reasonable to assume that this infrastructure could be established with adequate planning, once the details of the design are defined.

Industrial production of compact IHXs for HTGR applications may require reinterpretation of conventional nuclear industry quality requirements. Full inspection of compact heat exchanger flow passages and volumetric inspection of the assembled heat exchanger modules is generally not practical. Other strategies to assure quality of the finished product must be assessed.

There are two possible approaches to deliver the compact IHX to a plant site. Either final assembly of the integrated IHX is done in the factory and the whole IHX shipped intact, or individual compact IHX modules can 
be shipped to the plant site and the final integration completed there. Integration is easier if done in the factory shop with the appropriate space, specialized tooling, and trained staff. However, the resulting integrated IHX is extremely large and heavy. Depending on the final design, the vessel housing the integrated IHX may be as large as the reactor vessel. Even if final assembly is done at the site, the IHX housing vessel and piping must still be shipped to the site. Hence, the compact IHX has shipping constraints comparable to the other large components. For sites where the reactor vessel can readily be shipped, compact IHX delivery should not be a problem. Other less accessible sites will require detailed evaluation. Depending on the final design of the IHX, some extreme sites might even require on-site fabrication of the IHX vessel.

Previous NGNP studies documented in References 10, 11, and 12 provide detailed discussions of many of these issues.

\subsection{High Temperature Valves}

Some direct process heat HTGR configurations may require very high temperature helium valves for isolation of the primary or secondary heat transport circuit. Such valves were developed and tested as part of the German HTGR process heat program in the 1980s.

The technology to fabricate these valves exists today, however there are currently no known manufacturers producing such valves. It is reasonable to assume that such valves could be procured in the future provided attractive business incentives were available for potential manufacturers. However, significant lead time would be required. It is likely that past design approaches would be updated with current materials. In any event, assembly processes would have to be developed and qualified. If the design was not identical to the past concept tested in Germany, a significant component qualification program might be required. As for many components for advanced very high temperature reactors, significant long-term planning would be required to ensure that the critical path would not be impacted. Nonetheless, with such adequate planning, procurement of very high temperature valves should not pose a major issue.

\subsection{Brayton Cycle PCS}

Since the 1970s it has been recognized that direct coupling of a closed Brayton cycle to a HTGR could offer advantages for efficient electricity production. It is reasonable to assume that future follow-on HTGRs might adopt this configuration.

The gas turbine to be used in an HTGR would most likely be a helium turbine on magnetic bearings, although oil bearing systems have also been considered. The machine would be smaller than large stationary gas turbines in common use today. It would be expected to have tighter tolerances. However, it is well within the overall range of gas turbines produced today.

The gas turbine industry produces a wide variety of machines, ranging from small to extremely large aircraft engines and aero-derivative stationary engines to large stationary engines designed for dedicated power production. They include units designed for marine propulsion and very small units used in spacecraft applications with various fluids.

It should be mentioned that some integrated gas turbine generators that have been considered for advanced HTGRs challenge the limits of current magnetic bearing technology, particularly for the thrust catcher bearing. While this is more of a technology development issue than an infrastructure readiness issue, the two issues are 
undoubtedly connected. This could limit the size or configuration of gas turbine installations until necessary technology development is completed.

The current gas turbine infrastructure is adequate to produce a gas turbine for a closed Brayton cycle HTGR system.

The closed Brayton cycle also requires a recuperator for efficient operation. Current recuperator technology should be adequate for this application. The industrial infrastructure is adequate to provide a recuperator for a closed Brayton cycle HTGR system. 


\subsection{INFRASTRUCTURE READINESS SUMMARY TABLE}

The following table provides a summary of many of the issues discussed in the earlier sections of this report using a three tier system as follows:
A - No significant issues, normal project planning practices should be sufficient
B - Minor issues. Project schedule should be supportable with advanced planning and focus
C - Significant problems/development required, may impact project schedule

Table 6-1 Infrastructure Assessment Review Summary

\begin{tabular}{|c|c|c|c|c|c|c|c|}
\hline & \multicolumn{3}{|c|}{ Ability to Provide Components } & \multirow{2}{*}{$\begin{array}{c}\text { Ability to } \\
\text { Meet QA } \\
\text { Requirements }\end{array}$} & \multirow{2}{*}{$\begin{array}{c}\text { Capability to } \\
\text { Transport } \\
\text { Components }\end{array}$} & \multirow[b]{2}{*}{$\begin{array}{l}\text { Workforce } \\
\text { Readiness }\end{array}$} & \multirow[b]{2}{*}{$\begin{array}{c}\text { Construction } \\
\text { Capability }\end{array}$} \\
\hline & $\begin{array}{l}\text { Technical } \\
\text { Readiness }\end{array}$ & $\begin{array}{l}\text { Industrial } \\
\text { Readiness }\end{array}$ & $\begin{array}{c}\text { Commercial } \\
\text { Readiness }\end{array}$ & & & & \\
\hline \multicolumn{8}{|c|}{ FIRST-OF-A-KIND HTGRs } \\
\hline Primary Coolant Vessels & A & A & $\mathrm{B}^{1}$ & A & $\mathrm{B}^{2}$ & A & $\mathrm{A}$ \\
\hline Core Support Structures & -- & -- & -- & -- & -- & -- & -- \\
\hline Reactor Internals Metallics & $\mathrm{B}^{3}$ & $\mathrm{~A}$ & $\mathrm{~A}$ & $\mathrm{~A}$ & $\mathrm{~B}^{2}$ & A & A \\
\hline Reactor Internals Ceramics & A & $\mathrm{A}$ & A & $\mathrm{C}^{4}$ & A & A & $\mathrm{A}$ \\
\hline Graphite Components & $\mathrm{A}$ & $\mathrm{A}$ & A & $\mathrm{B}^{5}$ & $\mathrm{~A}$ & A & $\mathrm{A}$ \\
\hline Control Rods & -- & -- & -- & -- & -- & -- & -- \\
\hline Metallic Control Rods & A & A & A & $\mathrm{A}$ & $\mathrm{A}$ & $\mathrm{A}$ & A \\
\hline
\end{tabular}


Infrastructure Readiness Assessment for the NGNP

\begin{tabular}{|c|c|c|c|c|c|c|c|}
\hline & \multicolumn{3}{|c|}{ Ability to Provide Components } & \multirow{2}{*}{$\begin{array}{c}\text { Ability to } \\
\text { Meet QA } \\
\text { Requirements }\end{array}$} & \multirow{2}{*}{$\begin{array}{c}\text { Capability to } \\
\text { Transport } \\
\text { Components }\end{array}$} & \multirow[b]{2}{*}{$\begin{array}{l}\text { Workforce } \\
\text { Readiness }\end{array}$} & \multirow[b]{2}{*}{$\begin{array}{c}\text { Construction } \\
\text { Capability }\end{array}$} \\
\hline & $\begin{array}{l}\text { Technical } \\
\text { Readiness }\end{array}$ & $\begin{array}{l}\text { Industrial } \\
\text { Readiness }\end{array}$ & $\begin{array}{c}\text { Commercial } \\
\text { Readiness }\end{array}$ & & & & \\
\hline Ceramic Control Rods & A & A & A & $\mathrm{C}^{4}$ & A & A & $\mathrm{A}$ \\
\hline Hot Duct & A & A & A & A & A & A & A \\
\hline Steam Generator & A & A & $\mathrm{B}^{6}$ & $\mathrm{~A}$ & $\mathrm{~B}^{2}$ & A & A \\
\hline Main Circulator & A & A & A & A & A & A & $\mathrm{A}$ \\
\hline $\begin{array}{l}\text { Auxiliary Cooling System Heat } \\
\text { Exchanger }\end{array}$ & A & A & A & A & A & A & A \\
\hline $\begin{array}{l}\text { Auxiliary Cooling System } \\
\text { Circulator }\end{array}$ & A & A & A & A & A & A & A \\
\hline Reactor Building & -- & -- & -- & -- & -- & -- & -- \\
\hline High Temperature Concrete & A & $\mathrm{B}^{7}$ & $\mathrm{~A}$ & $\mathrm{~B}^{7}$ & A & A & $\mathrm{A}$ \\
\hline Impact of Building Embedment & A & $\mathrm{A}$ & A & A & A & $\mathrm{A}$ & A \\
\hline Power Conversion System & A & $\mathrm{A}$ & A & A & A & A & A \\
\hline Helium Purification System & A & A & $\mathrm{B}^{8}$ & $\mathrm{~B}^{8}$ & A & A & $\mathrm{A}$ \\
\hline Instrumentation & A & $\mathrm{A}$ & A & A & A & A & A \\
\hline Control and Protection Systems & A & $\mathrm{B}^{9}$ & $\mathrm{~B}^{9}$ & $\mathrm{~A}$ & $\mathrm{~A}$ & $\mathrm{~A}$ & $\mathrm{~A}$ \\
\hline
\end{tabular}


Infrastructure Readiness Assessment for the NGNP

\begin{tabular}{|c|c|c|c|c|c|c|c|}
\hline & \multicolumn{3}{|c|}{ Ability to Provide Components } & \multirow{2}{*}{$\begin{array}{c}\text { Ability to } \\
\text { Meet QA } \\
\text { Requirements }\end{array}$} & \multirow{2}{*}{$\begin{array}{c}\text { Capability to } \\
\text { Transport } \\
\text { Components }\end{array}$} & \multirow[b]{2}{*}{$\begin{array}{l}\text { Workforce } \\
\text { Readiness }\end{array}$} & \multirow[b]{2}{*}{$\begin{array}{c}\text { Construction } \\
\text { Capability }\end{array}$} \\
\hline & $\begin{array}{l}\text { Technical } \\
\text { Readiness }\end{array}$ & $\begin{array}{l}\text { Industrial } \\
\text { Readiness }\end{array}$ & $\begin{array}{l}\text { Commercial } \\
\text { Readiness }\end{array}$ & & & & \\
\hline Miscellaneous Auxiliary Systems & A & A & A & $\mathrm{A}$ & A & A & A \\
\hline $\begin{array}{l}\text { Generic Nuclear Power } \\
\text { Infrastructure }\end{array}$ & A & A & A & A & A & A & A \\
\hline \multicolumn{8}{|c|}{ FOLLOW-ON HTGRS } \\
\hline Large Scale HTGR Deployment & A & $\mathrm{B}^{10}$ & $\mathrm{~B}^{10}$ & $\mathrm{~A}$ & $\mathrm{~B}^{11}$ & $\mathrm{~B}^{10}$ & A \\
\hline Larger Vessels & A & $\mathrm{B}^{12}$ & $\mathrm{~B}^{12}$ & $\mathrm{~A}$ & $\mathrm{~B}^{12}$ & A & A \\
\hline Higher Temperature Vessels & A & $C^{13}$ & $\mathrm{C}^{13}$ & $\mathrm{~A}$ & $\mathrm{~B}^{2}$ & A & A \\
\hline Higher Temperature Internals & -- & -- & -- & -- & -- & -- & -- \\
\hline $\begin{array}{l}\text { Core Support Structures for } \\
\text { Higher Temperature NOAK } \\
\text { HTGRs }\end{array}$ & A & A & A & $\mathrm{B}^{14}$ & A & A & A \\
\hline $\begin{array}{l}\text { Hot Duct for Higher } \\
\text { Temperature NOAK HTGRs }\end{array}$ & A & $\mathrm{B}^{14}$ & A & $\mathrm{B} / \mathrm{C}^{14}$ & A & A & A \\
\hline Intermediate Heat Exchangers & $C^{15}$ & $C^{15}$ & $\mathrm{C}^{15}$ & $\mathrm{~B}^{16}$ & $\mathrm{~B}^{17}$ & A & A \\
\hline High Temperature Valves & A & $\mathrm{A}$ & $\mathrm{B}^{18}$ & A & A & A & A \\
\hline Brayton Cycle PCS & A & A & $\mathrm{B}^{19}$ & $\mathrm{~B}^{19}$ & A & A & A \\
\hline
\end{tabular}




\section{Notes on individual Rankings:}

1. Production of the Reactor Vessel will be limited by the forged vessel flange ring. It appears at this time that a single vendor (JSW) can produce this forging. Given the significant role that this vendor plays in the ongoing nuclear renaissance, early ordering of this component critical to minimize schedule risk.

2. Locations away from navigable waterways may need to consider shipment of the reactor vessel as partially completed components, with final assembly conducted in site. Shipping of reactor internals components and steam generators to these sites may also require special considerations.

3. Codification of candidate materials for the explicit service conditions anticipated may need to be completed.

4. Most vendors of ceramic composite components do not have NRC approved QA programs. Additionally, the NRC does not have a precedent for acceptance of composite materials.

5. Reproducibility of graphite material properties will need to be addressed with the NRC.

6. Development of modern fabrication techniques is needed for the helical coil design. The ongoing nuclear renaissance may limit the number of vendors willing to incur this expense and schedule impact for a one-of-a-kind plant.

7. Procurement of the required quantities of specialized concrete to NRC approved standards will be based on local suppliers, which may add some schedule risk or may require development or expansion of a local infrastructure.

8. Though helium purification systems were procured for past HTGRs, most of today's suppliers will not have NRC approved QA programs. The relatively small size of the potential near term market may limit the number of vendors willing to make this investment.

9. Current reactors are just beginning to implement digital controls. As this technology matures and receives more NRC attention, this area may become a less significant risk.

10. As more HTGRs are planned, competition for available resources with other reactor types may result. In addition, supplies of HTGR-specific materials (graphite precursor materials, helium, etc.) will need to be addressed. 
11. Larger deployments of HTGRs may result in more reactors being located away from navigable waterways, increasing the need for on-site assembly of reactor vessels.

12. Production of vessels much larger than those for the largest currently envisioned plants (around 600 MWth) will require increased forging capability. These vessels will increase the likelihood of required on-site final assembly.

13. The current material envisioned for higher temperature operation (Modified $9 \mathrm{Cr}-1 \mathrm{Mo}$ ) requires development and industrialization of production welding processes. In addition, it is not clear that JSW will be willing, or able, to produce the largest required vessel forgings in a timely manner.

14. Higher temperature operation may require extension of currently Codified limits for key materials. For ceramic composite materials that may be required for use in the Hot Duct, extensive code development may be necessary.

15. Significant IHX development is required prior to implementation. Development needs depend on IHX type, working fluid characteristics, plant operating temperatures and powers, amongst other considerations.

16. Many IHX designs currently under consideration will require development of specific testing and acceptance requirements that have not been considered in the nuclear industry.

17. Transportation of tubular IHXs will involve many of the same considerations as encountered in transportation of reactor vessels and steam generators.

18. Though high temperature valves have been produced and tested in the past, process and equipment development will be required of a new vendor to produce this type of valve. This will require a strong business incentive for the vendor.

19. Most vendors considered able to supply Brayton cycle components do not currently supply the nuclear industry. Process and program updates will likely be required. 


\subsection{CONCLUSIONS}

\subsection{Summary of Current Infrastructure Readiness}

Key points regarding the readiness of the current industrial infrastructure to support the FOAK NGNP are summarized below:

- The industrial technology and required facilities to produce the NGNP primary vessels are established. However, these facilities have limited capacity and are seeing significant demand. Therefore, commercial readiness is a challenge. Steps must be taken to minimize the risk to the project schedule. In 2008 AREVA had recommended that vessel procurement be initiated as soon as possible. The longer this is delayed the more significant the risk, and the fewer options that will be available.

- The current infrastructure can meet the quality requirements for the primary coolant vessels.

- Depending on the location of the NGNP, delivery of the vessel components to the plant site may pose a challenge due to the size of the reactor vessel. Delivery to coastal sites or sites near navigable waterways is feasible using the current infrastructure. For inland sites, completion of reactor vessel fabrication at the NGNP site provides an alternative to delivery of the intact vessel. This would result in additional cost and potential delay for the project. For most future commercial sites, heavy component delivery is not believed to be an insurmountable problem, since navigable waterways are in reasonable proximity to most industrial regions.

- A variety of alloys are under consideration for reactor internals components. There is substantial industrial experience in producing components from these alloys. However, their use in the nuclear industry has been limited. Either current fabricators working with these materials will have to institute procedures and quality programs to meet nuclear industry requirements (as applicable to the specific component being fabricated), or current nuclear component fabricators will have to expand their use of these materials. Both of these approaches are feasible and able to meet the requirements of the NGNP project given reasonable planning and preparation.

- Clearly the infrastructure for ceramic composite reactor internals components is not as mature as for metallic components. A substantial industrial infrastructure exists for composite materials and components including $\mathrm{C}-\mathrm{C}$ composites, particularly in the aerospace industry. However, there is little experience with these composites in the nuclear industry. The qualification of these components for use in the NGNP poses a challenge. Once a qualification strategy is identified, it will have to be implemented within the production infrastructure.

- The graphite infrastructure is believed to be adequate to produce the quantity of the selected grade of nuclear graphite on the planned NGNP production schedule. This assumes that the required quantity of graphite is ordered in a timely manner.

- The current infrastructure is adequate for metallic control rods.

- The infrastructure for the ceramic composite control rods is less well established. Careful planning and preparation will be required to ensure the readiness of the supporting infrastructure. 
- It should be noted that control rods are replaceable components. Therefore, the path with least risk for near-term deployment may involve initial use of metallic rods at the beginning of plant life with future substitution of composite or hybrid metallic-composite rods for improved performance margins.

- The current infrastructure is adequate to provide the hot duct.

- The current infrastructure is adequate to provide the steam generator.

- The current infrastructure is adequate to provide the main circulator.

- The current infrastructure is adequate to provide the auxiliary cooling system heat exchanger.

- The current infrastructure is adequate to provide the auxiliary cooling system circulator.

- High temperature concrete is currently available. However, the local concrete supply infrastructure will have to be qualified to produce concrete based on the NGNP requirements (whether high temperature concrete is specified or not).

- The construction infrastructure can support both fully and partially embedded structures for a range of site conditions. However, for a given site, cost and schedule may vary significantly between the two approaches.

- The current infrastructure for the Rankine power conversion system is adequate to support the FOAK NGNP project.

- The current infrastructure can provide the helium purification system equipment assuming adequate lead time is provided for procurement of custom equipment.

- The current infrastructure should be able to meet anticipated NGNP instrumentation needs.

- The developing infrastructure will be able to provide digital control and protection systems required for the FOAK NGNP project.

- Overall the auxiliary systems do not pose unique challenges for the NGNP. The current infrastructure is adequate to provide and install these systems. Timely planning and preparation will ensure that supply of the systems using significant components which are not off the shelf (e.g., fuel handling) does not adversely impact project schedule.

- Infrastructure concerns due to general material and skilled labor constraints are common to the overall nuclear renaissance. Given that construction of the FOAK NGNP will come slightly after the first wave of new LWRs, infrastructure limitations should be diminishing as the NGNP moves forward. These constraints are not expected to have a serious impact on the NGNP project.

\subsection{Summary of Infrastructure Readiness for Follow-On NOAK Plants}

Key points regarding the capability of the industrial infrastructure to support deployment of a future fleet of HTGRs including follow-on plants with enhanced capabilities are summarized below: 
- Large scale deployment of HTGRs will require expansion of the industry capacity for large components (e.g., heavy forgings) and for nuclear grade graphite. The required expansion should be achievable given that market penetration by HTGRs will inevitably be gradual. This will allow expansion to be driven by demand.

- Larger vessels to accommodate higher module capacity up to the limit of passive cooling are within current infrastructure capacity for SA508 vessels. Transportation of the larger reactor vessel would be slightly more challenging, although this is not expected to be a strong discriminator.

- For future HTGRs with higher reactor inlet temperatures, the preferred solution would be to use a higher temperature material such as modified $9 \mathrm{Cr}-1 \mathrm{Mo}$ for the vessel. However, this will require significant expansion of the current vessel fabrication infrastructure. This expansion is believed to be achievable, but it will require strong market incentives. The alternative is to provide thermal protection for the inside surface of the vessel, resulting in other design and performance compromises.

- Higher reactor inlet temperatures are not expected to pose any major challenges for reactor internals components. Alloy $800 \mathrm{H}$ still has considerable margin at the anticipated temperatures. Therefore, the existing infrastructure should be adequate.

- However, due to slightly higher accident temperatures for the higher temperature design, the decision to use ceramic composites for the upper core restraint structures becomes more attractive. If composites are selected, the infrastructure for ceramic composite reactor components would be necessary. In that case, it might also be appropriate to employ ceramic composites in the upper plenum shroud.

- Follow-on HTGR plants with higher reactor outlet temperatures will likely use ceramic composite liners for the hot duct inner surface.

- For a tubular IHX, the manufacturing infrastructure would have to be reestablished to support IHX production for a follow-on HTGR for direct heat supply. There is no reason that this could not be done with adequate planning and preparation ahead of time. It should be able to satisfy relevant nuclear industry quality requirements. Transportation of the tubular IHX to the plant site would be roughly comparable to delivery of a steam generator.

- For a compact IHX, the infrastructure required to produce the individual heat exchanger modules and to assemble multiple modules into an integrated IHX does not exist today. Assuming successful completion of compact heat exchanger technology development activities, it is reasonable to assume that a supporting manufacturing infrastructure for compact IHX modules could be established. It is also reasonable to assume that the infrastructure to assemble the integrated IHX could be established with adequate planning, once the details of the design are defined. However, more time would be required than for the tubular IHX, since the fabrication processes are not currently as well defined.

- Quality requirements may have to be reinterpreted for compact IHXs, since full inspection of compact heat exchanger modules is generally not practical.

- For sites where the reactor vessel can readily be shipped, compact IHX delivery should not be a problem. Other less accessible sites will require detailed evaluation. 
- At some point in the vicinity of $950^{\circ} \mathrm{C}$, the IHX will require exotic materials such as ODS or ceramic heat exchangers. Development of the industrial infrastructure necessary to deploy such IHXs would require a large effort.

- The current gas turbine infrastructure is adequate to produce a gas turbine for a closed Brayton cycle HTGR system. (Catcher bearing limitations could constrain some limiting configurations until necessary technology development is completed.)

- The current industrial infrastructure is adequate to provide a recuperator for a closed Brayton cycle HTGR system. 
Infrastructure Readiness Assessment for the NGNP

\subsection{REFERENCES}

1. "Statement of Work for Infrastructure Readiness Assessment for Next Generation Nuclear Plant". SOW8961 Rev. 0, Idaho National Laboratory, July 20, 2010.

2. AREVA Report 12-9076324-001, "NGNP with Hydrogen Production RPV and IHX Pressure Vessel Alternatives", April 2008.

3. GA Report 911118, Rev. 0, "RPV and IHX Pressure Vessel Alternatives Study Report”, April 2008.

4. INL Report INL/EXT-08-13951, Rev. 0, "Next Generation Nuclear Plant Reactor Pressure Vessel Acquisition Strategy", April 2008.

5. Westinghouse Report NGNP-NHS-TI-COMP, Rev. 0, "NGNP Conceptual Design Study: Composites R\&D Technical Issues”, October, 2008.

6. GA Report 911125, Rev. 0, "NGNP Composites R\&D Technical Issues Study”, October 2008.

7. GA Report 911175 Rev. 0, Effect of Reactor Outlet Helium Temperature on the Need for Composites in the NGNP", June 2009.

8. INL Report INL/EXT-06-11102, Rev. 0, “AGC-1 Irradiation Experiment Test Plan”, May 2006.

9. ORNL Report ORNL/TM-2007/153, NGNP Graphite Selection and Acquisition Strategy”, September 2007.

10. GA Report 911119, Rev. 0, "NGNP IHX and Secondary Heat Transport Loop Alternatives Study”, April 2008.

11. INL Report INL/EXT-08-14054, Rev. 0, "Next Generation Nuclear Plant Intermediate Heat Exchanger Acquisition Strategy", April 2008.

12. AREVA Report 12-9076325-001, "NGNP - IHX and Secondary Heat Transport Loop Alternatives", April 2008.

13. N. Salstrom, et.al., Toyo Tanso, "Quality Control of Nuclear Graphite", $10^{\text {th }}$ International Nuclear Graphite Specialists Meeting, September, 2009.

14. “Helium”, U.S. Geological Survey Minerals Yearbook, 2003, Norbert Pacheco

15. "The Impact of Selling the Federal Helium Reserve", National Academy of Sciences, 2000 
Document No.: 12-9142633-002

Infrastructure Readiness Assessment for the NGNP

\section{Appendix A - Graphite Vendor Responses to Questions}

\section{Short Term Graphite Supply - FOAK Plant}

Question 1: Do you currently produce any components from nuclear grade graphite? If so, what are they? What quantities do you produce? Is there a quality standard? If so, what is it?

$\underline{\text { Toyo Tanso Answer }}$

Toyo Tanso produces a variety of components from nuclear grade graphite.

We have IG-110 graphite, IG-430U graphite and CX-2002U carbon fiber composite for nuclear applications. Both IG-110 and IG-430U are included in the INL AGC program.

IG-110 Graphite is currently used for High Temperature Gas-Cooled Reactors (HTGR). We have sales and production experience for the High Temperature engineering Test Reactor (HTTR) (Japan) and HTR10 (China). We are currently producing material to supply for the HTR-PM demonstration reactor (China). IG-430U graphite and CX-2002U carbon fiber composite are used for Fusion Reactor applications, though IG-430U is being considered as a possible HTGR material due to its enhancement of strength through particle distribution control while maintaining other important HTGR properties. We have production experience at JT-60 (Japan), LHD (Japan), and KSTAR (South Korea). It is now also supplied to JT-60SA (Japan). In addition, CX-2002U is the only candidate material in ITER (EU).

Our current production capacity for nuclear applications is approximately 1000 ton per year.

We have a quality standard to satisfy requirements of ISO -9001, which also complies with HTTR inspection standard for graphite products. We were also recently audited by Idaho National Laboratories to be a qualified supplier for NGNP as well as a precursor to NQA-1.

\section{$\underline{\text { SGL Answer }}$}

SGL is delivering fuel sleeves to Westinghouse UK (formerly BNFL) for the British Advanced Gas Reactors. The material is similar to our NBG17 and NBG18 (main difference is in the way the graphite is manufactured. The sleeves are extruded while NBG17 and NBG 18 is vibro-moulded.). We are constantly running small batches of NBG17 and NBG18 for research. Furthermore we are the chosen supplier for the Chinese HTR-PM project for the moderator balls based on our extruded material MLRF-1. We are delivering synthetic graphite powder for the fuel matrix to Babcock \& Wilcox, Institute of Nuclear and new Energy Technology (INET), and others.

The quantities for Westinghouse UK are more than 500 MT (metric tons) annually, but further details cannot be disclosed. For NBG17 and NBG18 we produce between 5 and 10 MT annually. The dummy balls for the Chinese Project will be in the several hundred of thousands.

All involved production sites are certified according to ISO 9001. Production fulfils NQA-1 requirements. Testing is done according to ISO, ASTM and ASME standards as well as other country or customer specific requirements. 
Infrastructure Readiness Assessment for the NGNP

Question 2: How much time is required to produce the required quantity of raw graphite material required for the NGNP? How much lead time is required to order this quantity of materials?

\section{$\underline{\text { Toyo Tanso Answer }}$}

Lead time will be determined by the quantity demanded for the NGNP design. Production schedules are determined by the quantity of material needed by the customer. Under the assumption that the NGNP HTGR uses up to 2000 tons, it would take approximately two and a half to 3 years with lead-time of approximately 6 month.

\section{$\underline{\text { SGL Answer }}$}

The demand of the competing technologies prismatic vs. pebble, are not negligible. However for this questionnaire we will assume that the graphite needed is comparable. Assuming approx. 1,200 MT of graphite parts, it would take 3 years to produce the required material. Depending on ones needs, more resources could be allocated to reduce delivery times. A business case would need to be completed to determine how the additional resources would change delivery times and their effect on pricing.

It will take roughly 3 years to establish a new location to manufacture the graphite if the graphite manufacturing is to be located near the reactor construction site. This time would be dependent on using an existing SGL site and revamping it or if we need to build a new facility. If delivery is initiated from our current production facility it will only take 1 year. A machine shop would be set up locally no matter where the material is produced, but this would not add extra time because the production of the material is the long lead time item in the system. A machine shop can be set up within the timeframe to produce the graphite itself.

Question 3: Would the vendor do the required machining? What is the estimated time to complete fabrication of the components?

\section{Toyo Tanso Answer}

Toyo Tanso has the full capability of graphite production, purification, machining and inspection of the graphite. In order to estimate lead time it is important to understand the product shape and quantity of the requested material. We have a large capacity of machining available in Japan, US, China and European countries. Without product specifications and design it is difficult to show accurate machining numbers however estimating a 2000 ton consumption of graphite for the NGNP, machining time could be two to three years, with a 1 to 1.5 year required lead time from initial order to start of machining operations.

\section{$\underline{\text { SGL Answer }}$}

Yes, we would machine the components out of the graphite.

The machining lead-time is included in the 3 years overall schedule. Parts would start to be machined from the first available material (approx. after 1 year) until the end of the delivery schedule. The defining part in determining the overall delivery time is the graphite manufacturing and not the machining. Machining can be easily adapted within reasonable costs to the predicted output of the graphite manufacturing. 
Question 4: Is the vendor compliant with NQA-1, ISO, ASME, ASTM or other quality standards? If so, what are the quality standards?

Toyo Tanso Answer

Toyo Tanso is complying with ISO-9001 standards which meet with HTTR inspection standards for graphite products. Toyo Tanso also participates in ASME and ASTM standards meetings as they are being developed for nuclear graphite. Inspection can be performed to JIS, ASTM or other standards requested by the end user. Toyo Tanso is not currently NQA-1 certified, but have been placed on the INL QSL for supply of AGC graphite.

$\underline{\text { SGL Answer }}$

Certified according to ISO 9001. Production fulfils NQA-1 requirements. Testing is done according to ISO, ASTM and ASME standards as well as other country or customer specific requirements.

Question 5: Which industry specifications and/or codes would be envisioned to govern the production of the graphite material? Are code improvements needed? If so, what are they?

\section{Toyo Tanso Answer}

We have been producing graphite products for many years according to a professional QC progress schedule which we have established within Toyo Tanso. Our material has been produced with a track record of high quality and property stability for many years. We can show over 35 years of consistency in our IG-110 nuclear graphite. We feel it is not necessary to change our QC progress schedule. We are currently working with ASTM to develop useful specifications and standards.

\section{$\underline{\text { SGL Answer }}$}

ASTM and ASME. The ASME would encompass the NQA-1 and ASTM.

The ASME shall be finalized. The ASTM is continuously improved. The current set-up for development and improvement are sufficient and satisfactorily.

Not applicable.

Question 6: What is your process for demonstrating that the graphite produced meets key performance attributes, required specifications, and standards? In other words, how is reproducibility of the graphite product demonstrated such that qualification tests are shown to be applicable to the graphite actually used for reactor components?

\section{Toyo Tanso Answer}

The process parameters and product characteristics are strictly measured and controlled on each process of production to meet requirements.

We inspect physical properties, Bulk density, Hardness, Electrical resistivity, Flexural strength, Compressive strength, CTE and so forth. We have confidence in the consistency of each grade of our material based on the quality standards and material specification which have been put in place. We can 
demonstrate long term production histories and stability for our materials. Reference 13 provides more details regarding long term material reproducibility.

$\underline{\text { SGL Answer }}$

Sampling and testing (both destructive and nondestructive) of raw materials, intermediate and final products according to relevant industry specifications and/or standards and codes. Testing can be done inhouse as well as by 3rd parties. All testing laboratories should have an accreditation to the relevant industry specifications and/or codes and standards.

Production is done according to a quality plan including procedures where all recipes and process parameter are fixed. This quality plan will be aligned at the beginning of the project with the customer, independent inspectors as well as the responsible nuclear regulator. It would be comprised with the applicable codes and standards, further customer or industry specifications, recipes, production processes and parameters, sampling and testing procedures, the involved testing facilities and laboratories and it would define the HOLD- and WITNESS-points.

\section{Long Term Graphite Supply - NOAK Plants}

Question 7: What is the long-term outlook for the availability of the identified preferred grade(s) of graphite from this vendor?

\section{Toyo Tanso Answer}

The IG-110 graphite grade has been in production for over 35 years from development to the present, and it is used not only for the nuclear graphite but also as global standard grade for various isotropic graphite applications.

Toyo Tanso has also succeeded the development of IG-430 graphite as a material for the next generation of nuclear applications based on the sufficient production experience and know-how obtained through IG110 production.

We are confident with the ability to supply stable next generation graphite for long term projects.

\section{$\underline{\text { SGL Answer }}$}

All recipes and production processes are frozen and in all detail defined in a quality plan. The raw material supply is secured by a long-term supply agreement. SGL is prepared to deliver nuclear graphite as of today, however long term outlooks, in particular for NOAK plants, can only be based on bilateral agreements as NOAK plants would definitely require considerable expenditures and the allocation of resources.

Question 8: What actions can be taken to establish alternate supplies of key feed materials? What, if any impact would the use of such alternates have on the properties and qualification status of the graphite grade?

$\underline{\text { Toyo Tanso Answer }}$ 
The raw materials used for our graphite production have a stable supply source secured for a long term basis. We are confident with our stable supply chain in the future. As an alternative product grade to IG110 we have IG-430 raw material supply of which has been also prepared.

\section{$\underline{\text { SGL Answer }}$}

Alternative supplies for raw materials and also significant changes in the specification of the raw materials would normally require a new qualification of the grade. Understanding of the influences of exchanging the raw material for the "nuclear" properties, in particular behavior in irradiation is not fully understood by many parties. Thus, any "new" raw material might lead to a "new" graphite grade in terms of nuclear properties. However in Germany this problem was already "solved" and the information is available to SGL as we were the chosen supplier for the German HTR project at that time. In any case a "new" grade requires qualification via a program as currently initiated by the DOE.

This question can not be answered currently as the impact on the "nuclear" properties is not enough understood. Therefore it is essential to freeze the recipes and production processes and bind the suppliers with long-term agreements.

Question 9: What is the anticipated achievable production rate for this material? In other words, how many new plants can be supplied per year? How many fuel reloads? How many reflector replacements? What can be done to increase this production rate?

\section{$\underline{\text { Toyo Tanso Answer }}$}

In order to accurately answer this question we will need to understand the production requirements in amounts per year to replace the reflector graphite and the fuel graphite. With a 2000 ton graphite consumption assumed for the NGNP, we are capable of supplying 2 plants per year equivalent graphite as needed. If necessary we can also build a new production factory to satisfy the quantity of customer demand.

IG-110 is used by many industries beyond the nuclear industry and forms a large portion of Toyo Tanso business. Plans are in place to provide for expansion of capacity to support various business scenarios. Since feed stocks are by-products of the petroleum industry, suppliers of these materials are expected to be able to easily respond to changes in supply needs.

\section{$\underline{\text { SGL Answer }}$}

There are no technical limitations to the achievable production rate, but time-frame and commercial issues need to be studied. SGL has a strong presence in North America and is one of the globally leading manufacturers of carbon and graphite. Any availability of existing resources in the long term cannot be predicted, but any producer aims at loading its plants at full capacity. Therefore agreements need to be implemented to secure the supply of graphite for HTR's as the amount needed is considerable for specialty graphite. Based on such agreements a capacity for nuclear graphite in the range of 10-15,000 MT seems to be technically possible.

Assuming 1200 MT for the graphite for a HTR (regardless if it is a pebble or prismatic design) a capacity of 10,000 MT would yield 8 plants per annum. 
Assuming 1000 MT for a reflectors and 200 MT for fuel blocks on a prismatic design 5 fuel reloads would equal 1 new reactor. However for a pebble bed design this constraint does not exist as the graphite manufacturer only delivers graphite powder for the fuel compacts.

Question 10: What situations can be envisioned that would impact the answers to the above questions? For example, are there other industries that may impact production schedules or impact feed supplies?

\section{$\underline{\text { Toyo Tanso Answer }}$}

We are not worried about any other applications significantly affecting the nuclear material supply. Unexpected market changes could have a small impact in production however this would be expected to be short term and not affect any long term projects.

\section{$\underline{\text { SGL Answer }}$}

Not only is the US pursuing the HTR opportunity, but several other countries as well. Thus all global buyers of nuclear grade graphite would compete for the same raw materials and resources. All customers in this industry among other industries would require graphite and they all would be competing for similar raw materials and the same manufacturing resources.

Other industries which are major consumers of graphite and can have an impact on graphite availability, include steel, aluminum, batteries, photovoltaic's, LED, etc.

Question 11: How would changes to the fabrication process be evaluated and shown to produce graphite that is equivalent to that used in qualification experiments?

\section{$\underline{\text { Toyo Tanso Answer }}$}

Toyo Tanso has been producing stable graphite for many years and there have not been any significant variations such as changes in the coke brand in the same graphite grade.

If a production change is deemed necessary it is executed based on procedures that satisfy ISO-9001. The result of the process change is examined by three groups within Toyo Tanso (Production Division, Research \& Development Division and Quality Assurance Dept.) and steps are then taken to verify if the new procedure meets the requirements for the process change.

If it is determined that the process change could cause any influence on the quality more than deemed acceptable by the above groups the approval of the quality management groups and the customer are necessary.

If a customer does not approve the process change we continuously perform qualification examinations until desired results are obtained.

\section{$\underline{\text { SGL Answer }}$}

Whenever changes occur tests will need to be conducted to show the influence of the changes.

Subsequently a severity rating is determined and if there is an impact on the properties of the final product the customer will be informed from the occurrence to determination accordingly. 